UNIVERSIDADE ESTADUAL PAULISTA “JÚLIO DE MESQUITA FILHO”. FACULDADE DE CIÊNCIAS E TECNOLOGIA DE PRESIDENTE PRUDENTE PROGRAMA DE PÓS-GRADUAÇÃO EM GEOGRAFIA

\author{
Rosiane Morais Torrezan
}

Dissertação de Mestrado

\begin{abstract}
PROBLEMATIZAÇÃO DA SAÚDE PÚBLICA E AÇÃO EDUCATIVA NAS COMUNIDADES DO JARDIM MORADA DO SOL E PARQUE RESIDENCIAL FRANCISCO BELO GALINDO (PRESIDENTE PRUDENTEISP).
\end{abstract}

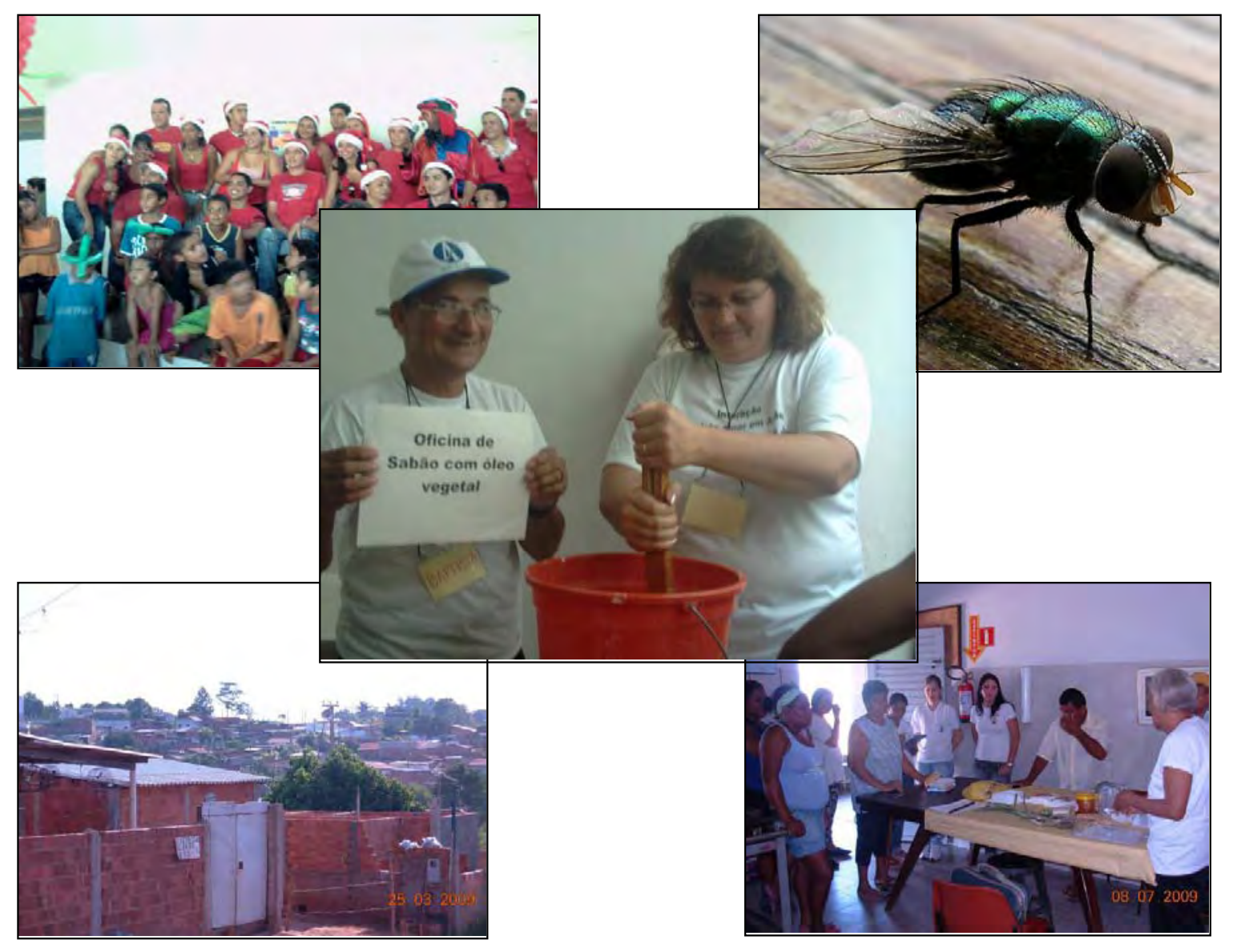

Presidente Prudente, SP 
UNIVERSIDADE ESTADUAL PAULISTA “JÚLIO DE MESQUITA FILHO”. FACULDADE DE CIÊNCIAS E TECNOLOGIA DE PRESIDENTE PRUDENTE

\title{
PROBLEMATIZAÇÃO DA SAÚDE PÚBLICA E AÇÃO EDUCATIVA NAS COMUNIDADES DO JARDIM MORADA DO SOL E PARQUE RESIDENCIAL FRANCISCO BELO GALINDO (PRESIDENTE PRUDENTE/SP).
}

\author{
ROSIANE MORAIS TORREZAN
}

Orientador: Prof. Dr. Raul Borges Guimarães

Co-Orientadora: Prof ${ }^{a}$.DR ${ }^{a}$. Maria Peregrina de FÁtima RotTa FurlanetTi

DisSERTAÇÃO
APRESENTADA AO PROGRAMA DE PÓS-
GRADUAÇÃO EM GEOGRAFIA DA
FACULDADE DE CIÊNCIAS E TECNOLOGIA
DA UNIVERSIDADE ESTADUAL PAULISTA
COMO REQUISITO PARCIAL PARA A
OBTENÇÃO DO TÍTULO DE MESTRE EM
GEOGRAFIA.


Torrezan, Rosiane Morais.

T649p Problematização da saúde pública e ação educativa nas comunidades do Jardim Morada do Sol e Parque Residencial Francisco Belo Galindo (Presidente Prudente/SP) / Rosiane Morais Torrezan. - Presidente Prudente: [s.n], 2009 $140 \mathrm{f}$. : il.

Dissertação (mestrado) - Universidade Estadual Paulista, Faculdade de Ciências e Tecnologia

Orientador: Raul Borges Guimarães

Co-orientadora: Maria Peregrina de Fátima Rotta Furlanetti

Banca: Antonio Cezar Leal, Márcia Siqueira de Carvalho Inclui bibliografia

1 Geografia da saúde. 2. Pesquisa-ação. 3. Educação em saúde. I. Autor. II. Universidade Estadual Paulista. Faculdade de Ciências e Tecnologia. III. Título.

CDD(18. ed.)370

Ficha catalográfica elaborada pela Seção Técnica de Aquisição e Tratamento da I nformação Serviço Técnico de Biblioteca e Documentação - UNESP, Câmpus de Presidente Prudente. 


\section{BANCA EXAMINADORA}

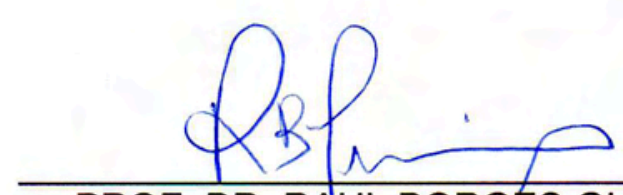

PROF. DR. RAUL BORGES GUIMARÃES Orientador (FCT/UNESP)<smiles>CCC</smiles>

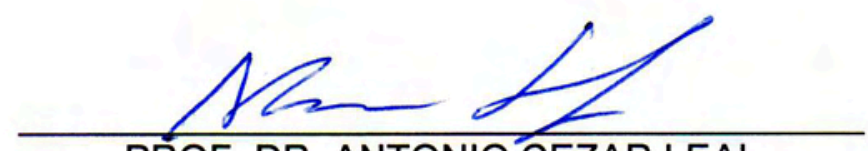

PROF. DR. ANTONIO CEZAR LEAL

(UNESP/FCT)
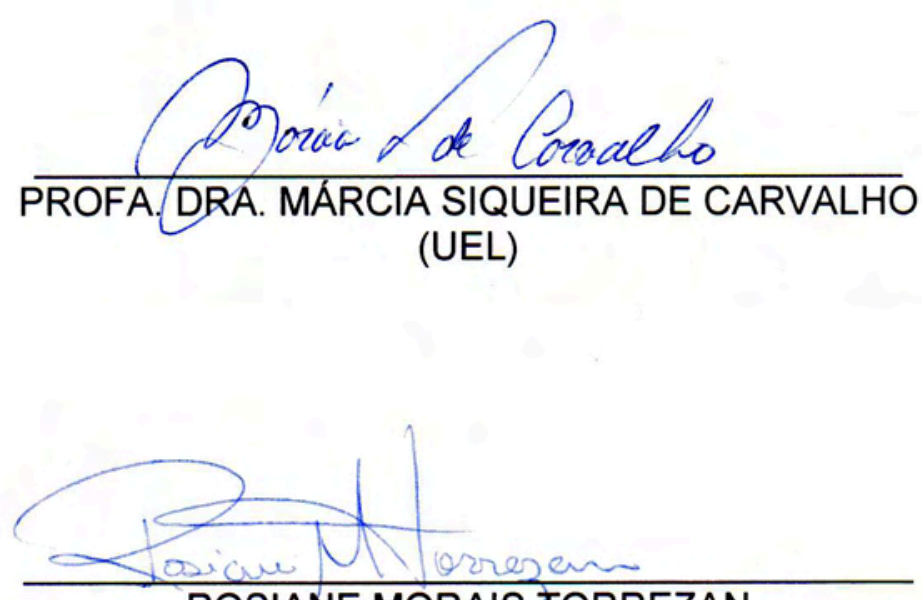

ROSIANE MORAIS TORREZAN

Presidente Prudente (SP), 14 de janeiro de 2010.

Faculdade de Ciências e Tecnologia

Rua Roberto Simonsen, 305 CEP 19060-900 Presidente Prudente SP

Tel 18 229-5352 fax 18 223-4519 posgrad@prudente.unesp.br 
DeDICo

AO MEU QUERIDO MARIDO, ROGÉRIO POR SER MEU AMADO, AMIGO, COMPANHEIRO

E ACREDITAR NA FORÇA DE UM SONHO

À MINHA FILHINHA ADORADA, VITÓRIA QUE DO ALTO DOS SEUS SEIS ANINHOS SOUBE COMPREENDER AS AUSÊNCIAS NECESSÁRI AS A ESTE ESTUDO

\section{Offereço}

AO MEU PAI FAUSTINO

PESQUISADOR NATO, EMBORA SEM TITULAÇÃO ACADÊMICA, DE QUEM HERDEI A CURI OSIDADE E O GOSTO PELO CONHECIMENTO CIENTÍFICO. POR ABSOLUTAMENTE TUDO. CORAÇÃO DE OURO, MEU PAI. 
Em primeiro lugar, a Deus, por permitir a convivência com tantas pessoas maravilhosas em minha história de vida. Dádiva divina, estas pessoas.

Dentre elas, minha família: meu pai Faustino, porto seguro em qualquer tormenta e em cujo amor incomensurável eu e minha filha nos refugiamos. À minha querida irmã Lúcia, pelo grande auxílio cuidando da Vitória com carinho e desprendimento. À minha mãe Odete, um constante aprendizado. Meu irmão Marcos, minha cunhada Deise e minhas sobrinhas, Beatriz e Giovana, e ao Beto, pelas palavras incentivadoras. Esteios que me ofereceram a estabilidade emocional fundamental.

Aos meus parentes de Águas de Lindóia: às minhas cunhadas Selma e Silvana (Dinda), e aos meus cunhados Jorge e Cláudio (Dindo), pelo carinho especial ofertado à Vitória. À minha sobrinha Marina, por cuidar com tanto amor e tão bem da Vi, quando eu me encontrava impedida de fazê-lo. Ao meu sogro e minha sogra, Mauro e Favorita, por todo o apoio, emocional e "logístico", dado ao meu marido durante a minha prolongada ausência para estudar.

Ao meu orientador, Professor Raul, agradeço imensamente por ter acreditado no potencial de uma professora do ensino público estadual, aceitando-me como aluna especial em sua disciplina, a partir da qual se iniciou minha trajetória na pós-graduação. Agradeço pela orientação precisa e permeada de sensibilidade, a partir de um olhar investigativo diferente e despido de pré-concepções - um inegável privilégio ser sua orientanda.

À minha co-orientadora, Professora Fátima Rotta, por ter me recebido de braços e coração abertos, pelas orientações e reflexões repletas de entusiasmo e alegria, direcionando assertivamente quando eu perdia o rumo nos trabalhos comunitários, e por descortinar para mim os caminhos de investigação de Paulo Freire, imbuídos de sonhos, esperança e deslumbramento. Outro inegável privilégio.

Ao Professor Cezar Leal, por ter gentilmente participado da banca de qualificação e de defesa, e nestas ocasiões ter realizado sugestões valiosas ao cumprimento do trabalho.

À Professora Márcia, por ter participado da banca de defesa e pelas observações pertinentes, propiciando oportunidade imprescindível de incremento qualitativo do texto final da dissertação. 
Aos funcionários da FCT/UNESP e da seção de pós-graduação, pelo apoio administrativo e institucional fundamentais à pesquisa.

Aos amigos de grande estima: Priscila e Xisto, Raquel, Natália e Ricardo (dos Santos). Por simplesmente serem do jeito que são: maravilhosos. Aos amigos do CEMESPP: Nice, Oséias (pelo mapa), Paula Lindo, Umberto, Gutierrez, Rafael (Rossi, eterno "noivo" da Vitória), Rafael Castro, Ricardo, Alexandre e Cláudia, pessoas admiráveis. Agradeço por tudo.

Aos amigos da pós-graduação, não menos importantes: Adriano Amaro, Sônia Segatti, Reginaldo, Maurício, Érica Ferreira, Ana Paula Camilo, Luciano Furini, Elaine Cícero, Maria Júlia, Natacha, Sandra, Márcio Catelan, Igor (pela correção generosa do resumo em francês): por todo o apoio das palavras certas, na hora certa.

Aos participantes da comunidade do Jardim Morada do Sol e Residencial Francisco Belo Galindo, por me permitirem aprender a ser uma educadora e por trabalharem incansavelmente na construção de nossa cidadania: "Seu" Braulino, Regina e Kadine, Rose, Maria José, Anamir,

Vanessa, Rosângela, Roselene, Miguel, Neia, Rosenalva, Neide. Aos que colaboraram permitindo a colocação das armadilhas de moscas em suas casas: "Seu" Domingos e Luíza; Rose e Angelim; Jorge; D. Elza; D. Eva e Isabel. À Tereza, pelos bolinhos inesquecíveis após as reuniões nas tardes frias de inverno. À D. Mazília e Sr. José, por se disporem a ensinar a fazer os remédios caseiros.

Ao Rogério, meu marido, por me incentivar, desde sempre, a estudar. Amigo, amoroso, paciente, ponderado, solícito - uma pessoa única, inigualável. À Vitorinha, luz da minha existência, por entender de forma tão amadurecida para os seus poucos aninhos, a necessidade que a mamãe tem de estudar.

$\mathrm{E}$, finalmente, ao CNPq, pelo apoio financeiro, sem o qual este trabalho seria impossibilitado. 
NI NGUÉM

Ninguém é tão forte, que nunca tenha chorado. Ninguém é tão fraco, que nunca tenha vencido. Ninguém é tão suficiente, para nunca ser ajudado. Ninguém é tão inválido, que nunca tenha contribuído. Ninguém é tão sábio, que nunca tenha errado. Ninguém é tão corajoso, que nunca teve medo. Ninguém é tão medroso, que nunca teve coragem.

Ninguém é tão alguém, que nunca precisou de ninguém.

Equipe de Bethânia Parque Residencial Francisco Belo Galindo 


\section{RESUMO}

Nesta pesquisa realizou-se uma reflexão acerca da ação educativa em saúde junto a uma comunidade local, problematizando as condições de saúde em áreas urbanas periféricas pobres. O ponto de partida para isto foi o acompanhamento do trabalho que vem sendo realizado pelo Laboratório de Geografia da Saúde da FCT/UNESP de Presidente Prudente sobre o monitoramento das principais espécies de moscas domésticas. A observação desta experiência permitiu compreender: 1. A relação saúde e ambiente, considerando a forma de propagação de vetores; 2. A etiologia da mosca doméstica e suas correlações com agentes patogênicos; 3. O processo de aprendizagem que este estudo exige para estudantes de geografia; 4. O vínculo da universidade com a comunidade e os serviços de saúde e educação das áreas de estudo. A partir do diálogo e das discussões sobre as moscas domésticas, procurou-se analisar a experiência de articulação de atores sociais na resolução dos problemas de saúde da sua própria comunidade, a fim de promover a educação em saúde e ainda propor uma estratégia de educação em saúde, contribuindo com a integração dos sistemas de saúde, educação, sócio-sanitário e de conservação ambiental. O presente trabalho é resultado deste processo. Trata-se, portanto, de uma pesquisaação que associa formas de ação coletiva orientadas para a resolução de problemas ou de objetivos de transformação da realidade, ancorada no referencial da Educação Popular em Saúde. O trabalho junto à comunidade foi efetivado em parceria com o projeto de Desenvolvimento Local implementado pelo Senac de Presidente Prudente, com a colaboração da Casa da Sopa e demais parceiros; e possuindo como eixo primordial o diálogo entre saberes e sujeitos; partindo da realidade concreta vivenciada por eles. A análise dos dados foi feita por meio de descrição compreensiva, utilizando-se de recursos da análise de discurso e outros que permitiram apreender a diversidade de sentidos de vida presentes nesse processo educativo. Inicia-se esta dissertação situando-se a investigação no contexto de vida pessoal, profissional e acadêmica da pesquisadora. Em seguida, apresentam-se os pressupostos teórico-metodológicos que nortearam a pesquisa. Depois, parte-se para a descrição da observação participante que acompanhou o monitoramento das principais espécies de moscas domésticas. Descrevem-se as discussões e as ações comunitárias relativas à educação em saúde. Procede-se a uma reflexão acerca das teorias, métodos e ações empregadas na pesquisa. Ao final, procura-se apontar alguns aspectos do que se pode apreender nesta investigação, acerca dos processos educativos comunitários em saúde.

Palavras-chave: Geografia da saúde. Pesquisa-ação. Educação em saúde. 


\section{[RESUME.}

Dans cette recherche, on a prévu une réflexion sur l'action éducative en santé près d'une communauté locale, en problématisant les conditions de la santé dans les aires urbaines pauvres. Pour cela, on a réalisé un diagnostique de la situation épidémiologique de l'aire, à travers de l'observation participante et de l'accompagnement du monitorage des principales espèces de mouches domestiques, travail réalisé au sein du Laboratoire de Géographie de la Santé de la FCT/UNESP à Presidente Prudente. L'observation a permis de comprendre : 1. Le rapport santéenvironnement, considérant la forme de propagation des vecteurs ; 2. L'étiologie de la mouche domestique et ses relations réciproques avec les agents pathogéniques ; 3 . Le processus d'apprentissage de cette étude pour les étudiants de Géographie ; 4. Le lien de l'Université avec la communauté et les services de santé et d'éducation dans les aires d'étude. À partir de cela, on a l'objective d'analyser l'expérience d'articulation des acteurs sociaux dans la résolution des problèmes de la santé de sa propre communauté pour promouvoir l'éducation en santé et aussi proposer une stratégie d'éducation en santé, dans les sens de faire l'intégration des systèmes de santé, d'éducation, socio-sanitaire et de conservation environnementale. Il s'agit, pour autant, d'une recherche-action qui associe les formes d'action collective orientées à la résolution des problèmes ou bien aux objectifs de transformation de la réalité, ancrés sur l'idée de l’Éducation Populaire en Santé. Le travail avec la communauté a été réalisé en partenariat avec le projet Développement Local, exécuté par le SENAC de Presidente Prudente avec la collaboration de la Casa da Sopa comme avec d'autres partenaires ; l'axe primordial, c'est le dialogue entre les savoirs et les sujets à partir de la réalité concrète qu'ils vivent. L'analyse des données a été faite par une description compréhensive, avec des recours d'analyse du discours, parmi d'autres, ce qui a permis de saisir la diversité des sens de vie présents dans ce processus éducatif. Cette dissertation commence par la recherche du contexte de vie personnel, professionnel et académique de la chercheuse. Ensuite, on présente les présupposés théorico-méthodologiques qui ont orienté la recherche. Puis, c'est la description de l'observation participante et l'accompagnement du monitorage des principales espèces de mouches domestiques ; on décrie les discussions et las actions communautaires relatives à l'éducation en santé ; on réfléchie à partir des théories, méthodes et actions employés dans la recherche. À la fin, on essaie de montrer quelques aspects appris à partir de la recherche, considérant les processus éducatifs communautaires en santé.

MOTS-CLÉS: Géographie de la santé.Recherche-action. Éducation en santé. 


\section{SUMÁRIO}

ÍNDICE 10

LISTA DE FIGURAS 12

LISTA DE FOTOS 12

LISTA DE QUADROS 13

RESUMO 7

RESUME 8

APRESENTAÇÃO 14

INTRODUÇÃO 18

CAPÍtUlo 1. PRESSUPOSTOS TEÓRICO-METODOLÓGICOS 25

CAPÍTULO 2. DIÁLOGOS SOBRE MOSCAS DOMÉSTICAS: PONTO DE PARTIDA DA PROBLEMATIZAÇÃO 48

CAPÍTUlO 3. PESQUISA - AÇÃO - AÇÃO EDUCATIVA EM SAÚDE. 64

CAPÍTULO 4. DISCUTINDO OS CAMINHOS DA SAÚDE PÚBLICA NOS BAIRROS 101

5. À GUISA DE CONCLUSÃO 120

6. BIBLIOGRAFIA 128 ANEXOS 136 


\section{ÍNDICE}

AGRADECIMENTOS
EPÍGRAFE _.
RESUMO
RESUME
APRESENTAÇÃO.

CAPITUlO 1. PRESSUPOSTOS TEÓRICO-METODOLÓGICOS

1. FUNDAMENTAÇÃO TEÓRICO-METODOLÓGICA

1.1. A EduCaÇÃo em SaÚde, A Pesquisa Participante E a Contribuição da CiÊnCia GEOGRÁFICA. 26

1.2. ESTADO, CAPITALISMO E TRABALHO: O DOMÍNIO SOBRE O CORPO E A SAÚDE. 28

1.3. OS SABERES MÉDICOS E AS POLÍTICAS PÚBLICAS DE EDUCAÇÃO E SAÚDE. 30

1.4. O ENSINO FORMAL NO BRASIL E A EDUCAÇÃO EM SAÚDE.

1.5. A EDUCAÇÃO NÃO-FORMAL, A CIÊNCIA GEOGRÁFICA E A PESQUISA QUALITATIVA EM SAÚDE.

CAPítulo 2. DiÁlOgOS SOBRE MOSCAS DOMÉSTICAS: PONTO DE PARTIDA DA PROBLEMATIZAÇÃO .

2.1. PESQUiSA COM MOSCAS DOMÉSTICAS, SAÚDE E AMBIENTE 50

FAMÍLIA MUSCIDAE (ESPÉCIE MUSCA DOMESTICA) 53

FAMÍLIA CALLIPHORIDAE (ESPÉCIES CHRYSOMYA MEGACEPHALA, C. ALBICEPS E C. PUTORIA)

RESULTADOS OBTIDOS NO LABORATÓRIO DE GEOGRAFIA DA SAÚDE. 58

2.2. O INTERESSE DA COMUNIDADE PELA PESQUISA E O INÍCIO DA AÇÃO EDUCATIVA 60

Capítulo 3. PesquisA-AÇÃo: AÇão edUCATIVA EM SAÚDE. 
3.1. O SENAC E A CASA DA SOPA

3.2. PRIMEIROS PASSOS PARA O DIÁlOGO: O MUTIRÃO DE LIMPEZA.

3.3. O COLÓQUIO: AS MOSCAS EM EVIDÊNCIA.

3.4. O QUESTIONÁRIO: UMA CONSTRUÇÃO COLETIVA.

3.5. A BUSCA DO DIÁLOGO NA TENTATIVA DE DERRUBAR BARREIRAS: A ESCOLA E O PSF 84

3.6. A SARNA, O PIOLHO E A AÇÃO EDUCATIVA. 90

A $1^{\mathrm{a}}$ OFICINA: EDUCAÇÃO PARA A SAÚDE AMBIENTAL. 92

A $2^{\mathrm{a}}$ OFICINA - ENSINANDO NA EMEIF. 96

A 3 OFICINA: A POMADA E O XAROPE “DA VOVÓ”. 99

CAPÍTULO 4. DISCUTINDO OS CAMINHOS DA SAÚDE PÚBLICA NOS BAIRROS

101

4.1. O PROGRAMA SAÚDE DA FAMÍLIA

4.2. BUSCANDO A INTERAÇÃO NECESSÁRIA

4.3. ENTRE A TEORIA E A REALIDADE: O BAIRRO COMO ESPAÇO DE IDENTIDADE

115

5. À GUISA DE CONCLUSÃO

6. BIBLIOGRAFIA. 


\section{LISTA DE FIGURAS}

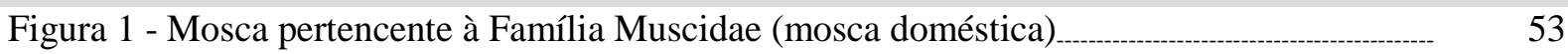

Figura 2 - Mosca pertencente à Família Muscidae (mosca doméstica)

Figura 3 - Ciclo biológico da mosca doméstica

Figura 4 - Mosca da Família Calliphoridae (Chrysomya albiceps) _ 56

Figura 5 - Mosca da Família Calliphoridae (Chrysomia megacephala) ___ 57

Figura 6 - Mosca da Família Calliphoridae (Chrysomya putoria) 57

Figura 7 - Número de moscas no Jd. Morada do Sol_a 59

Figura 8 - Dinâmica populacional de moscas

Figura 9 - Mapa com legenda desenhado por morador 67

Figura 10 - Mapa com legenda desenhado por morador _tan 67

\section{LISTA DE FOTOS}

Foto 1 - Reunião de Desenvolvimento Local

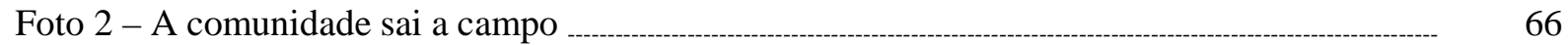

Foto 3 - Casa da Sopa Francisco de Assis - Jd. M. do Sol 70

Foto 4 - Confraternização: Reunião de Desenvolvimento Local _.._ 72

Foto 5 - Reunião de Desenvolvimento Local _____ 72

Foto 6 - Centro de Referência da Assistência Social - CRAS _ 75

Foto 7 - O Colóquio _-_ 81

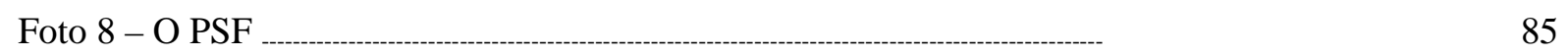

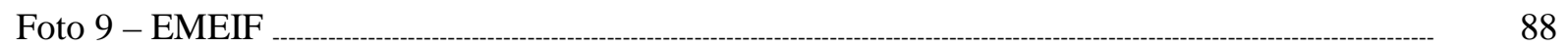

Foto 10 - O PSF visto da frente do portão da EMEIF ___ 89

Foto 11 - Fazendo o sabão

Foto 12 - Fazendo o xampu 95

Foto 13 - Participação da comunidade

Foto $14-2^{\mathrm{a}}$ Oficina _-1_- 96

Foto 15 - Participação da equipe escolar

Foto 16 - Mexendo o sabão _-_ 98

Foto 17 - O sabão _-_ 99

Foto $18-3^{\text {a }}$ Oficina _-__- 99

Foto 19 - Aprendendo sobre as ervas 100 
Quadro 1 - Roteiro-base dos itens da observação participante

Quadro 2 - Pesquisa-ação

Quadro 3 - Reuniões de Desenvolvimento Local 73

Quadro 4 - Outras atividades realizadas 74

Quadro 5 - Oficina - Interação entre sujeitos, saberes e fazeres. 91

Quadro 6 - Sistematização dos tipos ideais de educação em saúde 103 


\section{APRESENTAÇÃo.}

“A ‘verdade’ nos elementos da narrativa não adquire tanta importância, não são os fatos em si, mas os significados dos fatos é que contam.”

SILVA, 2008, p.18

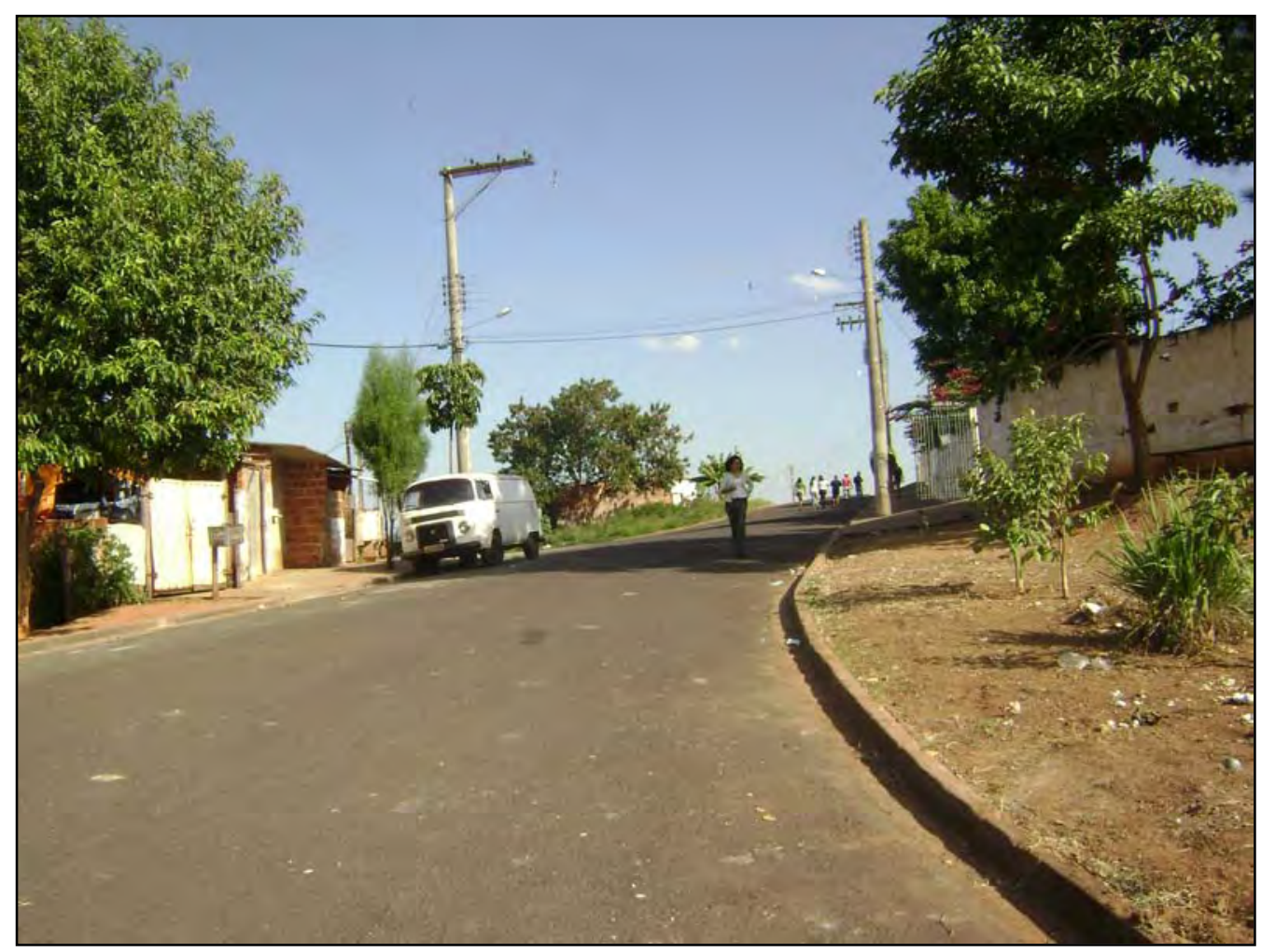

RUA WILLIAM EDY TEDROS, JD. MORADA DO SOL - 2008 


\section{UM PROJeto de VidA.}

Peço licença ao leitor desta dissertação para contar uma história. A história de uma experiência - na verdade, várias delas, porque uma experiência não existe sozinha, ela está sempre relacionada com as outras que a cercam.

O meu retorno à Presidente Prudente não significou apenas uma mera locomoção no espaço geográfico, em um tempo específico: representou o reencontro com um lugar que era meu - e eu sempre o considerei assim porque este lugar esteve (e ainda está) imbuído de diversos símbolos e lembranças que compõem a minha história, marcos identitários materiais e imateriais cujas presenças fazem com que eu me sinta “em casa”: o bairro e a casinha onde eu nasci (e onde moro novamente agora), a igreja que freqüentei (com a praça em frente, na qual brincava), a escola onde estudei (e para a qual retornei como professora), o campus da FCT/UNESP (boas lembranças da época da graduação), as tardes mornas desta cidade. O “cheiro de verde” que invade as ruas no verão, as frutas da região - a carambola, a cajamanga, a pinha, o tamarindo que na cidade onde eu fui morar as pessoas nunca nem tinham ouvido falar.

Significou voltar às raízes, reencontrar familiares, amigos queridos de há muito, vários deles que também voltavam felizes após muitas andanças...

Foi um retorno profícuo, também, aos estudos e à Universidade - a FCT, meus professores da graduação: o Miguel Gimenez (abraço caloroso no reencontro, sempre com palavras de incentivo); o Raul (que me aceitou como aluna especial em sua disciplina "Saúde, Ambiente e Desenvolvimento” na pós-graduação, experiência fundamental para a redefinição de meu interesse de estudo); a Carminha (orientadora maravilhosa no bacharelado, que orientou de maneira cuidadosa mais do que minha monografia, mas também minha conduta profissional e muitos aspectos da minha vida); o Thomaz (recepção entusiasmada, generosidade amiga). Profissionais renomados, eu sei bem, mas o que prevalece é o fato de continuarem a ser as pessoas fantásticas que sempre admirei, e que me passaram uma sensação especial: a de acolhimento.

No entanto, voltar a Presidente Prudente significou, sobretudo, sair de Águas de Lindóia, uma estância turística hidromineral situada, como os próprios lindoienses gostam de frisar, “nos contrafortes da Serra da Mantiqueira”, região de Campinas, São Paulo, Brasil; cidade natal do meu marido e minha cidade durante treze anos, desde o término da graduação. Foi lá que iniciei e vivi fases importantes da minha vida: a profissional, como professora do ensino público estadual; e a pessoal, como mulher casada e, posteriormente, mãe de família. E mais: os laços familiares e de amizade construídos; os alunos aos quais me afeiçoei; a nossa casa, que 
financiamos "naquele sacrifício", acreditando que vale tudo para ter um teto (especialmente em uma cidade turística, onde a especulação imobiliária chega às raias do absurdo) - tudo isto fez com que as raízes crescessem fortes e vigorosas lá, também, e deixar tudo foi muito difícil.

Mas aconteceu um projeto de estudo. Ele nasceu de uma convicção minha, e que a prática de muitos anos como professora corroborou: a de que não é possível uma prática docente de qualidade sem pesquisa. Embora eu tenha buscado esta união durante toda a minha experiência profissional, trabalhando sempre projetos de pesquisa com meus alunos, chegou o momento em que foi preciso buscar na Universidade o aprimoramento teórico-metodológico necessário à continuidade desta prática. O projeto de pesquisa que eu tencionava implementar juntamente com meus alunos acabou transformado, então, em projeto de mestrado. E que depois, na aula magna do mestrado do Programa de Pós-Graduação em Geografia da FCT/UNESP em agosto de 2007, a fala sensata do Prof. Eliseu descortinou a verdade: o que existia, realmente, não era meramente um projeto de mestrado, mas um projeto de vida.

E... Uma bolsa de estudos. Fundamental para implementar este projeto de vida, porque reingressar ao mundo acadêmico após quatorze anos imersa no ensino público e em seus incontáveis problemas, não é tarefa fácil. A bolsa do CNPq, oferecida pelo Programa aos quatro primeiros colocados no processo seletivo em suas linhas de pesquisa, foi aceita com alegria, e proporcionou o mergulho necessário nos estudos e na vivência cotidiana no CEMESPP e no Laboratório de Geografia da Saúde. Vivência esta que possibilitou a reinserção nas atividades de pesquisa, agora efetivadas numa dimensão que eu desconhecia, visto que não se davam em tal proporção à época da minha graduação. As pesquisas integradas de agora, dentro dos grupos, e em alguns casos, pesquisas que se dão integradas até mesmo entre estes grupos, lançam desafios científicos e de investigação a âmbitos anteriormente ignorados, considerados até mesmo inalcançáveis. Isto porque relacionam-se à áreas do conhecimento de difícil intersecção, mas que a prática e a persistência dos pesquisadores pertencentes aos diversos grupos de pesquisa demonstraram ser possíveis. Estas pesquisas desenvolvem-se em perspectivas multiescalares, de forma multi e interdisciplinar, trazendo resultados interessantes e inéditos.

É o caso da pesquisa a ser descrita neste relatório, ligada às experiências investigativas do laboratório de Geografia da Saúde e do CEMESPP, sob a orientação do Prof. Dr. Raul Borges Guimarães, envolvendo exclusão sócio-espacial, políticas públicas, moscas domésticas, saúde pública e educação. Abraçamos a empreitada e, no seu decorrer, a pesquisa acabou por envolver também comunidade, piolho, sarna, cachorro, criança e população. E, se não bastasse esse imbróglio, terminou por envolver muito, também, de diálogo, simpatia, confiança, humildade, sensibilidade, respeito... E amor. E tudo isso misturado com Geografia. 
Inadmissível? Impossível? Talvez. Só existe um jeito de saber: é fazer. E nós fizemos: eu, meu orientador, a comunidade, o Senac, as crianças, as professoras, a população. Juntos. E, conforme nos ensina sabiamente Paulo Freire (2005), o mais importante: em co-laboração.

Convido o leitor a descobrir esta empreitada, tendo paciência para ler esta dissertação até o fim. E sirvo-me novamente de Paulo Freire (2005, p.25), para dizer:

Entre estes (leitores) ${ }^{1}$, haverá, talvez, os que não ultrapassarão suas primeiras páginas. Uns, por considerarem a nossa posição, diante do problema da libertação dos homens, como uma posição idealista a mais, quando não um 'blábláblá' reacionário. 'Blábláblá' de quem se 'perde' falando em vocação ontológica, em amor, em diálogo, em esperança, em humildade, em sim-patia. Outros, por não quererem ou não poderem aceitar as críticas e a denúncia que fazemos da situação opressora, situação em que os opressores se 'gratificam', através de sua falsa generosidade.

Os que, não obstante, se dispuserem a ultrapassar as primeiras páginas, não se arrependerão. Os caminhos de pesquisa aqui traçados ainda não terminaram, porque constituem processos em permanente mutação, mas ensejam resultados, no mínimo, intrigantes. O que para uma pesquisa não deixa de ser interessante, já que um de seus objetivos primordiais é jamais encerrar-se em si mesma, mas sim, e principalmente, proporcionar novas e amplas indagações a respeito de seus possíveis desdobramentos.

\footnotetext{
${ }^{1}$ Parêntesis nosso.
} 


\section{INTRODUÇÃO}

Nesta pesquisa pretendeu-se efetivar uma ação educativa em saúde junto a uma comunidade local, problematizando as condições de saúde em áreas urbanas periféricas pobres. Para tanto, foi realizado um diagnóstico da situação epidemiológica nestas áreas, através do acompanhamento do monitoramento das principais espécies de moscas domésticas, trabalho realizado pelo grupo de pesquisa do Laboratório de Geografia da Saúde da FCT/UNESP de Presidente Prudente. Nossa pesquisa, portanto, tem como principais objetivos a compreensão da importância da ação educativa na implementação da política pública de saúde, além da análise da experiência de articulação de atores sociais para a resolução dos problemas de saúde da sua própria comunidade. Pretendeu-se, com isto, construir juntamente com a comunidade uma estratégia de educação em saúde, no sentido da integração dos sistemas de saúde, de educação, sócio-sanitário e de conservação ambiental.

No primeiro capítulo encontram-se os pressupostos teórico-metodológicos que nortearam a pesquisa, bem como os objetivos, a relevância e as justificativas acerca do estudo efetivado. Trata-se de uma pesquisa-ação que associa formas de ação coletiva orientadas para a resolução de problemas ou de objetivos de transformação da realidade, ancorada no referencial da Educação Popular em Saúde.

No segundo capítulo, está descrita a primeira etapa da pesquisa: realizada através da metodologia da pesquisa-participante, no acompanhamento da pesquisa do Laboratório de Geografia da Saúde da FCT/UNESP de Presidente Prudente sobre a infestação por moscas em bairros localizados em porções centrais e periféricas da malha urbana, permitindo uma comparação entre eles ${ }^{2}$. A observação permitiu compreender: 1 . A relação saúde e ambiente, considerando a forma de propagação de vetores; 2. A etiologia da mosca doméstica e suas correlações com agentes patogênicos; 3. O processo de aprendizagem que o estudo desse objeto exige para estudantes de graduação em geografia; 4. O vínculo da universidade com a comunidade e os serviços de saúde e educação das áreas de estudo. Os bairros periféricos estudados foram o Jardim Morada do Sol e o Parque Residencial Francisco Belo Galindo, adjacentes, e nos quais a pesquisa sobre as moscas originou uma demanda pela ação educativa em saúde, a ser descrita no terceiro capítulo ${ }^{3}$.

\footnotetext{
${ }^{2}$ Este estudo ainda encontra-se em andamento, devendo ser concluído em 2010.

${ }^{3} \mathrm{O}$ trabalho de educação em saúde junto à comunidade tem sido efetivado em parceria com o projeto de Desenvolvimento Local implementado pelo Senac de Presidente Prudente, com a colaboração da Casa da Sopa e demais parceiros; e possuindo como eixo primordial o diálogo entre saberes e sujeitos; partindo da realidade concreta vivenciada por eles.
} 
Procura-se, portanto, no terceiro capítulo, dar um panorama das atividades educativas em saúde que tem ocorrido na comunidade, mas o texto escrito é limitado. As palavras impressas, às vezes tão libertadoras, em alguns casos encerram. Fica difícil apreender o convívio, a comunicação, a vivência e a experiência colhidas. Não se ouvem as vozes, não se enxergam as expressões dos rostos, perdem-se os olhares. Pode-se ler o que foi dito, mas não se pode saber a entonação com que foi dito; as emoções não têm muito lugar nos textos científicos. Só que esta pesquisa fala sobre coisas que são vivas, e por mais que haja um esforço em descrevê-las com eficácia, serão fatos que já aconteceram, reinterpretados e contados do ponto de vista do pesquisador, e reinterpretados novamente pelo leitor ao lê-las. Mas as reinterpretações de tudo o que foi visto e ouvido, vivido e analisado não serão vãs, se em tudo isto for possível enxergar a vida por meio das impressões e do diálogo, como ensina Freire (1987, p. 79): “se é dizendo a palavra com que, 'pronunciando' o mundo, os homens o transformam, o diálogo se impõe como caminho pelo qual os homens ganham significação enquanto homens”.

O quarto capítulo é o das reflexões acerca do que se estudou, do que se viu, presenciou e do que se viveu. É o momento de analisar as perdas e ganhos, os erros e os acertos, avaliar os caminhos trilhados, contabilizar o aprendizado. E deles não tirar conclusões, mas considerações: lições, que podem servir ou não, e que podem também não serem seguidas à risca, e serem modificadas de acordo com as circunstâncias, mas que levem à reflexão.

O ciclo da vida não se fecha, não se conclui, está sempre recomeçando: então, como pode uma pesquisa cujas pessoas ainda vivem, assim como suas ações ainda se manifestam, apresentar conclusões definitivas? Na verdade, cada leitor terá as suas, ainda que não sejam decisivas, baseadas não apenas no que leu, mas no que viveu e presenciou, e em suas memórias. Ainda mais porque, conforme nos ensina Bosi (1994, apud MELO, 2008), o passado não ressurge no presente por um processo espontâneo, mas está sempre atrelado a acontecimentos e eventos presentes.

\section{O TEMA DA PESQUISA: RELEVÂNCIA E JUSTIFICATIVAS.}

O presente projeto de pesquisa surgiu da necessidade de se problematizar as condições de saúde em áreas urbanas periféricas pobres, considerando a distribuição e difusão de moscas domésticas. Nosso objetivo inicial foi, portanto, realizar um diagnóstico da situação epidemiológica relativa ao monitoramento das principais espécies de moscas domésticas em um bairro localizado em área periférica urbana na cidade de Presidente Prudente, SP; bem como efetivar uma ação educativa em saúde, junto à comunidade local. 
A pesquisa encontra-se inserida em um projeto coletivo do Laboratório de Geografia da Saúde. Este laboratório visa reunir os estudos do CEMESPP (Centro de Estudos e Mapeamento da Exclusão Social para Políticas Públicas - grupo interdepartamental da FCT/UNESP) que correlacionam padrões espaciais das condições de vida de pessoas expostas a processos excludentes, assim como correlacionar estes padrões com as formas de organização dos serviços de saúde.

Há muito sabemos que saúde e doença são processos históricos e sociais determinados pelo modo como cada sociedade vive, se organiza e se produz.

Hipócrates, médico grego considerado o pai da medicina e por alguns o primeiro epidemiologista, ao publicar sua famosa obra Dos Ares, Das Águas e Dos Lugares (em aproximadamente 480 a.C.), já demonstrava a relação dos fatores ambientais com o surgimento das doenças.

Ele avaliava a saúde e a doença como resultado das variações entre os humores do corpo, representados pelo fogo (coração), ar (pituitária/cérebro), terra (bile amarela) e água (bile negra do estômago), cujos desequilíbrios estariam diretamente ligadas aos processos sócionaturais e aos miasmas (emanações) do ambiente.

Esse foi o primeiro esforço sistemático para apresentar as relações causais entre fatores do meio físico e doença e, por mais de dois mil anos, o terreno teórico para a compreensão das doenças endêmicas e epidêmicas. Ainda nesta obra, Hipócrates reconhecia a presença contínua de certas doenças que chamou de endêmicas, e outras nem sempre presentes, mas que por vezes aumentavam em demasia, às quais denominou epidêmicas, sendo estes dois termos, ainda hoje, utilizados pelos profissionais de saúde (LEMOS e LIMA, 2002).

O higienismo foi um outro movimento que fortaleceu a compreensão social da doença, a partir de meados do século XIX. A partir desse século, com os intensos impactos do processo de industrialização e urbanização sobre as condições sanitárias e de saúde, esses problemas passaram a ser vistos como resultados de processos políticos e sociais. Mas com o advento do paradigma microbiano essa relação foi reduzida aos problemas de saneamento e ao controle de vetores, ficando a dimensão social e política esquecida (FREITAS, 2003).

Segundo a ótica higienista, os agentes etiológicos (micróbios) têm que ser destruídos pela intervenção sanitária. Mas a partir das décadas de 1930 e 1950, começa novamente a prevalecer o conceito de multicausalidade, reiterando as relações produzidas pelos diferentes intervenientes (meio, agente, hospedeiro). Retorna-se, com isso, ao pensamento hipocrático, porque propõe-se uma abordagem integrada e globalizante (LEMOS e LIMA, 2002). 
Por sua vez, os avanços científicos e tecnológicos recentemente alcançados no campo da saúde fizeram surgir a falsa idéia de que a maioria das doenças, em especial as infectocontagiosas e parasitárias, estariam sob controle e poderiam deixar de constituir um problema de saúde pública. O uso em larga escala de inseticidas químicos a partir da década de 50 , tanto no meio rural quanto no meio urbano, trouxe a esperança de que o homem poderia se ver livre das doenças transmitidas por insetos, vetores biológicos dos mais diversos agentes patogênicos de enfermidades que afetam o homem e também os animais domésticos.

Infelizmente, não só o controle químico revelou-se ineficiente, uma vez que o uso exclusivo de praguicidas provoca o desenvolvimento da resistência aos inseticidas químicos, além de impactar o ambiente, contaminando o solo, a água e os alimentos; como esses insetos passaram a encontrar no ambiente urbano, principalmente nas áreas periféricas degradadas, condições extremamente favoráveis ao seu pleno desenvolvimento.

Na atualidade, está estabelecido que para melhor entender-se o processo saúde-doença em qualquer comunidade, faz-se necessário entender o ser humano no seu meio físico, biológico, social e econômico. Estes meios são considerados como fatores determinantes e condicionantes deste processo, estabelecendo a ocorrência e a prevalência das doenças infecto-parasitárias nas paisagens terrestres (LEMOS e LIMA, 2002). Desse modo, os problemas de saúde, sua valoração social e gravidade irão se distribuir desigualmente, entre mulheres e homens, brancos, negros, amarelos e indígenas, pobres e ricos, jovens e velhos, seja pelas diferentes origens sociais, pela desigualdade de acesso às ações e serviços de saúde e demais políticas sociais, em meio a processos muitas vezes contraditórios, em permanente mudança.

Considerados na sua dimensão coletiva, fica claro que a superação dos problemas de saúde vai além das decisões de âmbito hospitalar ou de assistência médica. Seu enfrentamento necessita do trabalho conjunto e interdisciplinar, com ênfase na promoção da saúde e na prevenção de doenças e outros agravos, quais sejam a gravidez precoce e a violência, através da ação intersetorial e da integração do sistema educacional, sociossanitário e de conservação ambiental. Tendo em vista que saúde e ambiente deteriorados não derivam somente de equívocos científicos e/ou tecnológicos, os sistemas e regimes sócio-econômicos e políticos de nossas sociedades desiguais são os responsáveis pela situação.

Assim, a falta de articulação e investimentos adequados em educação, saúde pública e saneamento têm provocado o reaparecimento de doenças como a tuberculose, a hanseníase, a cólera, a febre amarela, a dengue e a meningite meningocócica e diversas doenças infectoparasitárias, todos problemas de saúde pública onde o papel da educação preventiva é crucial. Por esta razão, a educação para a saúde torna-se de fundamental importância, tendo em vista que 
constitui um universo de ações que podem atuar no sentido de atenuar ou agravar o quadro de desigualdades sociais e exclusão. Isto sem falar no poder transformador que uma educação reflexiva, participativa e voltada ao desenvolvimento da cidadania pode acarretar. Deve-se ter em vista que a educação em saúde pode e deve utilizar-se de metodologias que instiguem o indivíduo a assumir a responsabilidade por sua própria saúde e pela saúde da coletividade, desenvolvendo aptidões para sua participação construtiva na comunidade, bem como a ter consciência crítica sobre o papel do Estado na promoção da saúde (ver MACIÁ ANTÓN, 2000; GENTILI, 2001; GHEDIN e PIMENTA, 2002).

É aí que se insere a presente pesquisa. Cabe indagar qual é o âmbito da ação educativa. Em que medida a educação impõe-se como uma agenda relevante da política de saúde brasileira?

\section{OBJETIVOS DA PESQUISA.}

A pesquisa teve como principal objetivo a problematização das condições de saúde em áreas urbanas periféricas pobres, a partir da experiência de uma ação educativa em saúde junto a uma comunidade local.

Para tanto, foi realizado o acompanhamento do monitoramento das principais espécies de moscas domésticas nestas áreas (Jardim Morada do Sol e Parque Residencial Francisco Belo Galindo), trabalho realizado pelo grupo de pesquisa do Laboratório de Geografia da Saúde da FCT/UNESP de Presidente Prudente.

Nossa pesquisa em também entre seus principais objetivos a compreensão da importância da ação educativa na implementação da política pública de saúde, além da análise da experiência de articulação de atores sociais para a resolução dos problemas de saúde da sua própria comunidade. Pretendeu-se, com isto, construir juntamente com a comunidade uma estratégia de educação em saúde, no sentido da integração dos sistemas de saúde, de educação, sócio-sanitário e de conservação ambiental.

O Jardim Morada do Sol e o Parque Residencial Francisco Belo Galindo ${ }^{4}$ contam com 780 casas e encontram-se distantes sete quilômetros da área central, motivo pelo qual os moradores sentem um isolamento com relação ao centro da cidade.

Inicialmente, as famílias foram colocadas no bairro Jardim Morada do Sol de forma precária por um programa municipal de desfavelamento. Hoje, os bairros vêm passando por transformações significativas, possuindo asfalto, rede elétrica, água tratada, escola, programa saúde da família e centro de referência da assistência social.

\footnotetext{
${ }^{4}$ Dados do PSF (Programa Saúde da Família) de abril de 2009.
} 


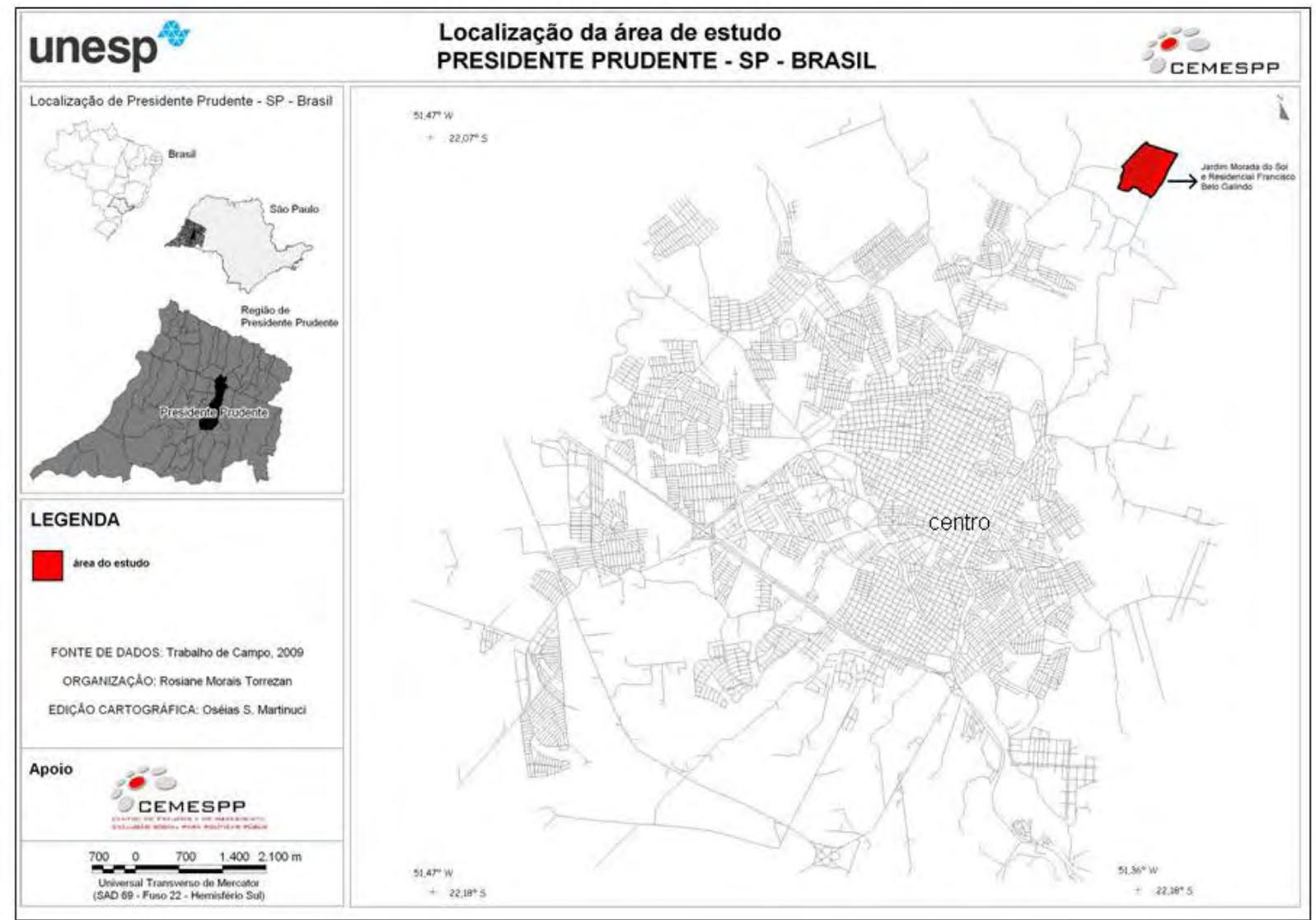

Dos 2.330 habitantes:

- 229 possuem mais de 60 anos;

- 711 são crianças (0 a 14 anos);

- 216 são adolescentes (15 a 19 anos).

E ainda:

- 1151 são do sexo masculino;

- 1179 são do sexo feminino.

Segundo levantamento realizado pelos próprios moradores em abril de 2009, existem no Jd. Morada do Sol:

- 30 terrenos baldios;

- 22 construções inacabadas;

- 8 barracos de madeira;

- 6 construções de um cômodo. 
No Parque Residencial Francisco Belo Galindo, os moradores identificaram a existência de 30 barracos de madeira.

Em seu entorno localizam-se pequenas propriedades rurais (chácaras e sítios), caracterizados pela agricultura de subsistência.

Nosso plano de ação constituiu-se, portanto, de: reuniões com a comunidade com a finalidade de socializar os resultados da pesquisa com as moscas; discussão com as pessoas (líderes comunitários e religiosos, diretores de escola, agentes de saúde e outros) a respeito dos problemas de saúde relacionados à infestação do bairro por moscas; planejamento das ações educativas idealizadas pelo grupo; planejamento das ações políticas, fruto das demandas da comunidade por maior atenção do poder público com relação aos serviços urbanos (como uma maior freqüência da coleta de lixo), aos serviços de saúde e infra-estrutura urbana; realização das ações educativas planejadas em conjunto com a comunidade.

Para sustentar a investigação optamos, enquanto método de análise, pelo uso da pesquisa-ação, uma vez que segue uma linha de pesquisa associada a formas de ação coletiva que é orientada em função da resolução de problemas ou de objetivos de transformação, além de empreender uma busca de compreensão e de interação entre pesquisadores e membros das situações investigadas. Trata-se de um tipo de pesquisa social com base empírica realizada com a estreita associação com uma ação ou com a resolução de um problema coletivo, no qual os pesquisadores e os participantes representativos da situação estão envolvidos de modo cooperativo ou participativo. Uma pesquisa pode ser qualificada de pesquisa-ação quando houver realmente uma ação por parte das pessoas implicadas no problema sob observação, e os pesquisadores, por sua vez, desempenham um papel ativo no equacionamento dos problemas encontrados, no acompanhamento e na avaliação das ações desencadeadas em função dos problemas. Mas a pesquisa não deve limitar-se a uma forma de ação, sob o risco de incorrer em ativismo: ela deve aumentar o conhecimento dos pesquisadores e o conhecimento ou o "nível de consciência” das pessoas e grupos considerados (THIOLLENT, 1988).

Como se trata de um trabalho de caráter contínuo pretende-se realizar, posteriormente, uma avaliação mais acurada do seu impacto na realidade e na problemática abordada. Para isso, serão repetidos os procedimentos de análise e coleta pelo grupo de pesquisa do Laboratório de Geografia (com a colocação das armadilhas nos mesmos pontos), para que se possa avaliar os resultados obtidos com a educação em saúde. Este trabalho deverá ser concluído no ano de 2010. 


\section{CAPÍtulo 1. Pressupostos TeÓRICO-MEtOdOlÓgicos.}

“O que faz a diferença no trabalho é o envolvimento, o toque humano, o carinho de fazer junto. Não aquela coisa feita por obrigação, impessoal. É o olhar, o acolhimento.”

R., moradora.

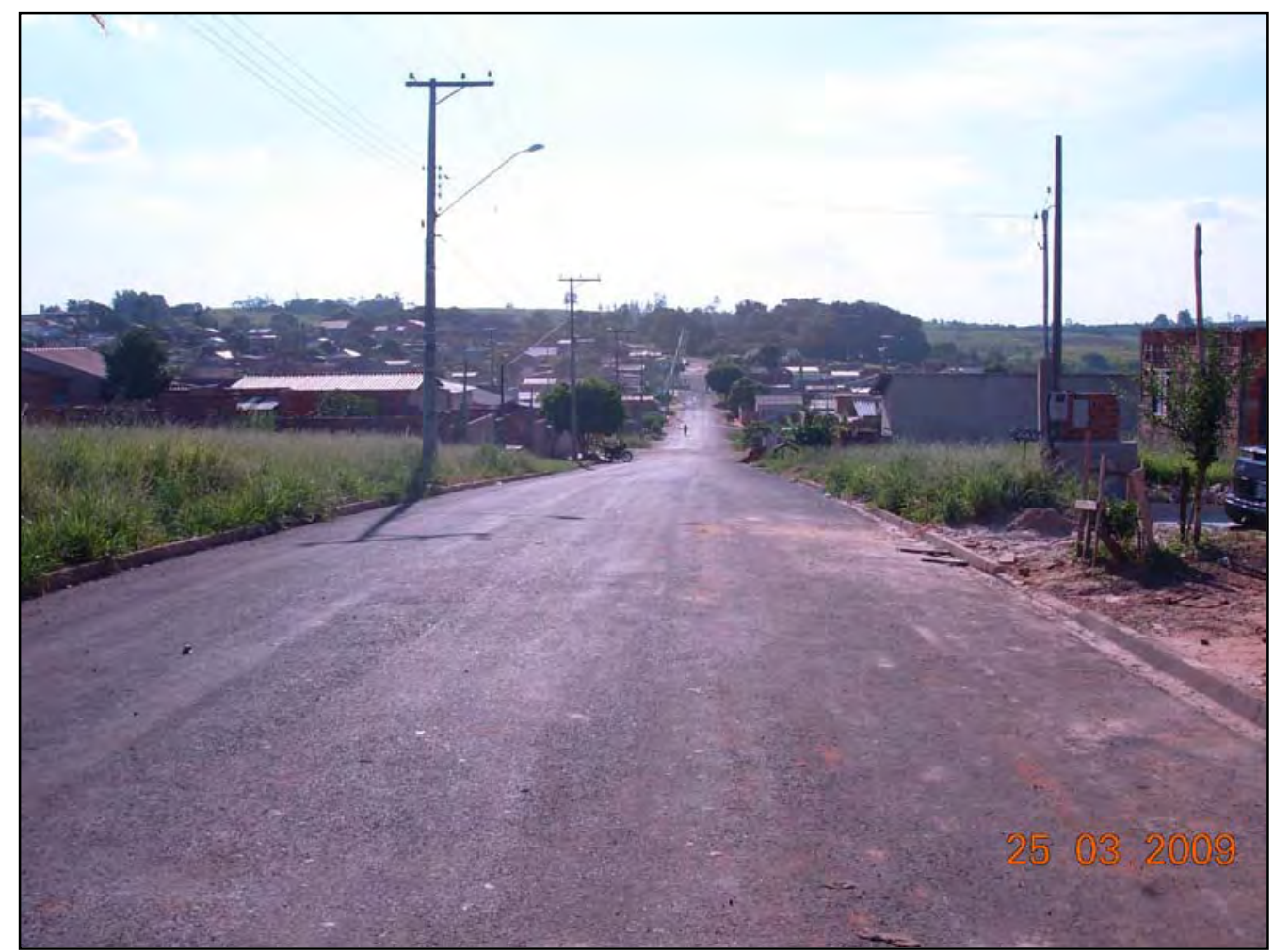

RUA ISMAEL DA CRUZ - RESIDENCIAL FRANCISCO BELO GALINDO - 2009 AUTORA: TORREZAN, R. M. 


\section{FUNDAMENTAÇÃO TEÓRICO-METODOLÓGICA.}

\subsection{A EDUCAÇão EM SAÚde, A PESQUiSA PARTICIPANTE E A CONTRIBUiÇão dA CIÊNCIA GEOGRÁFICA.}

Ao falarmos sobre os temas saúde educação, não podemos deixar de considerar o contexto da realidade concreta atual, onde estas duas dimensões ligadas ao desenvolvimento social e, por que não dizer, humano, ocorrem.

Nas últimas décadas, a recessão de algumas economias desenvolvidas causou transtornos econômicos que modificaram as perspectivas mundiais, aumentando consideravelmente o número de pessoas que vivem abaixo do nível de pobreza, calculadas em cerca de um terço da população mundial. Estudos demonstraram que em alguns países, apesar do aumento do PIB, não foi diminuído o nível de pobreza absoluta.

Foi grande o impulso tomado pela urbanização a partir do pleno desenvolvimento da industrialização. Com o crescimento das cidades, surgiram os chamados "problemas urbanos": falta de coleta de lixo, ausência de rede de água e de esgoto, ruas estreitas, poluição, moradias insalubres, etc. Segundo o autor, contudo, estes problemas não eram da cidade; eram do próprio modo de produção capitalista, e se manifestavam na cidade. Isto se concretizou (a nível urbano) em padrões e áreas residenciais bem diversificadas, e também nas possibilidades de acesso às melhorias e infra-estruturas urbanas. Nesse contexto, a parcela da população excluída se "aloja” (não habita) nas áreas urbanas periféricas. Deve-se considerar, ainda, que os problemas urbanos só existem para a parcela da população que não dispõe de recursos para amenizá-los, e nesse caso, caberia ao poder público fazê-lo (LEFÈBVRE, 2001).

Nesse ambiente urbano, sem acesso aos empregos, bens e serviços essenciais, a população empobrece e observa a degradação de suas condições de existência. A cidade torna-se, assim, criadora da pobreza, que se manifesta de forma mais cruel e impiedosa para os habitantes da periferia e dos cortiços (SANTOS, 1993).

Estas desigualdades espaciais, traduzidas na crescente periferização das cidades, nada mais são do que frutos das contradições sociais engendradas pelo modo capitalista de produção. Seguindo essa linha de raciocínio, veremos que os problemas urbanos acabam inevitavelmente por constituírem-se em problemas ambientais, que são, simultaneamente, problemas de saúde.

Em resposta a isso, tem-se, no âmbito governamental, a formulação de políticas públicas de saúde e educação, cujas propostas de ação e formação de profissionais da área apontam para uma visão integralizada, com uma maior preocupação com o meio ambiente, e dentro de uma perspectiva ético-ecológica; e para um modelo de atenção à saúde voltada para a melhoria da qualidade de vida da população. Contudo, novas e prementes demandas sociais relacionadas à 
saúde tornam inadiável o alcance de novo patamar de desenvolvimento no que concerne a este setor.

A atual estratégia de desenvolvimento do capitalismo global atua de maneira perversa, perpetuando a miséria para grande parte da população mundial através das distorções dos mecanismos econômicos empregados para acelerar o crescimento da produção. E não se avista no horizonte nenhuma perspectiva de alteração desse quadro. Ao contrário das décadas de 1960 e 1970, em que as Nações Unidas e as Organizações Internacionais alardeavam intenções desenvolvimentistas para as áreas do capitalismo periférico, nos dias atuais não se tem nem ao menos um vago movimento nesse sentido.

O empobrecimento galopante de vastos contingentes populacionais repercute diretamente no setor de saúde. Nas zonas urbanas e rurais dos países periféricos os índices de morbidade e mortalidade são devidos às condições precaríssimas de moradia, saneamento básico e alimentação; além da total falta de noções básicas de higiene causada pelos índices muito baixos de escolaridade e informação.

Evidentemente, nas zonas urbanas estes problemas se concentram, tornando-se mais nítidos. Além da dieta insuficiente, os quadros da pobreza urbana incluem a promiscuidade nas habitações insalubres, a violência, a dissolução das famílias, o trabalho em condições desumanas e o desemprego crônico.

São estas realidades que recairão sob a responsabilidade dos serviços públicos, em especial dos que tratamos aqui: os de saúde, educação e assistência social, com uma demanda tal que chega a tomar proporções de crise.

A falta de articulação e investimentos adequados em educação, saúde pública e saneamento têm provocado o reaparecimento de doenças como a tuberculose, a hanseníase, a cólera, a febre amarela, a dengue e a meningite meningocócica, sem falar nas DST, gravidez precoce e na violência, todos problemas de saúde pública onde o papel do poder público é crucial.

Tudo isso exige o esforço coordenado do Estado e da sociedade civil em políticas de inclusão social, organização do espaço urbano, habitação, alimentação e educação, além de saneamento, qualidade da água, condições das ruas e coleta de lixo. Tudo contribui (ou não) para uma vida saudável. 


\subsection{ESTADO, CAPITALISMO E TRABALHO: O DOMÍNIO SOBRE O CORPO E A SAÚDE.}

O Estado capitalista está inegavelmente vinculado aos donos do capital. Sendo assim, o capital e o Estado são agentes da organização do espaço. Daí falar-se em espaço do capital.

A ação do capital, por sua vez, não é uniforme, quer em termos temporais ou espaciais. Mas a grande corporação capitalista tem constantemente que ampliar sua lucratividade, mesmo onde as condições para tal ampliação não existem. Ela exerce, então o seu poder, pressionando o Estado a investir criando estas condições. Ao Estado, portanto, o qual se encontra vinculado com o capital e os interesses dominantes e suas corporações, caberá a construção de toda a infraestrutura necessária à reprodução do capital, criando, dessa forma, o espaço capital. Por isso, o Estado age de forma desigual, espacialmente falando (CORRÊA, 1986).

E foi assim desde a gênese do capitalismo. Segundo Hobsbawm (1977), as regiões que se encontravam fora do “coração” do desenvolvimento capitalista, e que entraram em contato com as potências européias ou sofreram sua influência foram transformadas em economias dependentes e colônias do Ocidente. Enquanto boa parte das Américas era transformada em economias escravagistas para atender às necessidades do capitalismo europeu, e extensas regiões da África eram forçadas a caminhar para trás economicamente devido ao tráfico de escravos; por razões semelhantes, grandes áreas da Europa Oriental reduziram-se a economias neofeudais. E, indo pelo mesmo caminho, o pequeno desenvolvimento agrícola comercial e da produção manufatureira estimulado pelas potências européias em algumas áreas esparsas foi interrompido pela deliberada desindustrialização das colônias e semi-colônias, assim que sua produção ameaçou competir com a da matriz colonial. Assim:

O efeito final da ascensão do capitalismo europeu foi, portanto, intensificar o desenvolvimento desigual e dividir o mundo cada vez mais nitidamente em dois setores: o ‘desenvolvido’ e o ‘subdesenvolvido', em outras palavras, o explorador e o explorado. O triunfo do capitalismo no final do séc. XVIII selou essa evolução. O capitalismo, que sem dúvida proporcionou as condições históricas para a transformação econômica em toda parte, de fato dificultou ainda mais as coisas para os países que não pertenciam ao núcleo original de desenvolvimento capitalista, ou não eram seus vizinhos imediatos (HOBSBAWM, 1977, p.174).

Estado e capitalismo operam em conjunto, conforme Harvey (1992), para garantir que as regras básicas do modo capitalista de produção continuem a operar como forças plasmadoras do 
desenvolvimento histórico-geográfico. Isto porque a celebrada "mão invisível” do mercado, de Adam Smith, nunca foi suficiente para garantir um crescimento estável ao capitalismo. É necessário algum grau de ação coletiva, qual seja a regulamentação e a intervenção do Estado para compensar as falhas de mercado (tais como danos ambientais), evitar excessivas concentrações de poder de mercado, combater o monopólio, fornecer bens coletivos (infraestruturas sociais e física, tais como defesa, educação) que não podem ser produzidos e vendidos pelo mercado e impedir falhas descontroladas decorrentes de surtos especulativos.

David Harvey (1992) diz que, na prática, as pressões coletivas exercidas pelo Estado e por outras instituições aliadas ao poder de domínio do mercado pelas grandes corporações e outras instituições igualmente poderosas, tais como as religiosas, políticas, sindicais, patronais e culturais (e, porque não acrescentar, as educacionais), afetam de modo vital a dinâmica do capitalismo.

O Estado, entretanto, não é uno, centralizador e “sem face”, pairando autoritariamente sobre a sociedade. Ele é o instrumento específico de um sistema de poderes que o ultrapassa e o complementa. Não se deve, contudo, proceder a uma "fetichização" do Estado (considerando o Estado em si), mas os fatos atinentes ao espaço devem ser relacionados a toda a vida social e, conseqüentemente, a todas as formas de poder aí geradas (CLAVAL, 1979).

Para Foucault (1979), tampouco existe “O” poder. O que existe são práticas ou relações de poder, que se disseminam por toda a estrutura social. É preciso considerar que nem todas as formas de poder são destrutivas, repressoras, excludentes. Algumas de suas formas possuem uma eficácia produtiva, uma riqueza estratégica, uma positividade. E é justamente este aspecto que tem como alvo o corpo humano, não para supliciá-lo, mutilá-lo, mas para aprimorá-lo, adestrá-lo. Sendo assim, não se explica inteiramente o poder por sua função repressiva: ele não quer expulsar os homens da vida social, e sim controlá-los e utilizá-los ao máximo, aproveitando suas potencialidades e capacidades. Consegue, então, atingir dois objetivos: torna os homens produtivos e reduz sua capacidade de revolta, transformando-os em seres “úteis” e “dóceis”.

O Estado, contudo, não fica de fora nesta questão. Ele é chamado para contribuir na preparação da massa de trabalhadores através da educação, e da manutenção da saúde. Mas ele o faz agindo de acordo com os interesses dos poderes hegemônicos.

Nesse sentido, a análise genealógica de Foucault visa a distinguir as grandes transformações do sistema estatal, as mudanças de regime político ao nível dos mecanismos gerais e dos efeitos de conjunto e a mecânica de poder que se expande por toda a sociedade, assumindo as formas mais regionais e concretas, investindo em instituições, tomando corpo em técnicas de dominação. Poder este que intervém materialmente, atingindo a realidade mais 
concreta dos indivíduos - o seu corpo - e que se situa ao nível do próprio corpo social, e não acima dele, penetrando na vida cotidiana e por isso podendo ser caracterizado como micro-poder ou sub-poder.

Portanto, a saúde dos indivíduos encontra-se subordinada às diversas instâncias de poder, das quais é lícito afirmar que o Estado constitui uma das mais importantes. Isto porque o Estado possui uma esfera de ação demasiadamente ampla, influindo nas questões de controle sobre os corpos das pessoas e suas vidas, tais como: trabalho, educação, saúde, moradia, lazer, mobilidade, liberdade, e outros. Uma aparente valorização da educação acaba por, na realidade, responsabilizar os indivíduos pela sua própria formação e qualificação, em função de objetivos mercadológicos que pouco ou nada têm a ver com seu desenvolvimento pessoal e intelectual numa dimensão crítica e emancipatória. Seu papel como formador dos profissionais de saúde e educação, e a subordinação do desenvolvimento destes saberes às forças hegemônicas não pode ser negligenciada, embora as ações da sociedade civil organizada e instituições e entidades de apoio tenham desempenhado, ao longo da história, papel decisivo na alteração dos paradigmas e nas transformações dos setores historicamente controlados pelo Estado, como veremos mais adiante, com a contextualização do caso brasileiro.

\subsection{OS SABERES MÉDICOS E AS POLÍTICAS PÚBLICAS DE EDUCAÇÃo EM SAÚDE.}

Ainda nos primeiros anos da República iniciou-se no Brasil um movimento de educação na área da saúde, a fim de convencer a população a mudar tradicionais hábitos anti-higiênicos que facilitavam a disseminação de doenças infecto-contagiosas. Um dos recursos usados era a divulgação de cartazes e panfletos elaborados pelo Ministério da Educação e Saúde e pelos servidores estaduais (BERTOLLI FILHO, 1996).

Os movimentos em prol da especialização sanitária, que ocorriam desde a década de 1920, deram origem a propostas de criação de escolas e serviços especializados em saúde pública. Carlos Chagas, Afrânio Peixoto, João de Barros Barreto e José Paranhos Fontenelle no Rio de Janeiro; Geraldo Horácio de Paula Souza, Francisco Borges Vieira e Samuel Pessoa em São Paulo: estes sanitaristas e pesquisadores de sólida formação humanista formam o elo em que teve início o ensino da saúde pública e a progressiva institucionalização do campo, que culminou com a criação de instituições como a Escola Nacional de Saúde Pública em Manguinhos - Rio de Janeiro, e a Faculdade de Saúde Pública da USP - São Paulo (SANTOS E FARIA, 2006).

Ao longo desse processo, entretanto, as organizações produtivas hegemônicas influenciaram o trabalho em saúde e, conseqüentemente, influenciaram na formação desse 
profissional. O taylorismo e o fordismo preconizavam a divisão e a especialização estanque do trabalho e do trabalhador, que realizava tarefas repetitivas maquinalmente. No caso da saúde, isso resultou na divisão do trabalho prático e intelectual, que cabia apenas ao médico.

No entanto, o espaço das escolas não foi utilizado, uma vez que grande parte da população brasileira se encontrava fora delas; e continuava analfabeta, sem poder beneficiar-se desse material. Por isso, desde 1938 as mensagens higienistas passaram a ser divulgadas pelas emissoras de rádio existentes em todos os estados. Ganharam impulso também os cursos de formação de enfermeiras sanitárias, cuja missão era percorrer os bairros mais carentes, ensinando aos moradores as regras básicas de higiene e encaminhando os doentes mais graves para os hospitais públicos ou filantrópicos (BERTOLLI FILHO, 1996).

A partir da instalação do Estado Novo, a administração sanitária criou serviços especiais de educação em saúde. Eles criaram cartazes e folhetos que chamavam a atenção pelas ilustrações coloridas, e podiam ser entendidas mesmo pelas pessoas que não sabiam ler.

Durante a era Vargas (1930-1945), o campo da saúde no Brasil foi moldado pelo novo Ministério da Educação e Saúde Pública (Mesp), criado em 1931, e que imprimiu uma tônica mais urbana às políticas. Criaram-se novos cursos de especialização em saúde pública, já que esta era uma base importante de sua política social (SANTOS E FARIA, 2006).

Na segunda metade dos anos 70, procurou-se consolidar o processo de expansão da cobertura assistencial, em atendimento às proposições formuladas pela OMS na Conferência Alma-Ata (1978), que preconizava “Saúde para Todos no ano 2000”, principalmente por meio da Atenção Primária à Saúde. Nessa mesma época começa o Movimento da Reforma Sanitária Brasileira, constituído inicialmente por uma parcela da intelectualidade universitária e dos profissionais da área da saúde. Posteriormente, incorporaram-se ao movimento outros segmentos da sociedade, como centrais sindicais, movimentos populares de saúde e alguns parlamentares. As proposições desse movimento, iniciado em pleno regime autoritário da ditadura militar, eram dirigidas basicamente à construção de uma nova política de saúde efetivamente democrática, considerando a descentralização, universalização e unificação como elementos essenciais para a reforma do setor.

A $8^{a}$ Conferência Nacional da Saúde, realizada em março de 1986, considerada um marco histórico, consagra os princípios preconizados pelo Movimento da Reforma Sanitária. Em 1987, é implementado o Sistema Unificado e Descentralizado de Saúde (SUDS), como uma consolidação das Ações Integradas de Saúde (AIS), que adota como diretrizes a universalização e a eqüidade, o acesso aos serviços, a integralidade dos cuidados, a regionalização dos serviços de saúde e implementação de distritos sanitários, a descentralização das ações de saúde, o 
desenvolvimento de instituições colegiadas gestoras e o desenvolvimento de uma política de recursos humanos.

O capítulo dedicado à saúde na nova Constituição Federal, promulgada em outubro de 1988, retrata o resultado de todo o processo desenvolvido ao longo dessas duas décadas, criando o Sistema Único de Saúde (SUS) e determinando que "a saúde é direito de todos e dever do Estado” (art.196). No contexto destas mudanças, em 1991 foi criado o Programa Nacional de Agentes Comunitários de Saúde (Pnacs), que institucionalizou uma série de experiências de educação em saúde de todo o país. Mais tarde, em 1992, o Pnacs foi transformado no Programa de Agentes Comunitários de Saúde, o Pacs (MOROSINI et al, 2007).

No início, o Pacs focalizou a atenção à gestante e à criança. Posteriormente, com a entrada da cólera no país, o programa passou a dar mais ênfase aos procedimentos relacionados ao controle e à prevenção dessa doença. A partir de 1994, alicerçado no sucesso do Pacs, o Programa Saúde da Família (PSF) começa a formar suas primeiras equipes incorporando e ampliando a atuação dos Agentes Comunitários de Saúde (ACS). Mais tarde, o Pacs incorporouse ao PSF e sua expansão passou a estar vinculada a esse programa que, por prever uma equipe formada por médico, enfermeiro, auxiliar de enfermagem e ACS, é considerado um projeto mais adequado. O Pacs passou a ser uma estratégia transitória até o estabelecimento das condições para a implantação de um PSF. Juntos, Pacs e PSF compreendem a Estratégia Saúde da Família, um conjunto de diretrizes, instrumentos e esforços articulados para viabilizar a reformulação da atenção à saúde a partir da atenção básica no marco do Sistema Único de Saúde, o SUS (MOROSINI et al, 2007). Esta tendência de fortalecimento da atenção básica e da ação educativa em saúde está gerando novos desafios, como a capacitação profissional e a articulação de diferentes espaços de trabalho (a UBS -Unidade Básica de Saúde, a escola, etc.). Entretanto, Barroso (2005) afirma que o conceito de saúde permanece, ainda, sob o modelo "médicohegemônico", baseado numa organização "hospitalocêntrica” da assistência médica, na sofisticação tecnológica, na exacerbação da demanda espontânea e no privilegiamento do saber clínico.O que ocorre no Brasil atualmente, segundo Teixeira, Paim e Vilasbôas (1998, apud BARROSO, 2005), é uma disputa entre modelos assistenciais que apontam para a reprodução dos modelos hegemônicos Médico assistencial-privativista e assistencial sanitarista.

Segundo Dupret (s/d), as transformações verificadas nas últimas décadas, determinadas pela velocidade dos avanços tecnológicos, têm interferido diretamente na forma de organização dos processos de trabalho em saúde, impondo grandes desafios em relação à formação dos trabalhadores desta área, para desenvolverem ações de promoção e proteção à saúde, como estratégia de transformação das práticas sanitárias do país. A incorporação de novas tecnologias 
tem implicado no surgimento de novos serviços e ocupações, no aumento da produtividade e na busca de maior qualificação profissional para corresponderem eficaz e eficientemente às diversas demandas nos diferentes setores que integram a sua atuação. O trabalho torna-se cada vez mais complexo, com mais autonomia; cada vez mais coletivo e intelectualizado, exigindo dos trabalhadores capacidade de diagnóstico, além de solucionar problemas, tomar decisões, interferir no processo de trabalho e sobretudo trabalhar em equipe; o trabalhador deve ainda possuir a capacidade de auto organizar-se e de enfrentar criativamente situações de constantes mudanças.

A mesma autora destaca também que, ao mesmo tempo, as doenças infecciosas e parasitárias no Brasil vêm apresentando modificações em seu padrão de ocorrência, assinalando alterações importantes no processo de adoecimento e morte das populações. Apesar do decréscimo nos indicadores de mortalidade, as taxas de incidência de grande parte das endemias continuam estáveis ou até mesmo ascendentes, ocorrência esta que aponta para um novo complexo de condicionantes e determinantes sócio-ambientais, os quais alteram significativamente o impacto das ações de controle sobre esses agravos. O surgimento de novas doenças do porte das Arboviroses, Doenças Hemorrágicas, Aids, HTLV, dentre outras, e a manutenção ou ressurgimento de outras desse grupo - malária, hepatite, leishmaniose, chagas - , estão associadas ao aumento da exposição aos agentes patógenos provocados por fatores que vão desde a ocupação inadequada e uso desordenado do espaço urbano-rural; à deterioração das condições de vida; ao aumento do intercâmbio de populações; à crescente resistência dos parasitos aos quimioterápicos; às alterações ambientais importantes, quais sejam, a poluição atmosférica, os desmatamentos, a introdução de tecnologias sujas e de microorganismos geneticamente alterados; e até a indefinição recente dos papéis institucionais nos processos de descentralização de ações.

Nesse cenário, a educação assume papel estratégico - no sentido de buscar alternativas pedagógicas inovadoras que priorizem a formação ampla do trabalhador e do cidadão comprometido não só com a promoção da saúde, como também com a promoção do bem-estar social; e ofereça instrumentos de trabalho compatíveis com a realidade dos serviços em nível local, para garantir impacto positivo na qualidade de vida da população.

Atualmente, mais de 200 mil ACS (Agentes Comunitários de Saúde) estão em formação - em sala de aula ou em vias de começar o curso - pelas escolas técnicas do SUS em todo o país, num processo induzido financeiramente pelo Ministério da Saúde. Os cursos de formação técnica dos ACS ficam a cargo das Escolas Técnicas do SUS (Etsus) e dos Centros Formadores de Recursos Humanos em Saúde (Cefor). São 36 instituições de formação distribuídas pelo Brasil. 
Tratam-se de escolas públicas, voltadas para a área de saúde, ligadas em sua maioria às secretarias de saúde de Estados e Municípios, cuja principal atribuição é ordenar, orientar e participar da qualificação profissional em saúde (MOROSINI et al, 2007).

Com isto, é possível constatar a importância do poder público nesse setor: cabe a ele a implementação das políticas voltadas à saúde pública, a institucionalização dos serviços e, ainda, a formação dos profissionais, bem como definir a sua distribuição espacial.

\subsection{O ENSINO FORMAL NO BRASIL E A EDUCAÇÃo EM SAÚDE.}

Já dissemos anteriormente que tanto o Estado quanto a escola são instituições de poder, embora atuando em níveis diferentes, desempenhando funções diferentes ao longo da história.

O capitalismo contemporâneo cria uma crescente acumulação de formas espaciais superpostas, sendo que a organização espacial do presente impacta sobre o futuro: é o que Milton Santos chama de inércia dinâmica. Ainda segundo o autor, para entender a evolução da totalidade social espacializada, tem-se que entender de que forma os homens organizam sua sociedade no espaço, e como a concepção e o uso que o homem faz do espaço sofrem mudanças. Muitas formas construídas no passado pela sociedade acabam por constituir capital fixo, desempenhando certas funções ainda importantes para ela (possuem, portanto, força de inércia). Estas formas podem ainda, adaptar-se a novas funções exigidas pela estrutura vigente. Assim, o moderno (a nova função), e o antigo (a forma), podem estar juntos, ao lado de funções e formas contemporâneas, tornando complexa a organização espacial (SANTOS, 1985).

A educação formal brasileira constitui um bom exemplo de como isto ocorre. As primeiras escolas surgidas no Brasil foram implantadas pelos padres jesuítas, com a finalidade de sujeitar os índios, facilitando o trabalho de conquista e dominação dos brancos europeus. Os jesuítas estavam a serviço do rei e do papa, e deviam defender seus negócios na colônia. A educação escolar no Brasil surge, portanto, completamente a serviço dos interesses hegemônicos. Tanto é assim que, quando os jesuítas começaram a agir de forma independente, indo contra as necessidades e determinações dos impérios colonialistas, em 1759 foram expulsos (PILETTI, 1991).

Segundo Casimiro (2006), para entender a educação naquele contexto, deve-se levar em conta o modo como se constituiu o sistema social. Tanto em Portugal como em suas colônias, todas as decisões de caráter religioso dependiam do Rei em virtude do instituto do 'Padroado' que conferia ao monarca o lugar de chefe da Igreja - direito esse identificado com os 'direitos' de conquista, determinando o caráter evangelizador e colonizador do Brasil e direcionando o 
modelo cultural e educacional. Os agentes da religião católica estiveram sempre (como parte mais importante daquela sociedade), obrigando, punindo, doutrinando e educando, permeando todas as camadas sociais, infiltrando-se na vida material e espiritual do povo, de forma obrigatória e com justificativas legais, políticas e espirituais.

As Constituições Primeiras do Arcebispado da Bahia, promulgadas em 1707 pelo Arcebispo Dom Sebastião Monteiro da Vide, foram as diretrizes administrativas, jurídicas, ideológicas e educacionais que confirmaram e legitimaram todo um sistema de poder imposto pelo Estado, cujo Rei comandava a Igreja. As Constituições demonstram, em todo o seu teor, uma inequívoca opção pela defesa dos direitos dos portugueses e seus descendentes brancos, em detrimento dos direitos dos índios, negros ou cristãos-novos (judeus ou filhos de judeus convertidos). Isto tanto no que diz respeito à escravidão e às suas conseqüências sociais, tanto quanto aos direitos e deveres do clero e dos fiéis ou, ainda, quanto à imposição de modelos educacionais, atitudes e comportamentos considerados 'adequados' ou 'inadequados' à conduta social (CASIMIRO, 2006).

Ainda segundo a mesma autora, a ideologia religiosa amorteceu os conflitos sociais latentes e doutrinou os escravos para a obediência aos senhores, mediante ameaças de castigos divinos, promessas de obtenção de indulgências plenárias e vida celestial. No plano normativo, funcionou através das constituições eclesiásticas em vigor, e do conceito de 'direito divino'; entretanto, com uma concepção de justiça diferenciada, caso se tratasse do senhor ou caso se tratasse do escravo. Na prática, agiu como aparelho repressor, temido e eficiente, diante dos atributos do Tribunal do Santo Ofício, sediado na Metrópole (CASIMIRO, 2006).

A mentalidade portuguesa arraigada como autoconsciência de povo 'eleito', de 'arautos da fé', reforçada pelas alianças com Roma e pela militância das ordens religiosas, sobretudo a jesuítica, marcou o pensamento dominante e a educação da sociedade colonial. Na época, acreditava-se piamente que ao índio 'selvagem', ao negro 'inferior' e ao judeu de 'sangue impuro' antepunha-se sempre, "pela vontade suprema de Deus, o português de raça 'pura', cristão e ‘eleito’, portanto, o único e justo merecedor das terras conquistadas, de benefícios materiais e de lugar diferenciado na sociedade, nas escolas, na Igreja e no 'reino dos céus'” (CASIMIRO, 2006, p. 4).

Portanto, Igreja e Estado exerceram conjuntamente ação de sujeição ideológica e educativa. Censurando livros, proibindo veículos de imprensa e manipulando as idéias dos textos clássicos, enfim, 'ocultando o saber' e mantendo a ignorância, através da Mesa de Consciência e Ordens, incutiam nas consciências noções de pecado, para mascarar os conflitos sociais e para reforçar o sistema jurídico. Assim, ao lado dos crimes de sedição, desobediência civil, lesa-majestade etc., 
foram acrescentados os pecados correspondentes, de cunho religioso. De acordo com CASIMIRO (2006),

no que diz respeito à educação, no sentido lato, desse período, podemos dizer que a Igreja tomou a si o papel principal, oferecendo oportunidades desiguais, manifestando preconceitos e justificando-os, em nome do Evangelho. Uma parcela de brancos freqüentava os colégios e podiam, alguns, fidalgos, ir completar os seus estudos no Reino. Para outros, que faziam parte da maioria da população, os não-brancos, ela proporcionou apenas os rudimentos das primeiras letras, o ensino profissionalizante, a catequese e a cristianização. Documentos nos mostram toda uma legislação eclesiástica discriminando os negros, os índios e os cristãos-novos, para a vida religiosa e, decorrentemente, para a educação, como observamos, por exemplo, nas diligências que se deviam fazer sobre os candidatos à vida religiosa, contidas nas determinações das Constituições Primeiras do Arcebispado da Bahia que recusam o candidato: “2. Se [o ordenando] é, ou foi herege apóstata de nossa Santa Fé, ou filho ou neto de Infiéis, Hereges, Judeus ou Mouros [...] 4. Se tem parte da nação Hebréia, ou de outra qualquer raça infecta: ou de Negro ou de Mulato” (VIDE, 1853, p.224, apud CASIMIRO, 2006, p.4).

No início do século XVI, a fundação da Companhia de Jesus, em 1540, e as disposições do Concílio de Trento (1545-1563) constituíram-se adaptadas ao enfrentamento dos novos desafios da modernidade e voltadas para responder aos problemas advindos da colonização moderna e da evangelização de novos povos. Em pouco tempo, a Companhia de Jesus já espalhara sua influência teológico-pedagógica nos principais pontos da Europa e do mundo colonial, tendo como premissa básica uma 'pedagogia' que doutrinava, justificava a doutrina, fiscalizava e punia. Isso aconteceu por intermédio das diversas ordens religiosas aqui instaladas, mas, prioritariamente, dos jesuítas, principais propagadores da fé e da Igreja Católica em todo o Reino Português. Estes últimos, com uma organização escolar mais ampla e 'eficiente', tiveram colégios espalhados por todo o Brasil e atuaram, não só na educação, mas, em todas as instâncias da vida colonial até o advento da política pombalina, quando foram expulsos, em 1759 (LEITE, 1938-1950, apud CASIMIRO, 2006).

A verdade é que, de acordo com Saviani (2007), diversas ordens religiosas se fizeram presentes no processo de colonização do Brasil, como os franciscanos, beneditinos, carmelitas, mercedários, oratorianos e capuchinhos, tendo sempre desenvolvido atividades educativas. 
Contudo, essas congregações religiosas operaram de forma dispersa e intermitente, sem apoio oficial. Os jesuítas, ao contrário, vieram por determinação do rei de Portugal, sendo apoiados não só pela coroa portuguesa, como também pelas autoridades da Colônia, e por isto puderam exercer o monopólio da educação nos dois primeiros séculos de colonização. E, de acordo com a "pedagogia e ética missionária” jesuítica, a sujeição do índio precedia a sua conversão (SAVIANI, 2007).

Coincidindo com essa fase de prosperidade da missão jesuítica no Brasil, a Companhia de Jesus elaborou um plano geral de estudos, implantado em todos os colégios da Ordem em todo o mundo, o qual ficou conhecido pelo nome de Ratio Studiorum. O plano contido no Ratio era de caráter duplo, sendo ao mesmo tempo universalista e elitista. Universalista porque se tratava de um plano adotado de forma indistinta por todos os jesuítas, em qualquer lugar do mundo onde estivessem. Elitista, porque destinava-se aos filhos dos colonos muito mais do que a outros, excluindo os indígenas, com o que os colégios jesuítas se converteram no instrumento de formação da elite colonial (SAVIANI, 2007).

$\mathrm{Na}$ atualidade, apesar de contar com uma legislação consoante com as tendências mais modernas dos países desenvolvidos, quais sejam as de uma escola pública única, gratuita e democrática, acessível a todos; e de que, das gerações que têm passado pela escola, muitos indivíduos aí iniciaram ou reconstituíram percursos de mobilidade social ascendente, não se pode desconsiderar o fato de que milhares de outros ficaram pelo caminho. Portanto, a atuação dos poderes públicos em relação à educação escolar no Brasil, na prática, mostrou-se bem diferente de sua pressuposta modernidade, uma vez que continuamos a ter dois tipos de escola: um para as classes dominantes, que conduz à Universidade, outro para os pobres que, em geral, limita-se ao ensino fundamental (PILETTI, 1991).

Ou seja: o ensino formal desenvolvido na escola está imbuído de novas e modernas funções, mas continua desempenhando com extrema eficiência uma função antiga: a de excluir.

Torna-se evidente, então, que ao se abordar a questão das políticas públicas em educação, e no caso que mais nos interessa aqui, em educação para a saúde, tem-se que considerar o quadro de exclusão que caracteriza o ensino público no Brasil.

Quanto à saúde pública, deve-se admitir que, no Brasil, ainda são incipientes as políticas voltadas à promoção da saúde e à prevenção das doenças, pois uma parcela significativa dos recursos públicos vai para a assistência - compra de medicamentos, internações, ações ambulatoriais e consultas médicas - ainda que ela esteja longe do ideal.

Conforme Vasconcelos (2001), até a década de setenta, a educação em saúde foi basicamente uma iniciativa das elites políticas e econômicas, e subordinadas aos seus interesses. 
Voltava-se, portanto, para a imposição de normas e comportamentos por elas considerados adequados, numa espécie de “estratégia pedagógica” que poderia ser denominada “toca boiada”, em que os técnicos e a elite conduziam a população para os caminhos que consideravam corretos, usando, para isto, tanto o berrante - a palavra -, como o ferrão - o medo e a ameaça.

Mas a partir da década de setenta, ainda de acordo com o mesmo autor, experiências alternativas estruturaram-se em bairros periféricos, pequenas cidades do interior e povoados rurais, integradas a projetos mais amplos nos quais a metodologia da Educação Popular (educação não-formal) era hegemônica. Estas experiências surgiram no mesmo ambiente sócio-econômico em que a Educação Popular se firmava como corpo teórico: as ações das comunidades eclesiais de base, o ressurgimento dos movimentos sociais em luta contra a ditadura militar e suas políticas econômicas e sociais.

A Educação Popular em Saúde tem sua origem, portanto, no início da década de 70, com as experiências de profissionais de saúde que atuavam no meio popular, no espaço aberto pelas Comunidades Eclesiais de Base, com o ressurgimento dos movimentos sociais de luta contra a ditadura. Vasconcelos (2001) relata que a participação de profissionais de saúde nas experiências de Educação Popular, a partir dos anos 70, trouxe para o setor saúde uma cultura de relação com as classes populares que representou uma ruptura com a tradição autoritária e normatizadora da educação em saúde.

Contudo, o referido autor afirma que, passados quarenta anos do início deste movimento no Brasil, muita coisa mudou. Com o processo de democratização da sociedade brasileira, abriuse espaço para que a participação popular também pudesse ocorrer dentro das instituições. Muitos técnicos saídos diretamente dos espaços informais dos movimentos sociais passaram a ocupar cargos estratégicos nós órgãos implementadores das políticas das políticas de saúde, procurando aplicar, neste novo espaço institucional, a metodologia da Educação Popular. Apesar de certa crise inicial, compreensível pela dificuldade de transposição de uma metodologia desenvolvida nos espaços populares para o espaço institucional, novas experiências floresceram. Um exemplo é a Rede de Educação Popular e Saúde que, desde 1991, vem articulando profissionais de saúde e lideranças populares envolvidas nestas experiências, e ao se expandir consolida a trajetória de atuação dos novos serviços de saúde a partir do instrumental da Educação Popular.

Nos serviços de saúde, por outro lado, trabalhava-se com a Educação para a saúde, concepção hegemônica do modelo tradicional de assistência à saúde, onde a educação é tida como um bem que tem de ser repassado ao e absorvido pelo paciente, uma ação prestada, um instrumento para viabilizar a saúde das pessoas, para que todos tenham saúde.(ALBUQUERQUE, 2003). 
No que concerne ao papel desta experiência sobre a saúde pública, Valla (1999) aborda a importância do apoio social como fator positivo na melhoria da saúde da população. Segundo o autor, apoio social se define como sendo qualquer informação, falada ou não, e/ou auxílio material oferecidos por grupos e/ou pessoas que se conhecem e que resultam em efeitos emocionais e/ ou comportamentos positivos. Investigações apontam para o papel do apoio social na manutenção da saúde, na prevenção contra a doença e como forma de facilitar a convalescença. Uma das premissas fundamentais destas teorias é a de que o apoio social exerce efeitos diretos sobre o sistema de imunidade do corpo, no sentido de aumentar a capacidade de as pessoas lidarem com o stress. Outro possível resultado seria a contribuição do apoio social para a sensação de coerência de vida e controle sobre a mesma, que afeta beneficamente seu estado de saúde. Inversamente, pode-se inferir que a ausência de apoio social diminui a resistência, tornando o indivíduo mais suscetível à doença. Contando com o apoio social, as pessoas reagem melhor a acontecimentos desestabilizadores, como a morte de alguém da família, a perda da capacidade de trabalhar, ou o despejo da casa onde reside.

Estes estudos têm demonstrado que os apoios disponíveis podem influir, beneficamente, no sentido de proporcionar fatores de proteção contra o aparecimento de doenças, oferecendo melhorias de saúde física, mental e emocional (CASSEL, 1974, apud VALLA, 1999). Conclui-se que um envolvimento em atividade comunitária, por exemplo, pode constituir um fator psicossocial significante na melhoria da confiança pessoal, da satisfação com a vida e da capacidade de enfrentar problemas, pois a participação social pode reforçar o sistema de defesa do corpo e diminuir a suscetibilidade à doença.

A valorização da promoção da saúde, tanto em iniciativas de ordem popular quanto as iniciativas institucionalizadas, passa, portanto, pela questão do apoio social e das oportunidades que ele oferece: realizar a prevenção através da solidariedade e do apoio mútuo, assumindo o controle do próprio destino e desenvolvendo a autonomia. Mas a educação em saúde não é uma tarefa fácil, principalmente no que concerne àquela parcela da população completamente imersa em situação de exclusão social: os mendigos, os desempregados, os moradores de rua, os menores abandonados, etc.

Como realizar educação alimentar para crianças que estão fora da escola? Como acompanhar pacientes sem domicílio fixo? Como recomendar a ingestão de medicamentos antes das refeições (fornecidos pelo SUS) a pacientes que não sabem quando, e nem se irão comer? Finalmente, como tratar doenças reconhecidamente de determinação social com procedimentos de enfoque bacteriológico (que leva em consideração o tratamento sob condições e padrões ideais de 
vida), fundamentos nos quais se baseia a atual hegemonia médica? Estas questões se aprofundam em nossos dias, quando as desigualdades e a exclusão social crescem em proporções assustadoras.

Evidentemente, a principal proposta de solução para os problemas de saúde determinados socialmente reside na prevenção. E falar em prevenção significa falar também em educação.

\subsection{A EDUCAÇÃo NÃO-FORMAL, A CIÊNCIA GEOGRÁfICA E A PESQUISA QUALITATIVA EM SAÚDE.}

A educação não formal corresponde a todas as ações educativas realizadas fora do sistema escolar, todas as formas não institucionalizadas, sem uma hierarquia estruturada e que não precise necessariamente de uma cronologia gradual na aprendizagem. (SIMSON, PARK e FERNANDES, 2001). A modalidade não-escolar (ações não-formais) ocorre em espaços diversos, como nas associações de bairro, nos movimentos sociais, igrejas, sindicatos, ONGs, espaços culturais e até mesmo nas escolas formais.

Utilizando-se de metodologias lúdicas, seqüências cronológicas diferenciadas, conteúdos flexíveis e aproximação da realidade dos sujeitos cuja demanda se pretende atender; procurando suscitar nestes mesmos sujeitos sua consciência de localização, identidade e pertencimento, a fim de que possam situar-se no mundo, a educação não-formal é muito próxima da metodologia da pesquisa-ação e também da educação geográfica ${ }^{5}$.

Gohn (1999) afirma que o principal objetivo da educação não-formal é a formação de cidadãos aptos a solucionar problemas do seu cotidiano, desenvolver habilidades diversas, capacitar para o trabalho, organizar-se coletivamente, apurar a compreensão do mundo à sua volta e ler criticamente a informação que recebem. Com base nesta afirmação, podemos estabelecer um paralelo com a Geografia, principalmente por abordar, entre seus conceitos, a importância do conhecimento do lugar e da sua realidade concreta como base para a construção da identidade e do sentido de pertencimento.

Fundamental para o êxito das ações educativas não-formais é conhecer e respeitar a cultura local, a cultura do outro, as características exclusivas do grupo em que vive em um determinado espaço, de modo a auxiliar no conhecimento do mundo, na construção da identidade e da cidadania.

A Geografia, na sua trajetória escolar, sempre cumpriu um papel importante na formação das pessoas. Contudo, com as propostas atuais, produtos de inúmeras pesquisas no

\footnotetext{
${ }^{5}$ Evidentemente, consideramos fundamental a importância da Geografia no âmbito, também, da educação formal. Contudo, a análise do papel desempenhado pela Geografia no ensino formal não foi objeto deste estudo.
} 
campo do ensino nos últimos anos e com a evolução da ciência geográfica, no que concerne aos seus principais conceitos e metodologias, os conhecimentos relacionados à educação geográfica podem e devem contribuir para outras modalidades de aprendizagem para além dos espaços escolares.

Torna-se necessário destacar, porém, e de acordo com Afonso (2001), que a valorização do campo da educação não-formal não pode implicar na desvalorização da educação escolar, sob o risco de incorrer em um discurso contra a escola, e por isso mesmo servir a quaisquer estratégias neo-liberais de desmonte dos sistemas públicos de ensino. Em alguns países assiste-se a um crescente sentimento anti-escola, quer pela subordinação dessa instituição aos poderes hegemônicos, quer por seu fracasso diante dos desafios do mundo moderno, e que se expressa por um movimento que preconiza a realização do ensino em casa (home schooling), o qual, somente e nos Estados Unidos, já conta com mais de um milhão e meio de crianças instruídas deste modo.

O referido autor salienta ainda que o campo da educação não-escolar (informal e nãoformal) sempre coexistiu com o campo da educação escolar, sendo mesmo possível constatar sinergias pedagógicas muito produtivas entre eles. Um exemplo refere-se à educação familiar, que inscreve-se dentro do campo da educação informal, e que, não obstante, continua a ser pensada como educação decisiva para o sucesso nos percursos de escolarização.

Neste sentido, a ciência geográfica tem muito a oferecer ao campo da educação nãoformal, pois preconiza o conhecimento profundo da realidade, para além das aparências, buscando a essência das expressões socioespaciais observadas e procurando, com isto, aproximar-se dos indivíduos (os sujeitos) e melhor compreendê-los, pois eles são os principais elementos forjadores deste espaço, e possuem com ele relação intrínseca. Assim, a ação educativa não-formal pode ser eminentemente relacionada à ação educativa geográfica, e à ciência geográfica, pois ambas buscam a compreensão do real, em suas dimensões espaciais, sociais, objetivas, subjetivas materiais e imateriais.

Se na educação escolar temos conteúdos geográficos distantes da realidade dos alunos e um conhecimento compartimentado pela normatização que caracteriza esta forma de educação, a hierarquia presente nas relações profissionais dentro deste ambiente acaba por cercear as ações educativas, enquadrando-as em determinados padrões que dificultam o alcance dos objetivos de emancipação esperados. Estes entraves não existem na educação não-formal, pois ela ocorre na forma de gestão, de “construir junto” sem a pressão (ou supressão) que tantas vezes ocorrem no ambiente escolar.

Na sociedade capitalista em que vivemos, estratificada econômica e socialmente, tornase difícil conceber que uma educação padronizada, cujos princípios básicos ignoram 
completamente esta estratificação (dando origem à tão debatida “crise na educação”), possa dar conta dos anseios e necessidades das comunidades carentes relativos à sua saúde.

Sabemos que a universalização do ensino a partir da década de 70 trouxe para o universo escolar formal as crianças e os adolescentes pertencentes às camadas populares que, anteriormente, e de forma muito cômoda para as classes dominantes, ficavam longe dos bancos escolares, ou deles em pouco tempo desistiam. Esta situação tem modificado a realidade.

Moreira e Candau (2003) destacam as indagações relativas ao(à) aluno(a) concreto(a) que agora encontram-se presentes na sala de aula: como lidar com essa criança tão "estranha”, que apresenta tantos problemas (de difícil solução), que tem hábitos e costumes tão "diferentes” dos da criança “bem educada”? Como “adaptá-la” às normas, condutas e valores vigentes? Como ensinar-lhe os conteúdos que se encontram nos livros didáticos? Como prepará-la para os estudos posteriores? Como integrar a sua experiência de vida de modo coerente com a função específica da escola?

Todavia, a despeito das conquistas e das contribuições de diversas experiências nas escolas e em espaços de educação não-formal, capazes de dar voz às minorias étnicas e raciais marginalizadas e às camadas populares, ainda não podemos considerar que uma orientação multicultural numa perspectiva emancipatória (SOUSA SANTOS, 2003, apud MOREIRA e CANDAU, 2003) costume nortear as práticas curriculares das escolas e esteja presente, de modo significativo, nos cursos que formam os docentes que nelas ensinam.

Os “outros”, os “diferentes” - os de origem popular, os afrodescendentes, os pertencentes aos povos originários, os rappers, os funkeiros etc. -, mesmo quando fracassam e são excluídos, ao penetrarem no universo escolar desestabilizam sua lógica e instalam outra realidade sociocultural. Essa nova configuração das escolas se expressa em diferentes manifestações de mal-estar, em tensões e conflitos denunciados tanto por educadores como por estudantes. É o próprio horizonte utópico da escola que entra em questão: a escola, nesse contexto, mais que a transmissora da cultura, da "verdadeira cultura”, passa a ser concebida como um espaço de cruzamento, conflitos e diálogo entre diferentes culturas ${ }^{6}$. Em vez de preservar uma tradição monocultural, a escola está sendo chamada a lidar com a pluralidade de culturas, reconhecer os diferentes sujeitos socioculturais presentes em seu contexto, abrir espaços para a manifestação e valorização das diferenças. A reflexão sobre esta temática é co-extensiva ao próprio desenvolvimento do pensamento pedagógico: não se pode conceber uma experiência

\footnotetext{
${ }^{6}$ Cultura entendida aqui como o sistema de representações que dá sentido, coerência e significado à vida coletiva. As culturas não diferem tanto pelos seus conteúdos, mas sobretudo pela maneira de organizar estes conteúdos, associá-los. Ela é composta de artefatos, valores, saberes ancestrais, costumes, e tem sempre uma perspectiva coletiva.
} 
pedagógica “desculturizada”, em que a referência cultural não esteja presente (MOREIRA e CANDAU, 2003).

Por isto, seria ideal a implementação de políticas públicas que se traduzissem em ações de vinculação da escola com sua comunidade local, com os problemas que a afetam, suas condições de vida, anseios e necessidades, invertendo-se os parâmetros históricos da conexão do ensino formal aos interesses dos poderes dominantes da sociedade. E com isto buscar, de acordo com Freire (2003), o desenvolvimento de uma educação que promova a participação, a atuação no sentido de resolver problemas e sugerir medidas, além de sentir-se responsável.

Nem toda educação não-formal, contudo, guarda os princípios básicos para que atinja seu êxito de forma ideal, sendo conduzidas de maneira "formalizada" ou "formalizante", por sua caracterização metodológica muito mais próxima à educação formal desenvolvida dentro do ambiente escolar institucionalizado, do que aos preceitos da educação não-formal. Há muitas propostas de educação que se dão fora da escola, mas que se utilizam de métodos hierarquizados na relação educador-educando.

Sendo assim, e buscando não cair na armadilha de uma educação não-formal hierarquizada, formal e formalizante, a educação para a saúde aproximou-se da Educação Popular em saúde, pois segundo Brandão (1982, apud VASCONCELOS, 2001), a Educação Popular em saúde não visa criar sujeitos subalternos educados: sujeitos limpos, polidos, alfabetizados, bebendo água fervida, comendo farinha de soja e utilizando fossas sépticas. Visa participar do esforço que já fazem hoje estes sujeitos subalternos para a organização do trabalho político que abra caminho para a conquista de sua liberdade e de seus direitos. Ainda segundo o mesmo autor:

Ela busca trabalhar pedagogicamente o homem e os grupos envolvidos no processo de participação popular, fomentando formas coletivas de aprendizado e investigação de modo a promover o crescimento da capacidade de análise crítica sobre a realidade e o aperfeiçoamento das estratégias de luta e enfrentamento. (p. 124).

Um elemento fundamental do método da Educação Popular é a consideração do saber anterior das classes populares, como ponto de partida do processo pedagógico. Ao valorizar o saber anterior do educando, é possível fazer com que ele se sinta mais à vontade, mantendo seu interesse e sua iniciativa. Deste modo, não se tem a passividade dos métodos pedagógicos tradicionais, pois não basta que o conteúdo discutido seja revolucionário, se o processo de discussão é antiquado e se mantém de forma vertical (VASCONCELOS, 2001). E através desta metodologia, desenvolver com a comunidade uma espécie de estratégia educativa onde, de 
acordo com Paulo Freire (1992), quem sabe possa ensinar a quem não sabe, sabendo no entanto que não sabe tudo; e quem não sabe, aprenda, mas sabendo sempre que não ignora tudo. Por Educação Popular entendemos, juntamente com Stotz (2005):

(...) como educação realizada nos movimentos populares, por meio da participação nas lutas nos mais variados espaços e na dinâmica interna das organizações populares. Trata-se de uma educação política que não se dissocia da vida cotidiana, a qual é base para a compreensão dos problemas no bairro e ponto de partida da reflexão sobre as estratificações sociais e de poder que refletem, no nível local, a estrutura social e política mais ampla. As pessoas educam-se na ação desenvolvida, descobrem a solidariedade e a opressão e, pela organização, a esperança de transformar a situação encontrada. A vida cotidiana se amplia, adquirindo sentido político que dela não se dissocia. (p.25).

Com a Educação Popular, portanto, não é possível cair no engodo da educação "homogênea” e "homogeneizante”, uma vez que, de acordo com Vasconcelos (2005), seu princípio básico reside no reconhecimento da sociedade dividida em classes sociais, da existência da dominação e da exploração, e na opção pela perspectiva das classes exploradas e dos grupos oprimidos. Nesse mesmo sentido, é por isso que a Educação Popular não é uma educação "para” o povo, com objetivos pré-definidos e conteúdos pré-estabelecidos. Ela se faz “com” o povo, tomando como ponto de partida do processo pedagógico o saber desenvolvido no mundo do trabalho, do convívio cotidiano, na luta pela sobrevivência, e procura incorporar os modos de sentir, de pensar e agir dos grupos explorados para ajudá-los em sua luta contra a opressão. Decorre dessas premissas que:

A Educação Popular e (em) Saúde não é um campo técnico-científico, mas um 'movimento social' singular, composto de pesquisadores, profissionais e técnicos do chamado setor saúde, e de ativistas, técnicos e lideranças dos movimentos e organizações sociais comprometidos em participar e ampliar os esforços de emancipação das camadas trabalhadoras do povo brasileiro. Trata-se de um movimento que, em sua heterogeneidade, participa de visões de mundo diferentes (cristianismo, humanismo e socialismo), mas compartilha a abordagem freiriana da educação (STOTZ, 2005, p.10).

Nisto a Educação Popular se aproxima metodologicamente da pesquisa-ação, ou pesquisa participante. Tanto é que, sobre sua evolução, Vasconcelos (2003, p. 195-196) observa:

A pesquisa em educação popular, a partir das influências fundantes de Paulo Freire, Marx e Malinowski e da Escola de Frankfurt, foi aos poucos se delineando como uma pesquisa qualitativa, com forte conotação da observação participante da antropologia, engajada na transformação política da sociedade na perspectiva dos interesses dos seus grupos sociais subalternos e onde os sujeitos investigados participam conscientemente do processo de produção do 
conhecimento. A esta metodologia de investigação se denominou, nos anos 80, pesquisa participante. Quando faz parte de seus objetivos refletir sobre uma determinada ação problemática realizada por pessoas ou grupos implicados na investigação, passa a se denominar pesquisa-ação.

Mas, segundo o autor, a pesquisa participante e a pesquisa-ação passaram a sofrer severas críticas a partir dos anos 90, quando o próprio movimento de educação popular começou a ser visto como algo ultrapassado. Vasconcelos (2003) relaciona as principais críticas à pesquisa-ação e à pesquisa participante:

a. A pouca consistência científica destas pesquisas, considerando que elas se aproximam da militância, e esta possui ações e consequências imediatas e diretas.

b. Por se dar sob a ideologia socialista dos anos 80, acabou por ser considerada homogeneizadora, pois apesar de partir dos saberes prévios do educando, tencionava desenvolver nele a consciência proletária, ou seja "partiria de diferentes para chegar a iguais”. Assim, estas pesquisas estariam marcadas pela geração de conhecimentos subordinados a um projeto utópico único, escamoteado sob a alegação de um projeto social racional e científico.

c. O movimento cultural pós-moderno esvaziou toda a legitimidade das análises teóricas globais, levou a uma descrença em qualquer idéia de progresso da humanidade e com isto atingiu em cheio as bases da educação popular (fortemente centrada no projeto socialista de superação das contradições capitalistas). Dentro desta postura, trabalhar em prol dos explorados é algo sem sentido, uma vez que não se acredita mais no progresso social. “Pra que tanta agitação a propósito de coisa nenhuma?” (BERMAN, 1986, p. 32; apud VASCONCELOS, 2003, P. 198).

d. A pesquisa e a prática em educação popular tiveram sua utilidade e eficácia durante o regime militar, quando atuavam junto a grupos marginais bem delimitados, acompanhados por um longo período. Hoje, com os órgão público, ONG’s e organizações populares que atuam junto a clientelas amplas, heterogêneas e complexas, sua metodologia não seria mais adequada, e valorizá-las seria saudosismo.

Para Brandão (1990), a pesquisa participante é uma modalidade de conhecimento coletivo do mundo e das condições de vida das pessoas, grupos e classes populares. A expressão aparentemente neutra que existe na idéia de "objeto de pesquisa”, muitas vezes subordina a idéia e a intenção de que aqueles cuja "vida” e "realidade” afinal se "conhece”, sejam reconhecidos para serem objetos também da História. Entretanto, ainda segundo o autor, surgem sinais de crítica, tanto entre pesquisadores quanto pesquisados. Pessoas reais, e não apenas categorias 
abstratas de “objetos” parecem descobrir com a sua própria prática que devem conquistar o poder de serem o sujeito, tanto do ato de conhecer de que tem sido objeto, quanto do trabalho de transformar o conhecimento e o mundo que os transforma em objetos.

Conhecer a sua própria realidade. Participar da produção deste conhecimento e tomar posse dele. Aprender a escrever a sua história de classe. Aprender a reescrever a História através da sua história. Ter no agente que pesquisa uma espécie de gente que serve. Uma gente aliada, armada dos conhecimentos científicos que foram sempre negados ao povo, àqueles para quem a pesquisa participante - onde afinal pesquisadores-e-pesquisados são sujeitos de um mesmo trabalho comum, ainda que com situações e tarefas diferentes - pretende ser um instrumento a mais na reconquista popular (BRANDÃO, 1990, p. 11).

Ao insistir para que os pesquisadores desistam de sua "arrogância erudita”, Brandão diz que o pesquisador deve aprender a ouvir discursos diferentes de seu círculo acadêmico, e tentar a aprender e descobrir com humildade. Preconiza as técnicas dialogais ou de participação como referências para todo esforço que procure estimular a ciência popular, ou para se aprender com a cultura e a sabedoria popular, ampliando este conhecimento até um nível mais geral.

Segundo o mesmo autor, é disto que trata a pesquisa participante: de uma participação que não envolve somente uma atitude do cientista para conhecer melhor a cultura que pesquisa como se faz na observação participante da antropóloga social. Ela determina, outrossim, um compromisso que subordina o próprio projeto científico de pesquisa ao projeto político dos grupos populares cuja situação de classe, cultura ou história se quer conhecer porque se quer agir.

Nisto reside a importância da pesquisa-ação, relevante até mesmo como instrumento de reorientação da prática médica. Trata-se de uma metodologia de produção de conhecimento sobre a interrelação entre os atores e saberes envolvidos em uma prática social, em que se priorizam os interesses e as falas dos atores subalternos. Pesquisas com esta orientação contribuem muito para direcionar o movimento de construção de uma medicina integral que movimentos sociais, profissionais de saúde e outras organizações da sociedade civil já vêm realizando em suas lutas e trabalho. "Como uma metodologia qualitativa, ela é muito adequada para entender a dinâmica desse processo de interrelação, participação e interdisciplinaridade. Nesse sentido pode ser importante na superação do caráter fragmentado da medicina, bem como da sua concentração nas dimensões estritamente biológicas das doenças” (VASCONCELOS, 2003, p. 201).

Com a pesquisa-ação, novas perspectivas são incorporadas ao conhecimento do que afeta a saúde de um grupo ou de uma comunidade. O espaço de diálogo aberto pela pesquisa leva 
à participação de outros atores e sujeitos que nunca são convidados a entrar em cena para participar: eles constituem os alvos das políticas públicas, mas jamais são chamados a opinar; são objetos de pesquisas médicas, mas não podem se pronunciar. Com a introdução desta modalidade de pesquisa na educação em saúde há um ganho inicial inegável: de alvo e objeto de pesquisa e políticas públicas, as pessoas retornam à sua condição inerente - a de seres humanos. E, posteriormente, os seres humanos envolvidos na pesquisa passam a dialogar e buscar em conjunto alternativas únicas, particulares, de enfrentamento não só dos problemas de saúde, mas dos problemas do bairro, das famílias, dos desempregados, dos que moram em condições precárias, e de todas as outras angústias e necessidades que constituem o seu dia-a-dia. Muitas vezes erra-se, ao invés de acertar. Mas estes acerto e erros constituem ricas construções coletivas, cujas práticas e conhecimentos gerados vêm imbuídos da incorporação da diversidade de idéias que acorrem à oportunidade de participação popular. Idéias que traduzem saberes outros, nunca antes requisitados ou considerados e que, unidos, podem trazer avanços e configurar em uma resposta, e em um “saber fazer” próprio e eficiente.

Vasconcelos (2003) afirma que a grande razão para se continuar a insistir em pesquisas voltadas para a temática da educação popular utilizando a metodologia da pesquisa-ação foi o nascimento, nos anos 90, de um movimento social denominado A Articulação Nacional de Educação Popular em Saúde. O movimento colocava em pauta questões referentes à temática, aos problemas e preocupações não de um grupo decadente e saudosista, mas que tencionava o redirecionamento do Sistema Único de Saúde - SUS, responsável pelo atendimento de saúde da maioria da população brasileira. “A aparência de racionalidade pura que envolvia os vários projetos sociais foi desmascarada. Sabe-se hoje que todos se assentam sobre subjetividades, utopias, religiões ou mitos” (VASCONCELOS, 2003, p. 197).

“A neutralidade frente ao mundo, frente ao histórico, frente aos valores, reflete apenas o medo que se tem de revelar o compromisso”. Paulo Freire, discutindo o compromisso dos profissionais com a sociedade, completa: os que se dizem neutros "estão comprometidos consigo mesmos, com seus interesses e com os interesses dos grupos aos quais pertencem. E como este não é um compromisso verdadeiro, assumem a neutralidade impossível’ (FREIRE, 2001,p.19). A educação popular, pensada por Freire, busca refletir, questionar, analisar os fatos sociais, para justamente transformá-los junto com aqueles sujeitos constituídos no processo, no envolvimento do trabalho. 
Capítulo 2. Diálogos sobre moscas domésticas: ponto de partida da problematização.

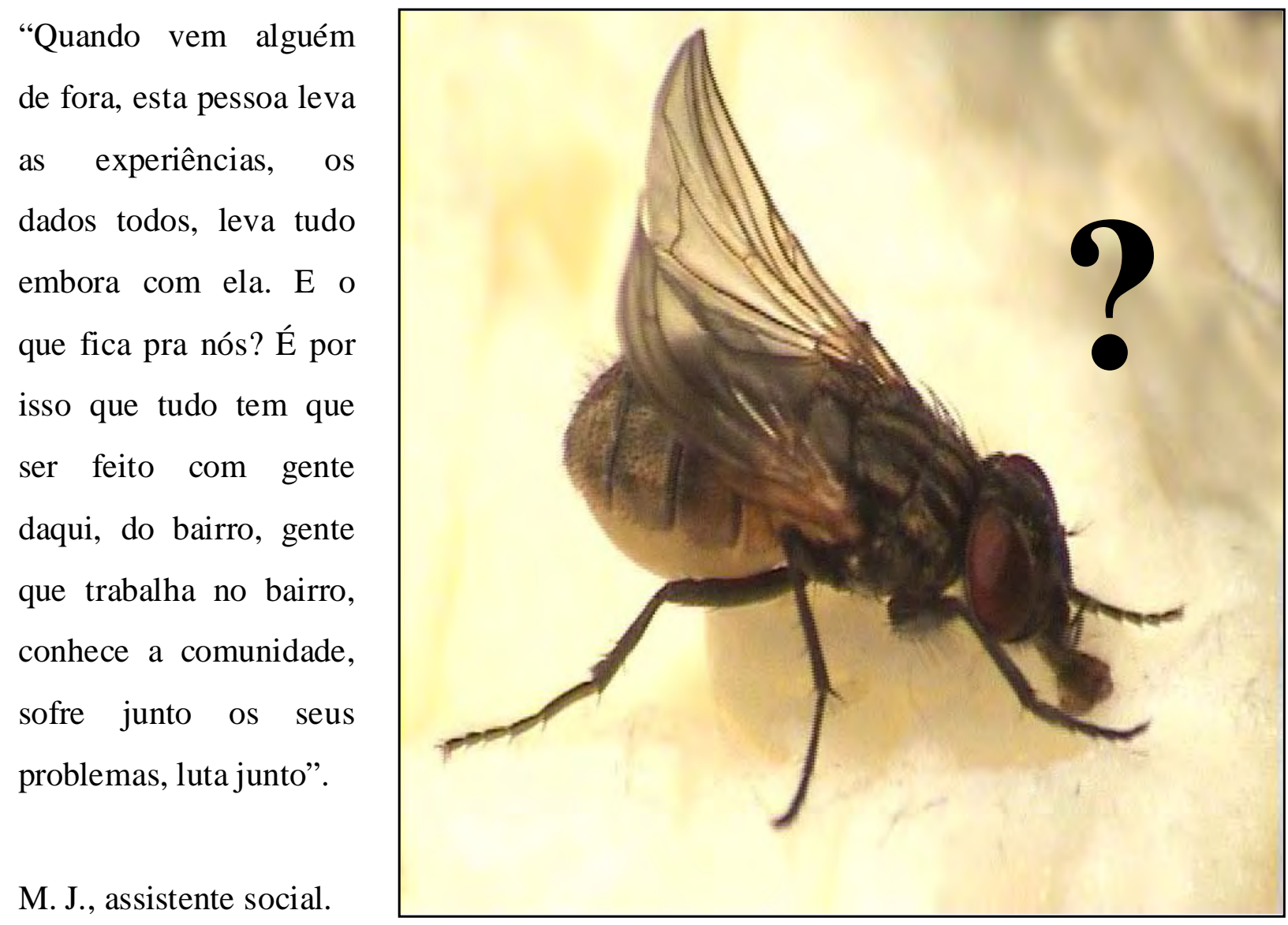


Esta pesquisa está inserida no âmbito do Laboratório de Geosaúde, cujos trabalhos encontram-se engajados em duas linhas de pesquisa: processo saúde/doença e políticas de saúde.

Com relação à observação participante, segundo Pereira, M. P. B. (2008), esta pode ser entendida como uma técnica utilizada para registrar fenômenos vivenciados entre o pesquisador e o pesquisado, durante o contato entre ambos (MINAYO, 1998, apud PEREIRA, 2008). Sua utilização ocorre quando há necessidade de registrar fenômenos que não podem ser apreendidos na fala ou escrita. Dentre esses elementos, podemos destacar: “o ambiente, os comportamentos individuais e grupais, a linguagem não-verbal, a seqüência e a temporalidade em que ocorrem os eventos” (VÍCTORA, KNAUTH, HASSEN, 2000, p.62, apud PEREIRA, 2008), os quais são fundamentais na interpretação e complementação de informações de outras técnicas utilizadas.

A observação participante é voltada para a descrição de uma problemática a partir do contato direto com o exercício das atividades. Por esta razão, devem ser definidos previamente os itens a serem observados. De acordo ainda com os mesmos autores, essa técnica está aberta ao conhecimento da realidade de acordo com os acontecimentos naturais a ela, porém "a definição do objeto, técnicas e análise dos dados estão centrados no pesquisador” (2000, p. 64).

Para a presente pesquisa utilizou-se a técnica da observação participante para o acompanhamento das coletas dos dípteros (incluindo a preparação correta das armadilhas), sua preparação e posterior classificação; além dos demais aspectos inerentes a este estudo de natureza interdisciplinar.

\section{QUADRO 1}

QUADRO 1
\begin{tabular}{|l|l|}
\hline \multicolumn{2}{|c|}{ ROTEIRO-BASE DOS ITENS DA OBSERVAÇÃO PARTICIPANTE } \\
\hline $\begin{array}{l}\text { I. Dados a serem observados na área de } \\
\text { trabalho: }\end{array}$ & $\begin{array}{l}\text { II. Dados a serem observados “fora” da área de } \\
\text { trabalho: }\end{array}$ \\
\hline $\begin{array}{l}\text { a) O Laboratório de Geografia da Saúde, a } \\
\text { disposição e organização dos instrumentos de } \\
\text { trabalho. }\end{array}$ & $\begin{array}{l}\text { a) A relação saúde e ambiente, considerando a forma } \\
\text { de propagação de vetores. }\end{array}$ \\
\hline b) Procedimentos de preparação das armadilhas. & $\begin{array}{l}\text { b) A etiologia da mosca doméstica e suas correlações } \\
\text { com agentes patogênicos. }\end{array}$ \\
\hline $\begin{array}{l}\text { c) A colocação das armadilhas; técnicas e cuidados } \\
\text { necessários ao seu bom aproveitamento. }\end{array}$ & $\begin{array}{l}\text { c) O processo de aprendizagem que o estudo desse } \\
\text { objeto exige para estudantes de graduação em geografia. }\end{array}$ \\
\hline $\begin{array}{l}\text { d) A coleta dos dípteros, procedimentos de } \\
\text { captura. }\end{array}$ & $\begin{array}{l}\text { d) O vínculo da universidade com a comunidade e os } \\
\text { serviços de saúde e educação das áreas de estudo. }\end{array}$ \\
\hline $\begin{array}{l}\text { e) Conservação dos dípteros para posterior } \\
\text { classificação. }\end{array}$ & e) A reação da população local a respeito da pesquisa. \\
\hline f) Classificação. & $\begin{array}{l}\text { f) O grau de colaboração das pessoas em relação à } \\
\text { pesquisa. }\end{array}$ \\
\hline
\end{tabular}

Elaborado por TORREZAN, R. M. (2007) 
Para o acompanhamento de campo, portanto, foi elaborado um roteiro com dois temas básicos, o primeiro relacionado às informações a serem observadas na área de trabalho; e o segundo referente a informações a serem percebidas em ambientes "fora” da área imediata de trabalho (Quadro 1), estando, porém, intimamente a ela relacionado. Contudo, incluídos nesses dois temas estão também presentes a observação do comportamento das pessoas do grupo, as linguagens e os relacionamentos em que ocorrem os processos observados.

\subsection{PESQUISA COM MOSCAS DOMÉSTICAS, SAÚDE E AMBIENTE.}

As moscas e os mosquitos pertencem ao Filo Arthropoda, Classe Insecta, Ordem Diptera (MARICONI et al, 1999).

Esta Ordem apresenta metamorfose completa (ovo, larva, pupa e adulto) e abrange as moscas e os mosquitos. Os dípteros apresentam apenas um par de asas membranosas, daí advém o nome da Ordem: Diptera ( $\mathrm{di}=$ duas; ptera = asas), o que distingue esta Ordem das demais Ordens. O aparelho bucal, por sua vez, é adaptado para picar e sugar, ou apenas sugar (MARICONI et al, 1999).

Do ponto de vista médico, os dípteros são os insetos mais importantes da Classe. Alguns deles são hematófagos, como os pernilongos, borrachudos, mutucas, e outros que podem ser veículo de sérias doenças, tais como a febre amarela, a malária e a filariose. Entretanto, há espécies como a mosca doméstica e a varejeira que, embora não sejam hematófagas, são também importantes vetoras de doenças, como disenteria, febre tifóide, poliomelite etc. (MARICONI et al, 1999).

Entre as moscas de interesse médico-sanitário, destacam-se as famílias Muscidae e Calliphoridae. A ocorrência, distribuição e predominância destes dípteros são fatores de grande importância em saúde pública (MARICONI et al, 1999).

As capturas dos dípteros foram realizadas semanalmente nos bairros Jardim Morada do Sol e Residencial Francisco Belo Galindo, em Presidente Prudente, no período de junho de 2007 a julho de 2008.

Para a coleta foram alocadas seis armadilhas confeccionadas com garrafas tipo "pet” de dois litros (CUNHA; LOMÔNACO, 1996, apud SEOLIN DIAS, 2008) localizadas em seis pontos, dispostas a uma altura de 1,0 a $1,70 \mathrm{~m}$ do solo. 
A escolha do estudo das moscas domésticas pelo Laboratório de Geografia da Saúde teve por referência várias pesquisas sobre o tema. A pesquisa foi realizada em bairros centrais e periféricos da malha urbana, permitindo a realização de comparações entre eles.

A coleta das moscas contou com o apoio da população local, uma vez que era necessário manter as armadilhas em locais adequados, dentro do terreno dos domicílios. Durante o período de levantamento dos dados de campo, a comunidade do bairro começou a ficar mais atenta às moscas, criando uma expectativa do retorno que poderia resultar da pesquisa realizada. A partir daí delineou-se a presente pesquisa, em função da necessidade de trabalhar com a população as relações entre moscas domésticas e saúde ambiental, partindo do desejo de compreensão da própria população a respeito do tema.

Assim, nessa primeira fase foi possível identificar e problematizar, junto à comunidade local, questões pertinentes à educação em saúde, como por exemplo:

I. A relação saúde e ambiente, considerando a forma de propagação de vetores;

II. A etiologia da mosca doméstica e suas correlações com agentes patogênicos;

III. O processo de aprendizagem que o estudo desse objeto exige para estudantes de graduação em geografia;

IV. O vínculo da universidade com a comunidade e os serviços de saúde e educação das áreas de estudo.

As moscas têm sido consideradas importantes vetores mecânicos de doenças disseminadas no meio urbano, uma vez que são transmissoras de microorganismos patogênicos como vírus, bactérias, cisto de protozoários e ovos de helmintos no ambiente doméstico. Em função disto, é crescente o número de estudos a respeito do comportamento, formas de dispersão, distribuição e diversidade de espécies.

No trabalho de colocação das armadilhas e de coleta das amostras, iniciou-se espontaneamente um processo de sensibilização da população local a respeito da relação existente entre saúde e ambiente, algo sentido mas não refletido pelas pessoas em seu cotidiano. A simples observação desta pesquisa pela população (a colocação das armadilhas, as iscas que continham, a quantidade de moscas capturadas) proporcionou novo âmbito de indagações a respeito das doenças que poderiam ser causadas pelas moscas, como poderiam ser evitadas, e de que forma a proliferação destes insetos estaria ligada ao ambiente e suas características. E, ao final do período de coleta dos dípteros, surgiram cobranças a respeito da devolutiva esperada sob a forma de uma ação educativa. 
Entre as espécies de dípteros muscóideos sinantrópicos de maior interesse para a Saúde Pública associadas às atividades antrópicas estão aquelas que apresentam um comportamento especialmente sinantrópico (o ciclo de vida se desenvolve completamente no ambiente antrópico, sendo difícil sua sobrevivência em ecossistemas naturais). Certas espécies de moscas apresentam também um tipo de comportamento denominado comunicativo, pois se encontram comumente associadas aos resíduos orgânicos (fonte de alimento e/ou criadouro das moscas: lixo, esterco, carcaças etc.), os quais por conterem bioagentes patogênicos para o ser humano, se apresentam como importantes fontes de contaminação. Essas espécies de moscas, após o contato com tais resíduos são encontradas com maior freqüência no interior de residências (cozinhas, quartos e salas), escolas, hotéis, restaurantes e similares, sendo fortemente atraídas pelos alimentos e artigos manuseados pelo ser humano no seu domicílio. Disso resulta o seu papel como vetor mecânico na epidemiologia de algumas doenças transmissíveis, em particular de doenças diarréicas, o que se torna mais grave em áreas de população de baixa renda e com condições insuficientes de higiene pessoal e/ou ambiental, em assentamentos urbanos ou rurais (SANTOS, 2006).

O conceito de praga se aplica a algumas espécies de dípteros muscóideos que se dispersaram e expandiram suas áreas de ocorrência para regiões onde eram inexistentes, como o verificado, por exemplo, com Musca domestica L. (Muscidae), espécie cosmopolita, e as varejeiras do gênero Chrysomya spp (Calliphoridae), espécies, atualmente, quase cosmopolitas. Musca domestica está entre as espécies de dípteros muscóideos de importância sanitária que mais se beneficiam das falhas ou insuficiência no manejo dos resíduos orgânicos gerados e/ ou acumulados nas atividades antrópicas descritas. O mesmo se verifica para Chrysomya megacephala (Fabricius) (Calliphoridae), varejeira exótica introduzida no país na década de 1970. As duas espécies de moscas se destacam entre as espécies de dípteros muscóideos sinantrópicos freqüentes nos domicílios urbanos em várias regiões do mundo e que apresentam comportamento fortemente sinantrópico e domiciliado, esse último, ainda, não estabelecido nas populações de $C$. megacephala presentes nos municípios paulistas. Ambas as espécies de moscas desempenham importante papel como vetor mecânico na veiculação de bioagentes patogênicos (vírus, bactérias, protozoários e helmintos), principalmente, de doenças entéricas (SANTOS, 2006). 


\section{Família Muscidae (Espécie Musca domestica).}

Segundo Seolin Dias (2008), a espécie Musca domestica (Figuras 1 e 2), pertencente à família Muscidae, e popularmente conhecida como “mosca doméstica”, é uma mosca nãohematófaga, cosmopolita, de alto poder reprodutivo, que prolifera em vários tipos de substratos, tantos no meio urbano quanto no meio rural. Ela possui tamanho médio (6 a $8 \mathrm{~mm}$ ) e aparelho bucal não pungitivo (probóscida robusta, flexível, tipo lambedor); possui coloração acinzentada, com faixas claras e escuras intercaladas no tórax e abdômen amarelado; e suas larvas têm um aspecto vermiforme, de uma coloração esbranquiçado e muito móvel.

Na mosca doméstica, o aparelho bucal é constituído de uma probóscida, em cuja extremidade se localiza a labela, que é utilizada para sugar substâncias líquidas (Mariconi et al, 1999).

FIGURA 1. Mosca pertencente à Família Muscidade (mosca doméstica).

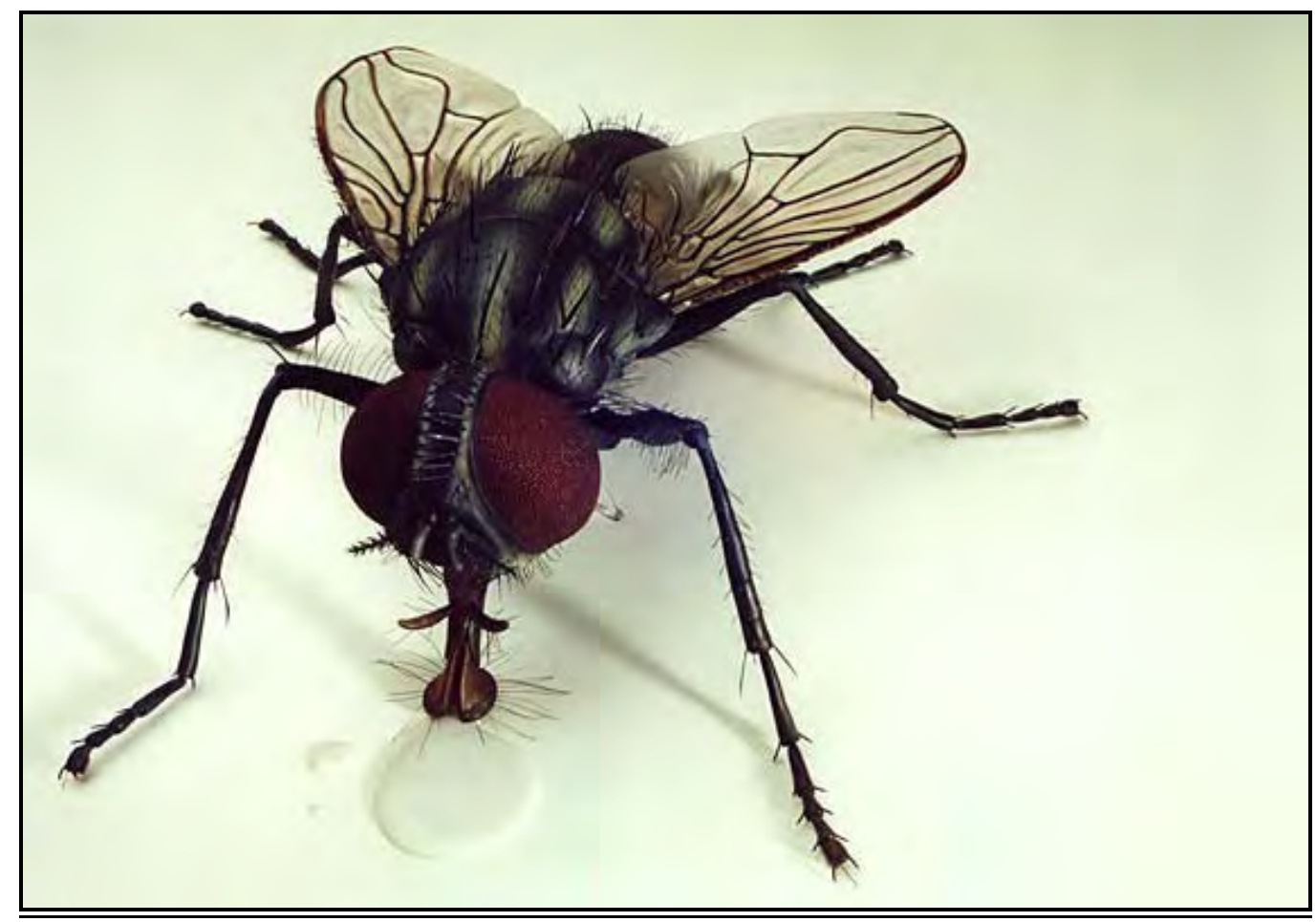

Fonte: Image source: http://www.bugbustersgsy.com/housefly.htm

Escala 1: 10 
FIGURA 2. Mosca pertencente à Família Muscidade (mosca doméstica).

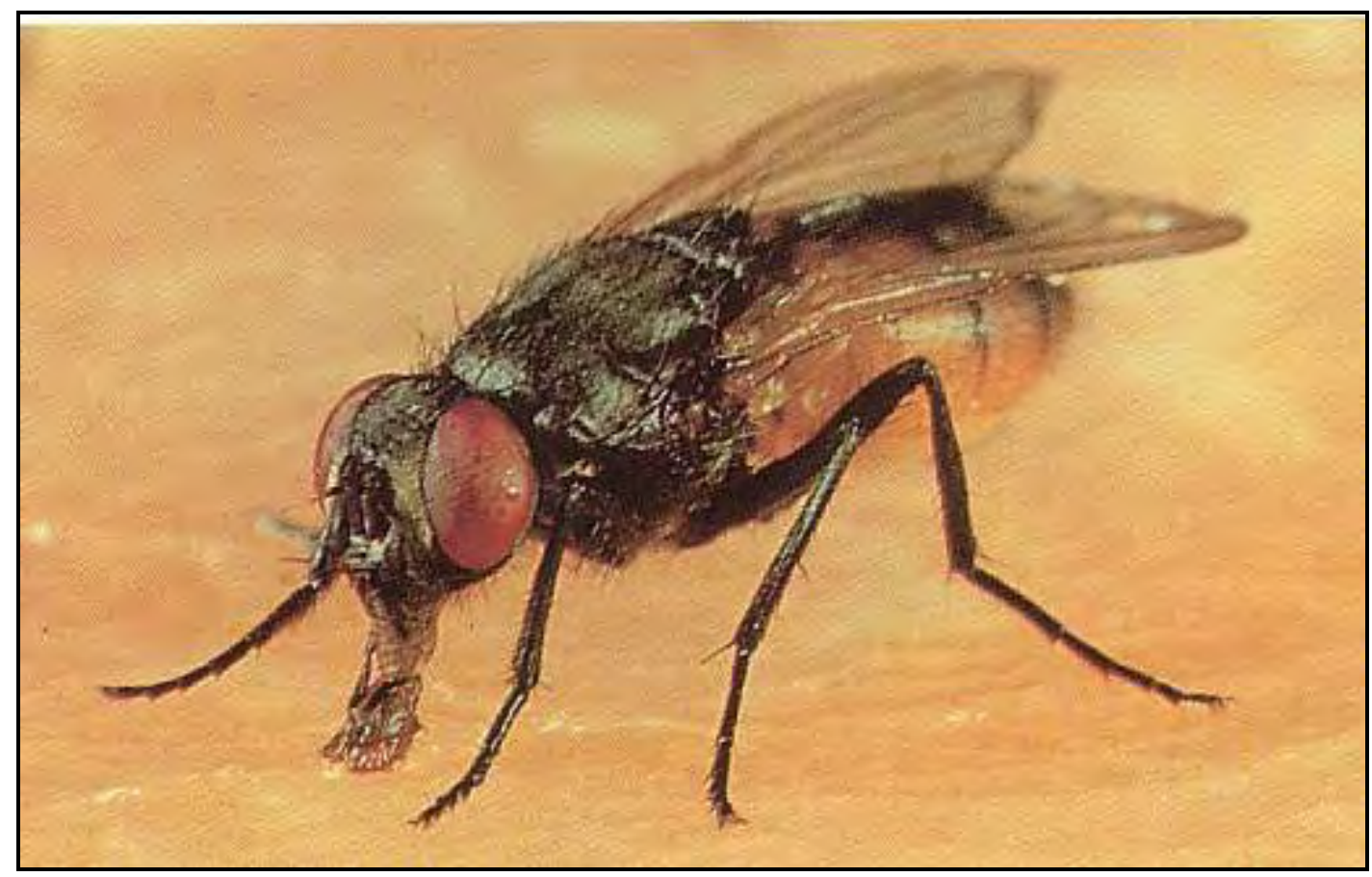

Fonte: image source: http://www.bugbustersgsy.com/housefly.htm)

Escala 1: 10

Esses insetos apresentam metamorfose completa e se desenvolvem através dos estádios: ovo, larva, pupa e adulto (Fig. 3).

FIGURA 3. Ciclo biológico da mosca doméstica.

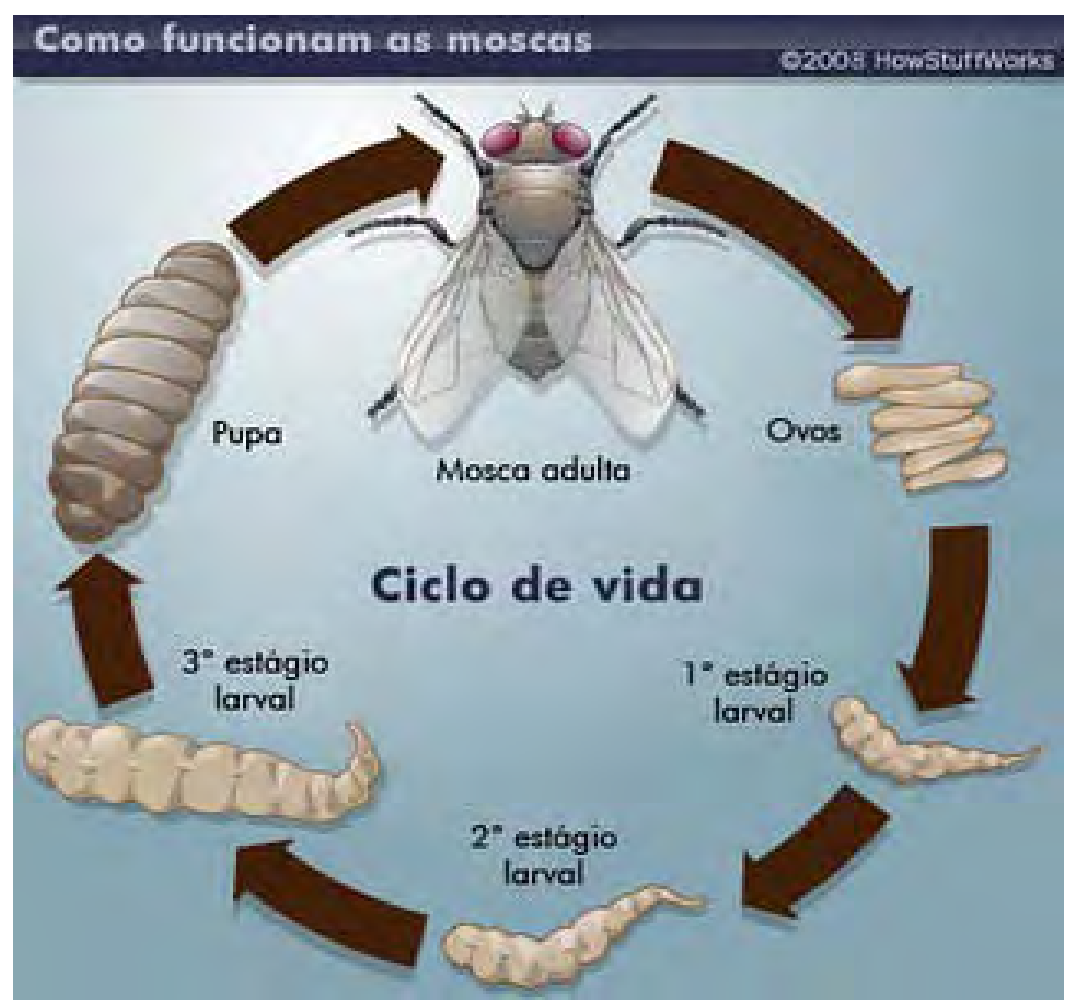

Fonte: http://2.bp.blogspot.com/housefly-life-cycle.jpg 
Após a metamorfose, os adultos emergem do pupário. Cada fêmea deposita ovos em grupos de 75 a 150 por postura e faz, geralmente, cinco a seis oviposturas em sua vida. Os ovos eclodem de oito a 24 horas, dependendo da temperatura ambiente, sendo que o ciclo completo ovo-ovo dura em média 8 a 20 dias. Normalmente, as fêmeas dessa espécie depositam seus ovos em matéria orgânica de origem vegetal e/ou animal em decomposição (fermentação ou putrefação), tais como fezes animais, carcaças de animais, lixo de origem doméstica, restaurantes, terrenos baldios e lixões a céu aberto, onde as larvas se desenvolvem (SEOLIN DIAS, 2008).

As moscas adultas alimentam-se de substâncias líquidas ou que se liqüefazem: fezes, escarro, pus, exsudato de feridas, produtos animais e vegetais em decomposição entre outros. As substâncias líquidas são diretamente ingeridas, ao passo que as sólidas são dissolvidas pela saliva e um líquido regurgitado do tubo digestivo. Essa regurgitação pode ser observada em toda a superfície em que a mosca toca a probóscida e é confundida com a defecação. Em vista disto, a Musca domestica é uma espécie de grande interesse sanitário, por ser apontada como veiculadora mecânica e/ou biológica de diversos agentes patogênicos ao homem e aos animais Esses agentes podem ser transportados no corpo, nas patas, nas fezes, nas peças bucais (tromba), e, principalmente, no vômito (SEOLIN DIAS, 2008).

A mosca doméstica, como se vê, raramente age como hospedeiro intermediário, porém quase sempre atua como transportador mecânico. Ela pode atuar sob três mecanismos distintos de transmissão: a) ingestão de agentes patogênicos e sua eliminação nas fezes; b) regurgitação de agentes patogênicos, após o armazenamento temporário e sua regurgitação em forma de vômito, enquanto se alimenta; c) dispersão dos germes no substrato alimentar, com auxílio das pernas e labela.

Atribui-se ainda à mosca doméstica, por seus hábitos de vida, a responsabilidade de transportar microorganismos causadores de febre tifóide, disenteria infantil, cólera, mastite bovina; de protozoários como Entamoeba sp, Giardia spp; de ovos de helmintos como Taenia ssp e Dipylidium eaninum (SEOLIN DIAS, 2008).

\section{Familia Calliphoridae (Espécies Chrysomya megacephala, C. albiceps e C. putoria).}

A família Calliphoridae (Figuras 4 a 6), conhecida popularmente como “mosca varejeira”, é caracterizada por apresentar indivíduos de tamanho médio a grande (4,0 a 16,0 mm), abdome arredondado ou oval, de coloração escura, em sua maioria, com reflexos metálicos 
azulados, violáceos, esverdeados ou cúpreos, principalmente no tórax e abdome. Suas larvas possuem o corpo afilado na parte anterior, com fortes ganchos bucais, e truncado na parte posterior, onde se abrem as placas respiratórias (SEOLIN DIAS, 2008).

Esse grupo de moscas possui as mesmas etapas de desenvolvimento que as da mosca doméstica, e o ciclo de vida de 10 a 20 dias, sendo que o seu aparelho bucal é do tipo lambedor como o da mosca domestica.

Os califorideos do gênero Chrysomya, com mais de 30 espécies descritas, são originarias do Velho Mundo e da África. Três espécies (Chrysomya megacephala, C. albiceps e C. putoria) foram introduzidas na América do Sul por meio de embarcações que transportavam refugiados do continente Africano. A primeira observação dessas moscas no Brasil ocorreu em 1975, no Paraná, e desde então, espalharam-se para todo o território nacional (IMBIRIBA et al., 1977; GUIMARÃES et al., 1979; MADEIRA, 2008, apud SEOLIN DIAS, 2008).

FIGURA 4. Mosca da Família Calliphoridae (Chrysomya albiceps)

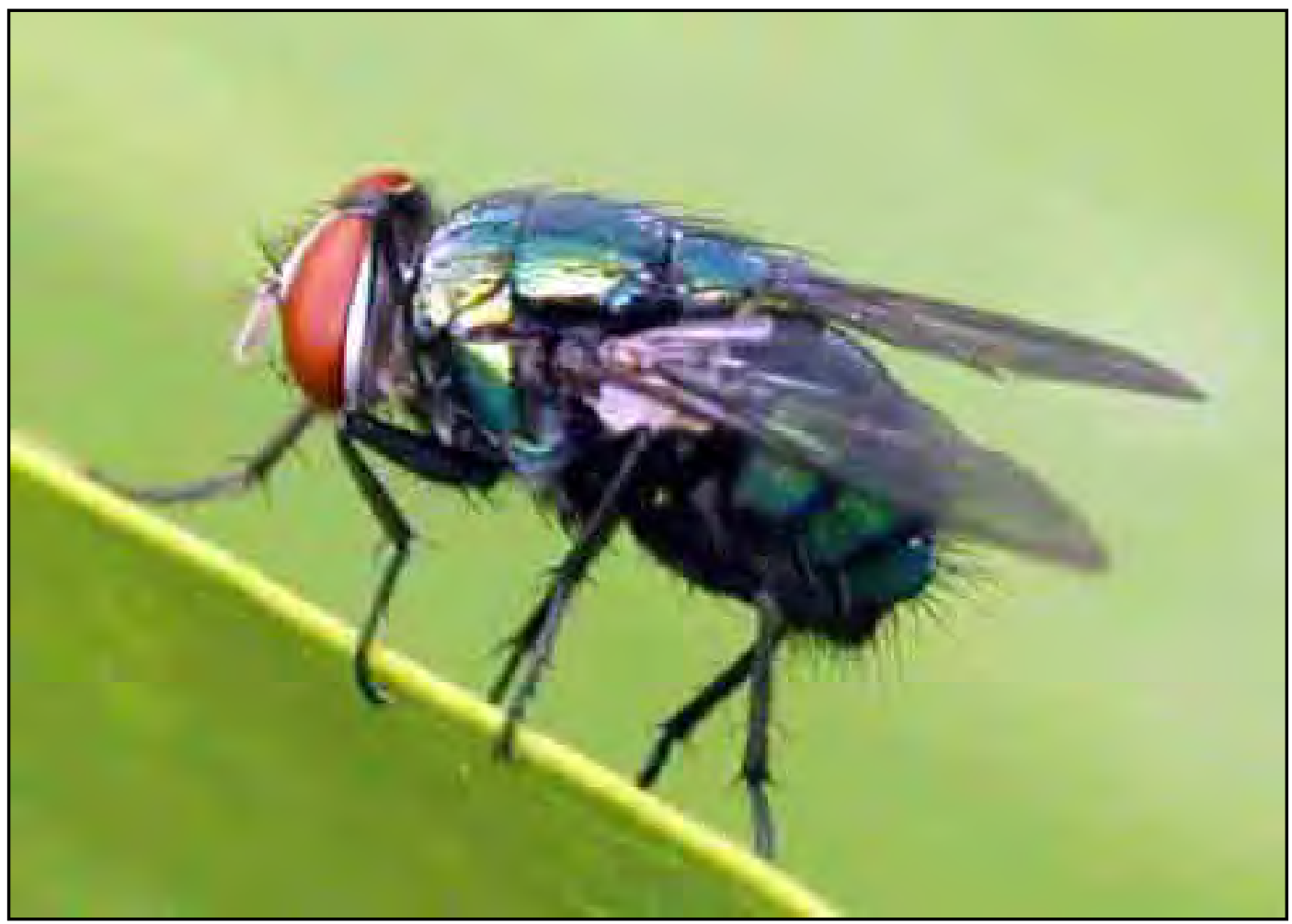

Fonte: http://photography-on-the.net/forum/showthread.php?t=166640

Escala 1: 10 
FIGURA 5. Mosca da Família Calliphoridae (Chrysomya megacephala).

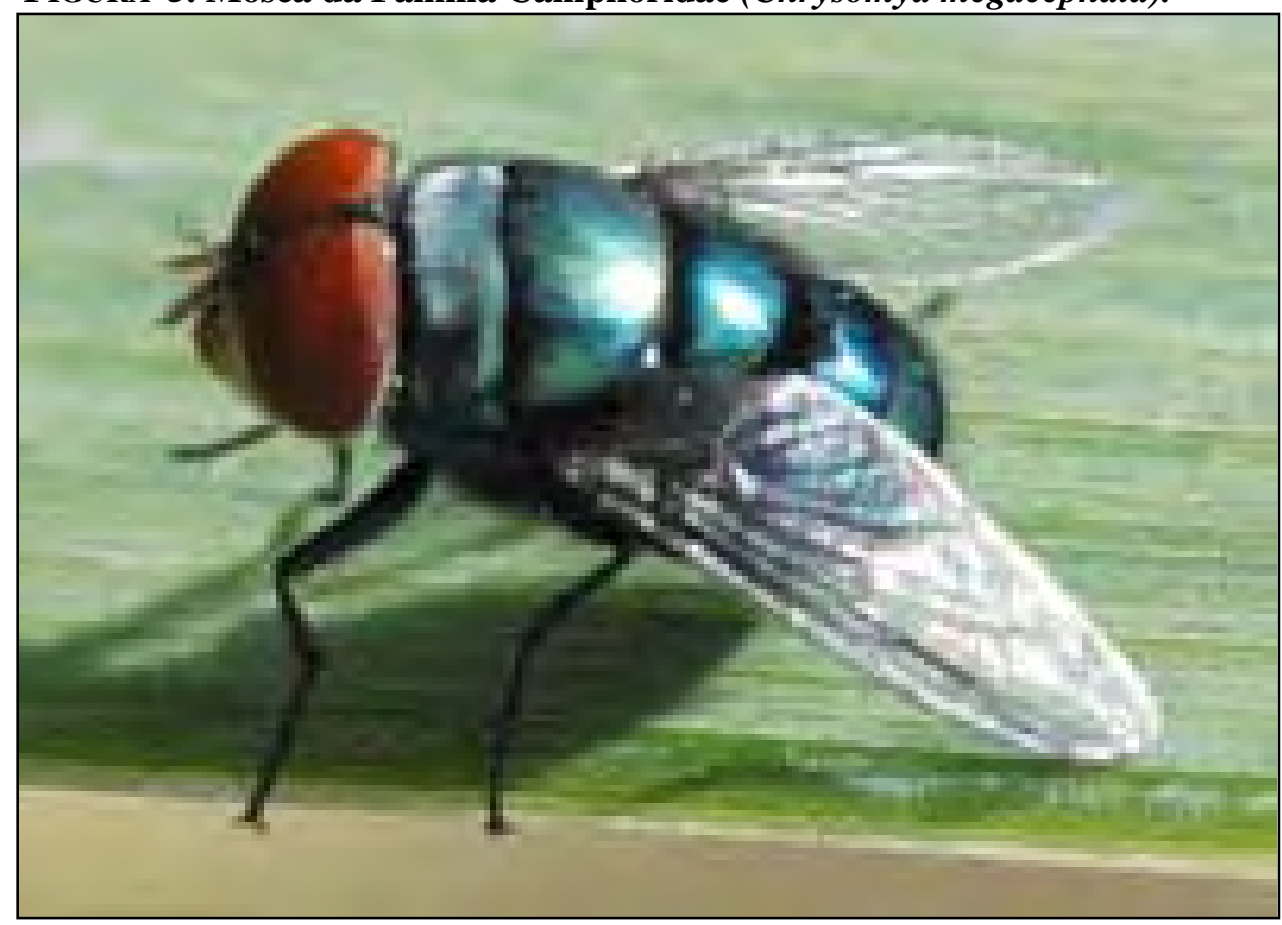

Fonte: nathistoc.bio.uci.edu/diptera/index.htm

Escala 1: 10

FIgURA 6. Mosca da Família Calliphoridae (Chrysomya putoria).

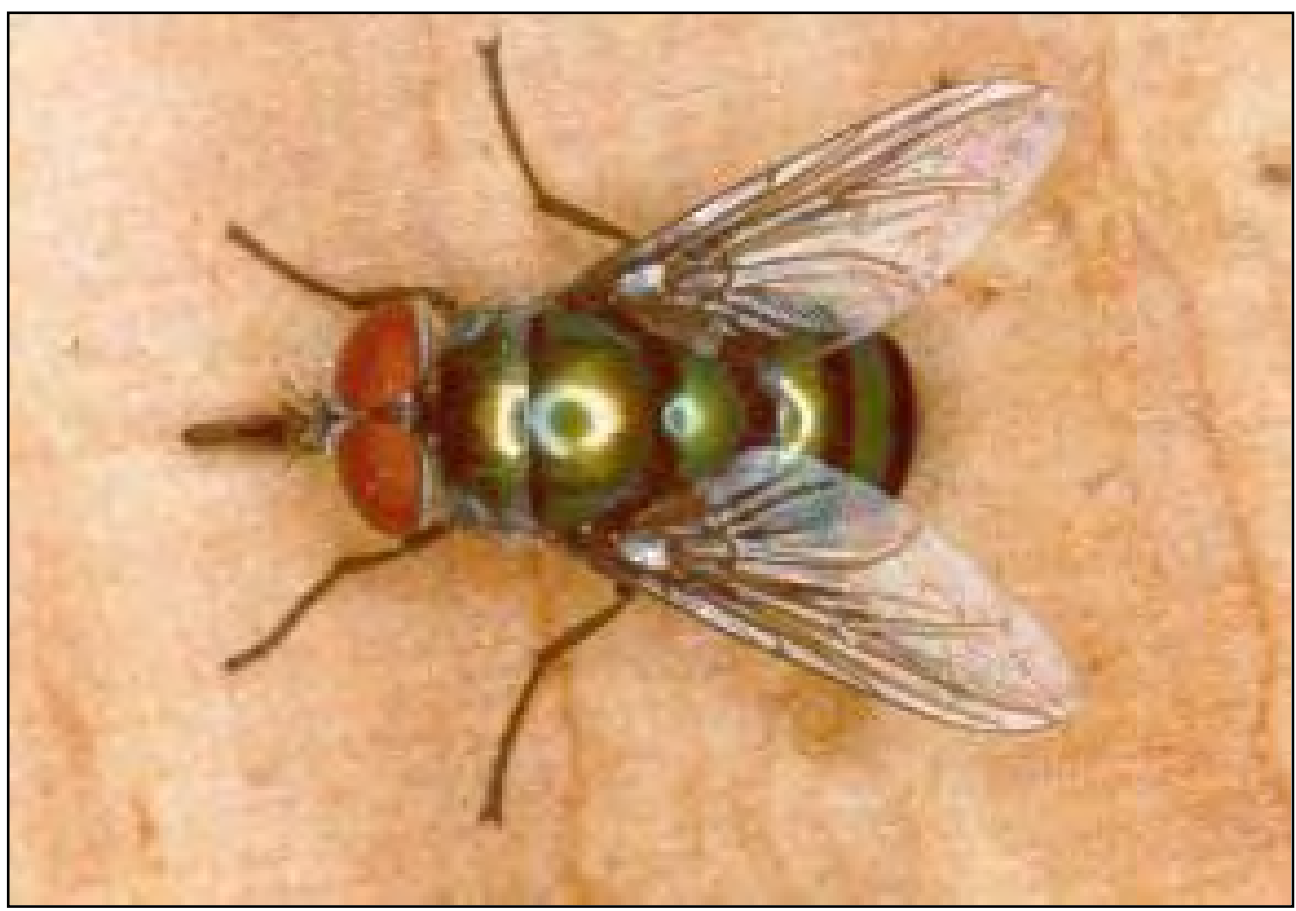

Fonte: www.spc.int/rahs/Manual/images/SWF.htm

Escala 1: 10 
Os califorídeos adultos podem ser atraídos por substâncias em processo de fermentação, decomposição, sangue e feridas. Desta forma, são encontrados em abatedouros, estábulos de gado leiteiro, frigoríficos, aviários, plantas em decomposição, lixo doméstico feiras livres, curtumes, aterros sanitários e lixão a céu aberto, e em frutos caídos. Dípteros do gênero Chrysomya possuem grande importância ecológica, veterinária e médico-sanitária, ainda, pelo seu papel como decompositores de matéria orgânica, vetores mecânicos de patógenos, produtores de miíases primárias e secundárias no homem e nos animais, além de serem de fundamental importância em entomologia forense como indicadores de tempo de decomposição de cadáveres humanos (SEOLIN DIAS, 2008).

\section{RESUltados ObTIDOS NAS ATIVIDADES do LABORATÓRIO DE GEOGRAFIA DA SAÚdE (SEOLIN DIAS E GUIMARÃES, 2008).}

Ao todo foram capturados 2406 dípteros, sendo 1629 (67,70\%) califorídeos, 19 (0,80\%) fannideos, 550 (22,90\%) muscideos, 188 (7,81\%) sarcophagideos e 20 (0,83\%) outras moscas (Fig. 7).

Os califorideos no Jardim Morada do Sol de Presidente Prudente foram mais abundantes no verão, 946 espécimes (86,23\%) do total capturado nesta estação. Na primavera foram encontrados 340 (38,72\%) espécimes, enquanto que no outono e no inverno, respectivamente, 131 (79,49\%) e 214 (80,45\%) indivíduos. Com relação aos fannideos, a população foi pequena. Verificou-se maior contagem populacional na primavera, 12 (1,36\%) espécimes. No outono foram capturados quatro (2,4\%) espécimes, no inverno três $(1,13 \%)$ indivíduos e no verão não houve registro dessas moscas. Os muscideos tiveram maior predominância na primavera, 409 (46,58\%) espécimes. No verão foram capturados 109 (9,93\%) espécimes, no inverno 24 (1,88\%) e no outono seis (3,6\%). Os sarcophagideos foram mais freqüentes na primavera, 113 (12,9\%) indivíduos. No verão, capturou-se 31 (29\%) espécimes, enquanto no inverno e outono, respectivamente, 20 (7,52\%) e seis (3,6\%) indivíduos.

Durante a investigação da primeira pesquisa, verificou-se a predominância da família Calliphoridae em todas as estações do ano. A figura 8, por estação, está representando a variação sazonal das moscas.

Os trabalhos sobre moscas apontam que os maiores picos populacionais de moscas em meses mais quentes e úmidos do ano (LINHARES, 1979; RODRIGUES-GUIMARÃES et al., 2004; VIANNA, et al., 2004, apud SEOLIN DIAS, 2008), coincidindo com os resultados do presente estudo. 


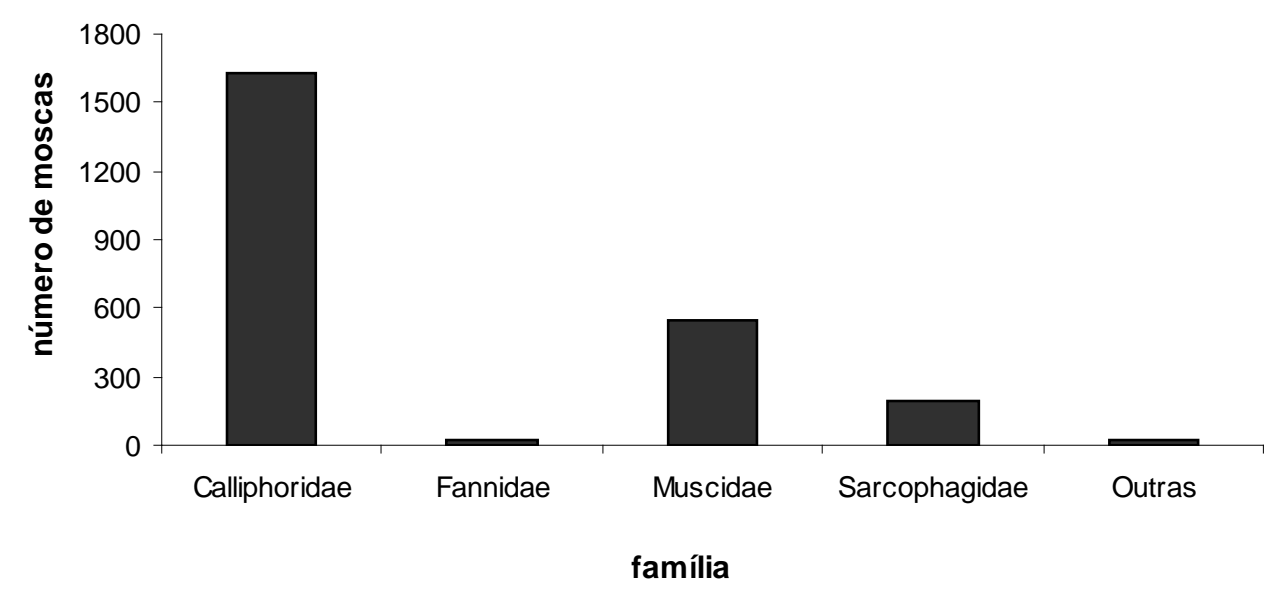

FIgURA 7. Número de moscas das famílias Calliphoridae, Fannidae, Muscidae e Sarcophagidae, no período de junho de 2007 a junho de 2008, no Jardim Morada do Sol, P. Pte., SP.

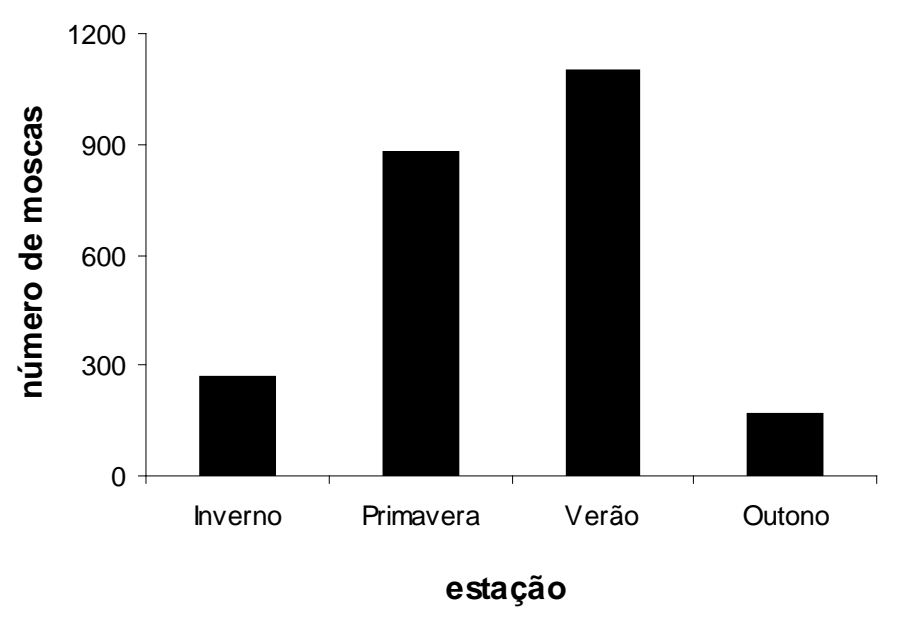

FIGURA 8. Dinâmica populacional de Calliphoridae, Fannidae, Muscidae e Sarcophagidae, no período de junho de 2007 a junho de 2008 no Jardim Morada do Sol de P. Pte., SP.

O controle de Muscídeos e Califorídeos, assim como o de outros vetores, pressupõe uma abordagem sistêmica e multidisciplinar do ambiente, incluindo os fatores antrópicos e naturais envolvidos no tempo e no espaço, sendo que, para Barcellos \& Bastos (1996, apud SANTOS, 2006), a análise espacial da saúde é complexa e supõem uma profunda compreensão e distinção entre as variáveis de saúde, seus determinantes e seus contornos sócio-econômicos. A diferenciação espacial inclui também outros aspectos da sociedade, tais como: cultura, educação, ideologia, renda, características genéticas e habitacionais, além dos fatores propriamente ambientais. 


\section{2. $O$ interesse da comunidade pela pesquisa e o início da ação educativa.}

Os insetos associados às aglomerações humanas, ditos sinantrópicos ( $\sin$ = ao redor de; anthropos $=$ homem), como os dípteros, são vulgarmente relacionados às imundícies, como esterco, excremento, lixo e matéria orgânica em decomposição. Há, contudo, algumas espécies de moscas que não se criam em locais sujos.

Mesmo assim, observamos que os estudos sobre as moscas levam as pessoas a refletirem sobre a sua saúde e sobre a saúde ambiental, muito mais do que aqueles relacionados aos mosquitos causadores de doenças (como os da dengue, malária e leishmaniose). Isto por causa da longa convivência dos seres humanos com estes insetos (as moscas), considerados não como “invasores” (como no caso dos mosquitos), mas como insetos comuns ao ambiente doméstico e supostamente inofensivos à saúde humana.

Apesar de sua proximidade, no entanto, a sensibilização para o fato de que as moscas se reproduzem em ambientes sujos, como esterco e matéria em decomposição, leva as pessoas a associarem a sua presença com a imundície, mexendo com a imagem que o indivíduo faz de si próprio, e do ambiente em que vive. E a imundície é facilmente associada à doença.

Com os mosquitos é diferente: seu extermínio decorre de ações que colocam as pessoas na defensiva, quando não percebem o verdadeiro significado delas para a sua saúde: simplesmente não entendem que mal pode advir de alguma quantidade de água limpa represada, e de um monte de folhas secas deixadas sobre o solo no quintal, prática corriqueira utilizada para adubar a terra.

Há que se levar em conta neste aspecto, também, o fato de que a abordagem relativa aos mosquitos hematófagos transmissores de doenças geralmente é realizada por órgãos de saúde pública municipais, através da distribuição de cartilhas e panfletos cuja elaboração ocorre baseada na "pedagogia do medo": os mosquitos são desenhados em tamanho desmesuradamente maior do que o normal, assemelhando monstros perigosos, e as mensagens redigidas em tom de ameaça. As palestras realizadas tampouco minimizam esta abordagem, contribuindo para que o conhecimento a esse respeito não seja incorporado pelas pessoas: não são possibilitadas as oportunidades para as perguntas e discussões em torno do assunto; o palestrante simplesmente transmite as informações, geralmente em linguagem científica e empregando jargões técnicos, que pouco ou nada significam para os ouvintes de origem humilde e com baixa escolaridade.

A aversão natural às moscas é agravada com o seu aumento ocasionado por atividades agropecuárias localizadas nos limites da área urbana, como as granjas, pocilgas, estrebarias, cocheiras, currais etc. O controle das moscas pode ser muito complicado, devido à grande 
mobilidade dos insetos adultos e à grande facilidade com que adquirem resistência aos mais diversos tipos de inseticidas.

É salutar destacar que a simples presença da Universidade em uma comunidade já é capaz de alterar sua rotina. Assim foi quando iniciamos a colocação das armadilhas para a coleta das moscas - ao simples mencionar do nome da Universidade, as pessoas já inferiam tratar-se de algo importante.

A curiosidade a respeito da pesquisa levava sempre ao questionamento: o quê estava sendo feito? Por quê? Por que naquele bairro? E, finalmente, quando a Universidade proporcionaria condições para que entendessem um pouco mais sobre aquela pesquisa? Alguns moradores entusiasmaram-se com a pesquisa, tomando conta das armadilhas, que eram constantemente alvo da curiosidade das crianças. Um morador chegou ao ponto de monitorar a quantidade de moscas que entravam e saíam da armadilha durante um dia inteiro!

Mas, o mais importante a considerar foi a oportunidade dada à comunidade de inteirar-se do conhecimento produzido pela pesquisa, além de participar da ampliação dele, através do aumento de sua abrangência e demais desdobramentos proporcionados pela pesquisa sobre as moscas.

Para implementar as investigações em saúde ambiental desenvolvida pela presente pesquisa (Quadro 2), consideramos que o sistema de intervenção e de estudos das questões que relacionam a saúde ao ambiente é um sistema aberto e dinâmico, incorporando a sua historicidade e subjetividade aos contextos onde ocorrem os processos interdependentes que conformam os problemas sócio-ambientais. Tendo essa referência como ponto de partida, trabalhamos os problemas sem perder de vista que não se trata apenas de questões acadêmicas, mas que envolvem a relação entre a universidade e os serviços de saúde, numa perspectiva interdisciplinar e na busca de soluções e de novas possibilidades que permitam a melhoria da vida das pessoas. Uma alternativa estratégica para esta abordagem parece ser a incorporação ampla da sociedade na discussão de seus problemas e ir além, captar como a comunidade vê o mundo, uma vez que ela o vê de forma integrada. Para isto necessitamos de vários paradigmas e não apenas de um ponto de vista (AUGUSTO et al, 2003).

Nesse sentido, as pesquisas que lancem a oportunidade de reunir saberes interdisciplinares e procurem identificar, junto às comunidades, quais as formas mais adequadas para a prevenção e a promoção de sua própria saúde enquadram-se neste novo rol de investigação científica interessada em romper com antigos paradigmas investigativos e buscar uma compreensão mais ampla acerca do meio ambiente, das ações humanas e suas conseqüências e, sobretudo, do próprio homem. 
O ato de "estar" no bairro é bem diferente de "conviver" nele. As meras "visitas" investigativas não dão conta de apreender o que aflige as pessoas, o que elas sentem e pensam sobre aquilo que mais afeta suas vidas e sua saúde. A abertura para o estabelecimento deste vínculo entre a Universidade e a comunidade dos bairros pesquisados sempre foi o caminho metodológico seguido pelo Laboratório de Geografia da Saúde: as coletas dos dípteros eram normalmente realizadas com tempo suficiente para conversar com as pessoas, averiguar o que as preocupava, observar suas reações à pesquisa, captar o que elas queriam a partir da investigação e, no dizer de Paulo Freire (1987), ad-mirar o espaço em torno e as pessoas nele buscando, sobretudo, a essência daquela relação, para além das aparências.

QUADRo 2. PESQUISA-AÇÃo.

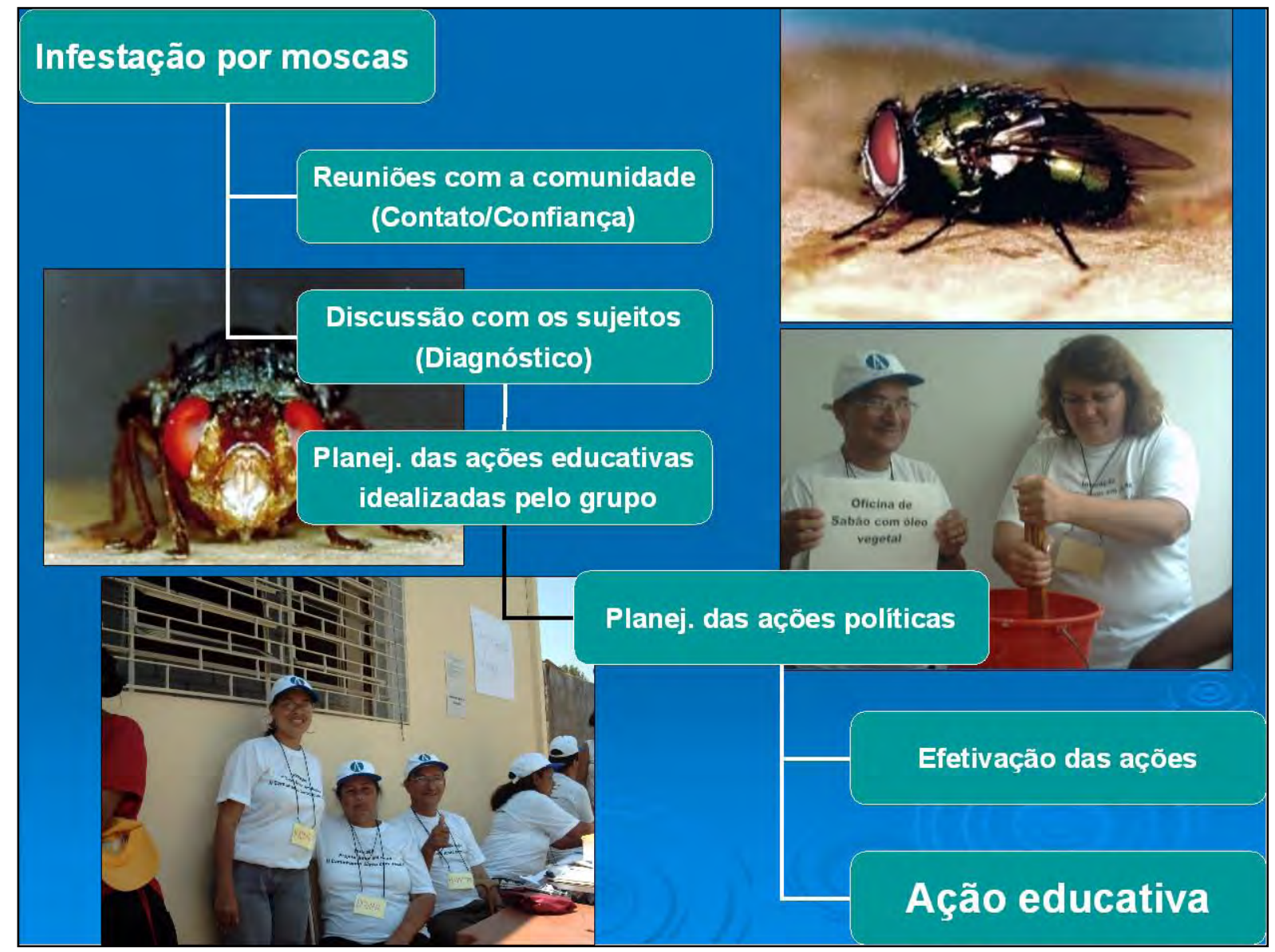

Org.: Torrezan, R. M., 2008

Através desta postura investigativa é que surgiu a oportunidade de diálogo, de conversar, de conviver e de reunir-se, a fim de criar meios para o desenvolvimento das ações educativas em saúde, pensando as possíveis soluções junto com a comunidade. E as relações de afetividade não ficaram de fora: a amizade das pesquisadoras com pessoas da comunidade, e 
outras que trabalham nos bairros e se consideram parte deles, ampliaram os ganhos registrados com esta parceria.

Participando das reuniões comunitárias, compartilhando seus percalços, típicos do início de uma jornada coletiva pela conquista de seus direitos, e compartilhando também seus avanços, demos a partida para o entendimento do que a comunidade considerava adequado para a obtenção dos melhores resultados em educação para a saúde em seus bairros. 
Capítulo 3. Pesquisa-aÇÃo.

AÇÃO EDUCATIVA EM SAÚDE.

\section{Eu sou feliz}

Eu venho participar Com toda essa emoção Juntos temos que lutar Com amor no coração

Eu sou feliz

E na comunidade Na comunidade

Eu sou feliz

Eu já passei do passado Agora vivo o presente Pois agora eu sou feliz $E$ que ninguém fique ausente

Eu sou feliz É na comunidade Na comunidade Eu sou feliz

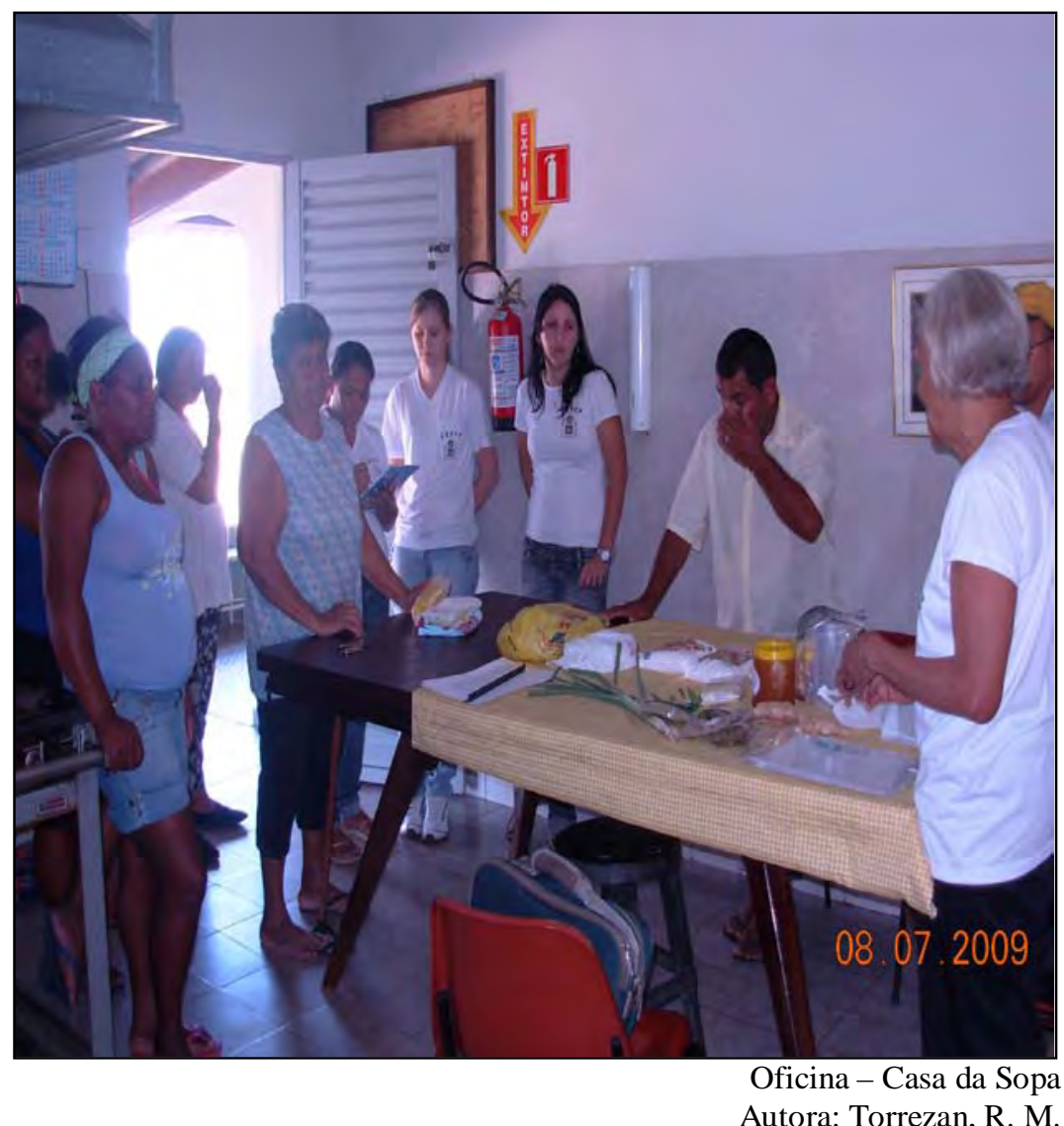

(Poema escrito por um dos participantes da Governança Local, morador do Residencial Francisco Belo Galindo, em 04/09/2008). 
Na segunda fase da pesquisa, deu-se início à participação efetiva nas reuniões de Desenvolvimento Local (coordenadas pela Agente de Desenvolvimento Local do Senac Cláudia V. Garcia Dias), e realizadas na Casa da Sopa, tendo esta fase sido iniciada em março de 2009.

As participações em reuniões anteriores, no decorrer do ano de 2008 (Fotos 1 e 2), não se encontram aqui documentadas com detalhamento por terem se tratado de experiências exploratórias de participação; no entanto é mister considerar que estas primeiras reuniões foram extremamente úteis para obter um maior contato com os participantes e a comunidade, angariando maior confiabilidade, sem a qual o trabalho junto a estas pessoas se tornaria inviável.

Nas reuniões iniciais foram realizadas atividades interativas, proporcionando às pessoas do grupo conhecerem-se melhor e adquirirem confiança e desenvoltura para estabelecer o diálogo. Foram realizadas também atividades de campo para reconhecimento do bairro (Figuras 9 e 10), a fim de serem anotadas as principais características, pontos importantes para a comunidade e atividades econômicas desempenhadas pelas pessoas do bairro.

A verdade é que não sabíamos até que ponto as Reuniões de Desenvolvimento Local seriam úteis ao que estávamos dispostos a propor para a comunidade. Não tínhamos idéia das dinâmicas que estavam sendo utilizadas, ou se haveria abertura para a inserção de assuntos de interesse direto com a nossa pesquisa. Contudo, estas experiências iniciais nos deram a certeza de sermos bem acolhidos, e percebemos que a receptividade é uma das principais marcas desta comunidade. No final do ano de 2008, após o período inicial de adaptação à forma de condução das reuniões, tivemos a certeza de que poderíamos iniciar um bom trabalho em 2009, contando com a abertura generosa e cooperativa do Senac, da comunidade e da Casa da Sopa.

Foram dezessete reuniões de Desenvolvimento Local (Quadro 3), e cerca de dez reuniões paralelas (com a responsável pelo Projeto Sócio-Ambiental do Senac; com os agentes de saúde, a enfermeira-chefe e a médica do PSF; a professoras, coordenadora e diretora da EMEIF; e com membros das Pastorais da Criança e da Família atuantes no bairro), além de outras atividades desenvolvidas no bairro (Quadro 4).

Além das reuniões, que visaram a integração das idéias e das ações a serem desenvolvidas em educação e saúde, de forma conjunta e garantindo seu caráter interdisciplinar e intersetorial, houve a participação em outras ações planejadas e implementadas pela Governança Local em parceria com o Senac. 
FOTO 1. Reunião de Desenvolvimento Local - Casa da Sopa - 2008.

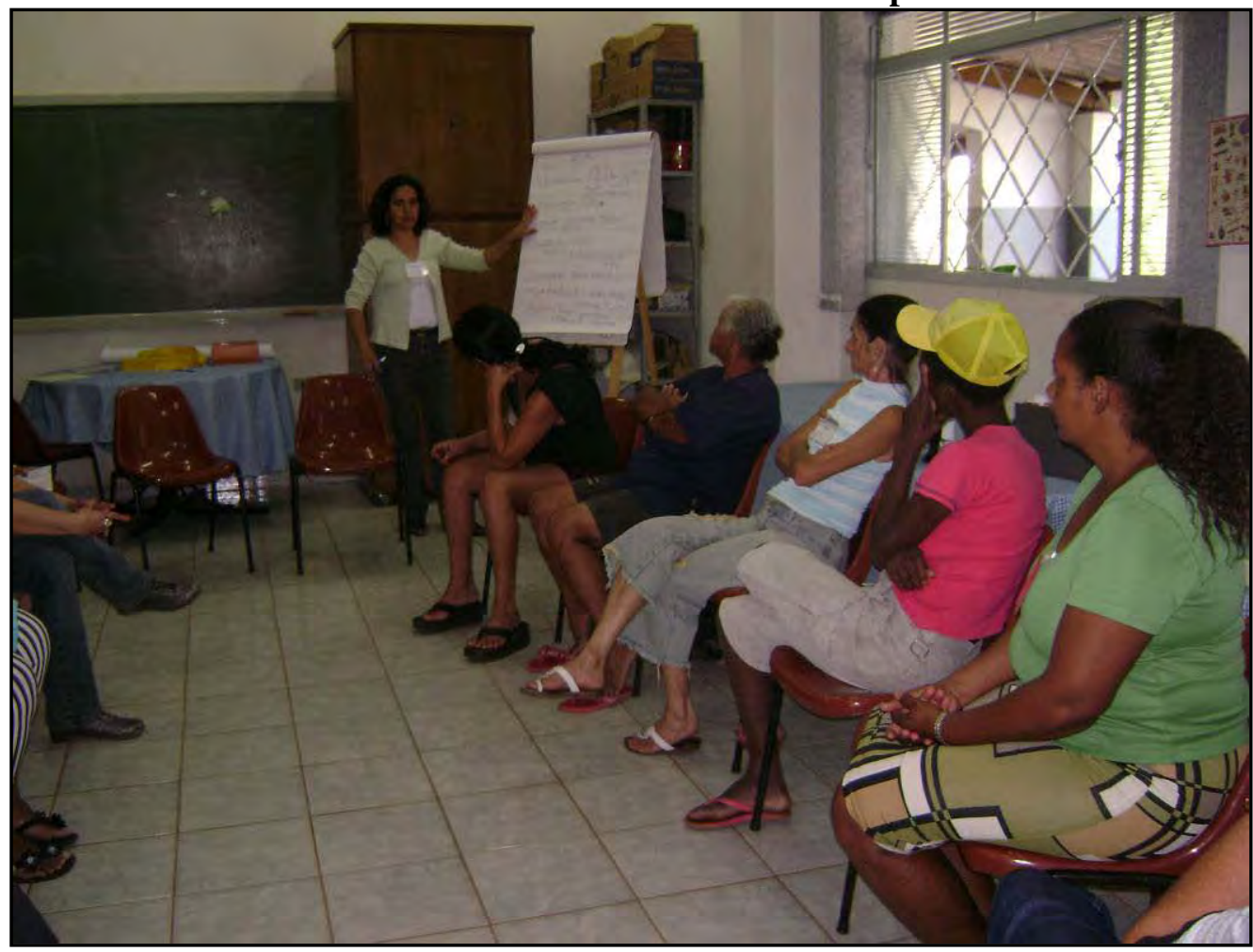

Autora: Torrezan, R. M.

FOTO 2. A comunidade sai a campo - Jd. Morada do Sol. - 2008.

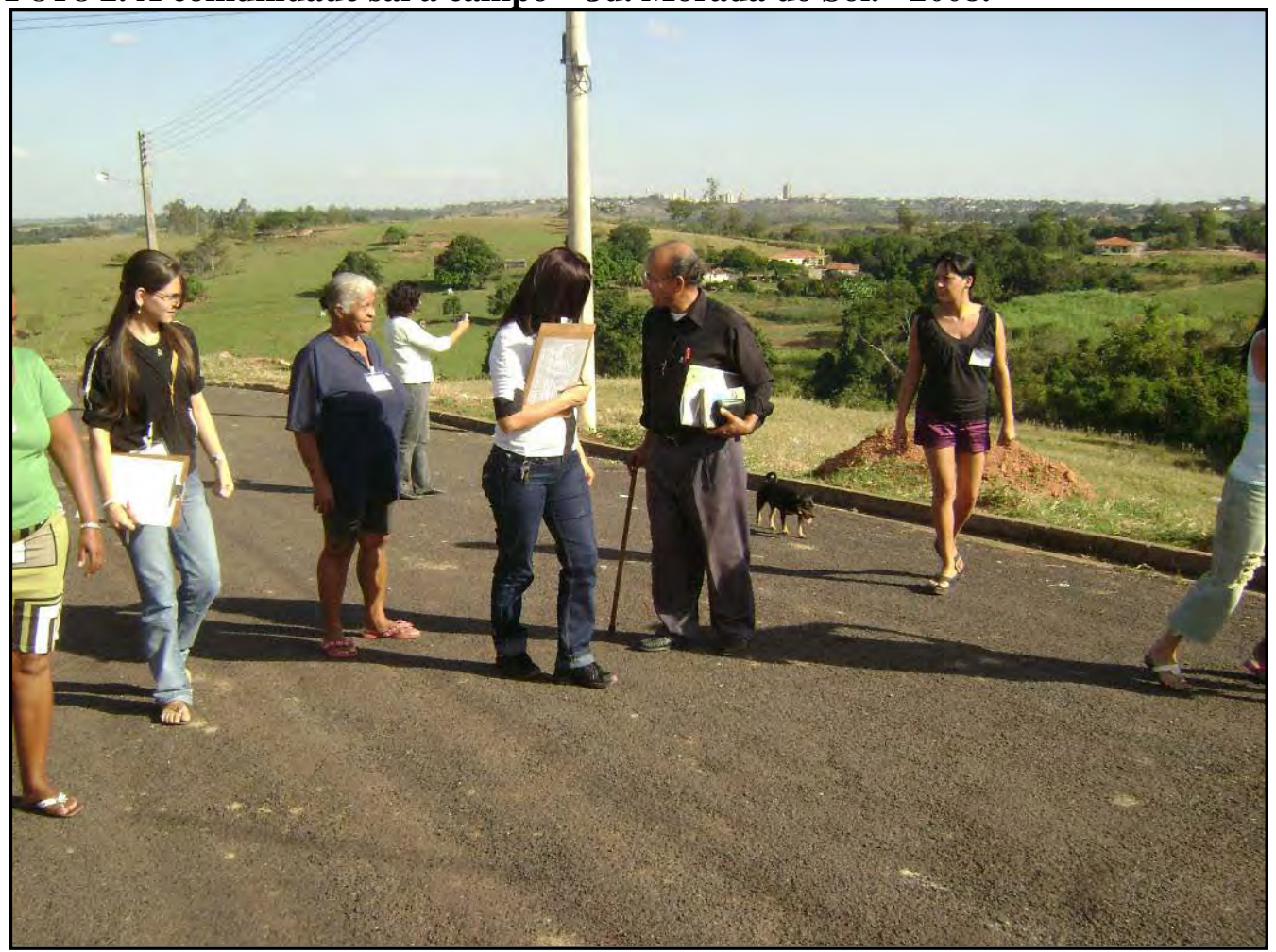

Autora: Torrezan, R. M. 
FIGURA 9. Mapa desenhado por morador (Pque. Res. Francisco Belo Galindo).

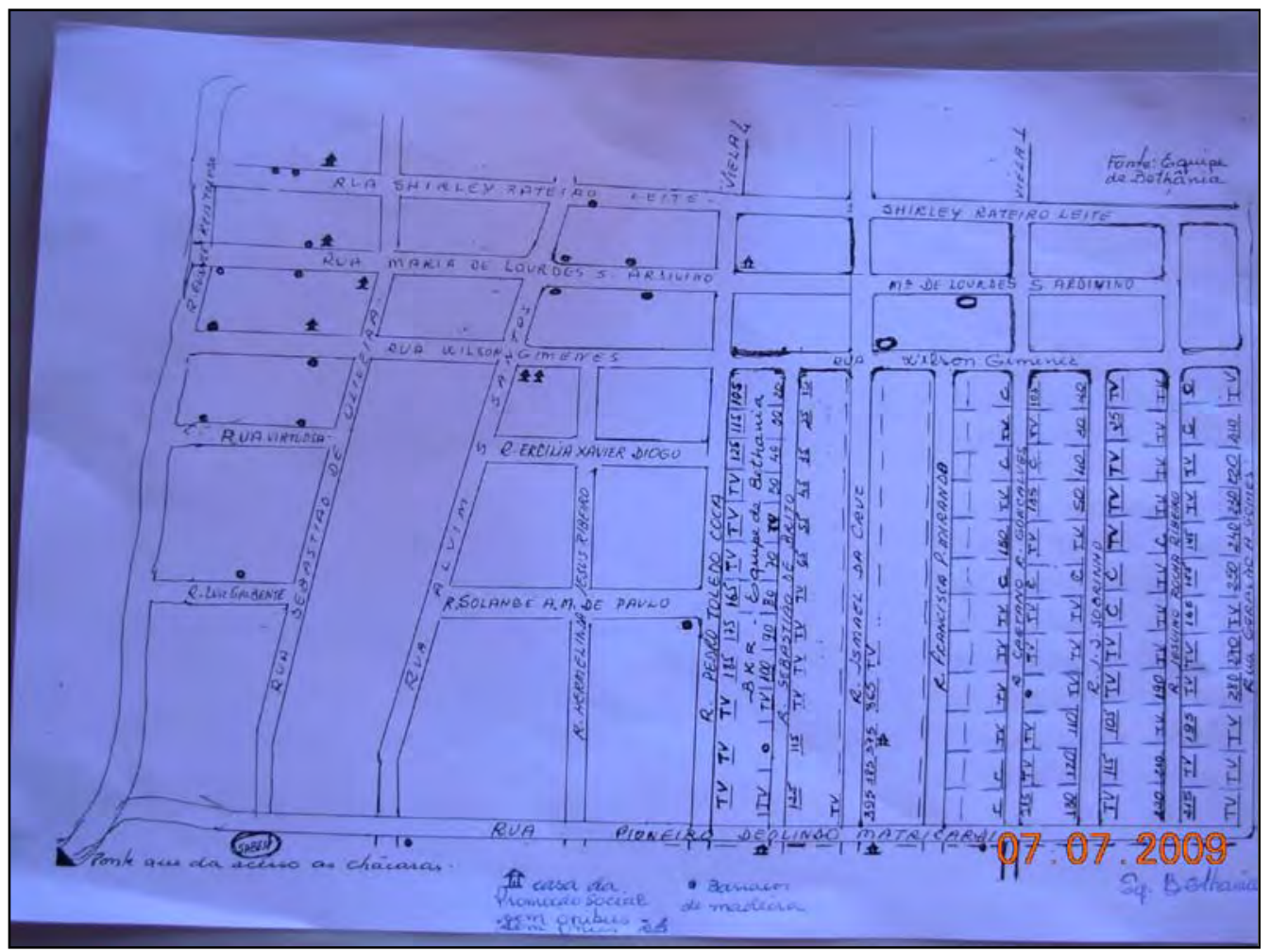

FIGURA 10. Mapa desenhado por morador (Pque. Res. Francisco Belo Galindo).

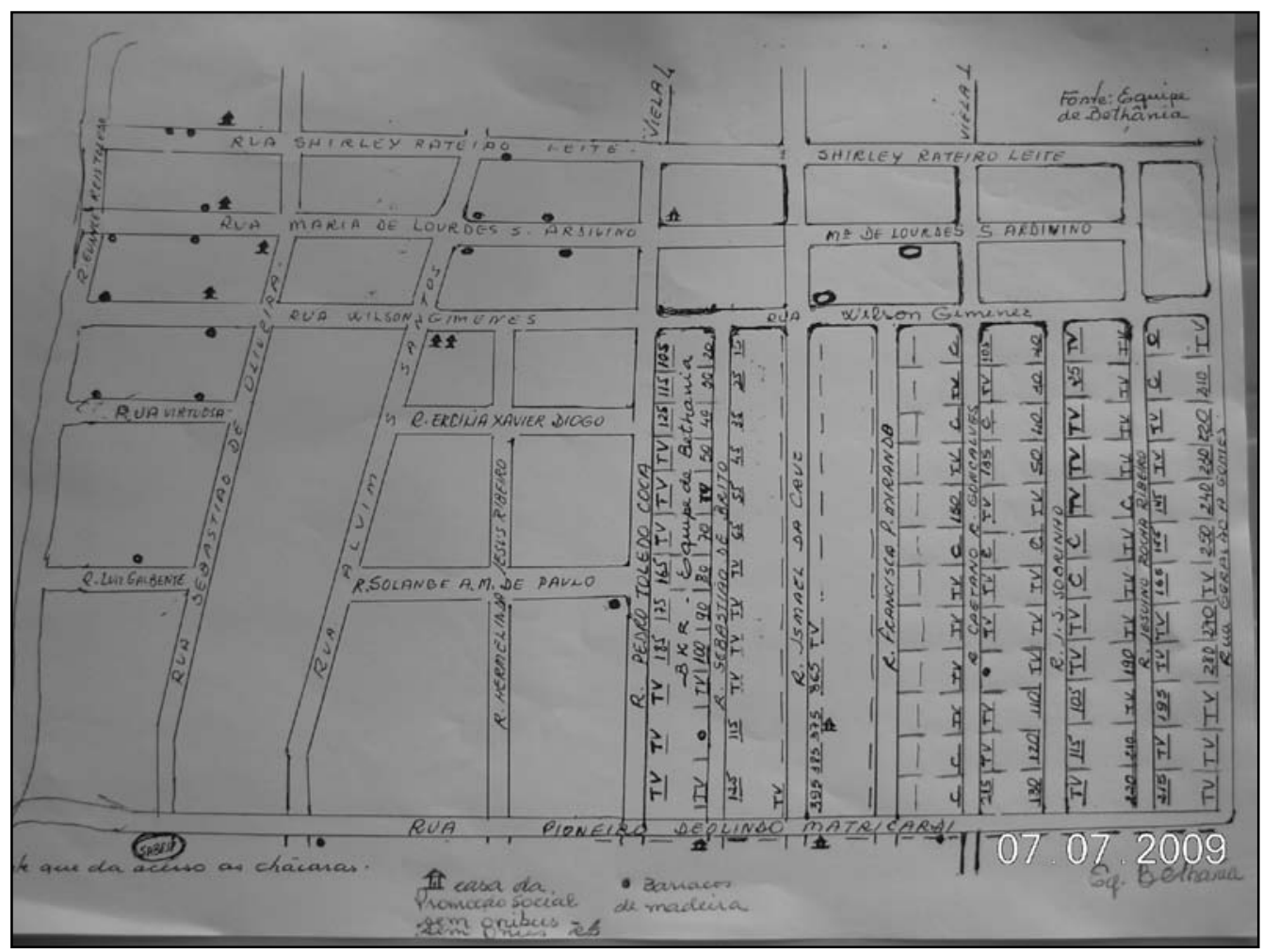

Fonte: trabalho de campo, 2009

Autora das fotos: Torrezan, R. M. 
Os mapas constituíram parte importante destas atividades. Eles foram elaborados nas atividades de campo durante as reuniões de Desenvolvimento Local, quando a comunidade saía às ruas identificando os terrenos baldios, pequenos comércios importantes para a comunidade, locais onde se jogavam entulhos, etc., tanto no Jardim Morada do Sol quanto no Parque Residencial Francisco Belo Galindo. Temos assim, nestes mapas, o reconhecimento que os próprios moradores fizeram de seu bairro.

Percebemos a dimensão da importância estratégica das informações colhidas pelos moradores in loco, quando os mapas do Jardim Morada do Sol confeccionados pelos moradores foram levados por um futuro candidato a vereador, emprestados para a elaboração de sua de campanha, e nunca mais foram devolvidos.

Embora o “cartógrafo” oficial fosse o Sr. Braulino (que em suas andanças pelo bairro aperfeiçoava de forma detalhada as informações), a verdade é que os moradores também contribuíam, apontando eventuais falhas ou acrescentando algum ponto. Muitos deles integram o grupo religioso pertencente à Igreja Católica denominado Equipe de Bethânia, e que assina a confecção do mapa.

As anotações sobre os lugares onde se desenvolviam atividades religiosas (Igrejas, locais de culto, etc.) sofreram desfalque, devido ao fato da maioria delas não possuir sede própria, e por isto se deslocarem com freqüência.

Vê-se, nos dois mapas acima (figuras 9 e 10), a nomeação correta das ruas do bairro Parque Residencial Francisco Belo Galindo, a localização dos pontos de ônibus e a localização dos barracos de madeira. Os terrenos vazios (tv, no mapa) também foram anotados. Observa-se nos mapas, entretanto a grande falha desta informação. Isto ocorreu porque grande parte dos lotes deste bairro ainda não possui edificações, ficando difícil aos moradores distinguir quais eram as áreas de lotes e as destinadas ao uso público. Isto foi corrigido posteriormente, na confecção do mapa final, infelizmente quando nosso trabalho já havia chegado a termo.

\subsection{O SENAC E A CASA DA Sopa.}

Nosso trabalho foi realizado conjuntamente com as atividades de Desenvolvimento Local realizadas pela entidade assistencial Casa da Sopa e pelo Senac de Presidente Prudente ${ }^{7}$. Participam das reuniões moradores dos dois bairros (Jardim Morada do Sol e Francisco Belo

\footnotetext{
7 O Senac (Serviço Nacional de Aprendizagem Comercial) é uma entidade nacional autônoma, de direito privado, criada através do Decreto Lei n 8.621, em 10 de janeiro de 1946, mantida e administrada pelo comércio e serviços (setor terciário). O Senac é considerado referência nacional em educação profissional.
} 
Galindo), assistentes sociais, funcionários e representantes de entidades assistenciais, pesquisadores, professoras que trabalham no bairro, representantes da Associação de Moradores e a coordenadora do Programa de Desenvolvimento Local do Senac, perfazendo uma média de 10 a 20 pessoas por reunião.

O Programa de Desenvolvimento Local tem como objetivo induzir o desenvolvimento nas localidades em que o Senac São Paulo está presente e atua. Faz isso por meio de uma metodologia com foco na formação e instrumentalização do capital social dessas comunidades. O objetivo é passar de um configurado cenário para outro melhor e sustentável, que gere crescimento econômico, promova o desenvolvimento social e preserve o meio ambiente, sempre considerando as gerações atuais e futuras.

Envolve mobilização e articulação de atores sociais na criação de governança local, elaboração da visão de futuro para os próximos 10 anos, diagnóstico participativo e plano de desenvolvimento que direcione ao futuro desejado.

Este desenvolvimento deve ser planejado de forma coletiva e integrado entre todos os setores da sociedade. Para iniciar esse processo investe-se em capital social, por meio das redes sociais, que devem estar fortalecidas e coesas. Com o consenso de seus participantes, é constituída uma comissão de desenvolvimento local, responsável pela escolha do local em que o processo será fomentado.

O Senac São Paulo entende o desenvolvimento local como uma estratégia que considera o desenvolvimento de comunidades identificadas geograficamente por seus recursos e potencialidades. Portanto, considera que falar de desenvolvimento local é falar do desenvolvimento das pessoas e de suas comunidades.

Acreditando nisso, a instituição tem dado ênfase a dois métodos de trabalho em nível local: o Programa Rede Social, que fomenta e promove ações em rede, e o Programa de Desenvolvimento Local, iniciado em 2004, a partir da experiência com as redes sociais, que motivou a criação de uma metodologia de indução ao desenvolvimento local. Estratégias diferentes são implementadas para cada situação, mas o ponto fundamental é a capacitação em redes e desenvolvimento que cria o ambiente favorável à governança e demais passos do processo, como visão de futuro, diagnóstico participativo e plano de desenvolvimento.

Hoje, o Programa é desenvolvido em 51 localidades do Estado de São Paulo. Neles, a governança já está formada. A maior parte já definiu sua visão de futuro para os próximos 10 anos e está trabalhando na realização dos diagnósticos participativos, como forma de identificar o mapa dos ativos e necessidades locais, com os seus respectivos cenários e sugestões de 
melhoria. A cidade de Águas de São Pedro foi pioneira na realização do diagnóstico, que foi incorporado ao plano diretor do município como leitura comunitária, e que será votado em breve pelos vereadores para orientar as definições das políticas públicas da cidade.

A ONG Casa da Sopa Francisco de Assis (CASOFA) Associação Assistencial e Educacional Espírita, presta atendimento aos moradores do bairro Jardim Morada do Sol e Residencial Francisco Belo Galindo há dezessete anos, desde a sua fundação. A CASOFA, como é conhecida, dispõe de biblioteca, consultório médico e odontológico e laboratório de informática, oferecendo atendimento de qualidade à comunidade por vários profissionais voluntários. A organização oferece ainda à comunidade atividades de incentivo à educação, dança, arte e cultura, proporcionando um espaço de participação e fortalecimento das relações sociais dos moradores do bairro.

Foto 3. Casa da Sopa Francisco de Assis - Jd. Morada do Sol.

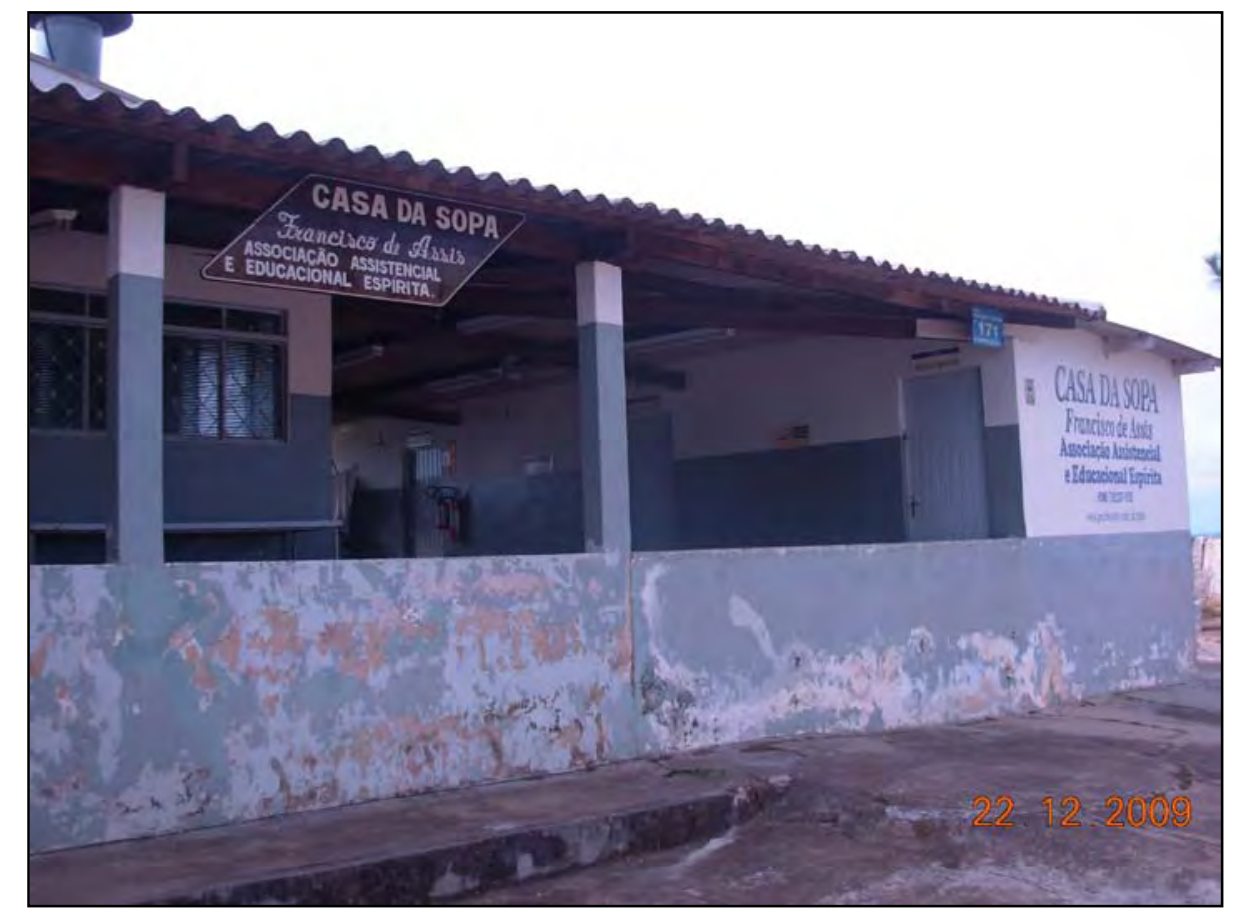

Autora: Torrezan, R. M.

O Projeto de Desenvolvimento Local é fruto de uma parceria entre a entidade assistencial e educacional espírita Casa da Sopa e o SENAC de Presidente Prudente, visando a realização e o desenvolvimento de uma série de instrumentos construtores da cidadania participativa, como a Governança Local, o Diagnóstico Participativo e a definição da Agenda de Prioridades, sempre contando com a colaboração de uma Rede Social formada por profissionais (voluntários ou não), pessoas da comunidade e pesquisadores de Universidades. 
- A Governança Local é a força política que se constrói em torno de pactos, entre atores sociais, para a realização de ações e projetos que promovam o desenvolvimento local. O desenvolvimento objetivado é o das pessoas, no sentido de alcançarem uma vida melhor e um melhor convívio. Esse núcleo comunitário, a Governança, é formado por pessoas expressivas da sociedade civil e dos setores governamental e empresarial, que produzem e constituem, ao mesmo tempo, o capital social que se quer incrementar. Esse "governo” local se orienta por uma participação igualitária e democrática e busca a soluções de conflitos, por meio de consensos, além de garantir a transparência e disseminação das informações e do processo de desenvolvimento econômico, que beneficie as pessoas e preserve o meio ambiente.

- O Diagnóstico Participativo é uma dinâmica, uma forma como as pessoas da comunidade reconhecem e apreendem mais sobre os recursos disponíveis e equipamentos, em termos de saúde, educação, economia, cultura, lazer e condições do meio ambiente para a população. É realizado depois da “Visão de Futuro” para que a comunidade saiba, por meio dos mapas de ativos e necessidades, com o quê conta, e que necessidades precisam ainda ser atendidas para chegar ao futuro idealizado. Locais onde se elaboram ou se atualizam Planos Diretores podem utilizar-se desta ferramenta ou dos registros do diagnóstico participativo para a formulação da Leitura Comunitária.

- O Plano de Desenvolvimento constitui a ferramenta por onde se definem as Metas e a Agenda de Prioridades. O Plano é elaborado na forma de um mapa do caminho para o futuro onde os marcos de referência são as realizações para superação dos obstáculos e para o aproveitamento das oportunidades, baseadas, fundamentalmente, na utilização dos próprios ativos (na capacidade interna de investir nesses ativos e na capacidade de atrair investimentos externos). A Agenda de Prioridades é uma listagem das ações prioritárias que deverão ser realizadas, no período de um a dois anos e incorpora também outras ações do poder público ou da sociedade local que estejam em curso ou previstas. O Plano deverá ser celebrado por um Pacto Local que formaliza os compromissos assumidos por todos os participantes da governança, parceiros, governo, empresários e sociedade civil.

Nossa pesquisa contribui para a elaboração do Plano no que concerne à educação para a saúde, visando à prevenção de doenças e à melhoria das condições gerais de saúde da população. Atende-se, neste caso, a uma demanda coletiva local pela ação educativa, procurando envolver diferentes atores e espaços, suscitada pelo trabalho de monitoramento da infestação por moscas domésticas realizado pelo Laboratório de Geografia da Saúde da UNESP de Presidente Prudente.

Desta forma, ocorreu a participação no “Mutirão de Limpeza” realizado nos dois bairros (Jd. Morada do Sol e Residencial Francisco Belo Galindo). 
FOTO 4. Confraternização: Reunião de Des. Local - Casa da Sopa - 2008.

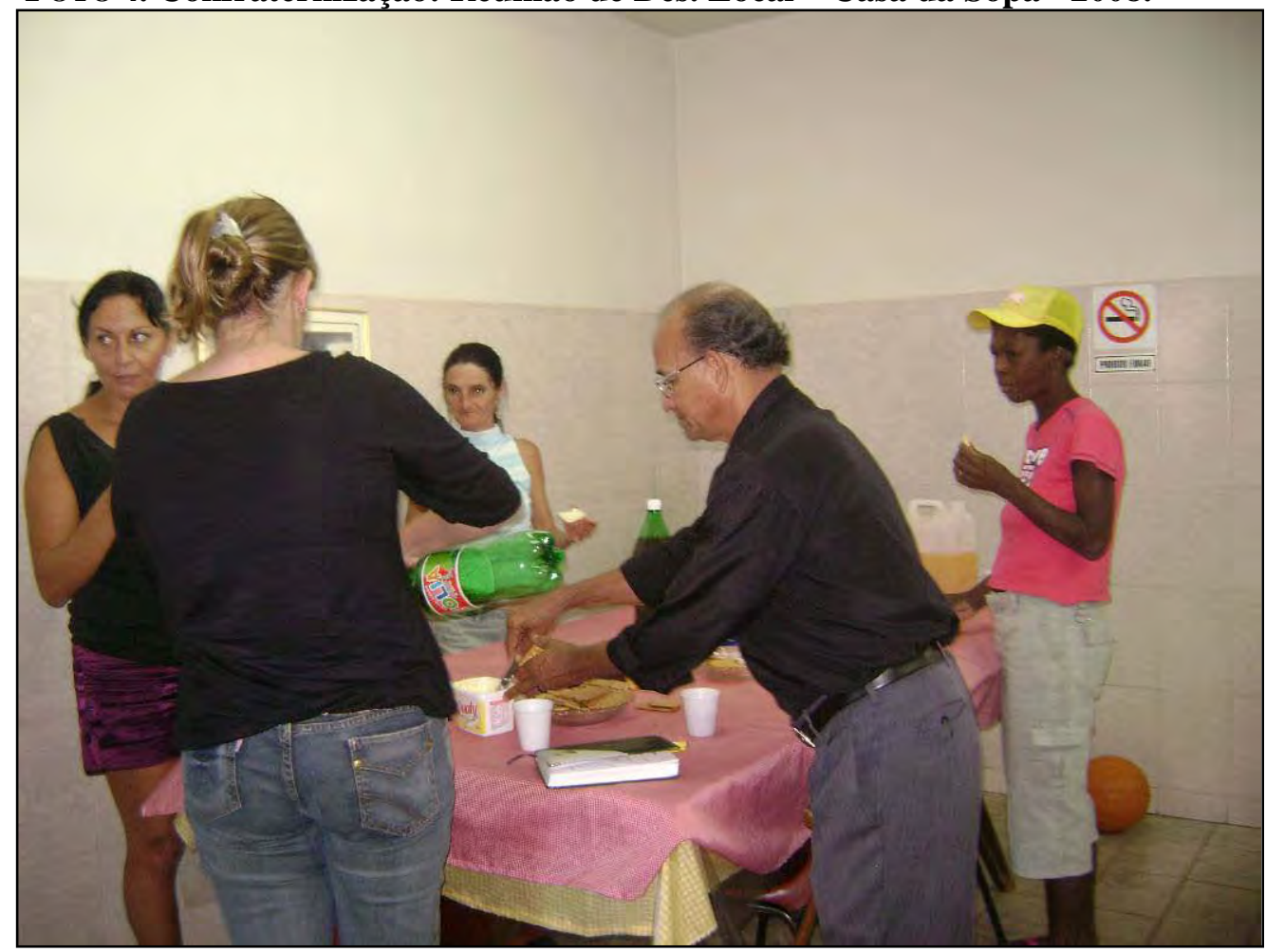

FOTO 5. Reunião de Desenvolvimento Local - Casa da Sopa - 2008.

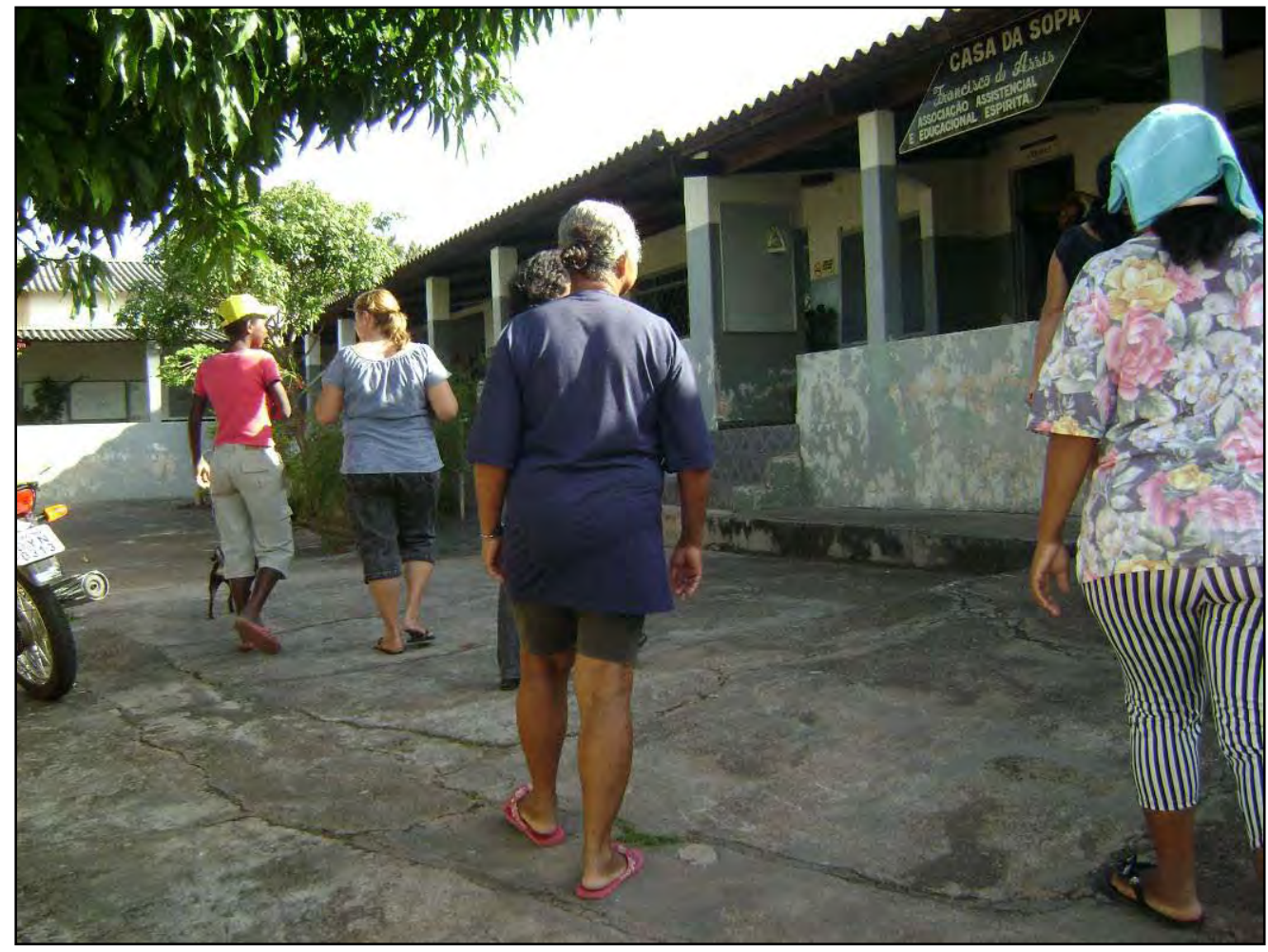

Autora: Torrezan, R. M. 


\begin{tabular}{|c|c|c|}
\hline \multicolumn{3}{|r|}{ QUADRO 3} \\
\hline \multicolumn{3}{|r|}{ REUNIÕES DE DESENVOLVIMENTO LOCAL (2009) } \\
\hline & DATA & AssunTO \\
\hline 1. & $13 / 03$ & $\begin{array}{l}\text { O Mutirão de Limpeza: presença da Vigilância Sanitária; discussão sobre a realização de } \\
\text { um Arrastão ou um Mutirão. }\end{array}$ \\
\hline 2. & $18 / 03$ & Discussão sobre a inclusão do nome de um vereador no panfleto sobre o Mutirão. \\
\hline 3. & $20 / 03$ & Capacitação para o Mutirão: palestra da Vigilância Epidemiológica. \\
\hline 4. & $21 / 03$ & Panfletagem para o Mutirão de Limpeza. \\
\hline 5. & $25 / 03$ & Apresentação dos resultados da pesquisa sobre as moscas. \\
\hline 6. & $15 / 04$ & Avaliação dos resultados do Mutirão. \\
\hline 7. & $22 / 04$ & Presença da Arquitetura da UNESP: projeto para melhorias no bairro. \\
\hline 8. & $29 / 04$ & $\begin{array}{l}\text { Participação das enfermeiras-chefes do Núcleo de Hemoterapia de P. Pte. e do PSF do } \\
\text { bairro; enquête sobre o esporte nos bairros. }\end{array}$ \\
\hline 9. & 06/05 & $\begin{array}{l}\text { Discussão da } 1^{\text {a }} \text { proposta de questionário sobre saúde ambiental. Elaboração das } \\
\text { reivindicações para esportes no bairro. }\end{array}$ \\
\hline 10. & $13 / 05$ & $\begin{array}{l}\text { Apresentação e discussão do Projeto de Esporte para os bairros; sugestões para o } \\
\text { questionário. }\end{array}$ \\
\hline 11. & $20 / 05$ & Reavaliação e rediscussão da $2^{\mathrm{a}}$ proposta de questionário sobre saúde ambiental. \\
\hline 12. & $27 / 05$ & Definição das estratégias educativas em saúde. Revisão final do questionário. \\
\hline 13. & 03/06 & $\begin{array}{l}\text { Apresentação do Projeto “Esporte e Lazer: Qualidade de Vida no Jd. Morada do Sol e } \\
\text { Res. Francisco Belo Galindo”. Presença dos representantes das Secretarias de Obras, de } \\
\text { Esportes, Meio Ambiente e Assuntos Viários. Sarna e piolho, higiene e saúde. }\end{array}$ \\
\hline 14. & 09/06 & Acertos para os últimos detalhes da $1^{\text {a }}$ Oficina de educação para a Saúde Ambiental. \\
\hline 15. & $17 / 06$ & $\begin{array}{l}\text { Avaliação da Oficina. Apresentação dos questionários impressos. Discussão da melhor } \\
\text { forma de aplicação dos questionários sobre saúde ambiental. }\end{array}$ \\
\hline 16. & $24 / 06$ & $\begin{array}{l}\text { Apresentação do Projeto de Economia Solidária pelos alunos da Geografia da UNESP. } \\
\text { Discussão e definição deste projeto (Horta Comunitária). }\end{array}$ \\
\hline 17. & $01 / 07$ & $\begin{array}{l}\text { Conversa sobre a realização da } 2^{\text {a }} \text { Oficina de Educação para a Saúde. Discussão sobre a } \\
\text { relação entre as grandes empresas de remédios e a proibição do ensino de remédios } \\
\text { caseiros às comunidades carentes. }\end{array}$ \\
\hline
\end{tabular}




\section{QUADRO 4}

OUtras Atividades ReAlizadas - REUniões PARALELAS, Oficinas, COLÓQUio (2009).

\begin{tabular}{|c|c|c|c|c|}
\hline & DATA & ATIVIDADE & LOCAL & AssunTO \\
\hline 1. & $23 / 07$ & $\begin{array}{l}\text { Atividade } \\
\text { educativa }\end{array}$ & CRAS & Atividade educativa com os alunos do CRAS. \\
\hline 2. & $25 / 03$ & Colóquio & $\begin{array}{c}\text { Casa da } \\
\text { Sopa }\end{array}$ & Apresentação dos resultados da pesquisa sobre as moscas. \\
\hline 3. & $28 / 03$ & Mutirão & Bairros. & $\begin{array}{l}\text { Mutirão de Limpeza no Jardim Morada do sol e Residencial Francisco } \\
\text { Belo Galindo. }\end{array}$ \\
\hline 4. & $04 / 05$ & Reunião & $\begin{array}{c}\text { Casa da } \\
\text { Sopa }\end{array}$ & Elaboração conjunta do questionário sobre saúde ambiental. \\
\hline 5. & $19 / 05$ & Reunião & PSF & $\begin{array}{l}\text { Revisão do questionário; reunião com a enfermeira-chefe do PSF para } \\
\text { discussão sobre a possibilidade de aplicação dos questionários pelas } \\
\text { agentes de saúde. }\end{array}$ \\
\hline 6. & $19 / 05$ & Reunião & EMEIF & $\begin{array}{l}\text { Contato com a diretora a fim de estabelecer parceria com a Governança } \\
\text { Local. }\end{array}$ \\
\hline 7. & $01 / 06$ & Reunião & EMEIF & $\begin{array}{l}\text { Reunião com a responsável pelo Projeto sócio-ambiental do Senac, e } \\
\text { com a diretora e as professoras da EMEIF sobre a Oficina. }\end{array}$ \\
\hline 8. & $02 / 06$ & Reunião & $\begin{array}{l}\text { Casa da } \\
\text { Sopa }\end{array}$ & $\begin{array}{l}\text { Reunião com as representantes do CRAS e do Senac para a elaboração } \\
\text { da versão final do Projeto de Desenvolvimento Local. Relatório do que } \\
\text { foi realizado até o momento; sugestões para o folder. }\end{array}$ \\
\hline 9. & $04 / 06$ & Reunião & $\begin{array}{l}\text { Casa de } \\
\text { morador }\end{array}$ & $\begin{array}{l}\text { Conversa com os representantes da Pastoral da Criança sobre a Oficina; } \\
\text { sugestões para o folder. }\end{array}$ \\
\hline 10. & 05/06 & Reunião & PSF & $\begin{array}{l}\text { Conversa com a médica do PSF sobre a Oficina e o sabão escabicida; } \\
\text { idéias para o folder educativo. }\end{array}$ \\
\hline 11. & $08 / 06$ & $\begin{array}{l}\text { Reunião/ } \\
\text { Atividade } \\
\text { educativa }\end{array}$ & EMEIF & $\begin{array}{l}\text { Reunião com as professoras e a coordenadora da escola sobre a oficina; } \\
\text { revisão final do folder; conversa com os alunos sobre sarna e piolho. }\end{array}$ \\
\hline 12. & $10 / 06$ & Oficina & $\begin{array}{l}\text { Casa da } \\
\text { Sopa }\end{array}$ & $\begin{array}{l}1^{\text {a }} \text { Oficina de educação para a Saúde Ambiental: sabão escabicida e } \\
\text { xampu para combater piolhos. }\end{array}$ \\
\hline 13. & $19 / 06$ & Reunião & PSF & Reunião com as agentes de saúde para a aplicação dos questionários. \\
\hline 14. & $06 / 07$ & Reunião & EMEIF & Reunião com as professoras e a coordenadora da escola sobre a oficina. \\
\hline 15. & $06 / 07$ & Reunião & $\begin{array}{l}\text { Casa de } \\
\text { morador }\end{array}$ & Reunião com os representantes da Pastoral da Família no bairro. \\
\hline 16. & $07 / 07$ & Oficina & EMEIF & $\begin{array}{l}2^{\text {a }} \text { Oficina de Educação para a Saúde Ambiental: sabão escabicida e } \\
\text { xampu para combater piolhos. }\end{array}$ \\
\hline 17. & 08/07 & Oficina & $\begin{array}{c}\text { Casa da } \\
\text { Sopa }\end{array}$ & $\begin{array}{l}3^{\text {a }} \text { Oficina de educação para a Saúde Ambiental: pomada cicatrizante e } \\
\text { xarope caseiro. }\end{array}$ \\
\hline
\end{tabular}




\subsection{PRIMEIROS PASSOS PARA O DiÁLOGO: O MUTIRÃo DE LiMPEZA.}

A ação foi idealizada e colocada em prática pelos participantes da Governança Local e seus parceiros, fruto das discussões acerca da problemática ambiental relacionada à destinação do lixo e dos entulhos levantadas pelo Projeto Sócio-Ambiental "Educando Para Renovar”, desenvolvido também pelo Senac e que conta com o apoio financeiro do grupo Santander.

Foram muitas e variadas conversas, com membros dos parceiros envolvidos no Projeto de Desenvolvimento Local - Casa da Sopa Francisco de Assis (CASOFA) - Associação Assistencial e Educacional Espírita, Senac (Serviço Nacional de Aprendizagem Comercial), Associação de Moradores, PSF (Programa Saúde da Família), CRAS (Centro de Referência da Assistência Social), PROAMA (Projeto Amor em Ação), Pastoral da Criança, Equipe de Bethânia (grupo de orações e de assistência a doentes e necessitados - ligado à Igreja Católica), EMEIF (Escola Municipal de Ensino Fundamental) e UNESP.

Foto 6. Centro de Referência da Assistência Social - CRAS - Jd. M. do Sol.

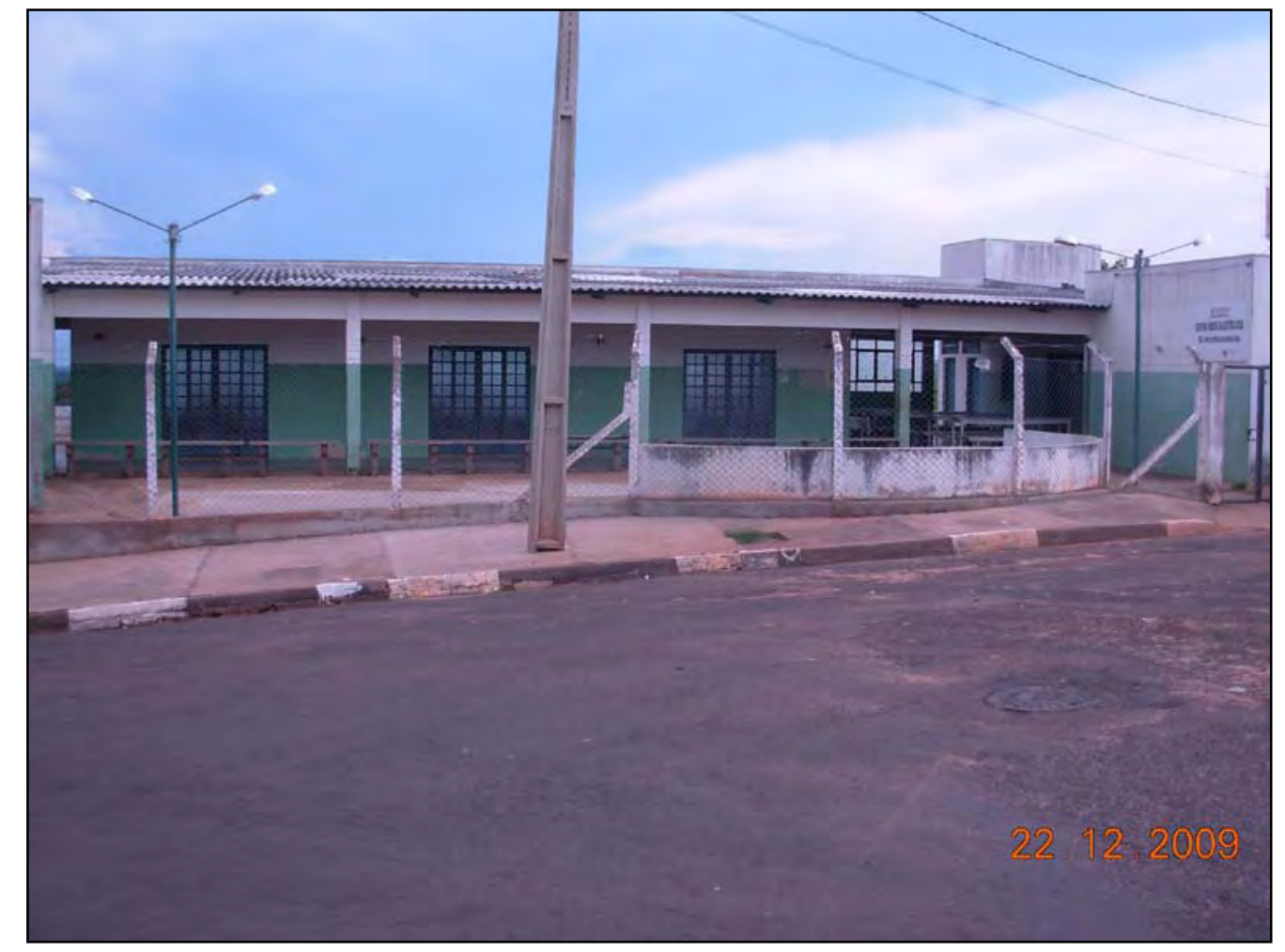

Autora: Torrezan, R. M.

Numa das reuniões de Desenvolvimento Local, foi convidada a coordenadora da Vigilância Sanitária do Município, cuja visão estritamente administrativa instava pela obrigatoriedade da ação sob a forma de Arrastão, ao invés de Mutirão. A discussão girou em 
torno destas duas opções, sendo que, no Mutirão, são as pessoas que colaboram espontaneamente, colocando os entulhos para fora de suas casas; e no Arrastão, os agentes de combate a endemias entram nas casas (embora para isto tenham que contar com o consentimento do morador) e tiram os entulhos.

A questão levantada pela coordenadora da Vigilância Sanitária foi relativa, segundo sua opinião, à falta de conscientização da população local a respeito da importância desta ação, e por isto mesmo defendia a obrigatoriedade garantida pelo Arrastão alertando, contudo, para o fato de ser o Arrastão uma atividade eminentemente anti-popular, apesar de defender esta forma de ação porque, conforme declarou, "Na hora em que se instala a epidemia, como a da dengue,

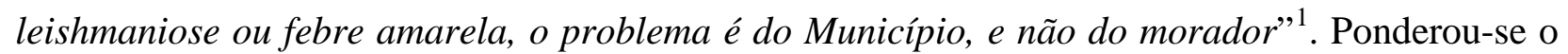
fato de não haver nenhum tipo de epidemia instalada, e da limpeza do bairro constituir uma ação de caráter preventivo. Um outro ponto destacado pela coordenadora dizia respeito aos “conceitos” de entulho e de lixo. Eles não são os mesmos para a população e para os agentes de combate a endemias, uma vez que latas e potes velhos podem ser encarados como objetos de utilidade cotidiana para algumas pessoas, folhas e restos vegetais em decomposição, bem como dejetos de animais espalhados pelo quintal podem ser considerados como adubos, etc.

Por fim, a coordenadora da Vigilância Sanitária comprometeu-se com o fornecimento dos panfletos, de luvas e sacos de lixo.

Foi relatada ainda por moradores do bairro a existência de grande quantidade de animais domésticos soltos pelas ruas, acometidos de doenças como sarna e outras, e infestados por carrapatos e pulgas. Segundo relatos dos moradores, estes cães costumam acompanhar seus donos quando vão à escola, e até mesmo durante o atendimento no PSF. Conforme reclamaram, a Vigilância Epidemiológica não tem atendido às ligações visando o recolhimento de animais abandonados nos bairros.

Considerando os temas levantados, a discussão acabou por revelar a preferência dos participantes pela forma de ação do Mutirão, por sua característica participativa, a ser efetivado no dia 28/03/2009 e através desta opção buscar os melhores meios de sensibilização da população para a limpeza do bairro. No dia anterior, 27/03, as pessoas foram orientadas a colocar os entulhos na calçada, em frente à sua casa, para que os colaboradores voluntários pudessem reunilos nas esquinas de cada rua, facilitando o recolhimento pelo caminhão no dia seguinte.

Na ação do Mutirão pretendeu-se, portanto, assegurar a máxima adesão da população à ação de limpeza. Considerou-se ainda que, uma vez que não estivesse motivada e não entendesse

\footnotetext{
${ }^{1}$ A Coordenadora da Vigilância Sanitária argumenta em sua fala, como se vê, a partir de uma concepção de saúde na escala da população do Município, desconsiderando a problemática em discussão do ponto de vista da vida cotidiana da comunidade e da gestão participativa.
} 
de forma ampla a importância desta ação, a população local poderia promover uma mera "troca de entulhos”, de um quintal para o outro, com as pessoas trazendo para o seu quintal o que o vizinho jogou. Por isto, os participantes da Governança Local acionaram os principais representantes religiosos dos dois bairros, para que o assunto fosse tratado nas reuniões, cultos e missas realizadas na semana anterior ao mutirão. E realizaram um trabalho educativo junto à população, baseado principalmente no "boca a boca” com os moradores.

Embora a abordagem do problema dos entulhos espalhados pelos bairros tivesse envolvido a questão de saúde (relacionada à dengue e à leishmaniose), a realidade é que a motivação primordial da população a respeito do mutirão foi o incômodo causado pela visão do lixo jogado em todo lugar, preocupação na verdade muito mais relacionada ao aspecto estético. Os moradores queriam modificar a idéia de que moravam em bairros “feios” e “sujos”. Esta preocupação está ligada à segregação sócio-espacial a que são submetidos os moradores dos dois bairros.

Portanto, a melhoria na limpeza e a disposição adequada de entulhos (que se acumulam nos terrenos baldios e áreas públicas), e consequentemente a conquista de um bairro mais limpo e bonito foi o objetivo primordial do mutirão. Para isto, acompanhamos as atividades dos participantes da Governança Local, os quais decidiram realizar a ação em três momentos:

- $1^{0}$ momento: capacitação de voluntários para divulgação da ação porta em porta no dia 20/03/2009;

- $2^{\circ}$ momento: divulgação/sensibilização da ação - panfletagem - de 21/03/2009 até o dia 27/03/2009;

- $3^{\circ}$ momento: ação/mutirão - 28/03/2009.

A capacitação reuniu voluntários para a panfletagem, distribuindo a tarefa por ruas a serem visitadas, e orientando sobre a melhor forma de abordar os moradores e salientar a importância da ação para a melhoria do bairro e da qualidade de vida dos moradores. Foram designadas as pessoas responsáveis por buscar a divulgação em rádio e TV, sendo então redigido um texto explicativo sobre a ação, seus objetivos e importância, e sua parceria com o Projeto Sócio-Ambiental do Senac.

No mesmo dia (20/03/2009), integrando as atividades de capacitação, a Vigilância Epidemiológica realizou uma palestra educativa para a comunidade sobre Dengue e Leishmaniose, evidenciando a importância da limpeza dos quintais e áreas verdes públicas para a prevenção destas doenças. Contudo, apesar da participação e interesse da comunidade pelo tema, a palestra não contou com muita abertura para a discussão e o diálogo, razão pela qual várias 
indagações levantadas pelos participantes ficaram sem resposta adequada ou elucidação reflexiva. Na verdade, as perguntas foram simplesmente ignoradas pelas palestrantes.

Como, por exemplo, a questão feita por um morador sobre "o porquê de não existir ainda uma vacina para o combate à dengue, quando se sabe existir tratamento para doenças muito mais recentes e complexas"; e "qual o procedimento a ser tomado pela população no caso de casa e terrenos abandonados, onde são jogados lixo e entulhos”. Um diálogo honesto sobre os direitos dos cidadãos e os deveres das instâncias municipais de vigilância sanitária e epidemiológica, contando com a população e suas sugestões para a resolução dos problemas comuns poderiam ter obtido resultados mais eficazes do que a explanação sobre "flebotomíneos” e “aedes aegypti”. Não que não seja importante informar sobre eles - mas quando a informação se sobrepõe à oportunidade de reflexão, teme-se que o assunto informado e o problema a ele relacionado, além de não serem apreendidos, caiam em terreno estéril por não haver oportunidade de "problematizálos” e, assim, desvelá-los em sua origem.

A busca de patrocínio para a impressão dos panfletos tampouco foi fácil: os vereadores procurados para contribuir exigiam seus nomes nos impressos, em clara intenção de utilizá-los como meio de propaganda política. Em reunião para tratar do assunto, as pessoas participantes manifestaram-se contrárias a qualquer alusão a nomes, em vista de que:

- as cotas de xérox dadas aos vereadores são financiadas com verbas públicas. Pertencem, portanto, à população, e não ao vereador.

- destacar o nome de uma pessoa em particular vai contra a própria proposta da Governança Local, que pressupõe parcerias e ações comunitárias, não sendo baseada em uma única pessoa ou entidade principal.

Apesar dos percalços, um dos vereadores procurados concordou em colaborar, e os panfletos foram xerocados. Eles haviam sido cedidos em pequena quantidade pela Secretaria Municipal de Saúde.

A panfletagem contou com a participação de voluntários constituídos por moradores de várias faixas etárias, membros de comunidades religiosas, adolescentes do Projeto “Ação Jovem”, os quais visitaram uma a uma a totalidade das residências dos bairros.

Desta forma os parceiros da Governança (já incluída a presente pesquisa), juntamente com a Prudenco - (responsável pela limpeza urbana, e que forneceu o caminhão com capacidade para $6 \mathrm{~m}^{3}$ de material em desuso, juntamente com dois funcionários), realizaram esta ação, e contaram com o apoio da Secretaria Municipal de Saúde. 
O Mutirão foi realizado com a participação intensiva da população, sem o que a ação teria sido impossibilitada, já que a Prudenco disponibilizou apenas dois funcionários para a tarefa, sendo um deles o motorista do caminhão.

O efeito do intenso trabalho relativo à conscientização da comunidade acerca da importância da limpeza dos bairros foi positivo: foram retirados doze caminhões de entulho dos dois bairros, o que excedeu em muito às expectativas, e a população correspondeu com uma participação bastante efetiva. Destino dos entulhos foi o lixão da cidade.

A decepção ficou por conta do tratamento dado ao evento pela mídia: o texto elaborado pela Governança Local, em que se enfatizava o trabalho comunitário de reflexão sobre sua realidade e de ação conjunta para a resolução de problemas foi cortado, e a repórter responsável pela matéria tentou induzir a informação de que o foco da ação era a dengue. Gerou revolta entre os membros da comunidade o reconhecimento de que, muitas vezes, os temas veiculados pelas grandes emissoras de TV só entram em pauta se forem pitorescos, gerarem impacto ou estarem atrelados a interesses mercadológicos.

Entretanto, durante as discussões realizadas por ocasião do Mutirão, a disposição final dada ao lixo gerou curiosidade a respeito de sua relação com a existência e a proliferação de moscas domésticas, e a relação destas com a saúde humana. O diálogo a respeito desta temática resultou no colóquio a respeito da pesquisa sobre a proliferação de moscas realizada pelo Laboratório de Geografia da Saúde.

Ao contrário do que realizava o Senac, nas conversas sobre saúde não havia, na verdade, sempre um roteiro pré-determinado rígido ou uma questão/ponto/assunto central sobre a qual se conversaria. Às vezes, até havia um assunto principal (como no caso do questionário e da oficina), mas não era a regra. Essas conversas eram trocas. Trocas de experiências, pontos de vista e percepções, aproximações entre pessoas e entre saberes e experiências. Comentavam-se assuntos do bairro, casos de pessoas necessitadas de auxílio, o problema com o médico do PSF (que não foi aceito pela população por, segundo relatos de moradores, possuir uma postura pedante e distanciada das pessoas), a médica que veio em seu lugar (de quem a população gostou muito, por ser simples, aberta e acessível), casos de infestação por animais peçonhentos (uma moradia do bairro Morada do Sol foi literalmente invadida por uma quantidade imensa de ratos), a preocupação com a coleta seletiva de lixo no bairro (acompanhada de idéias a respeito da montagem de uma cooperativa de catadores), a ausência de iluminação em diversas ruas (e a devida reivindicação de reparos).

Nestas conversas, pudemos obter informações preciosas que nos auxiliaram, posteriormente, na construção do roteiro para o questionário, na seleção das observações a serem 
realizadas, das reuniões paralelas a participar e visitas a fazer. Vínculos foram sendo construídos nesse conversar, gerando afetividade, acolhimento e solidariedade no com-viver.

E aprende-se que, para algo dar certo, é preciso fazer coletivamente, como demonstra a fala de um dos moradores, durante uma reunião: “Algumas ruas estão sem iluminação. Não adiante ligar para a Caiuá, pois é serviço da Prefeitura, eles dizem. Mas os postes estão colocados, falta a ligação e a lâmpada. A gente tem que ir lá na Caiuá junto, porque sozinho, eles não se importam.”

\subsection{O COLÓQUIO: AS MOSCAS EM EVIDÊNCIA.}

O colóquio contou com a participação da bióloga Leonice Seolim Dias, pertencente ao CEMESPP e responsável pela análise biológica das espécies de moscas encontradas nos bairros.

Foram abordados, durante o colóquio, os resultados da pesquisa realizada, demonstrando as principais famílias de moscas encontradas (Muscidae, Calliphoridae, Fannidae e Sarcophagidae), com material impresso (imagens das moscas) para a visualização de seus principais aspectos morfológicos; o seu ciclo de vida (ciclo biológico), picos de ocorrência anual, principais doenças causadas; e ainda as formas de controle mais eficazes.

Em sua luta para a conquista de direitos sociais que eles sabem ser seus, os moradores manifestaram o desejo de aprofundar os conhecimentos acerca da pesquisa com as moscas, e buscar soluções para os problemas levantados. Foi relatada pelos moradores presentes ao colóquio a infestação dos bairros por moscas nos anos de 1996/1997, quando verdadeiros enxames de moscas invadiram a área dos dois bairros, provocando grande transtorno à população. Após investigação, descobriu-se que uma propriedade rural adjacente comprava adubo orgânico proveniente de granjas da região, deixando-o a céu aberto, ocasionando a proliferação exagerada das moscas.

Os participantes, que inicialmente declararam não fazer idéia do perigo à saúde representado pelas moscas, mostraram-se preocupados e dispostos a pensar nas possíveis soluções para o problema. Embora a saúde não estivesse, ainda, entre as prioridades iniciais levantadas na Agenda de Prioridades, o trabalho sobre as moscas e a pesquisa desenvolvida conjuntamente à comunidade acabou por inserir as questões relacionadas à saúde definitivamente nas discussões correntes entre os moradores e os representantes das várias instituições e entidades públicas atuantes no bairro. 


\section{FoTo 7. O Colóquio - Casa da Sopa.}

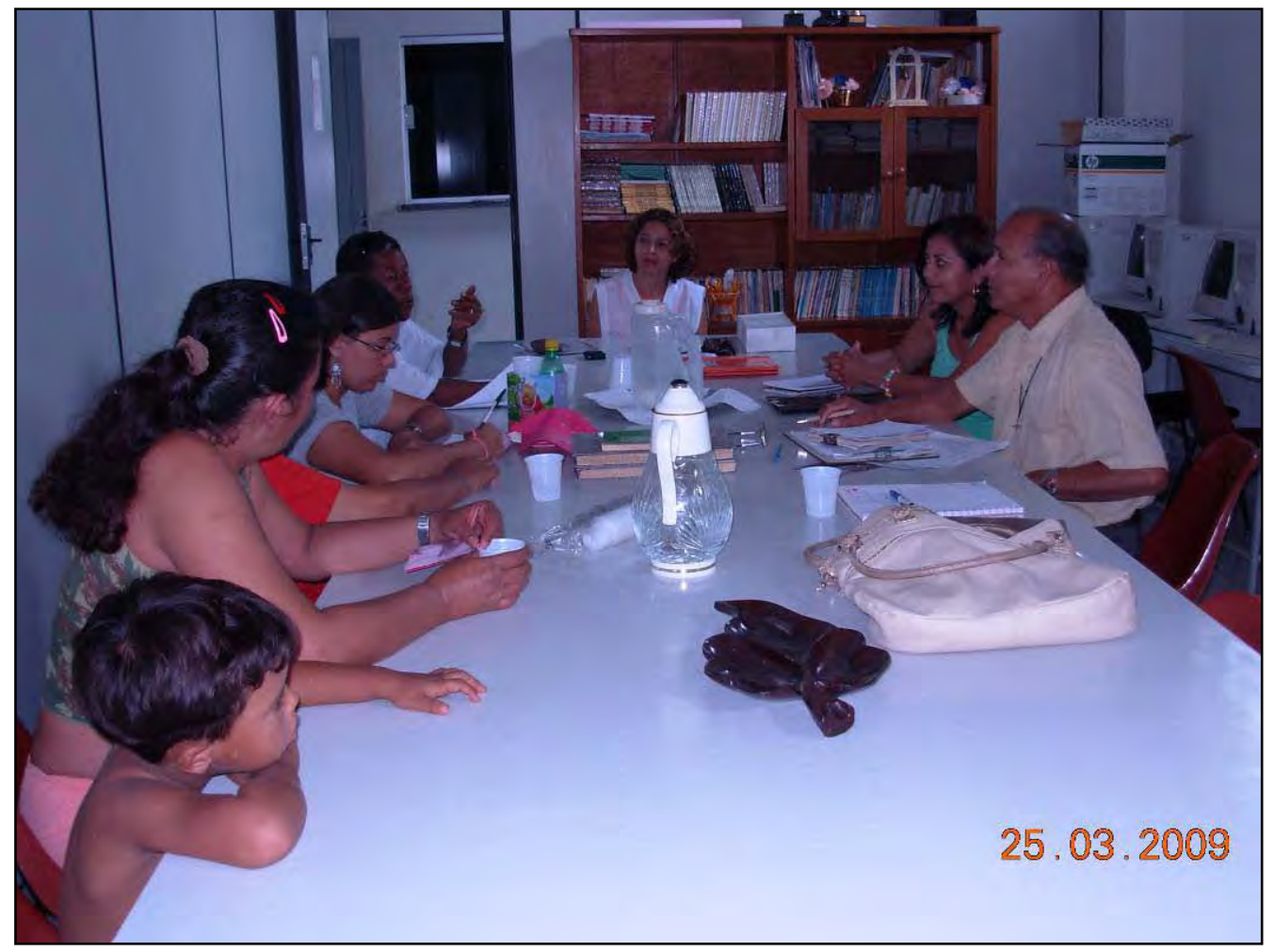

Autora: Torrezan, R. M.

O resultado deste colóquio foi a sugestão de uma Ação Preventiva, através da elaboração de uma proposta educativa em saúde junto à comunidade, visando abarcar problemas de saúde normalmente negligenciados pelos profissionais e órgãos de saúde pública, tais como as doenças veiculadas pelas moscas. Configuraram as idéias do grupo:

1. Realizar um trabalho de Educação em Saúde, buscando a parceria da Pastoral da Criança, dos Agentes de Saúde do PSF (Programa Saúde da Família) local e da EMEIF localizada no bairro, além de outros parceiros que compõem a Governança Local;

2. Elaborar folhetos educativos a respeito das moscas e das doenças que elas podem transmitir;

3. Elaborar um questionário com o objetivo de investigar a respeito da saúde e do ambiente, visando futuras ações educativas junto à população local.

Ressalta-se a relevância levantada pela comunidade, da implantação de um programa de controle de moscas, que integre a questão entomológica às questões constituintes da saúdeambiental, através da ação educativa, e ainda a promoção do diálogo entre os representantes dos diferentes setores da gestão pública e da sociedade local.

Para as estratégias de Educação em Saúde foram realizadas reuniões durante as quais se discutiu qual a melhor forma de abordar assuntos delicados relacionados à manutenção da saúde, 
assuntos que muitas vezes se inserem na vida particular das pessoas, em suas crenças e modos de vida. Buscou-se também, através das discussões, a melhor forma de se obter dados sobre saúde que não constavam no PSF, a respeito de doenças que poderiam ser veiculadas pelas moscas, como as doenças de pele, parasitoses, míiases, e outras. Embora os dados sobre diarréias e conjuntivite existissem no PSF, decidiu-se pela elaboração do um questionário concomitantemente às ações educativas iniciais, com a finalidade de se obterem resultados mais recentes (os dados do PSF eram referentes ao período 2006-2007) sobre a saúde ambiental nos bairros.

\subsection{O QUESTIONÁRIO: UMA CONSTRUÇÃO COLETIVA.}

O questionário (Anexo 1) foi elaborado através de diversas reuniões com membros da comunidade e seus representantes, tendo sido todas as questões baseadas nas discussões realizadas durante as reuniões de Desenvolvimento Local sobre os principais problemas ambientais e de saúde que afligem a população local.

Deve-se levar em consideração um aspecto importante da escolha pela metodologia da pesquisa-ação, do trabalho com comunidades e da educação popular: o tempo em que as tarefas conjuntas são efetivadas não é o mesmo do tempo que levam se forem realizadas individualmente pelo pesquisador. Para um pesquisador, elaborar um questionário sobre o que ele tenciona saber sobre o seu objeto de estudo não leva mais do que poucos dias. Mas quando se trata de um trabalho coletivo, de interesse também coletivo, o caminho é outro: mais longo, mais complicado, mas com resultados mais fiéis e gratificantes. A discussão coletiva para se chegar a um consenso razoável de idéias não é um acontecimento idílico, pontuado por situações de pleno acordo que acontecem num minuto. A descrição pode fazer parecer assim, mas não é. Como já foi dito, a palavra escrita limita muitas vezes a apreensão dos impasses, discordâncias e conflitos acerca do que se discute. Mesmo assim, nada é resolvido com votação - discute-se para se chegar a um consenso. Tanto melhor, pois quando algo necessita de votação é porque ainda há muita divergência: então precisa ser mais discutido e pensado conjuntamente (FREIRE, 1980)

Foi durante um mês e meio de discussões a respeito de diversos assuntos que se deu a elaboração do questionário, somando um total de seis reuniões em que ele foi debatido. Na primeira reunião, foram levantados os temas sobre ambiente e saúde que a comunidade achava importante investigar: água/esgoto; lixo (destinação, armazenamento); infestação da residência por animais peçonhentos (assunto alvo de reclamações constantes durante as reuniões); terrenos vazios onde são depositados animais mortos; alagamentos de ruas onde o asfalto encontra-se danificado, ocasionando poças passíveis da proliferação de larvas de moscas e mosquitos; 
doenças que podem ser transmitidas por moscas e outras de fácil proliferação, como sarna e piolho.

Surgiram, então, as preocupações relativas aos cachorros abandonados nas ruas, à criação de animais por pessoas do bairro e a falta de preocupação destas com a higiene dos locais onde estes animais vivem. Casos de locais imundos, mau cheiro de dejetos não que não são limpos incomodando a vizinhança e carcaças de animais mortos jogados em terrenos vazios haviam sido relatados em diversas reuniões anteriores.

Também surgiram indagações a respeito dos hábitos de higiene pessoal da população do bairro, uma vez que as professoras da EMEIF observaram que muitas crianças não tomam banho, nem usam roupas limpas, sendo por isso alvo de chacotas e de preconceito por parte dos colegas, e também possuindo doenças de pele. Mas as questões sobre higiene foram muito difíceis de elaborar: os integrantes da Governança consideravam delicada a questão da higiene, por seu caráter extremamente pessoal. As questões relativas a higiene pessoal foram restringidas ao mínimo necessário devido a este desconforto com relação ao tema, cuja discussão para melhorar a abordagem dele junto à comunidade ainda está para acontecer.

Após a $1^{\mathrm{a}}$ revisão do questionário, surgiram ainda as idéias de investigar o grau de escolaridade das pessoas de cada família, e de saber qual das entidades e instituições mais eram utilizadas pela população. Um outro ponto acrescentado diz respeito às duas únicas questões abertas do questionário, nas quais o entrevistado é chamado a emitir sua opinião pessoal de forma livre: a comunidade julgou importante saber qual a opinião das pessoas sobre o que aflige sua saúde, e quais as melhores soluções sugeridas. As respostas poderão apontar aos próximos passos para a resolução dos problemas.

Havia a preocupação fundamental da identificação correta do membro da família a responder às perguntas, e de garantir sua adesão voluntária à importância de colaborar. Por isto o termo de consentimento a ser assinado pelo morador também foi acrescentado.

Nesse sentido, a formulação coletiva do questionário necessitou da incorporação de uma série de discussões já realizadas acerca dos problemas ambientais e de saúde vivenciados pelos moradores do bairro, além de uma série de novas discussões que precisaram acontecer. Segundo BRANDÃO (2006), a necessidade de discutir para aprofundar certos temas e reforçar as reivindicações populares deve ser transformada em exigência metodológica: as questões levantadas em grupo devem compor um "roteiro de discussão" sobre o problema "saúde”, para se efetivar o trabalho de investigação coletiva.

O roteiro das discussões utilizado para a elaboração do questionário foi o seguinte: 


\section{Apresentação (identificação do morador).}

o Idade.

o Número de pessoas que moram na casa.

o Escolaridade de cada membro.

2. Introdução (investigar o que o entrevistado sabe sobre o assunto, e sua opinião).

o O que sabe sobre sua saúde e o que a afeta.

o O que pode ser feio no bairro para melhorar a saúde dos moradores.

\section{Relação ambiente/saúde (baseada nas discussões realizadas nas reuniões).}

o Água (proveniência)

o Caixa d’água (limpeza, armazenamento).

o Saneamento (tipo, disposição do esgoto).

o Lixo (destinação, separação, armazenamento).

o Localização da moradia (terrenos baldios, com lixo, infestação por animais peçonhentos).

o Drenagem (alagamentos, formação de poças fundas).

\section{Relação higiene/saúde.}

o Animais (criação, limpeza e manutenção dos locais de criação, quantidade, espécies, vacinação, castração).

o Alimentos (conservação, armazenamento, manuseio).

o Higiene pessoal e da casa (banho, asseio).

\section{Doenças.}

o Doenças de pele (miíases, bicheiras)

o Diarréia.

o Conjuntivite.

o Viroses.

Revisado uma segunda vez, as questões que ainda estavam com as alternativas incompletas foram melhoradas, e a questão sobre a limpeza dos locais onde se criam animais também acabou por ser modificada, optando-se por incluí-la na forma aberta. Após os ajustes necessários, foi realizada a revisão final. Com a aprovação definitiva da comunidade, o questionário foi encaminhado para impressão.

\subsection{A BUSCA do DiÁlogo NA TENTATIVA DE DERRUbAR AS BARREIRAS ENTRE O PSF, A} COMUNIDADE E A ESCOLA.

Quanto à aplicação do questionário, decidiu-se ser uma tarefa deixada a cargo dos agentes de saúde do PSF, uma vez que a comunidade considerou ser esta uma boa oportunidade de otimizar a interação entre os agentes e os moradores. 
FoTo 8. Programa Saúde da Família - PSF - Jd. M. do Sol

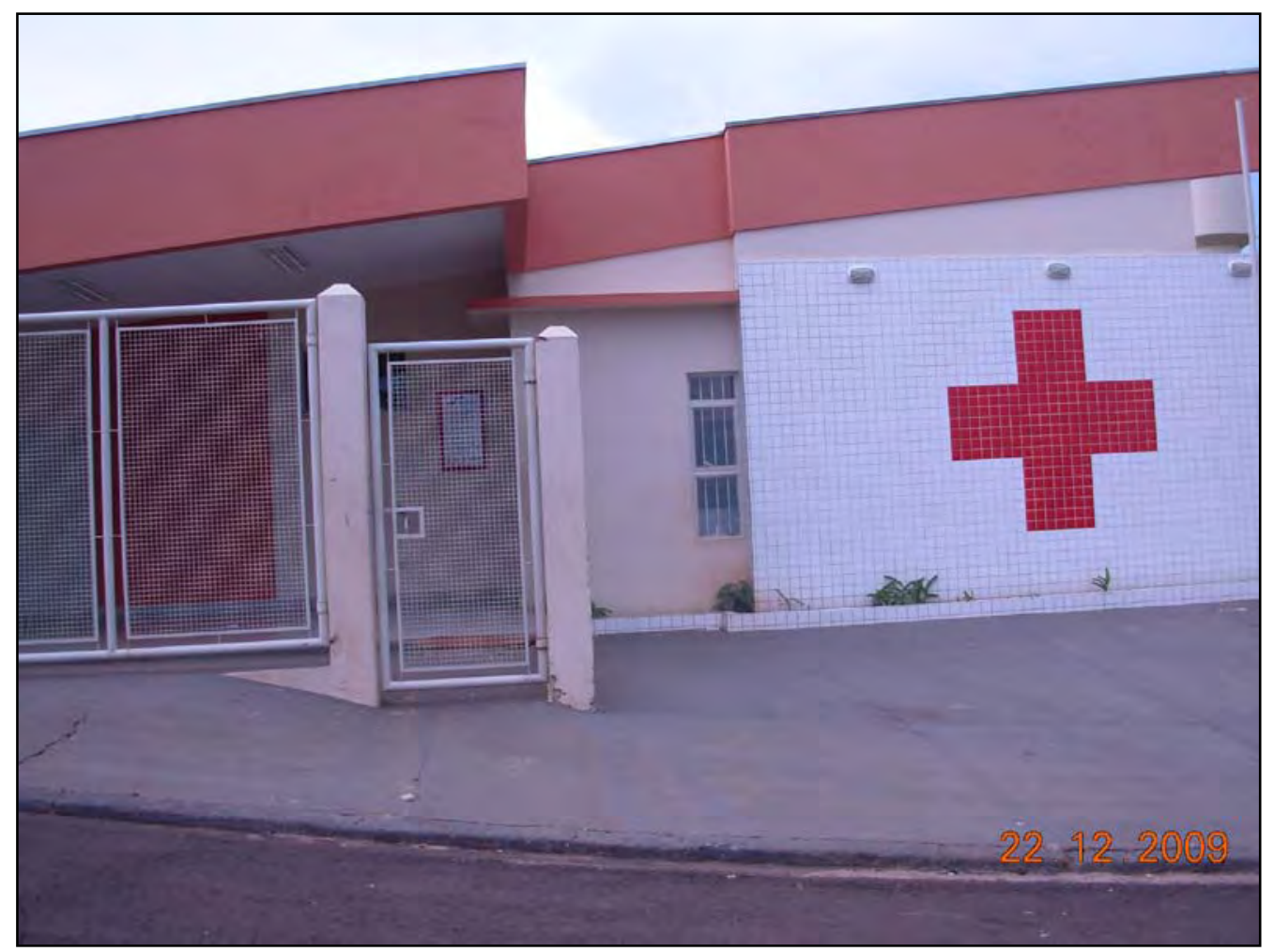

Autora: Torrezan, R. M.

Em algumas reuniões havia sido comentada a pouca afinidade entre os moradores e os agentes do PSF. Buscava-se uma maneira de "quebrar o gelo" e, com isto, alcançar a otimização do trabalho destes profissionais junto à comunidade. Os questionários configuram um dos caminhos apontados nesta direção, pois abrem um espaço para o diálogo mais do que necessário entre os agentes e as pessoas com as quais devem se relacionar diariamente.

Aliás, parece inconcebível não existir interação entre agentes de saúde do PSF e as pessoas com quem eles irão lidar, pessoa de quem eles deverão “cuidar”, no sentido mais estrito do termo, pois o cuidado com a saúde envolve todos os aspectos da vida da pessoa. Isto é grave, no sentido de que normalmente o que ocorre é o contrário, mesmo que de acordo uma ideologia dominante organizada para levar seus valores a comunidades periféricas através dos serviços de saúde. Conforme vemos em Albuquerque, (2003, p. 45):

É sabido que a saúde pública intervém diretamente nas relações sociais tanto intradomiciliares como na comunidade, quando difunde idéias, valores, normas sanitárias a serem seguidas para o controle de doenças, estabelecendo o modo de fazer e agir da classe dominante como modelo para as classes populares, num mecanismo ideológico de mitificação da primeira e desvalorização das últimas. 
A realidade da atenção básica na periferia e na zona rural é que a referência ao saber, e ao poder médico e técnico é marcante, perpassando por isso os agentes de saúde. Isto se traduz em uma influência significativa da equipe de saúde sobre as relações sociais da comunidade. Com o PSF, os agentes de saúde assumem características mais profissionais do que de participação comunitária, e com isso reduzem ações referentes ao âmbito do saber popular, transferindo-as para a equipe de saúde. Tanto é que problemas corriqueiros de saúde que eram solucionados com chás e rezas passam a ser medicalizados; atitudes diferentes são incorporadas à cultura local, e passam até mesmo a constituir regra, introduzem-se novos hábitos, e inclusive os objetos comprados nas mercearias mudam: escovas de dentes, pastas, filtros, camisinhas, adoçantes, suplementos alimentares, novos medicamentos. Normalmente, os médicos e enfermeiros tornam-se referência nas comunidades, são procurados para conselhos familiares e para desabafos pessoais. São protegidos pelas “gangs” locais e agradados. Na verdade, há uma orientação para que os membros das equipes interajam com a comunidade local, suas entidades e órgãos representativos, como associações de moradores e movimentos de igrejas de todos os credos, incluindo diretores de escolas e coordenadores de grupos musicais e culturais. O problema é que os profissionais de saúde geralmente são capacitados para tratar doentes no ambiente hospitalar. Na comunidade é diferente, e sem orientação específica sobre a melhor forma de desenvolver relações com a população (como mobilizar para atividades comunitárias), o que acontece é o uso do senso comum: a troca de artifícios para a obtenção de apoio e participação, o uso da autoridade do saber técnico e a desvalorização do saber popular (ALBUQUERQUE, 2003).

No entanto, pior do que uma equipe de PSF que interage com a comunidade de acordo com suas concepções de classe dominante, é uma equipe de PSF que não interage com a comunidade de maneira nenhuma: existia uma barreira entre os profissionais do PSF e a comunidade do Morada do Sol e do Belo Galindo, e ela precisava ser derrubada, cedendo espaço ao diálogo e à cooperação. Mas todos concordávamos que este intento não podia ser conseguido através de exigências, ou reivindicações. Isto somente faria aumentar o a tensão existente e ampliar o fosso formado entre as pessoas e estes profissionais, o que não seria nada bom para os propósitos de todos os envolvidos. A estratégia, de acordo com decisão da comunidade, deveria partir do diálogo.

Na reunião em que conversamos com a enfermeira-chefe do PSF, ficou clara a sua decisão de colaborar. Mas o que nos preocupava era saber se os agentes iriam colaborar: caso se mostrassem resistentes, haveria um sério impasse. 
Em reunião posterior, descobrimos tratarem-se das agentes: só havia mulheres. Reticentes no início, acabaram por se renderem à insistência dos membros da Governança Local sobre a importância do questionário para a comunidade como um todo. No fim, as agentes de saúde concordaram que a aplicação do questionário seria uma colaboração essencial ao seu trabalho e às ações da comunidade. Mostraram-se receptivas, e dispostas às perspectivas de diálogo com a Governança Local e a comunidade.

O PSF do Jardim Morada do Sol, e que atende também ao bairro adjacente, Residencial Francisco Belo Galindo, conta com cinco agentes, sendo que no momento havia uma de férias. Elas têm a função de percorrer todas as residências de famílias cadastradas no PSF (sendo um total de 780 famílias) durante o mês. O que significa uma média de 195 visitas a serem efetivadas pela equipe por semana. Evidentemente, consideramos que, com esta tarefa (a aplicação dos questionários) sendo acrescentada às visitas, haveria a necessidade de mais tempo para que fosse alcançado o total das residências pesquisadas. Por conta disto, e do número elevado de residências a serem visitadas, a aplicação dos questionários duraria cerca de um mês e meio.

Após a reunião com as agentes de saúde, a animação tomou conta dos participantes. Julgava-se que não haveria receptividade por parte delas, e foi exatamente o contrário. O que tinha faltado mesmo, até aquele momento, era uma boa conversa, franca e honesta. Com o resultado positivo obtido, uma "reunião relâmpago" foi proposta: que tal se todos fôssemos até a escola, entabular um diálogo com a diretora também? Desde o início dos trabalhos da Governança Local, convites insistentes haviam sido feitos para que a diretora da escola comparecesse e participasse, e trouxesse os outros profissionais da EMEIF para contribuir com suas idéias, mas até aquele momento, ninguém jamais havia aparecido ou dado uma satisfação. A indiferença por parte da diretora e dos professores intrigava a todos. Imbuídos do sensato saber popular baseado no antigo ditado “Se Maomé não vai à montanha, a montanha vai até Maomé”, decidimos, pois, estabelecer contato direto com a escola, e solicitamos uma reunião imediata.

A diretora nos recebeu gentilmente. Estávamos em pequeno número, somente sete, pois por se tratar de reunião paralela, dava-se em horário em que outros participantes estavam trabalhando. Explicamos o trabalho da Governança Local junto à comunidade, e refizemos o convite já tantas vezes reiterado. Relatando as dificuldades pelas quais passa a escola, entendemos o porquê da ausência nas reuniões: não há professores substitutos, e nem vice-diretor na escola. Isto significa que, qualquer ausência de profissionais deixa a escola desfalcada, e isto não pode ocorrer, sob penalidade administrativa a ser sofrida pelos profissionais. 


\section{Foto 9. Escola Municipal de Ensino Fundamental - EMEIF - Jd. M. do Sol.}

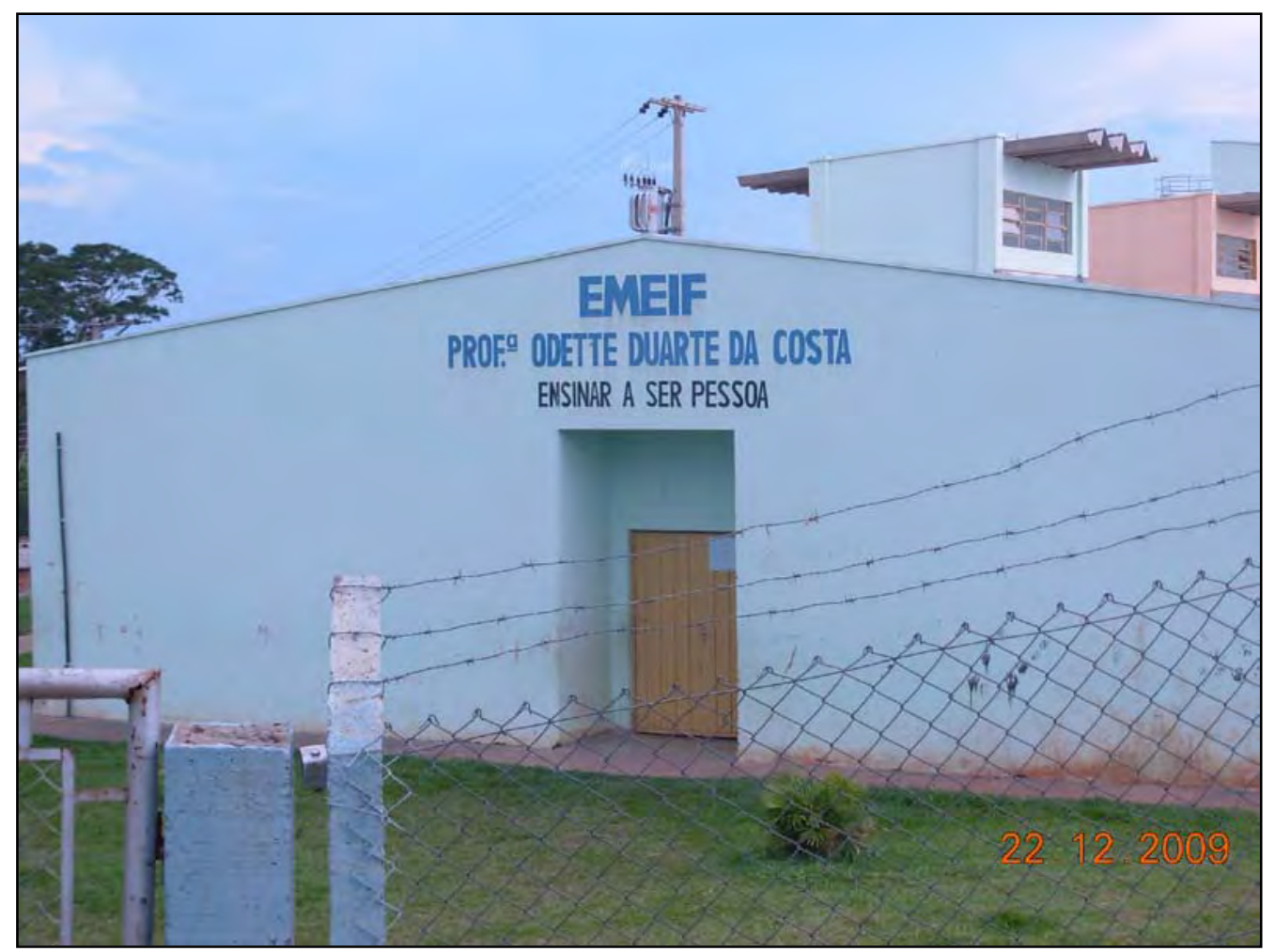

Autora: Torrezan, R. M.

Sendo assim, conversamos em busca de uma alternativa. A melhor maneira encontrada seria a dispensa de algumas professoras dos HTPC’s, que são os horários de trabalho pedagógicos coletivos delas, para que participassem das reuniões de Desenvolvimento Local. Mas somente um número reduzido de professoras poderia participar, pois uma boa parte delas dá aulas em outras escolas da cidade, em outro período, e por isto não podem comparecer.

A busca desta participação revelou a rotina de trabalho extenuante dos profissionais da educação. Não há como sair nem por alguns minutos da sala de aula, pois não há quem olhe as crianças neste meio tempo; as professoras, diretora e coordenadora trabalham normalmente três períodos para garantir condições dignas de sobrevivência, acumulando cargos e funções, dificultando sua interação com as comunidades nas quais trabalham (interação esta que constitui um requisito fundamental para a qualidade do trabalho educativo e para a superação de problemas); e há ainda a exigência do cumprimento de uma série de projetos e programas da Secretaria Municipal de Educação a serem implementados, projetos e programas que muitas vezes pouco ou nada tem a ver com os problemas vivenciados na escola do bairro.

Um outro aspecto, ainda, nos foi revelado: mesmo trabalhando o dia todo no bairro, quando um dos profissionais da escola passa mal, não é atendido pelo PSF, que fica localizado do 
lado oposto ao da EMEIF, cerca de 50 metros rua acima . O PSF só pode atender moradores do bairro. Os que trabalham nele ficam de fora. Este fato demonstra uma falha crucial na concepção do serviço prestado pelo PSF, pois não leva em consideração o fato de alguns profissionais ficarem mais tempo no bairro do que alguns moradores (cujos serviços estão fora do bairro e os obriga a passarem 12 horas ou mais em outros locais, vindo às suas casas praticamente apenas para dormir).

FOTO 10. O PSF visto da frente do portão da EMEIF - Jd. M. do Sol.

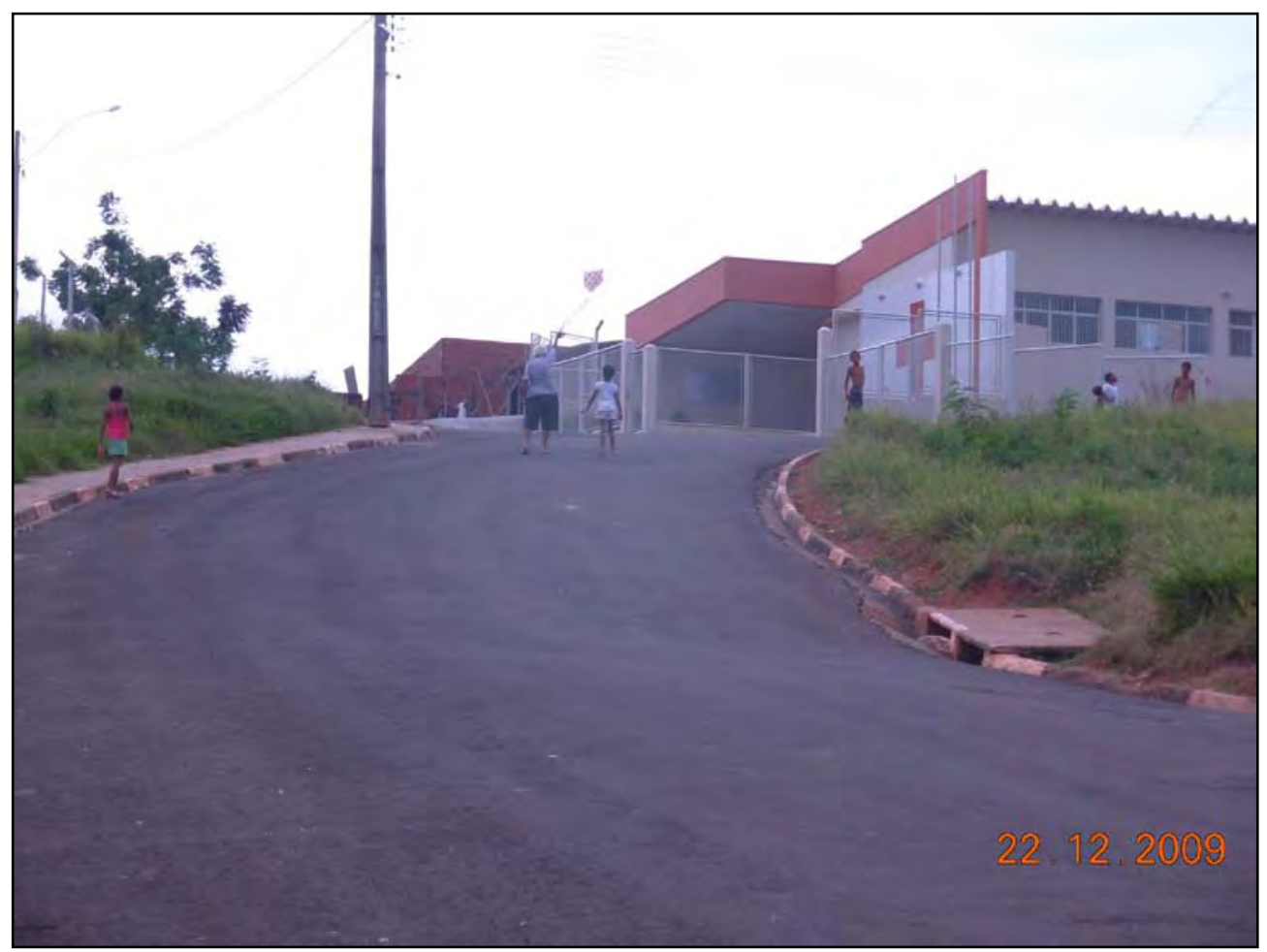

Autora: Torrezan, R. M.

O que também leva à outra reivindicação há muito almejada pelos moradores: a de uma Unidade Básica de Saúde (UBS). Isto porque o PSF também não atende emergências, encaminhando os doentes para outros postos de saúde dos bairros adjacentes. Normalmente lotados, estes pacientes são então encaminhados ao Hospital Universitário (HU), também invariavelmente superlotado. A maioria dos casos compreende problemas de saúde facilmente resolvidos em uma UBS. Por outro lado, a demora dos trâmites no processo de encaminhamento para as UBS's adjacentes, e depois para o HU, e mais a espera pelo atendimento neste hospital, faz com que muitos pacientes de urgência tenham seus problemas seriamente agravados.

Os passos dados em direção à EMEIF e ao PSF, e aos seus profissionais, foram dados pelos membros da comunidade, e ainda estão no início. Foram os primeiros passo em direção do diálogo e da ação conjunta. Muito longa é ainda a caminhada a ser empreendida nesta direção, mas consideramos que uma longa caminhada começa mesmo a partir do primeiro passo. 
A insegurança geral a respeito do trabalho do PSF no bairro parecia desfeita. As reuniões nas quais participou a enfermeira-chefe e, posteriormente, o comparecimento de duas das agentes em uma Oficina parecia selar a parceria tão almejada.

Mas não foi o que aconteceu.

Um mês após a conversa com as agentes, e sem notícia a respeito do andamento das visitas domiciliares, a Governança Local comprovou as antigas desconfianças dos moradores do bairro: apenas dois questionários haviam sido aplicados, sendo que somente um deles por completo.

Inquiridas sobre os motivos da sua não-aplicação, as agentes responderam simplesmente que não era possível aplicá-lo, por ser, segundo elas, muito longo e tomar muito tempo das visitas. Em vista disto, foi proposta a alternativa de aplicá-lo em duas ou mais etapas, já que o questionário divide-se em módulos perfeitamente passíveis de serem separados. Embora demorasse mais tempo, era uma alternativa viável. As agentes, contudo, recusaram-se terminantemente a fazê-lo, alegando que a aplicação lhes trazia problemas com suas tarefas ordinárias, atrasando-as. Segundo afirmaram, não entendiam o interesse da comunidade por este assunto, e argumentaram que a própria comunidade deveria aplicar os questionários, já que o elaborou.

\subsection{A SARNA, O PIOLHO E A AÇÃo EDUCATIVA.}

A Governança local, contudo, considerou que, no meio tempo em que o questionário estava sendo elaborado e depois aplicado, poder-se-ia realizar uma pesquisa informal, baseada no boca-a-boca com amigos, vizinhos e participantes de atividades religiosas sobre a saúde da população, e a partir disto dar início às ações educativas.

Embora focalizando sobretudo os agravos à saúde relacionados às moscas vetoras de doenças, esta pesquisa prévia acabou por descobrir outras doenças que agravam os problemas por elas causados, e revelou-se, portanto, a necessidade de combatê-los.

Através da participação das professoras da EMEIF (Escola Municipal de Ensino Fundamental), que iniciaram o convívio com a Governança Local nas reuniões; das conversas pelo bairro e da observação atenta realizada por moradores, foi constatado que os problemas de saúde mais prementes no bairro são aqueles que atingem principalmente as crianças em idade escolar: a sarna (que infesta também seus cães de estimação), o piolho, as "bicheiras”, a tosse e a bronquite. Segundo relato das professoras e da diretora da escola, estes problemas de saúde interferem bastante no aproveitamento escolar dos alunos. 
Decidiu-se então, primeiramente, pela realização de 4 ações educativas de combate aos problemas de saúde apontados:

1. Teorização com os representantes comunitários.

2. Oficinas a serem realizadas com os pais e membros da comunidade.

3. Trabalho conjunto com as professoras da EMEIF e com as crianças.

4. Reunião com os agentes de saúde, para o devido acompanhamento dos casos mais graves.

A Oficina foi uma das formas mais adequadas de abordagem apontada pelo grupo, uma vez que é uma maneira de “ensinar fazendo” (Quadro 5), proporcionando maior interação com o conteúdo abordado,e por isto resultando em maior aproveitamento. Na Oficina, vários sentidos são estimulados, proporcionando maior interação entre os participantes.

Na Oficina tem-se a interação entre diversos sentidos que, juntos, perfazem o caminho útil ao aprendizado coletivo e à integração entre os membros da comunidade: as mãos realizam trabalho; a voz narra fatos, histórias, informações, impressões; os ouvidos escutam estas narrativas; e a alma registra e relaciona memórias. Tudo isto constrói uma oportunidade privilegiada de convivência comunitária, abrindo caminhos e conquistando espaços únicos de participação e diálogo. É a união entre os saberes e fazeres dos sujeitos envolvidos na luta pelo direito social à saúde, uma luta que vai além da "doença e não é apenas uma luta contra os maus serviços de cura da doença” (Equipe das Comunidades, 1988, p. 193, in STOTZ, 2005).

QUADRO 5. Oficina - interação entre sujeitos, saberes e fazeres.

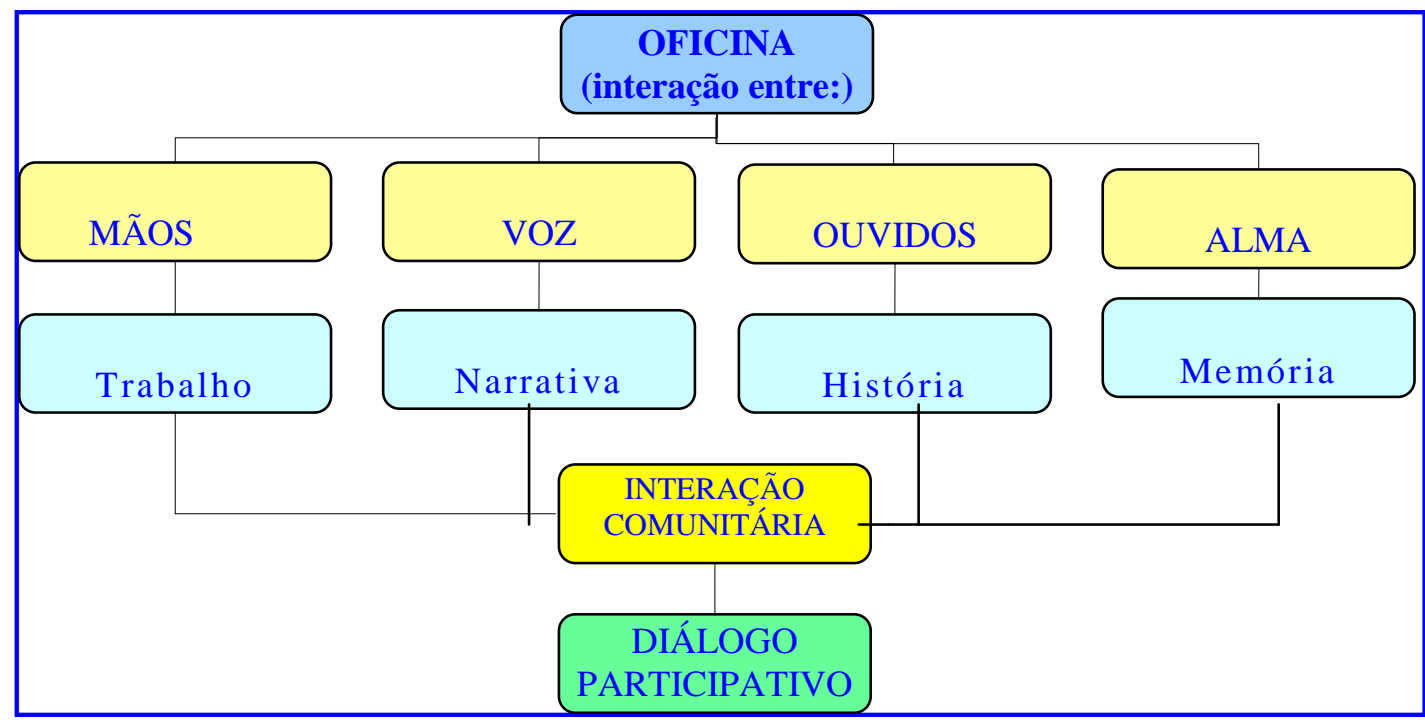

Org.: Torrezan, R M (2008) 
A Oficina , na verdade, é uma opção política de saúde, ao levar ervas e palavras realiza sua função, transformando o processo de curar-se num processo crítico e conscientizador. Através da palavra inicia-se, segundo FREIRE, o processo de "estar sendo no mundo", estar consciente de sua humanidade.

Outras sugestões foram incorporadas: trabalhar em conjunto com a Pastoral da Criança; não ficar, segundo uma moradora "encumpridando conversa, que o povo não gosta muito" - ser claro; “chegar na mulher, porque ela participa mais, luta mais, aparece mais” (note-se que esta foi uma observação realizada por um homem).

Através de uma reunião, socializaram-se informações com os participantes; observou-se o nível de conhecimento que eles tinham acerca da escabiose e da pediculose, quais as noções apresentavam sobre essas ectoparasitoses. Nessa reunião foi elaborado também o folder ilustrativo, onde se encontravam informações básicas sobre como combater as doenças, a partir do qual seria desenvolvida uma exposição dialogada junto à comunidade durante a Oficina sobre a escabiose e pediculose, além de noções básicas sobre a relação ambiente, higiene e saúde.

\section{A 1 ${ }^{\text {a }}$ OFICINA: EDUCAÇÃO PARA A SAÚDE AMBIENTAL.}

A $1^{\text {a }}$ Oficina foi realizada pelos participantes da Governança Local e seus parceiros: Casa da Sopa (ONG Casa da Sopa Francisco de Assjs - CASOFA - Associação Assistencial e Educacional Espírita), Senac (Serviço Nacional de Aprendizagem Comercial), Associação de Moradores, PSF (Programa Saúde da Família), CRAS (Centro de Referência da Assistência Social), PROAMA (Projeto Amor em Ação), Pastoral da Criança, Equipe de Bethânia (grupo de apoio social ligado à Igreja Católica), EMEIF (Escola Municipal de Ensino Fundamental) e Unesp. Nesta Oficina, um membro da comunidade ensinou como fazer um sabão caseiro escabicida para cães e também como adequar a receita para possibilitar o uso humano, e ainda um xampu caseiro com erva para o combate ao piolho. As receitas de sabão e do xampu foram disponibilizadas à população dos dois bairros através de um folder com informações sobre higiene e saúde.

Para a realização desta oficina dividiram-se tarefas: a Casa da Sopa contribuiu com o fornecimento do local, fogão, botijão de gás e utensílios; a pesquisadora com as ervas, o enxofre em pó, o xampu, os recipientes para armazená-lo e a soda líquida; o Senac com o amaciante e a disponibilização do folder para a população do bairro e a comunidade com o óleo reaproveitado.

Através de uma metodologia problematizadora realizou-se uma oficina pedagógica dividida em três momentos: 
- diálogo inteligente, que se constituiu de um bate-papo com a comunidade para verificação do seu conhecimento prévio sobre ambiente, higiene e saúde, e sua co-relação com a escabiose e a pediculose: em clima leve e agradável, a oficina foi iniciada com uma exposição dialogada com os participantes, que compareceram em número razoável em se tratando de um dia de semana, à tarde, período em que normalmente as pessoas estão trabalhando.

- teorização, representada pela explicação dos aspectos mais relevantes do contágio dessas doenças e esclarecimento de dúvidas: momento bem curto e objetivo, para não cansar os participantes;

- fazendo o sabão e o xampu, momento em que foram empregados os conhecimentos de um membro do grupo de apoio social Equipe de Bethânia e representante da comunidade para o sabão; e os conhecimentos referentes às ervas disponibilizados gentilmente por membros da Pastoral da Saúde, que permitiram fazer o xampu para o combate aos piolhos. O referido membro da comunidade começou a fazer o sabão, ao mesmo tempo em que conversava com as pessoas sobre as propriedades do sabão, a forma de utilizá-lo, noções básicas de higiene, e como adequar a fórmula para uso humano.

FOTO 11. Fazendo o sabão - Oficina do sabão e do xampu - Casa da Sopa.

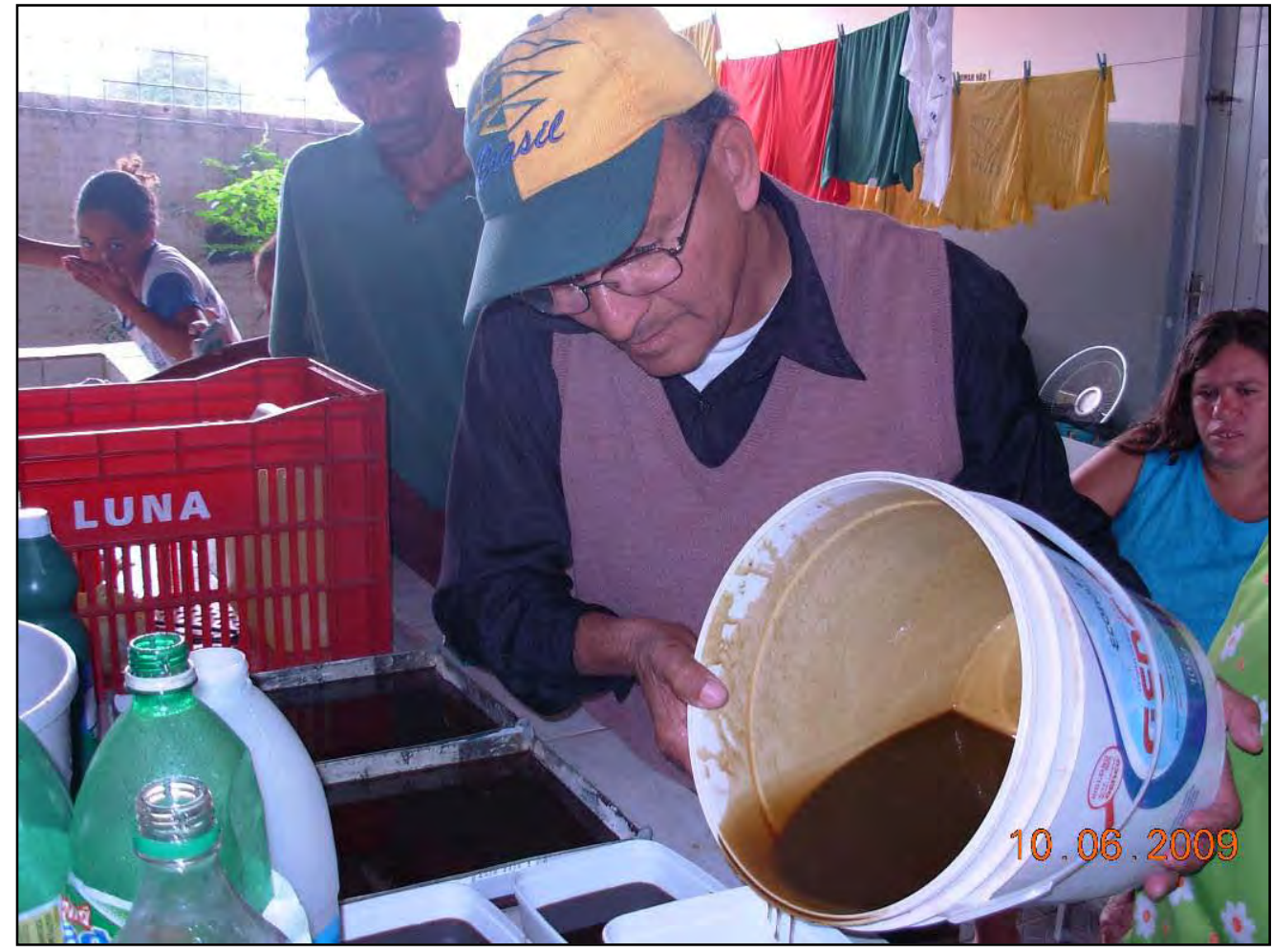

Autora: Torrezan, R. M.

Enquanto a mistura era mexida, membros da comunidade e da Casa da Sopa auxiliaram na mistura que comporia o xampu. O diálogo permeando sempre as ações, os comentários, as 
ofertas de auxílio para misturar, mexer, diluir... A expectativa sobre o resultado: será que o sabão vai adquirir consistência? E o xampu, não vai ficar com um cheiro muito forte?; - a valeriana utilizada no xampu possui um odor forte e desagradável. No final, o resultado agradou a todos: o sabão adquiriu a consistência exata, e o xampu acabou com aspecto e cheiro agradável, e cada qual levou para casa um pouco do sabão e do xampu para testar.

No final, foram distribuídos os folders (Anexos 2 e 3) com as receitas do sabão e do xampu, e um folheto sobre a valeriana utilizada para fazer o xampu, posteriormente disponibilizados à toda a comunidade.

A elaboração do folder contou com as sugestões e idéias dos participantes da Governança Local, das professoras, da médica do PSF, enfim, de várias pessoas da comunidade e pessoas que trabalham no bairro em contato direto com a população e conhece seus problemas. A idéia inicial do folder era contar com a produção de textos e desenhos realizados pelas crianças, as quais realizaram diversas atividades relacionadas ao meio ambiente e saúde do Projeto Sócio-Ambiental "Educando para Renovar" do Senac, mas os arquivos não foram organizados em tempo. Mesmo assim, o Senac disponibilizou as cópias dos folders. A principal preocupação de todos com relação ao folder, e à própria oficina, era evitar passar a idéia de que as receitas do xampu e do sabão eram “milagrosas”, e que não era necessário mais nada além de utilizá-las. A higiene corporal, principalmente no que concerne à das crianças, foi relatada pelas professoras como uma questão bastante séria a ser tratada com relação à sua saúde.

Em reunião posteriormente realizada com as agentes de saúde, pretendeu-se sensibilizálas sobre a necessidade de um acompanhamento mais criterioso acerca das enfermidades que atingem as crianças do bairro, através de uma observação mais acurada do ambiente doméstico e da análise dos hábitos de higiene que possam favorecer o contágio e a manutenção das patologias. E ainda verificar a eficácia do sabão e do xampu, observando se houve resultados positivos nas residências onde foram utilizados, verificar se as medidas profiláticas ensinadas durante a oficina estão sendo seguidas, orientar o seu seguimento corretamente (nos casos onde isto não ocorreu), e levar as informações básicas sobre essas enfermidades e seu combate às famílias que não tiveram acesso ao folder e nem estiveram na oficina. 
Foтo 12. Fazendo o xampu - Oficina do sabão e do xampu - Casa da Sopa.

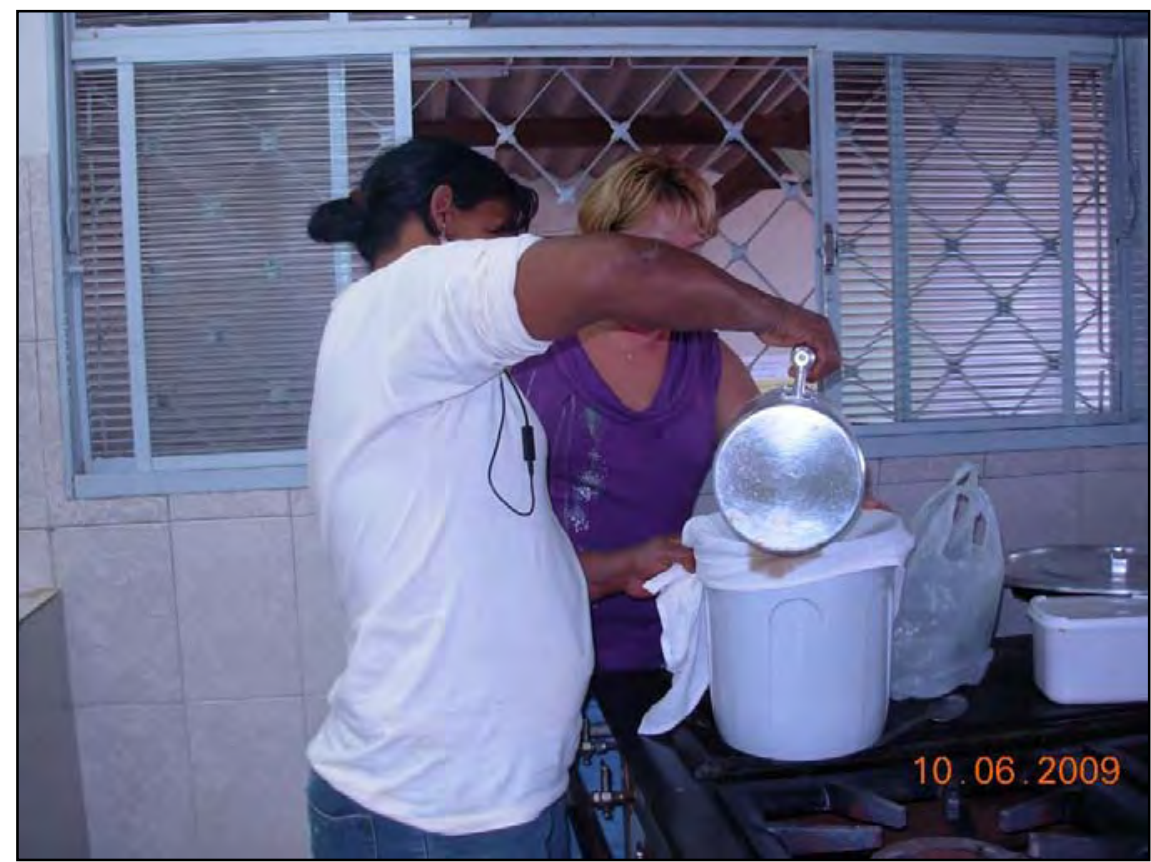

Autora: Torrezan, R. M.

Foi realizada ainda a divulgação da Oficina de forma ampla com todas as crianças da escola, que puderam participar com perguntas e sugestões acerca da escabiose e da pediculose, e sobre suas formas de contágio. A EMEIF contribuiu também convidando os pais dos alunos para a Oficina, através de bilhetes levados para casa pelas crianças.

FOTO 13. Participação da comunidade - Oficina do sabão e do xampu - Casa da Sopa.

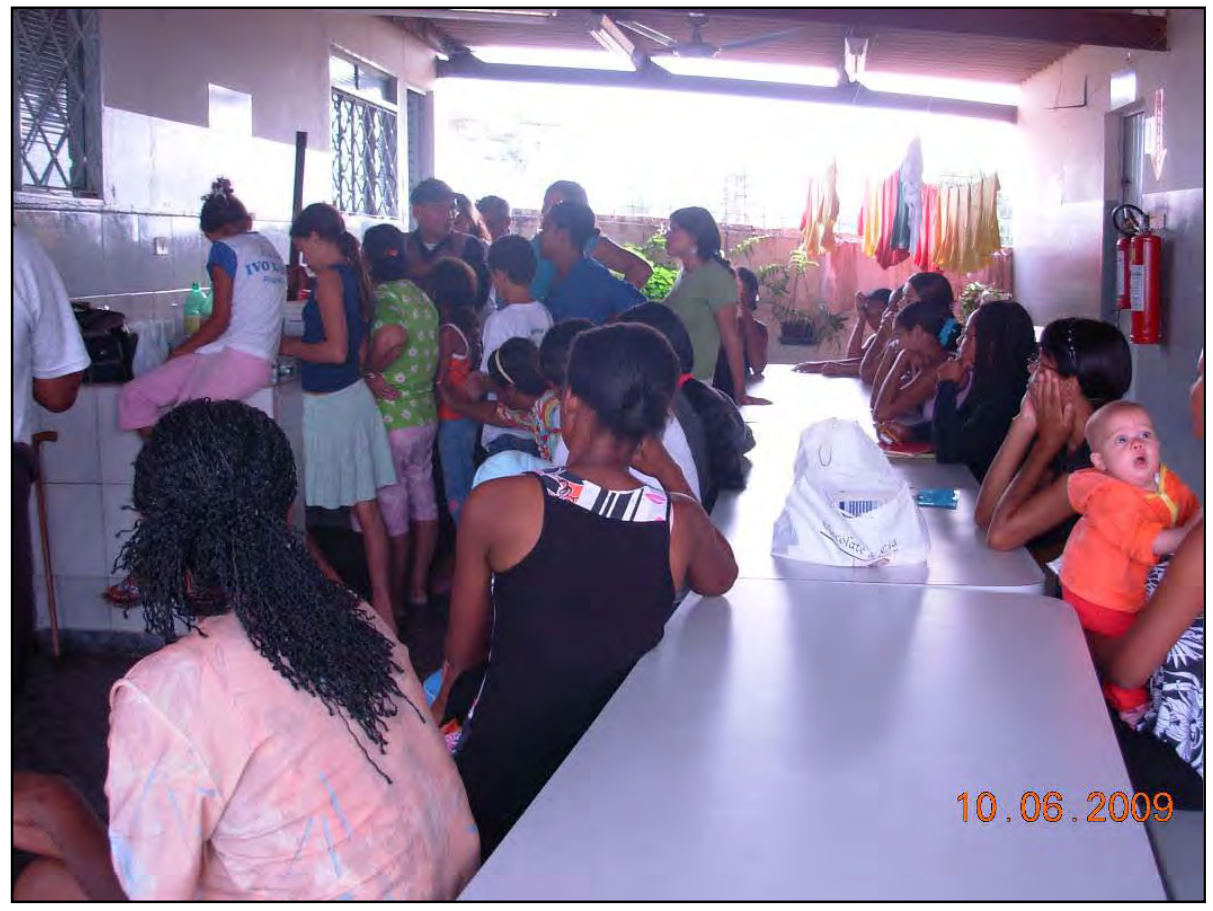

Fonte: Trabalho de campo - jun. 2009 


\section{A $2^{\text {a }}$ Oficina - ensinando na EMEIF.}

Uma preocupação essencial a respeito da Oficina realizada era sobre a eficiência do sabão e do xampu. Tivemos que esperar alguns dias até obtermos as impressões das pessoas que utilizaram as receitas caseiras. Após duas semanas, os membros da Governança Local eram detidos nas ruas pelas pessoas, para dizer que tanto o sabão quanto o xampu tinham sido eficazes no combate à sarna e ao piolho.

A segunda Oficina aconteceu na EMEIF (Escola Municipal de Educação Infantil) “Odete Duarte da Costa”, por solicitação da equipe escolar, já que ninguém desta equipe havia participado da Oficina anterior. O objetivo era aprender a fazer o sabão escabicida e o xampu para piolhos para serem usados na escola, durante o banho dos alunos. Cabe ressaltar que a adaptação do sabão para uso humano depende somente num reajuste da quantidade de enxofre, que é um dos seus ingredientes. A equipe escolar responsabilizou-se pela compra dos ingredientes, e a Oficina foi realizada na escola, que dispõe do fogão e demais utensílios necessários para fazer o xampu e o sabão.

FOTO 14. $2^{\text {a }}$ Oficina do sabão e do xampu - EMEIF.

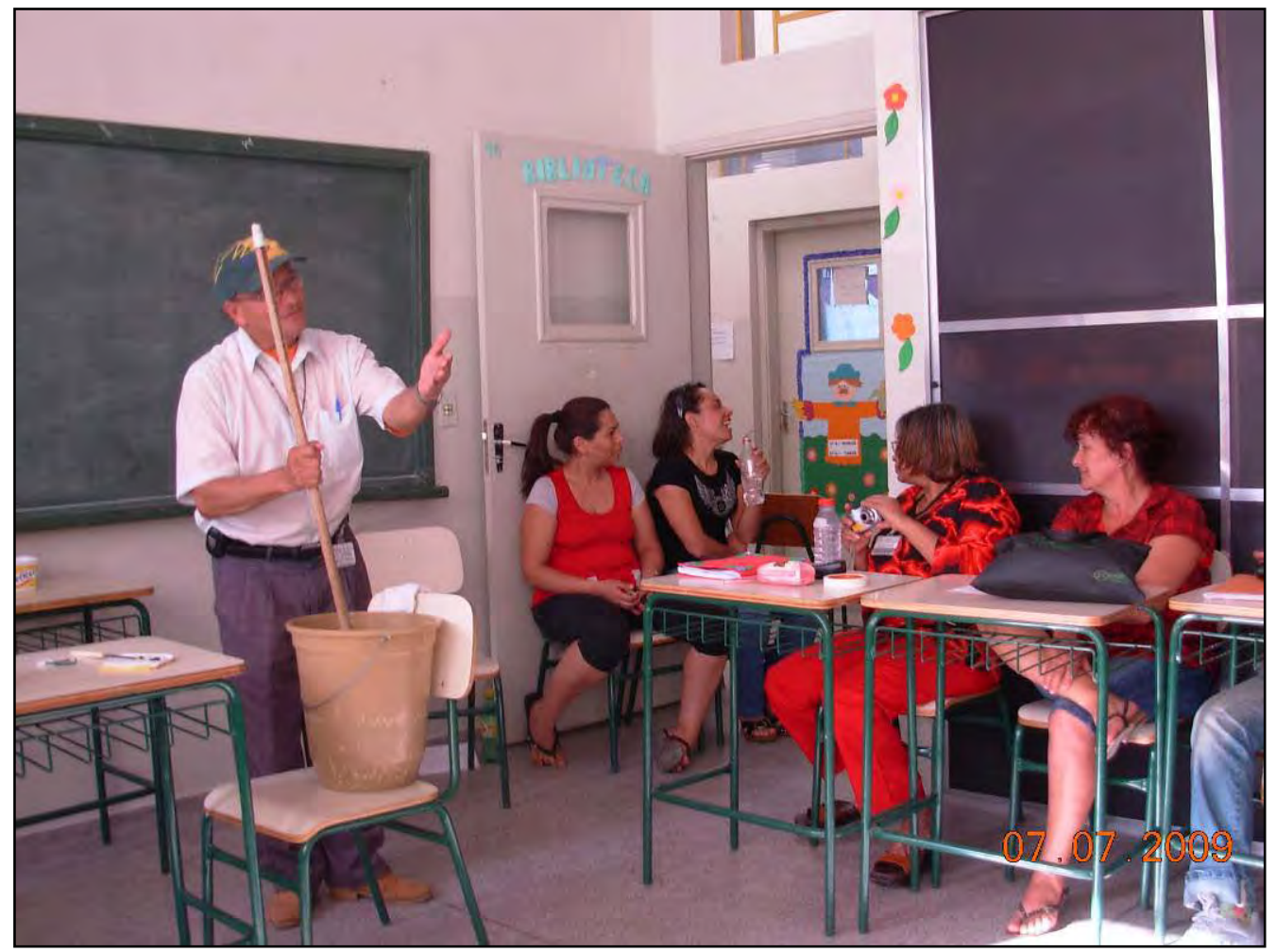

Autora: Torrezan, R. M. 
Houve a solicitação, por parte dos professores, a respeito de uma receita caseira e natural para problemas de garganta e otimização da voz. Experiente em trabalhos comunitários, o participante da Governança Local que nos ensinava a fazer o sabão aproveitou a ocasião para ensinar também a receita do xarope para “limpar” a garganta.

Seguindo as mesmas etapas de trabalho da primeira oficina, o resultado foi, além do sabão e do xampu, uma otimização da parceria entre os membros da escola e da Governança Local.

A equipe escolar estuda a possibilidade de convocar as mães periodicamente para a repetição da Oficina, para efetivar a divulgação dos procedimentos necessários a um melhor cuidado da saúde das crianças.

FOTO 15. Participação da equipe escolar - Oficina do sabão e do xampu - EMEIF.

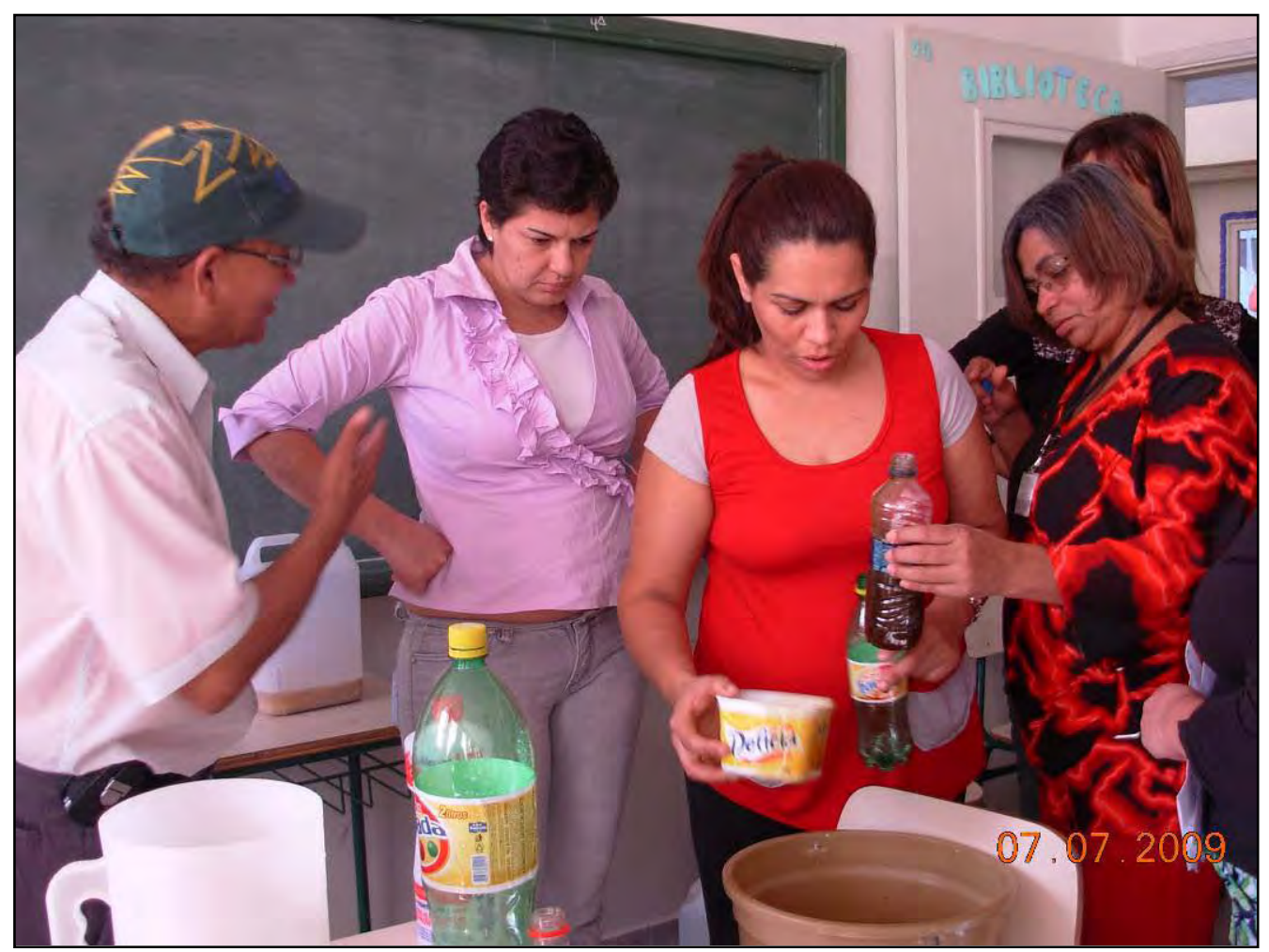

Autora: Torrezan, R. M. 
FOTO 16. Mexendo o sabão - Oficina do sabão e do xampu - EMEIF.

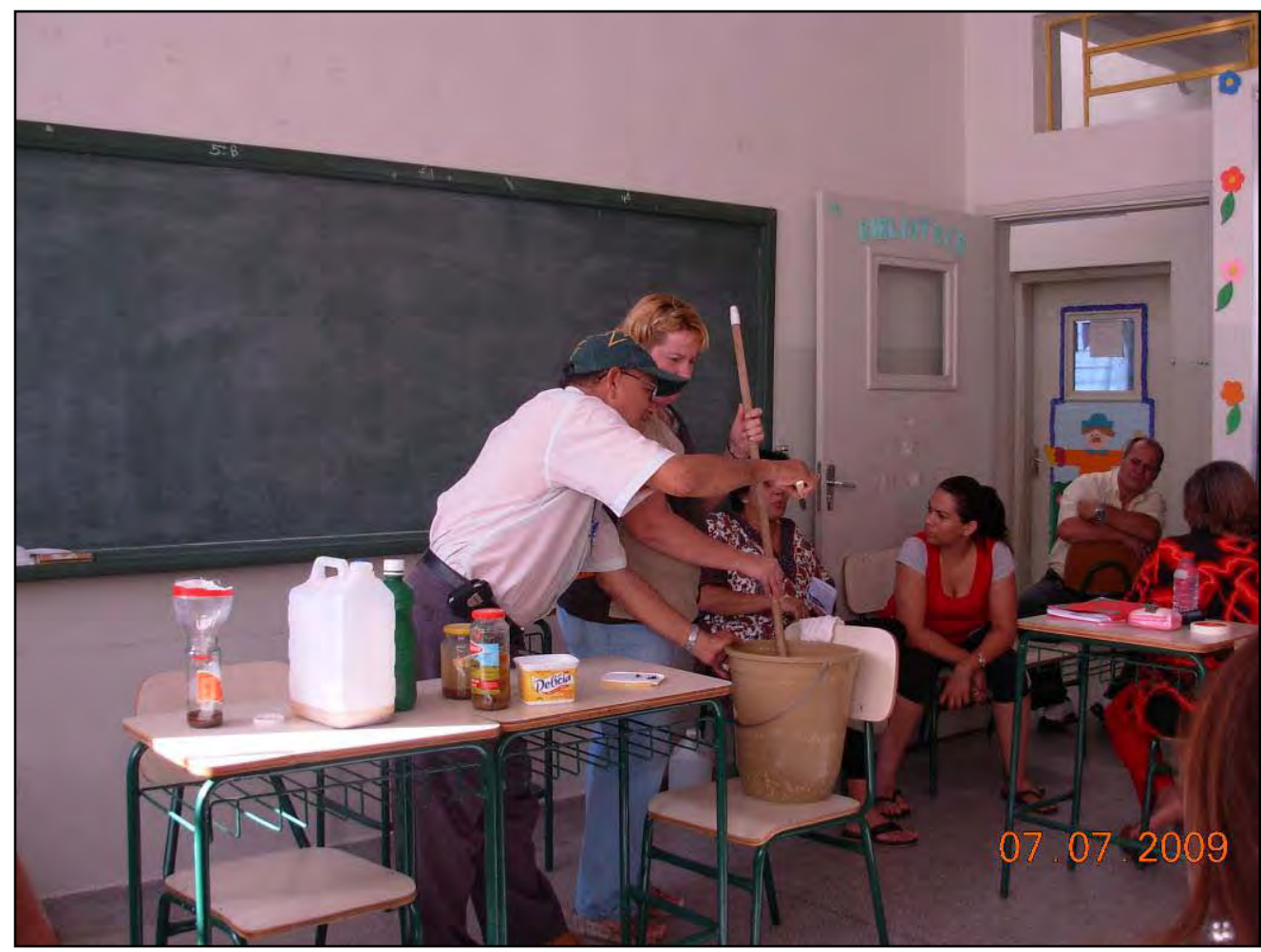

Autora: Torrezan, R. M.

FOTO 17. O sabão - Oficina do sabão e do xampu - EMEIF.

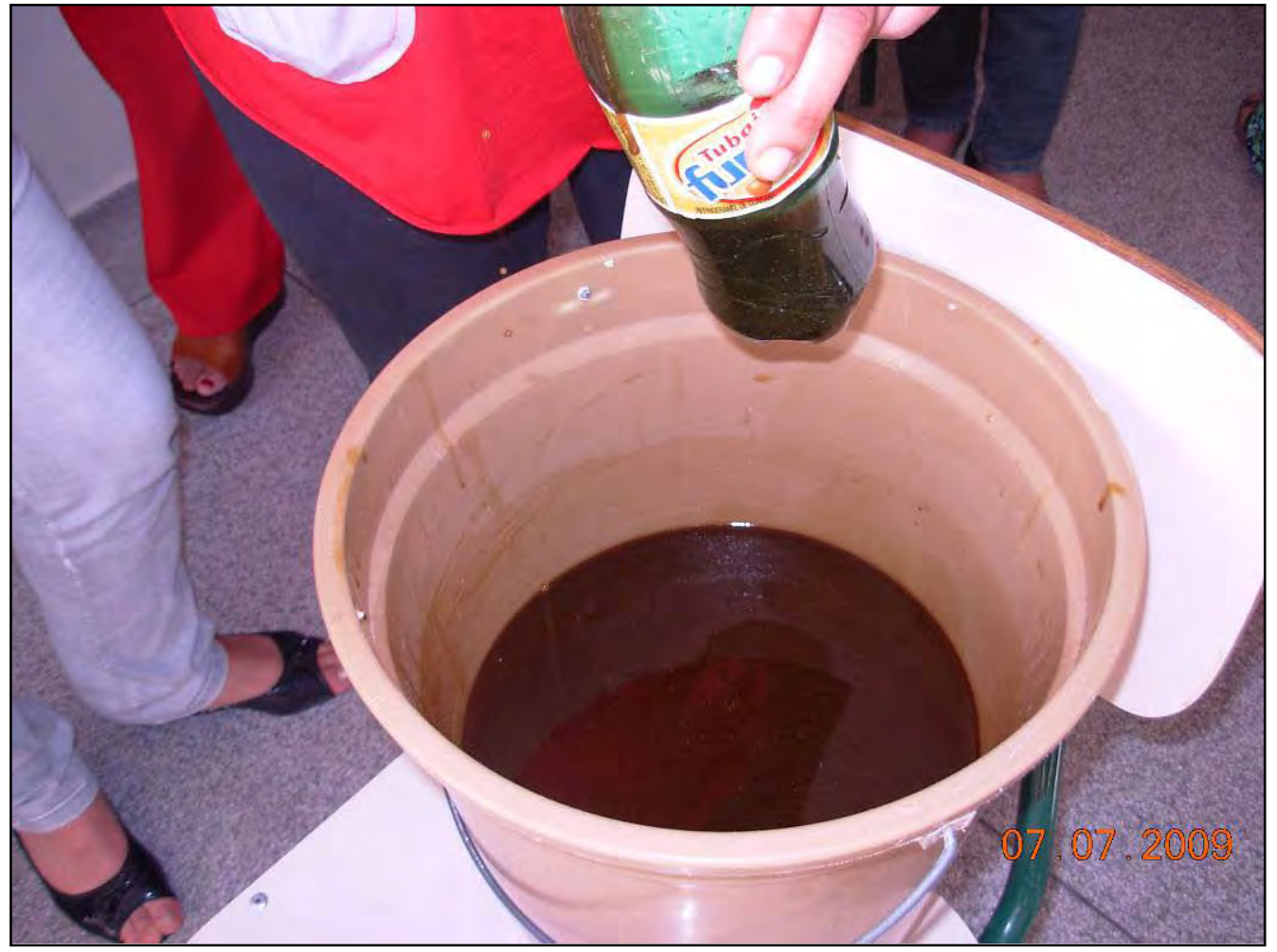

Autora: Torrezan, R. M. 


\section{A $3^{\text {a }}$ Oficina - a pomada e o xarope “da vovó”.}

Esta foi uma oficina que partiu da oferta de um antigo membro da Pastoral da Criança, que dispunha dos conhecimentos necessários para fazer uma pomada cicatrizante caseira, e um xarope para tosse e bronquite, também caseiro, receitas antigas, daquelas chamadas “da vovó”.

O Senac não participou desta oficina, sob a alegação que o ensino de remédios caseiros poderia causar problemas com o Conselho Regional de Farmácia. A discussão foi levada para a reunião, durante a qual refletiu-se sobre o motivo de não se poder ensinar receitas de remédios caseiros, baseados nos conhecimentos antigos de pessoas da comunidade ${ }^{2}$. Decidiu-se por realizar a oficina mesmo com a abstenção do Senac.

Na oficina, novamente a união de sentidos ensejou o diálogo sobre saúde com a comunidade. Fazendo a pomada e o xarope, falou-se sobre as ervas e suas propriedades medicinais, orientou-se sobre seu uso pelas mulheres grávidas, e também a utilização por crianças. As receitas também foram entregues à população (Anexo 4).

FOTO 18. $3^{\text {a }}$ Oficina - Oficina do xarope e da pomada - Casa da Sopa.

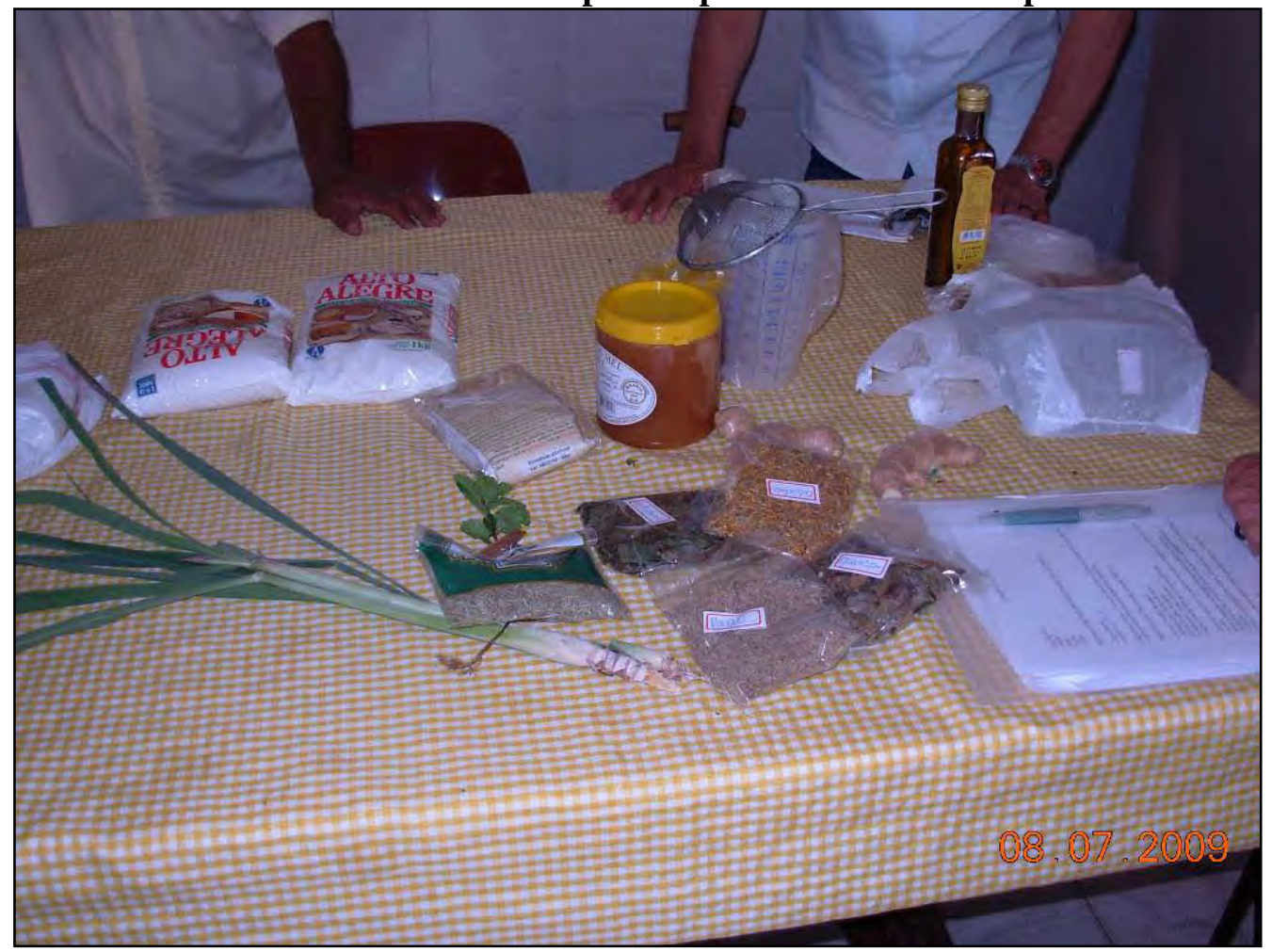

Autora: Torrezan, R. M

\footnotetext{
${ }^{2}$ Embora, em nosso caso, as pessoas responsáveis pela oficina fossem pertencentes à outra comunidade. Trata-se da D. Mazília e do Sr José, moradores da COHAB, e especializados em Bioenergética. Seus trabalhos foram desenvolvidos em conjunto com a Pastoral da Criança durante muitos anos em comunidades carentes de toda a cidade, sendo por isto bastante reconhecidos.
} 
As oficinas têm provocado reações nos dois bairros: as pessoas que compareceram solicitaram a repetição delas e demonstraram claramente que querem mais; as que não puderam participar por se terem realizado em seus horários de trabalho solicitaram mudança de horário.

O objetivo de convocar para o diálogo, e para todos aprendermos juntos foi alcançado. Ainda há muito que avançar, mas a Governança e demais membros da comunidade ensejam uma busca, procuram um caminho de transformação dos bairros: de sua saúde, de suas ruas, de sua aparência, de suas vidas. O importante é que estão empreendendo esta jornada juntos.

Ponto de partida e também de chegada de trabalhos comunitários é o compromisso ético e social, o que leva a pensar os trabalhos na perspectiva de melhoria da qualidade de vida das pessoas. Por isso mesmo, o retorno à comunidade dos resultados do trabalho não se dá exclusivamente no compartilhamento de informações. Antes, e mais do que isso, se dá na efetiva contribuição social. Essa contribuição não deve ser prevista somente na justificativa do trabalho, mas também na sua metodologia, e ela deve ser posta com clareza para os grupos com os quais se trabalha, e conscientizar a todos de que ela não é unilateral - todo mundo ensina e todo mundo aprende: é recíproca. Quando se realiza trabalhos na busca do diálogo com o outro aprende-se a convivência e com ela, aprende-se sobre o outro e sobre mim, a gostar de si e da vida. Aprendese pessoalmente e profissionalmente, com isto ganha a pessoa que convive e ganha o conhecimento que se produz. Aprende-se, essencialmente, sobre humanidade e que, como seres humanos, somos ricamente diversos e iguais (OLIVEIRA, 2003).

\section{Fото 19. Aprendendo sobre as ervas - Oficina do xarope e da pomada - Casa da Sopa.}

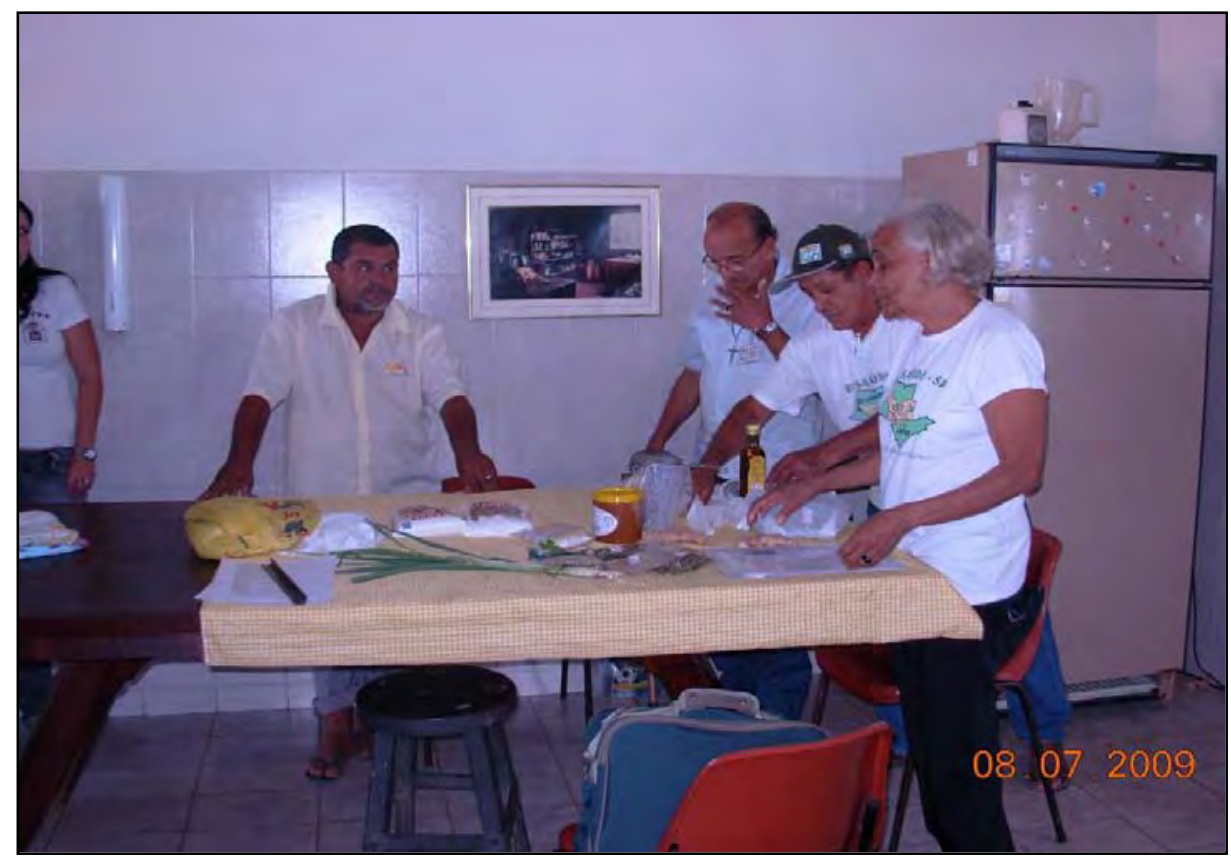

Autora: Torrezan, R. M. 


\section{CAPÍTULO 4. DISCUTINDO OS CAMINHOS DA SAÚDE PÚBLICA NOS BAIRROS.}

“Quando eu cheguei (no Morada do Sol), não tinha água, não tinha luz, a gente morava assim, a luz era de lamparina. (...) Tinha cada cobrona...”.

M. S., ex-moradora.

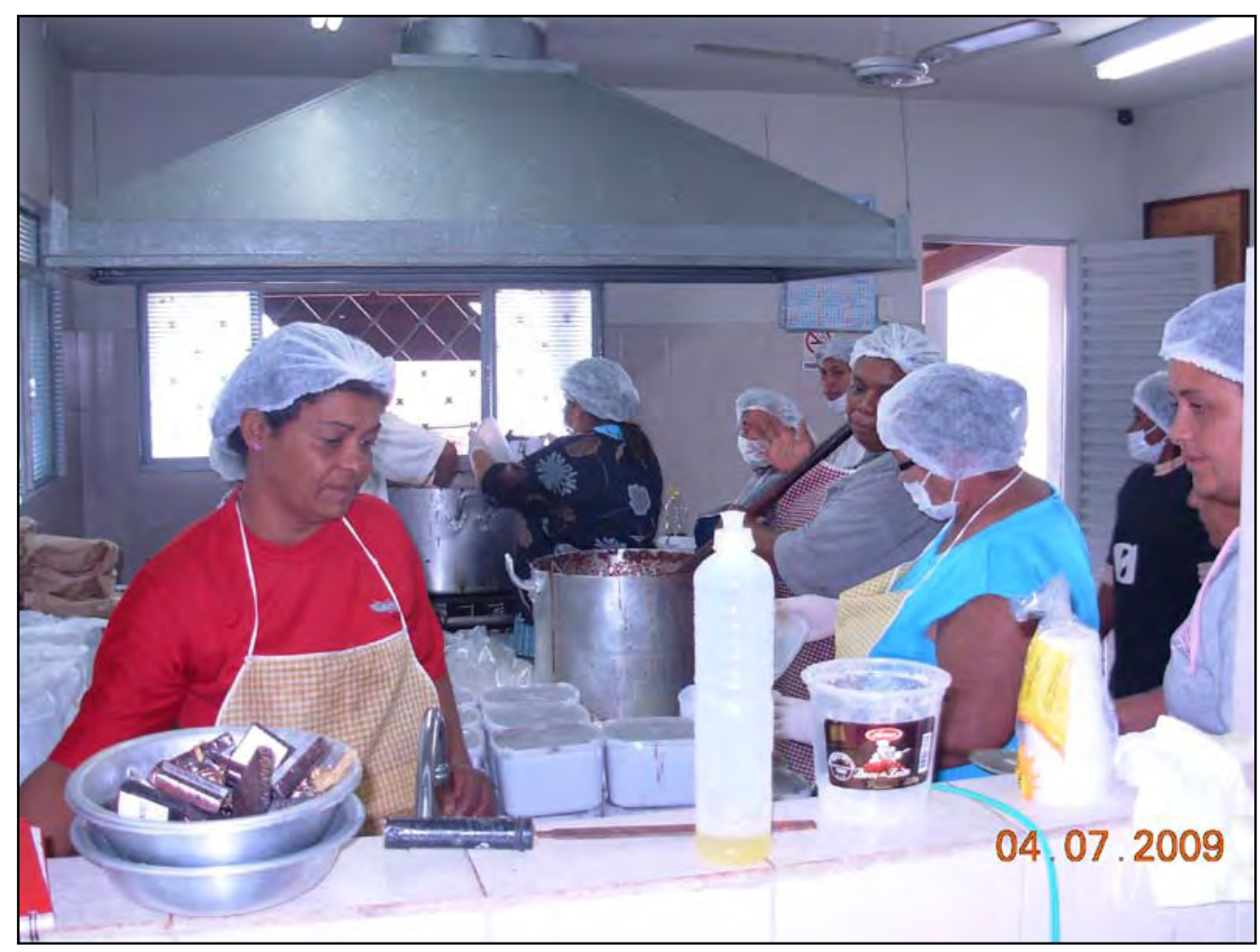

Feijoada - Casa da Sopa - Julho de 2009 Autora: Torrezan, R. M. 
Peço licença para retomar, aqui, a fala pessoal, uma vez que o objetivo principal deste capítulo é de refletir sobre as ações realizadas em conjunto com a comunidade dos bairros Morada do Sol e Belo Galindo. E para isto torna-se necessária a inclusão da pessoa da pesquisadora, inclusive na forma da linguagem, uma vez que as impressões e as emoções que acompanharam a pesquisa e lhe deram forma não são, e nem poderiam ser, de forma alguma, impessoais.

Era a tarde quente de uma segunda-feira de março de 2008, quando cheguei à Casa da Sopa. Eu não imaginava a importância desta entidade assistencial para o bairro, ou melhor, para as pessoas do bairro e sua identidade. Um bairro só adquire identidade própria através das pessoas que nele vivem suas histórias, suas memórias, seus valores. O bairro, enquanto espaço imanente de vivência cotidiana, está evidentemente imbuído dos saberes, dos fazeres e “quereres” de sua gente.

\section{Entrei.}

Fui recebida por Tereza, sorriso franco, acolhedor: “Olha, a Rose hoje não tá, ela vem amanhã pra reunião”. Fui informada que a Rose, responsável pela administração da Casa da Sopa, falaria comigo no dia seguinte, antes da reunião comunitária.

No dia seguinte, uma terça-feira, compareci à reunião com antecedência. Novo sorriso, novo acolhimento. Segundo me explicou, sobre a reunião a ocorrer dentro de alguns minutos, tratava-se do Programa de Desenvolvimento Local, ligado ao Programa de Redes Sociais do Senac, que pretendia trabalhar diversos projetos junto à comunidade do bairro, através de reuniões semanais para a discussão coletiva dos pontos a serem privilegiados. Era uma oportunidade única para iniciar meu trabalho com a comunidade do bairro, embora eu não soubesse exatamente de que forma seria conduzido este programa, e nem se eu seria bem-vinda nele como colaboradora.

Durante a reunião, fui gentilmente convidada a falar por Cláudia, mediadora de redes sociais do Senac. Expus o motivo de minha presença no bairro, e comentei a pesquisa com as moscas. “Ah, eu sei quem você é, sabia que já tinha te visto, tem uma árvore perto da minha casa aonde você ia, com mais uma colega, catar mosca. Que nojo, credo! Pra quê, aquilo?”. "É, e porque no nosso bairro?”. "Você não vem falar pra gente sobre isso?”.

Concordei imediatamente, embora preocupada com o que eu ia fazer.

A verdade é que eu estava indo para o bairro com uma concepção “bancária” de educação. Concepção que Paulo Freire (2005, p.65-66) critica, dizendo: 
Quanto mais analisamos as relações educador-educandos, na escola, em qualquer de seus níveis (ou fora dela), parece que mais nos podemos convencer de que estas relações apresentam um caráter especial e marcante - o de serem relações fundamentalmente narradoras, dissertadoras. (...)

A narração de que o educador é sujeito, conduz os educandos à memorização mecânica do conteúdo narrado. Mais ainda, a narração os transforma em "vasilhas", em recipientes a serem "enchidos” pelo educador. (...)

Desta maneira, a educação se torna um ato de depositar, em que os educandos são os depositários e o educador o depositante.

Normalmente, procura-se sistematizar os tipos ideais de Educação em Saúde de acordo com duas categorias, conforme propõe Albuquerque (2003):

QUADRO 6. SISTEMATIZAÇÃO DOS TIPOS IDEAIS DE EDUCAÇÃO EM SAÚDE

\begin{tabular}{|c|c|c|c|c|}
\hline Tipos ideais & $\begin{array}{l}\text { Modelo de } \\
\text { atenção à saúde }\end{array}$ & Integralidade & Intersetorialidade & $\begin{array}{c}\text { Ações de } \\
\text { Promoção da } \\
\text { Saúde }\end{array}$ \\
\hline $\begin{array}{l}\text { Educação Bancária } \\
\text { na Saúde ou } \\
\text { monológica }\end{array}$ & $\begin{array}{l}\text { - Reforça o modelo } \\
\text { clínico, individual, } \\
\text { flexneriano. } \\
\text { - Não valoriza as } \\
\text { terapias tradicionais } \\
\text { e o saber da } \\
\text { comunidade }\end{array}$ & $\begin{array}{l}\text { - Trabalhada } \\
\text { apenas como } \\
\text { integração entre } \\
\text { prevenção e } \\
\text { assistência }\end{array}$ & $\begin{array}{l}\text { - Utiliza para } \\
\text { atender às } \\
\text { necessidades da } \\
\text { saúde; } \\
\text { - Ações pontuais, } \\
\text { mediadas pelas } \\
\text { representações do } \\
\text { poder público } \\
\text { - Não há interesse } \\
\text { na autonomia da } \\
\text { comunidade }\end{array}$ & $\begin{array}{l}\text { - Referenciadas nas } \\
\text { mudanças de } \\
\text { comportamento } \\
\text { individual } \\
\text { - Trabalhadas } \\
\text { através do repasse } \\
\text { de informações } \\
\text { (depósito de regras } \\
\text { nos pacientes) }\end{array}$ \\
\hline $\begin{array}{l}\text { Educação Popular } \\
\text { em Saúde ou } \\
\text { dialógica }\end{array}$ & $\begin{array}{l}\text { - Questiona o } \\
\text { modelo clínico, } \\
\text { individual, } \\
\text { flexneriano; } \\
\text { - Propõe um novo } \\
\text { modelo baseado na } \\
\text { participação do } \\
\text { usuário, na } \\
\text { promoção da saúde, } \\
\text { na integralidade; } \\
\text { - Valoriza as } \\
\text { terapias tradicionais } \\
\text { e o saber da } \\
\text { comunidade }\end{array}$ & $\begin{array}{l}\text { - Trabalha a } \\
\text { integralidade como } \\
\text { a integração: } \\
\text { • Indivíduo-coletivo } \\
\text { • Promoção- } \\
\text { assistência } \\
\text { • Vigilância - } \\
\text { assistência } \\
\text { • Dos níveis de } \\
\text { complexidade do } \\
\text { SUS } \\
\text { • Ações } \\
\text { intersetoriais }\end{array}$ & $\begin{array}{l}\text { - Usa como } \\
\text { instrumento para } \\
\text { discussão política e } \\
\text { mobilização } \\
\text { popular; } \\
\text { - Ações planejadas } \\
\text { e contínuas } \\
\text { - Propõe-se a } \\
\text { construir a } \\
\text { autonomia da } \\
\text { comunidade } \\
\text { - Incorpora como } \\
\text { ação de saúde }\end{array}$ & $\begin{array}{l}\text { - Referenciadas na } \\
\text { busca de melhores } \\
\text { condições de vida, } \\
\text { incluindo moradia, } \\
\text { saneamento, } \\
\text { trabalho, lazer, } \\
\text { alimentação, etc. } \\
\text { - Trabalhadas em } \\
\text { atividades de } \\
\text { grupo, pelo ciclo da } \\
\text { vida, partindo do } \\
\text { conhecimento do } \\
\text { usuário, } \\
\text { respeitando seu } \\
\text { saber, sua cultura, } \\
\text { suas crenças. }\end{array}$ \\
\hline
\end{tabular}

Fonte: Albuquerque, P.C. A Educação Popular em Saúde no município de Recife-PE: em busca da integralidade. Recife, 2003. 
Mas, apesar de tudo, eu ia com boa intenção. Acredito veementemente que a Universidade pode e deve desempenhar este papel, o de socializar os conhecimentos por ela produzidos. É seu dever transmitir conhecimentos, sim, mas eu sabia, não deve ser só isso.

Para Freire (2005), na concepção “bancária” da educação, a única margem de ação que se oferece aos educandos é a de receberem os depósitos, guardá-los e arquivá-los. No fundo, porém, os grandes arquivados são os homens, nesta equivocada concepção "bancária” da educação. Arquivados, porque, fora da busca, fora da práxis, os homens simplesmente não podem ser. Educador e educandos se arquivam na medida em que, com esta distorcida visão da educação, não há lugar para a criatividade, não há espaço para a transformação, então não há saber. "Só existe saber na invenção, na reinvenção, na busca inquieta, impaciente, permanente, que os homens fazem no mundo, com o mundo e com os outros. Busca esperançosa também” (FREIRE, 2005, p.67).

Devo admitir que, segundo e de acordo com as minhas boas intenções, eu tinha respostas prontas para a comunidade do bairro: onde e como jogar o lixo para evitar a infestação de moscas; como proceder a respeito dos alimentos, da higiene, etc.

Acontece que as perguntas da comunidade eram outras. E o fato é que nem mesmo eles sabiam da profundidade de suas dúvidas - nossas verdadeiras indagações constituem território por vezes nebuloso, ao qual só é possível descortinar através de muito diálogo e reflexão coletiva - através da problematização.

Conforme enfatiza Furlanetti (2009), se problematizar pode nos levar à melhor compreensão da realidade, a problematização começa, então, quando quebramos o silêncio através das perguntas. No silêncio, não existe a compreensão da realidade, por isto é tão importante levantarmos desafios que levem às perguntas. "Perguntas são dúvidas e elas existem a partir do momento em que percebemos que não sabemos, mas que temos o espaço do diálogo, o espaço da voz” (FURLANETTI, 2009, p. 28).

Paulo Freire (1985, apud FURLANETTI, 2009) diz que não existem perguntas bobas e nem respostas definitivas. O educador jamais pode desrespeitar pergunta alguma, mesmo que pareça ingênua ou mal formulada, a fim de não castrar a curiosidade do educando e possibilitar ao educador inserir-se definitivamente no movimento interno do ato de conhecer. A pergunta nunca é ingênua e mal formulada para quem a faz. Por isto, o papel do educador reside em auxiliar o educando a refazer a pergunta, e com isto o educando aprende, fazendo a melhor pergunta.

Estas considerações trazem-me à memória o início de minha participação nas atividades coletivas do bairro, colaborando com o mutirão de limpeza. Os moradores queriam 
limpar o bairro. Para eles, tudo de ruim que caracterizava o bairro advinha da sua fama de "sujo".

Como preparação para o mutirão, então, o Senac, através do Projeto de Educação Sócio-Ambiental “Educando para Renovar” (atrelado ao Programa de Desenvolvimento Local) programou uma série de palestras e atividades a serem conduzidas pela Vigilância Sanitária e Vigilância Epidemiológica do Município.

Apesar da boa intenção (sempre a boa intenção) das palestrantes, o resultado, em termos de conhecimento, foi pífio. Isto porque as pessoas faziam perguntas que eram sumariamente ignoradas ${ }^{3}$.

Faundez (1985, apud FURLANETTI, 2009) confirma e declara a necessidade de o educador, fundamentalmente, valorizar em toda a dimensão o que constitui a linguagem, ou as linguagens, que são linguagens de perguntas antes de serem linguagens de respostas. Isto porque a linguagem manifesta-se de variadas formas: gestual, corporal, de movimento de olhos, de movimento de coração. Não as podemos negar, pois não ouvindo nem valorizando todas as formas de linguagens, estaremos eliminando grande parte da linguagem humana.

Para Freire e Faundez, o educador não deve dar respostas descritivas ao fato perguntado, mas procurar explicitar a relação dinâmica entre palavra e ação, ou melhor, entre palavra-ação-reflexão. Assim, falar, agir, conhecer seriam ações que caminhariam juntas (FURLANETTI, 2009).

A problematização envolve, portanto, a reflexão, isto é, pensar sobre determinadas situações e questioná-las de modo a compreender a maneira como os processos são desencadeados (BRASIL, 2005a). Vale ressaltar que tal reflexão deve acontecer no coletivo, pois dessa forma identificam-se com maior fidedignidade os problemas presentes num determinado local, além de estimular a participação de todos os sujeitos (BRASIL, 2005b).

Um elemento fundamental para permitir a reflexão é o respeito entre o educador e o educando, que se expressa através do diálogo. Conforme Luckesi (1994), pelo diálogo é possível horizontalizar as relações. Para Freire (1996), não há educação se não há diálogo, pois para que o processo educativo aconteça é fundamental que exista uma comunicação. A verdadeira comunicação só ocorre por meio do diálogo.

Freire (2005) cita diversos aspectos que favorecem o diálogo: o amor; a humildade afinal a auto-suficiência é incompatível com o diálogo -; a fé nos homens e no seu poder de fazer e refazer, de criar e recriar; a esperança (pois a esperança é fruto da imperfeição do homem, que

\footnotetext{
${ }^{3}$ Ver páginas $80-81$.
} 
o coloca numa eterna busca, a qual não se faz no isolamento, mas na comunicação); e o pensamento crítico, o qual busca superar a visão ingênua, a acomodação.

Entretanto, deve-se considerar o papel do educador enquanto tal, presente numa comunidade de bairro. Apesar de a tendência educacional progressista ser permeada de elementos que visam à autonomia dos sujeitos, ela não exclui ou reduz a figura do educador, pelo contrário. Para Freire (2002), o educador é indispensável à prática pedagógica, a qual só se completa quando há outro sujeito de conhecimento, o educando. Por isso, Freire (2002, p.83) afirma que o educador e o educando não são iguais. "Quando alguém, como educador, diz que é igual a seu educando, ou é mentiroso e demagógico, ou é incompetente. Porque o educador é diferente do educando pelo próprio fato de ser educador.”

Embora a função do educador seja educar, esse jamais deve perder a consciência de que, ao educar, também se educa (FREIRE, 2002). Ao valorizar a figura do educador, a pedagogia de Paulo Freire revela-se diretiva. Segundo este autor toda educação é diretiva. Entretanto, o educador não deve utilizar o conhecimento que detém para manipular os educandos. O contrário também não deve ocorrer, isto é, em respeito à capacidade crítica e reflexiva dos educandos não se pode deixá-los entregues a si mesmos (FREIRE, 2002).

Conforme o andamento dos trabalhos, fomos percebendo juntos a raiz dos problemas que afligiam aquela comunidade. Ao falarmos, durante o colóquio, sobre as doenças provocadas pelas moscas, as pessoas começaram a refletir e a observar onde e como estas doenças se manifestavam. Decidiram ir até o PSF obter dados estatísticos, e descobriram que eles não existiam. Como, então, obteriam os dados? Poderiam elaborar um questionário sobre saúde ambiental? Porque eram recebidos com negligência no posto de saúde? Porque amigos e vizinhos afirmavam não terem recebido as visitas das agentes?

As perguntas foram crescendo, tornando-se cada vez maiores, mais abrangentes, mais exigentes. Das inter-relações originadas nos diálogos coletivos emergiam as dúvidas, descortinavam-se as interrogações. Revelavam-se os anseios através das palavras antes estancadas pelo silêncio - e estas revelações transformaram o processo de conhecimento da realidade. Isto porque, segundo Freire (2007, p. 61), “A realidade concreta nunca é, apenas, o dado objetivo, o fato real, mas também a percepção que dela se tenha”.

Segundo Freire (2005), para que a educação promova transformações na sociedade, ela deve ocorrer continuamente; dessa forma, é preciso reconhecer que o homem é um ser inacabado. A inconclusão humana é própria da experiência de viver. Além do homem, a realidade é inacabada, assim como tudo no mundo. 
No entanto, somente o homem tem consciência da sua inconclusão, e somente há educação porque o homem é inacabado; essa é a raiz da educação. O inacabamento do homem o coloca em uma constante busca. Logo, pode-se dizer que a educação é essa constante busca; dessa forma, o homem é sujeito de sua educação e não objeto dela (FREIRE, 2001b).

Essa procura do homem pelo conhecimento deve ocorrer no intuito de ele querer ser mais e não ter mais. De acordo com as palavras de um morador:

Aqui, na comunidade, vemos a participação e a importância do ser humano, e não a do ter humano. No mundo de hoje, é o ter que importa, mas nessa comunidade não é o ter, e sim o ser, a doação do tempo e do esforço de cada um, juntando força para conseguir um bairro melhor.

Para tanto, ela não se deve dar na exclusividade, no isolamento, no individualismo, mas na solidariedade, na comunhão (FREIRE, 2005). Parafraseando Freire (2001b, p.28) “O Homem não é uma ilha. É comunicação”.

Nesta empreitada empreendida pelos que agiam no bairro (o Senac, a Casa da Sopa, a comunidade, eu e os demais parceiros) em busca da comunicação, acabamos todos por parar no PSF e na escola. E descobrimos, juntos, o abismo existente entre as duas instituições. Geograficamente próximas (uma em frente à outra); taticamente separadas.

Fomos para a escola. Mergulhada em seus problemas técnico-administrativos (falta de recursos humanos, materiais e financeiros), entraves profissionais (sobrecarga de trabalho dos professores, diretora e demais profissionais, que acumulam cargos na tentativa de obter ganhos mais dignos), a escola manifesta sua angústia traduzida no isolamento. Ficou evidente a necessidade de sua participação nas reuniões comunitárias, mas tornou-se igualmente clara a impossibilidade de fazê-lo: a rigidez do funcionamento escolar praticamente não permite que seus profissionais ultrapassem seus muros. "Concretada” em normas, horários e regras administrativas; soterrada sob montanhas de projetos (que vêem prontos da Secretaria Municipal de Educação), afogada sob uma avalanche de conteúdos e disciplinas desconectados do contexto social em que se situa, a escola permanece imobilizada diante das demandas sociais, educacionais e de saúde de suas crianças.

Preocupadas, muitas das professoras aproveitavam nossa presença para desabafar sobre os problemas de saúde dos alunos. Não entendem porque os piolhos, a sarna e as bicheiras ainda continuam a afligir seus alunos de forma tão violenta: todo o conteúdo sobre saúde, de todas as séries, foi amplamente trabalhado!

Só podemos inferir, daí, que o esforço das professoras produziu informação, e não conhecimento, porque foi um conteúdo trabalhado de maneira distante da realidade dos alunos. 
Ele não foi contextualizado, e por isto não houve comunicação com os educandos. E ela é fundamental na relação professor-aluno, pois segundo Freire (2007, p. 76):

(...) somente na comunicação tem sentido a vida humana. Que o pensar do educador somente ganha autenticidade na autenticidade do pensar dos educandos, mediatizados ambos pela realidade, portanto, na intercomunicação. Por isto, o pensar daquele não pode ser um pensar para estes nem a estes imposto. Daí que não deva ser um pensar no isolamento, na torre de marfim, mas na e pela comunicação, em torno, repitamos, de uma realidade.

E existe maior "torre de marfim" do que os HTPCs (Horários de Trabalhos Pedagógicos Coletivos), em que somente os professores participam? Isolados dos alunos, de seus problemas cotidianos e de sua realidade, isolados do esforço da comunidade para superar ou minimizar estes mesmos problemas, isolados e sozinhos, quais resultados almejam alcançar?

Procuramos argumentar nesse sentido, mas a diretora, embora gentil e solícita, afirmou ser praticamente impossível a participação delas em nossas reuniões.

Para Luckesi (1994, p. 66), aprender é “[...] um ato de conhecimento da realidade concreta, isto é, da situação real vivida pelo educando, e só tem sentido se resulta de uma aproximação crítica dessa realidade.” O aprendizado não resulta da memorização, mas da apropriação critica do objeto, a qual se faz pela compreensão da realidade e reflexão crítica sobre ela.

Luckesi (1994) apresenta três formas de intervenção da educação, traduzidos por sentidos atribuídos pela sociedade, expressos pelos seguintes conceitos: educação como redenção, educação como reprodução e educação como um meio de transformação da sociedade.

A educação redentora considera a sociedade como um conjunto harmonioso, em equilíbrio, e reconhece a existência de grupos que estão à margem dessa harmonia, isto é, deslocados da sociedade. Nesse contexto, a educação tem o objetivo de integrar os indivíduos ao todo social. Para tanto, atua na formação da personalidade do indivíduo para o desenvolvimento de suas habilidades e para a veiculação dos valores éticos necessários à convivência social. Percebe-se que nessa lógica a educação redentora assume uma importante autonomia. Ao invés da sociedade interferir na educação, é ela que interfere nos destinos do todo social - na verdade, uma forma ingênua de compreender a relação da educação com a sociedade.

No segundo sentido, o da educação reprodutora, a educação é um elemento da sociedade, faz parte dela e portanto a reproduz. Diferente da anterior, a educação neste entendimento serve à sociedade; ela não possui autonomia como na primeira. A educação reprodutora tem uma postura de submissão à ideologia dominante, pois acredita que a educação é genuinamente produto da determinação dos condicionantes econômicos, sociais e políticos da 
sociedade. Assim, nada pode ser feito para que a educação se desenvolva de outras formas. A educação reprodutora não propõe um modo de agir, mas apenas demonstra como ela se desenvolve na sociedade.

Para o autor, a educação reprodutora está intimamente relacionada à reprodução da força de trabalho. Para garantir a produtividade da sociedade capitalista, a educação atua no sentido de oferecer conhecimentos técnicos (ler, escrever, fazer cálculos, entre outros), como também de determinar o comportamento dos sujeitos. "A reprodução da força de trabalho exige não só uma reprodução da qualificação desta, mas, ao mesmo tempo, uma reprodução da submissão desta à ideologia dominante” (LUCKESI, 1994, p. 44). Em outras palavras, a educação reprodutora da sociedade oferece conhecimentos, mas dentro dos limites impostos pela ideologia dominante.

A educação transformadora, por sua vez, não reproduz, tampouco redime a sociedade. O referido autor afirma que ela atua criando um projeto de sociedade, o qual pode ser de conservação ou de transformação. Ao contrário das duas tendências anteriores, a educação transformadora reconhece seu papel ativo na sociedade, mas também assume os condicionantes histórico-sociais. Ela valoriza a ação pedagógica inserida no contexto social.

Daí a dificuldade em implementá-la. Educadores e alunos pertencem a contextos completamente diferentes, com referências culturais e de vida totalmente distanciados. A dificuldade reside em transpor o "fosso cultural" que divide educadores e educandos, para que possam seguir juntos.

Da mesma maneira, Stotz (2001) aborda os percursos da população em busca da cura e a relação entre os diversos saberes médicos. Para ele, um fosso cultural separa o médico dos doentes, originando uma inversão perversa em que “a doença precede o doente”, e a busca de superação destes limites deveria envolver-nos como atores (e autores) políticos na dinâmica histórica da sociedade. O autor afirma, com isto, a necessidade de os sistemas médicos aprenderem a pensar os doentes em suas relações, contextos e representações, e no dizer do autor, em seus modos de "andar a vida”. Trata-se de um modo radicalmente diferente de conceber a saúde e a doença, e de organizar os serviços de atenção à saúde. Mais além, implica em envolver-se com a vida das pessoas e, neste sentido, com a mudança das condições propiciadoras da doença. Stotz (2001, p. 134) enfatiza:

Temos de empenhar-nos neste compromisso. Seu nome é utopia: o movimento real pelo qual enfrentamos e conseguimos (com maior ou menor sucesso), ou não, resolver determinados problemas sociais, ou aspectos destes, deslocando a fronteira entre realidade e possibilidade. 
Na realidade que enfrentávamos, havia mais de um fosso: um entre a escola e o PSF, e outro entre os profissionais de ambas as instituições e a população local. E o primeiro passo na direção de superar este obstáculo foi dado pela população, que insistiu com veemência na participação da escola nas reuniões.

Foram liberadas duas professoras por vez, mas sua participação ocorreu somente em duas reuniões, pois seus horários não eram compatíveis.

Contudo, esta exígua participação revelou-se de suma importância, pois dela resultaram as oficinas realizadas, a do xampu para combater piolhos e a do sabão para combater a sarna.

Iniciamos, assim, a nossa "pedagogia do sabão”, no dizer do educador Tião Rocha ${ }^{4}$, uma pedagogia pautada nas necessidades dos educandos, e fundamentada no princípio do nãodesperdício.

O fato é que a pessoa pobre, da comunidade carente, não pode desperdiçar. Antes de ser uma questão de princípio de preservação ambiental (que pode e deve estar presente também, porque não?), é uma questão de sobrevivência. O que dá para aproveitar? Porque não aproveitar? Por que comprar remédio caro para piolho e para sarna na farmácia, se podemos fazer remédios caseiros, de baixo custo, e que são eficientes e econômicos?

Da oficina do sabão e do xampu, surgiram novos questionamentos: se podemos aproveitar muitas coisas, porque não aproveitar o lixo como fonte de renda? Porque não podemos ter coleta seletiva no bairro? Como podemos montar uma cooperativa de catadores de recicláveis? Muitas reuniões paralelas ocorreram, e as discussões a este respeito estão em andamento.

No meio tempo em que as oficinas eram realizadas (posteriormente, optou-se por realizar uma que ensinasse a receita de um xarope para tosse e bronquite e de uma pomada cicatrizante $^{5}$ ), os questionários estavam sendo impressos, e o diálogo com o PSF para sua aplicação era iniciado.

Ao revelar-se o completo desinteresse do PSF pelas ações da comunidade, ao se recusarem a aplicar os questionários, as antigas suspeitas se confirmaram: o PSF, através da atitude distante de seus profissionais, simplesmente não atingia os objetivos que compõem esta estratégia de cuidados à saúde.

\footnotetext{
${ }^{4}$ Tião Rocha, criador da Pedagogia da Roda e da escola embaixo do pé de manga, em entrevista à revista Carta na Escola, Caderno de Sustentabilidade, n. 27, jun/jul de 2008, conta como surgiu a “pedagogia do sabão”, a partir das necessidades imediatas da comunidade.

${ }^{5}$ Ver p. 102.
} 


\subsection{O Programa Saúde da Família ${ }^{6}$}

A Saúde da Família é entendida como uma estratégia de reorientação do modelo assistencial, operacionalizada mediante a implantação de equipes multiprofissionais em unidades básicas de saúde. Estas equipes são responsáveis pelo acompanhamento de um número definido de famílias, localizadas em uma área geográfica delimitada. As equipes atuam com ações de promoção da saúde, prevenção, recuperação, reabilitação de doenças e agravos mais freqüentes, e na manutenção da saúde desta comunidade.

A partir da promulgação da Constituição Federal em 1988, foram definidas como diretrizes do Sistema Único de Saúde (SUS) a universalização, a eqüidade, a integralidade, a descentralização, a hierarquização e a participação da comunidade. Ao ser desenvolvido sobre esses princípios, o processo de construção do Sistema Único de Saúde visa reduzir o hiato ainda existente entre os direitos sociais garantidos em lei e a capacidade efetiva de oferta de ações e serviços públicos de saúde à população brasileira.

O modelo assistencial ainda predominante no país, caracterizado pela prática “hospitalocêntrica”, pelo individualismo, pela utilização irracional dos recursos tecnológicos disponíveis e pela baixa resolubilidade, gera alto grau de insatisfação para todos os partícipes do processo - gestores, profissionais de saúde e população que utiliza os serviços.

Como conseqüência, o bom senso milenar do "prevenir para não remediar” foi sendo reescrito com o abandono da prevenção e promoção da saúde em todas as suas dimensões.

Visando, enquanto estratégia setorial, a reorientação do modelo assistencial brasileiro, o Ministério da Saúde assumiu, a partir de 1994 a implantação do Programa Saúde da Família PSF.

Em alguns contextos, ela se motivou mais pelo resgate de valores profissionais; em outros, pela capacidade de melhorar os indicadores de saúde e reordenar o modelo assistencial.

O Programa Saúde da Família representa tanto uma estratégia para modificar a forma atual de prestação de assistência à saúde como uma proposta de reorganização da atenção básica como eixo de reorientação do modelo assistencial, respondendo a uma nova concepção de saúde não mais centrada somente na assistência à doença mas, sobretudo, na promoção da qualidade de vida e intervenção nos fatores que a colocam em risco - pela incorporação das ações programáticas de uma forma mais abrangente e do desenvolvimento de ações intersetoriais.

\footnotetext{
${ }^{6}$ Texto elaborado com base na publicação da SECRETARIA DE POLITICAS DE SAUDE. Departamento de Atenção Básica. Programa Saúde da Família. Rev. Saúde Pública [online]. 2000, vol.34, n.3, pp. 316-319. ISSN 0034-8910.
} 
Caracteriza-se pela sintonia com os princípios da universalidade, eqüidade da atenção e integralidade das ações. Estrutura-se, assim, na lógica básica de atenção à saúde, gerando novas práticas e afirmando a indissociabilidade entre os trabalhos clínicos e a promoção da saúde.

Testado em diversos países com contextos culturais de diferentes dimensões e níveis diferenciados de desenvolvimento socioeconômico, como por exemplo Canadá, Reino Unido e Cuba, o modelo de atenção preconizado pelo Programa Saúde da Família demonstrou eficiência, resolvendo mais de $85 \%$ dos casos - o percentual restante destina-se a unidades mais complexas. Além do mais, o programa permite uma forte integração entre o Ministério, as secretarias estaduais, os municípios, a comunidade local e outros parceiros, em benefício de todos.

A estratégia do PSF indica uma nova dinâmica para a estruturação dos serviços de saúde, bem como para a sua relação com a comunidade e entre os diversos níveis de complexidade assistencial. Com o compromisso de prestar assistência universal, integral, equânime, contínua e, acima de tudo, resolutiva à população, na unidade de saúde e no domicílio, identifica os fatores de risco aos quais ela está exposta, neles intervindo de forma apropriada.

O PSF concebe ações combinadas a partir da noção ampliada de saúde, englobando aspectos capazes de levar a pessoa a ser mais feliz e produtiva - e se propõe a humanizar as práticas de saúde, buscando a satisfação do usuário pelo estreito relacionamento dos profissionais com a comunidade, estimulando-a ao reconhecimento da saúde como um direito de cidadania e, portanto, expressão e qualidade de vida.

Uma das principais estratégias do Saúde da Família é sua capacidade de propor alianças, seja no interior do próprio sistema de saúde, seja nas ações desenvolvidas com as áreas de saneamento, educação, cultura, transporte, entre outras. Visa uma transformação interna do sistema, buscando a reorganização das ações e serviços de saúde, o que implica na ruptura da dicotomia entre as ações de saúde pública e a atenção médica individual, bem como entre as práticas educativas e assistenciais.

Configura, ainda, uma concepção inovadora de trabalho, através de uma nova forma de vínculo entre os membros de uma equipe, diferentemente do modelo biomédico tradicional, permitindo maior diversidade das ações e busca permanente do consenso. O papel do profissional de saúde, sob esta perspectiva, passa a ser o de aliar-se à família no cumprimento de sua missão, fortalecendo-a e proporcionando o apoio necessário ao desempenho de suas responsabilidades (jamais tentando substituí-la).

Tal relação de trabalho baseia-se na interdisciplinaridade e não mais na multidisciplinaridade, associada à não-aceitação do refúgio da assistência no positivismo 
biológico. Para tanto, requer uma nova abordagem que questione as certezas profissionais e estimule a permanente comunicação horizontal entre os componentes de uma equipe.

Um dos principais objetivos é a geração de práticas de saúde, nas quais haja integração das ações clínicas e de saúde coletiva.

E para que essa nova prática se concretize, faz-se necessária a existência de um profissional com visão sistêmica e integral do indivíduo, família e comunidade, um profissional capaz de atuar com criatividade e senso crítico, mediante uma prática humanizada, competente e resolutiva, envolvida nas ações de promoção, de proteção específica, assistencial e de reabilitação. Profissional, esse, capacitado para planejar, organizar, desenvolver e avaliar ações que respondam às reais necessidades da comunidade, articulando os diversos setores envolvidos na promoção da saúde, realizando uma permanente interação com a comunidade, no sentido de mobilizá-a, estimular sua participação e envolvê-la nas atividades.

Com vistas ao alcance dos objetivos propostos, as equipes devem ser compostas por, no mínimo, um médico de família, um enfermeiro, um auxiliar de enfermagem e cinco a seis agentes comunitários de saúde - outros profissionais, tais como psicólogos, dentistas, fisioterapeutas, por exemplo, poderão ser incorporados de acordo com as características e demandas dos serviços locais de saúde. Cada equipe é responsável pelo acompanhamento de, no máximo, mil famílias ou 4.500 pessoas que residam ou trabalhem no território de responsabilidade da unidade de saúde, agora denominada "Unidade Básica de Saúde da Família”.

Um dos caracteres de diferenciação desse processo é que os profissionais das equipes de saúde devem residir no município onde atuam, trabalhando em regime de dedicação integral. Por sua vez, para garantir a vinculação e identidade cultural com as famílias sob sua responsabilidade, os agentes comunitários de saúde (ACS) também devem residir nas respectivas áreas de atuação.

Responsabilidades da equipe do PSF.

As atribuições básicas de uma equipe de Saúde da Família são:

- conhecer a realidade das famílias pelas quais são responsáveis e identificar os problemas de saúde mais comuns e situações de risco aos quais a população está exposta;

- executar, de acordo com a qualificação de cada profissional, os procedimentos de vigilância à saúde e de vigilância epidemiológica, nos diversos ciclos da vida;

- garantir a continuidade do tratamento, pela adequada referência do caso; 
- prestar assistência integral, respondendo de forma contínua e racionalizada à demanda, buscando contactos com indivíduos sadios ou doentes, visando promover a saúde por meio da educação sanitária;

- promover ações intersetoriais e parcerias com organizações formais e informais existentes na comunidade para o enfrentamento conjunto dos problemas;

- discutir, de forma permanente, junto à equipe e à comunidade, o conceito de cidadania, enfatizando os direitos de saúde e as bases legais que os legitimam;

- incentivar a formação e/ou participação ativa nos conselhos locais de saúde e no Conselho Municipal de Saúde.

\subsection{Buscando a interação necessária.}

Notadamente, a equipe do PSF presente nos bairros estudados difere bastante daquela preconizada pela Secretaria de políticas de Saúde. Primeiramente, pelo fato de as agentes de saúde não serem moradoras do bairro. Conforme o documento, esta seria uma condição fundamental para a garantia da integração entre o trabalho destes profissionais e as pessoas por eles atendidas.

A luta da Governança Local para incluir a equipe do PSF em seus trabalhos relacionados à saúde da população residente nos bairros é emblemática e demonstra claramente o completo distanciamento dos profissionais membros da equipe com relação aos problemas de saúde que afligem as pessoas as quais deveria assistir.

A respeito das ações de cunho intersetorial e interdisciplinar a situação é a mesma: não há conexão com os serviços de educação, muito menos com os de vigilância sanitária e epidemiológica.

Para O’Dwyer, ; Tavares.; De Seta (2007), a equipe de saúde da família pode (e deve) ser o elo entre a comunidade e a equipe de vigilância sanitária. O agente comunitário é o primeiro profissional com o qual a comunidade se identifica. Ele deve ter liderança junto à comunidade, além de percepção do contexto social e geográfico onde a comunidade está inserida. É ele quem primeiro consegue identificar situações de risco, norteadoras para a epidemiologia e para a prevenção, assim como para a vigilância sanitária. Diversas situações de risco, algumas de graves conseqüências para a saúde, como descontinuidade de tratamento, abandono de idosos, negligência com crianças, alcoolismo, migração excessiva, desemprego e outras, são cotidianamente identificadas por esses profissionais e abordadas por toda a equipe de saúde da família. É, portanto, de extrema necessidade incorporar, ao seu olhar, situações de risco 
ou agravo de importância para a vigilância sanitária, tais como: intoxicação alimentar, contaminação do ambiente, riscos trabalhistas, uso inadequado de medicamentos, entre outros.

Não se pode ignorar que a humanização da assistência acontece no dia-a-dia, no encontro do usuário com o profissional e a equipe. A educação, proposta enquanto ferramenta deve reconhecer sua ideologia emancipadora de uma nova relação, no desafio de investir em recursos humanos, transformando em prática a comunicação com a população e seu exercício de cidadania (O’DWYER, ; TAVARES., DE SETA, 2007).

Operacionalizar o conceito de integralidade não é tarefa simples. É uma mudança, não só de estratégia ou de reorientação de modelo de atenção, mas de valor, onde o usuário não sinta que esse sistema é excludente, e que o favorece ao ofertar serviços mais próximos de suas necessidades, e sim que esses serviços são um direito que lhe pertence. E que a equipe humanize seu trabalho ao abster-se do exercício do poder na sua relação com o usuário. Somente assim estaremos frente ao fortalecimento da ação comunitária e de um novo espaço de interlocução (O’DWYER, ; TAVARES., DE SETA, 2007).

Não podemos negar o grande avanço da Estratégia Saúde da Família no Brasil, ao longo dos últimos anos, no entanto, a cobertura da saúde da família ainda precisa de ampliação. Os processos de capacitação para os profissionais de saúde, infelizmente, ainda são incipientes em algumas regiões do país e insuficientes para as necessidades apresentadas.

\subsection{Entre a teoria e a realidade: $o$ bairro como espaço de identidade.}

O Jardim Morada do Sol foi implementado com o intuito de absorver uma população de baixo poder aquisitivo, população essa proveniente de vários bairros da cidade, que foi realocada para lá pelo Programa de Desfavelamento e Loteamentos Urbanizados da Prefeitura Municipal de Presidente Prudente, no inicio dos anos 1990 (ALMEIDA JUNIOR; WHITACKER, 2007).

O Projeto de Desfavelamento e Loteamentos Urbanizados foi implementado durante a gestão administrativa de Paulo Constantino (PTB - Partido Trabalhista Brasileiro, que exerceu o cargo executivo nos anos de 1989 a 1992). Já a Urbanização de Favelas foi um projeto da gestão administrativa do Prefeito Agripino de Oliveira Lima (PFL - Partido da Frente Liberal, 1993 a 1996), durante o qual foi concedido o Direito Real de Uso (IKUTA, 2003)

Sabe-se que a inexistência oficial de favelas em Presidente Prudente hoje é resultante de um processo bastante conflitivo entre o poder público municipal e o Movimento de Luta pela Moradia entre os anos de 1989 e 1994, contudo: 
A informação relevante aqui é que a intervenção pública (mediada pela confrontação com o Movimento), seja com o deslocamento dos barracos mediante a criação de lotes urbanizados que, na verdade, foi uma política de expulsão das famílias, seja por meio da "urbanização das favelas", ou a "regularização" das áreas faveladas com a concessão do Direito Real de Uso significou, na maior parte das vezes, a intensificação ou no máximo a manutenção das precariedades nas condições de existência dessas famílias. Além disso, não é desmerecido ressaltar a repercussão ideológica que essa intervenção teve por conta da aparente desfavelização da cidade, já que popularmente a favela é a expressão mais explícita do problema da moradia (IKUTA, 2003, p.25).

Os baixos salários (quando não o desemprego) são responsáveis pela ativação de diversas estratégias que possibilitam a sobrevivência das famílias. Algumas delas referem-se ao estabelecimento de relações de reciprocidade entre parentes, conterrâneos, compadres, vizinhos, irmãos de fé... Outras se referem à reativação de práticas típicas do mundo rural, que, são, ao mesmo tempo, expressões da cultura de pessoas advindas do mundo rural. Dentre tais práticas está o cultivo de frutas, verduras e plantas medicinais nos terrenos das residências, mantidas por moradores desempregados, aposentados e donas de casa. Em nossas visitas, foi possível encontrar plantas ornamentais (folhagens e flores), árvores e arbustos frutíferos (pinha, manga, limão, mamão, banana, goiaba, mexerica, laranja, limão), verduras e legumes (couve, alface), uma diversidade de temperos e ervas medicinais e até mesmo alguns cereais, como o milho.

Encontramos a revificação destes hábitos rurais não apenas nos terrenos das residências, mas também nos cultivos em áreas públicas, nos diversos terrenos cultivados com verduras e legumes para o comércio, nas galinhas soltas pelas ruas ainda sem asfaltamento e nas cabras e cabritos pastoreando pelo bairro.

A manutenção destes cultivos em diversos espaços (residências, áreas públicas, terrenos comerciais), a criação destes animais para o abate e consumo do leite (como no caso das galinhas e das cabras), reconstrói a ambientação do mundo rural, ao mesmo tempo em que serve para reduzir os custos com a feira semanal, o gasto na padaria e mesmo nas farmácias. Foram indicados pela Governança Local diversos moradores que cultivam grande variedade de ervas medicinais que doam aos vizinhos adoentados.

Ansiando pela imagem "limpa” do bairro, o costume de criar animais para consumo da carne e do leite foi uma preocupação constante durante a elaboração do questionário. Imbuídos de uma visão influenciada pelos princípios de higienização difundidos pela burguesia no início da industrialização, os moradores tencionavam conseguir o controle destas práticas nos terrenos do bairro. Como forma de resistência ante a precariedade da vida e à destruição da cultura, tais costumes enfrentarão, no espaço da cidade, alguns conflitos com o poder local. 
As precárias condições de moradia, transporte, saúde e educação, a situação de baixa renda e vulnerabilidade social deixam evidente a precariedade e a conflitualidade presente no bairro, tornando difícil a continuidade da ação comunitária. Este aspecto da vida naquele local pode ser exemplificado através das desistências freqüentes dos participantes das reuniões: vários deles desistiram após perderem seus empregos e entrarem e depressão; uma participante perdeu a guarda dos filhos e foi internada para tratamento de dependência química; alguns se mudaram para outras localidades após perderem seus empregos. Outros ainda desistiram durante a colheita de batatas, período em que precisam trabalhar bastante porque não há garantia de trabalho fora da safra.

Diversas questões nos assinalam as possibilidades de apropriação do espaço pelos moradores, muitas das quais apontam para a precariedade da vida, corroborada pela ação de empregadores, empreendedores do setor imobiliário e poder público. As formas de resistência cotidiana empreendida pelos moradores dos bairros estão presentes na revificação de costumes trazidos do mundo rural, na fé religiosa, nas festas que celebram a identidade. Outras são relacionadas à resistência cultural e podem ser remetidas ao último tópico sugerido por Haesbaert (2006), a respeito da “manutenção de sua identidade sociocultural através de espaços específicos, seja para a reprodução de seus ritos, seja como referenciais simbólicos para a ‘reinvenção’ identitária.” (p. 249-250).

O fato é que o Jardim Morada do Sol possui uma história sui generis quando comparada a de outros bairros, fortemente marcada pelo afastamento acentuado da malha urbana compacta da cidade, num distanciamento muito mais do que espacial, conforme lembra M. S., ex-moradora do bairro:

Aí chegando lá, né, aí o que aconteceu? Aquele buracão, só tinha a estrada, tudo de terra, aquele mato ali, tudo nas coisas, isso aquele outro, eu peguei, o que que eu fiz? Nós entramo de cara e coragem, primeiro economizar e construir. Aí não tinha água, não tinha luz. A gente deixava os tambor na frente da porta e o caminhão pipa vinha, deixava a água. Quando você ia trabalhar que você chegava à tarde, ia tomar um banho não tinha mais água, que a molecada e boi ia, e bebia tudo a água. Então você imagine a vida que a gente passamo ali no $\mathrm{km} 7$.

A fala de M. S. é emblemática. E é útil ao nosso propósito de descortinar a formação da identidade do bairro.

Nossa opção por empregar uma parte da narrativa de uma história de vida ${ }^{7}$ vem ancorada numa concepção de memória que a considera como fenômeno social, ponderando que o caráter livre e espontâneo, quase onírico da memória é excepcional e que a vida atual do

\footnotetext{
${ }^{7}$ A de M. S., que estava entre as quatro primeiras famílias a chegar ao bairro quando ele foi implantado, em 1992.
} 
sujeito possui um caráter ativo no desencadeamento do curso da memória. Para Halbwachs, portanto, memória não é sonho, é trabalho. (HALBWACHS, 2006, apud MELO, B. M., 2008).

Ainda, ao utilizarmos da memória para trazer ao presente a lembrança de posições sociais ocupadas no passado, é necessário atentarmo-nos a que "todas as ações do grupo podem ser traduzidas em termos espaciais”, conforme nos lembra Halbwachs em seu livro “A memória coletiva” (2006, apud MELO, B. M., 2008).

Augusto Comte observou que o equilíbrio mental resulta em boa parte e antes de mais nada, do fato de que os objetos materiais com os quais estamos em contato diário não mudam ou mudam pouco e nos oferecem uma imagem de permanência e estabilidade. A força que a memória material (e também espacial) possui sobre a memória coletiva e a memória individual é atestada pelo autor em exemplos os mais diversos e ricos. E como não há memória que não aconteça num contexto espacial é para ele que devemos voltar nossa atenção para que essa ou aquela categoria de lembrança reapareça (MELO, B. M., 2008).

Ah, minha filha, se eu contar minha vida tudo certo é tim-tim por tim-tim, sabe? Foi muito sofrimento mais foi bom, sabe? A gente saía cedo e ia trabalhar na roça. Eu tinha a minha horta, apesar de toda a dificuldade eu tinha a minha horta, cê acredita? E ali foi movimentando, que hoje ta daquele jeito (M. S., ex-moradora).

A história destas vidas, amalgamadas à história do bairro, não é pouca coisa. Essa história é o que imprime identidade própria ao local, uma identidade marcada pelo sofrimento dos que ali primeiro chegaram. Mesmo que a maioria dos que vivenciaram este início sofrido não estejam mais morando ali, através do tempo e do espaço ecoam os seus lamentos, as suas lágrimas, as suas carências:

Não, não existia a Casa da Sopa. Sabe o que eles fazia? Nessa época, a M. (...) ela vinha, trazia a sopa, num carro, num... num pampa, sabe? E eu ajudava ela a sair distribuindo nas casinha, que tinha o quê? Umas dez casa, depois aumentaram, saiu mais... aí tinha aquelas casinha, uma longe da outra, a gente saía entregando lá nas casa, sabe. Aí era roupa, alimento, aí depois saiu a casa, além da Casa da Sopa também tinha outra associação que ajudava muito lá, também, mas não lembro o nome da associação, sabe... Eu lembro que ajudava também (M. S., ex-moradora).

Fundamental é conhecer esta história, sentí-la em sua totalidade, para poder entender essas pessoas e seus motivos, seus desejos e aspirações. Sem essa transcendência necessária, o trabalho educativo se torna impessoal, desprovido de emoção, de esperança, de motivação. Motivação experimentada por uma população que construiu seu próprio bairro, do nada: 
Aí, meu marido ajudou fazer a Casa da Sopa. (...). Ajudou, o S. ajudou a construir lá. Cada tijolo daquele ali ele ajudou também. A maioria ali tudo teve a mão de obra da gente, sabe? (M. S., ex-moradora).

Por trás das mãos, dos olhos e dos braços de quem faz, de quem constrói um bairro, ou o próprio espaço geográfico, existem pessoas que pensam. No seu modo de fazer o espaço, e no modo de rememorar este fazer, está um motivo, uma decisão, que é política e denota a capacidade de resistência destas pessoas. Aceitar a luta, transformar o espaço, manter seus signos identitários - eis a sua forma de resistir. Imprescindível, portanto, entender como, de que maneira pensam estas pessoas, para entender como agem, e de que forma o espaço geográfico é por elas produzido.

Assim, então, o trabalho conjunto de educação em saúde acontece. De verdade.

Este é o momento em que se pode, bem mais do que nos anos sessenta, falar de uma "experiência de Educação Popular na área da saúde”. E ela se realiza quando o trabalho profissional de Saúde Pública funde-se em um trabalho cultural de Educação Popular por meio da Saúde. Quando a ação médica e a de outros profissionais da "área da Saúde" não se limita a uma assistência a clientes do povo. Quando ela se estende a uma ação cultural ampliada de diálogo e de crescimento de parte a parte, em busca de saídas e de soluções sociais a partir do que se vive e do que se troca, do que se aprende e do que se motiva, quando se dialoga crítica e criativamente sobre a vida e o mundo por intermédio do corpo e da saúde (BRANDÃO, 2001, p. 131).

A comunidade dos bairros Jardim Morada do Sol e Residencial Francisco Belo Galindo ainda não logrou seu intento a respeito do funcionamento efetivo e da interação entre os serviços de saúde, educação e meio ambiente em seu bairro. Mas está, novamente, lutando por esta meta. Irá atingi-la? Não sei. Toda luta assemelha-se a uma viagem ao desconhecido, parte-se com muitas idéias, mas quase nunca se encontra exatamente o que se imaginava alcançar. Assim, ao iniciá-la, não se sabe onde se poderá chegar, mas sabe-se seguramente que é preciso, de algum modo, partir. 


\section{5. À GUISA DE CONCLUSÃO.}

“(...) a sempre difícil e inalcançável busca do diálogo - deixa de ser uma simples metodologia de trabalho didático, para vir a ser o fim e o sentido de uma educação conscientizadora.”

Brandão, 2001.

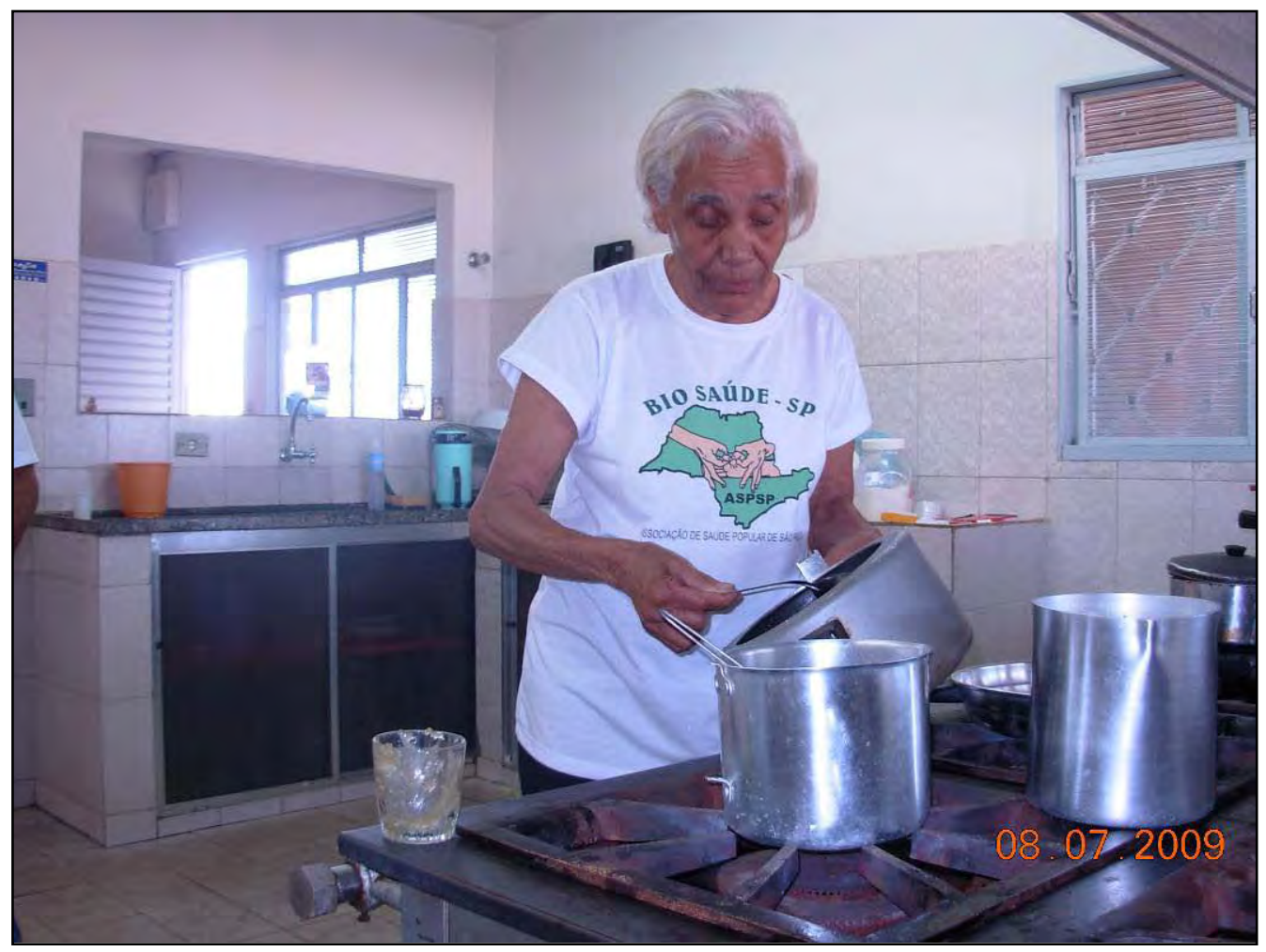

Oficina do xarope e da pomada - Casa da Sopa.

Autora: Torrezan, R. M. 
Enquanto escrevo estas linhas, notícias chegam do bairro: um membro da comunidade ficou doente, outro mutirão de limpeza foi realizado com a participação ativa dos moradores, uma outra oficina (Oficina de Amamentação, realizada pela equipe do PSF em parceria com o Senac) foi um sucesso. Fico inquieta - penso que eu deveria estar lá, registrando tudo, participando...

Mais idéias, mais diálogo, mais reflexões. A semente foi lançada. Conforme a Coordenadora do Plano de Desenvolvimento Local do Senac, Cláudia Dias, afirmou durante o Fórum de Desenvolvimento Local (27 de novembro de 2009, em Presidente Prudente):

Quando a gente começa o trabalho, se preocupa se vai dar certo, se as pessoas vão aderir. No fim, vemos que é uma preocupação inútil. Quando lançamos a semente, as pessoas da comunidade fazem o que precisa ser feito. A gente não precisa tutelar ninguém.

Em vista disso, termino este trabalho, mas não o encerro, no sentido de conclusão. Isto porque as experiências aqui narradas não se concluem, uma vez que constituem um processo em permanente evolução - com erros e tropeços, sim, mas com os quais muito se aprende e melhora ao longo de uma trajetória de conquista de direitos realizada a muitas e diversificadas mãos.

O que fiz foi um estudo exploratório a respeito das possibilidades de se pesquisar ações educativas comunitárias em saúde, sob a perspectiva da Educação Popular em Saúde. E o que apresento a seguir são alguns aspectos desta experiência, que se afigurou como uma história ao leitor. Não há, portanto, um sentido único, uma conclusão definitiva, uma verdade inexorável, nem mesmo algo que possa servir de modelo, como um possível savoir-faire para outras comunidades e/ou pesquisadores. Como em todas as experiências onde se envolvem seres humanos, cada uma delas é única: o que deu certo no Morada do Sol pode não dar em outro bairro; e ações que foram muito bem sucedidas naquele local, em outro podem simplesmente não acontecer.

Contudo, da profusão de sentidos que a esta experiência se possa dar, das interpretações que advirem de sua leitura, das inúmeras reflexões que ela possa suscitar, espera-se que seja perceptível a existência de uma sincera contribuição à fundamental aproximação entre a teoria e a ação, possibilitando a pluralidade de olhares necessária à compreensão de uma realidade multifacetada.

Em busca de uma totalidade científica que permita maior aproximação do real, o desafio maior consiste em lançar mão de múltiplos recursos que permitam pensar esta realidade. 
Nesse sentido, incorporar um olhar sensível, aquele mesmo da poetisa quando nos diz que é necessário ver o mundo através do prisma de um lustre ${ }^{8}$.

Esse olhar inovador, através do prisma de um lustre, permite contemplar o espaço visual e o representacional, evitando a separação entre a dimensão perceptiva e a memorativa e imaginária. Ginzburg (1989, apud SILVA, 2008) chama a atenção para a necessidade de nos determos aos elementos pouco notados na investigação científica. Assim, o autor compara as linhas que compõem a pesquisa aos fios de um tapete, descrevendo a complexidade de sua imensa trama, na qual o desenho só é possível ser visualizado ao voltarmos os olhos a todas as direções. Com Deleuze e Guattarri (1995, apud SILVA, 2008), temos ainda a idéia do rizoma: não há fim nem começo, não remete a uma unidade nem dela deriva, não há sujeito nem objeto. Entra-se por qualquer lado e os pontos se conectam.

Prisma de lustre, tecitura de um tapete, rizoma - são metáforas que nos auxiliam a compreender, a visualizar o movimento da realidade numa proposta dialética que liberta o espaço-tempo de uma única realidade duplicada em oposição e negação. Engloba as coexistências, as possibilidades, o contraditório (SILVA, 2008).

Estas referências possibilitam o olhar múltiplo - e por isso mesmo configuram o olhar como método. Um olhar onde a percepção e a linguagem propiciem a interpretação do real, e considere a plasticidade do tempo como forma de compreender a sucessão dos acontecimentos que engendraram a configuração espacial atual. A percepção pode constituir um caminho espinhoso, pois leva para a representação as dimensões do irreal, da ilusão e do engano. Mas, nesta visão multiespectral, é imperativo considerar que estas dimensões, ao contrário de apontar para o não-real, antes fazem parte do real (SILVA, 2008).

O múltiplo abriga, portanto, o acaso e a imprevisibilidade. A idéia de multiplicidade proporciona o necessário discernimento de que é ambígua a relação entre ciência, não-ciência, ficção e opinião, assim como é tênue o limite entre a realidade e a ilusão (SILVA, 2008).

A Educação Popular em Saúde tem se constituído numa área de interseção entre a educação e a saúde, que afirma o compromisso com uma educação libertadora, que leva o outro a questionar a realidade em que vive e a se engajar no processo de sua transformação. Desta forma, assume-se o seu potencial de discutir o modelo hegemônico de saúde e questionar o papel deste enquanto legitimador da ordem social instituída. Baseado nos princípios da educação popular de

\footnotetext{
${ }^{8}$ Citação efetuada por Silva, Valéria C. P (2008), em sua tese de doutoramento, de um artigo de Cecília Prada sobre o fazer poético de Cecília Meireles, no qual a poetisa afirmava: "tudo quanto naquele tempo vi, ouvi, toquei, senti, perdura em mim com uma intensidade poética inextinguível... céus estrelados, tempestades, chuva nas flores, frutas maduras, casas fechadas, estátuas, negros, aleijados, bichos, suínos, realejos, cores de tapete, bacia de anil, nervuras de tábuas, vidros de remédio, o limo dos tanques, a noite em cima das árvores, o mundo visto através de um prisma de lustre" (Meireles s/d apud. Prada, 2002, p. 29).
} 
Paulo Freire, busca construir um novo saber de forma dialógica, a partir do reconhecimento do saber do outro, no caso da saúde, o usuário, as comunidades, a população.

Nesse sentido, ter como referencial teórico a Educação Popular significou o encontro de duas certezas: as da educação popular e as minhas. Um encontro importante, pois na Educação Popular há um outro encontro, este, para mim, fundamental: pesquisa e militância, que elimina definitivamente a camisa-de-força da falsa neutralidade política do pesquisador. Isto possibilita encarar a pesquisa não como a produção de um conhecimento elitizado, distante do mundo real no qual vivem (e convivem) as pessoas que estão do lado de fora do mundo acadêmico, mas sim como um modo de estar no mundo, pronunciá-lo (no dizer de Paulo Freire) e inserir-se na coletividade com uma clara intencionalidade de conscientização e transformação.

A neutralidade frente ao mundo, frente ao histórico, frente aos valores, reflete apenas o medo que se tem de revelar o compromisso: os que se dizem neutros estão comprometidos consigo mesmos, com seus interesses e com os interesses dos grupos aos quais pertencem. E como este não é um compromisso verdadeiro, assumem a neutralidade impossível (FREIRE, 2001,p.19).

Nas nossas experiências, incontáveis foram os aprendizados e os ensinamentos; o maior deles, o "conviver". E buscamos este "conviver" com tenacidade, pois, concordando com Oliveira (2003, p.123), sabemos que

Conviver é mais do que visitar e não é algo que possa ser delegado, requer um envolvimento pessoal, observando, perguntando e conversando. Essa convivência pode trazer maior confiabilidade a pesquisa pois é nela que os posicionamentos políticos se clarificarão e as pessoas poderão se colocar abertamente. Apenas olhando para ao outro e com ele convivendo é que se pode detectar as posições políticas que atravessam os depoimentos, as conversas e as informações sobre dada realidade. A convivência permitirá perceber o que cotidianamente aflige as pessoas repensando o trabalho coletivo e pensando políticas públicas mais condizentes com a concretude do cotidiano. Consciente das diferenças, o início do convívio - que não se dá numa primeira ida ao outro lugar - deve se cercar de alguns cuidados. O principal deles, de caminhar em companhia de alguém desse lugar. E, aos poucos, conhecer e se fazer conhecer.

O referencial da educação popular, como referencial de partida, exigiu a escolha de um caminhar metodológico onde a pesquisa, enquanto também uma prática social, se desenvolvesse através de um diálogo (na verdade, muitos diálogos) entre sujeitos. Daí as necessárias aproximações, conversas e convivências. Aproximações realizadas na fase inicial da pesquisa, quando íamos colocar as armadilhas para a coleta das moscas, e éramos convidadas a entrar nas casas para tomar um café, invariavelmente acompanhado de “um dedo de prosa”. Conversas, nas 
diversas ocasiões em que encontrávamos pessoas curiosas a respeito da pesquisa com as moscas, sempre querendo saber mais. E convivências, a partir do momento em que iniciei participação efetiva nas reuniões e ações da comunidade. Um processo educativo facilitado pelo movimento recíproco para o diálogo, da pesquisadora e dos demais colaboradores deste estudo.

A compreensão de educação como um processo social, histórico, permite entender com clareza que as práticas sociais estão ininterruptamente permeadas por processos educativos. Mais do que isso, permite entender que, historicamente, outros processos, humanizantes, são possíveis e portanto a pesquisa pode (e deve) contribuir para se pensar essas possibilidades (OLIVEIRA, 2003, p. 121-122).

Nesta direção, de uma busca educativa através do diálogo, pude perceber que havia outros parceiros igualmente empenhados no alcance do mesmo intento, embora cada qual ao seu modo: o Laboratório de Geografia da Saúde e o CEMESPP, em cujas pesquisas de cunho crítico e social encontrei as bases para a investigação engajada na busca da superação de paradigmas científicos anacrônicos, e comprometida com a socialização do conhecimento; o SENAC, através do Projeto de Redes Sociais e Desenvolvimento Local, cujas experiências constituem riquíssima fonte de conhecimento e construção compartilhada da cidadania; a Casa da Sopa Francisco de Assis, envolvida de corpo e alma com a história dos dois bairros e de seus moradores, a tal ponto que em certos momentos elas se confundem; sempre presente, adequando-se às necessidades daquela comunidade, articulando ações e formas de superação dos problemas inerentes a dois bairros distantes da malha urbana, e em sua origem passada excluídos em todos os sentidos que se possa enumerar; o CRAS (Centro de Referência da Assistência Social), cujos trabalhos não se limitam ao auxílio mais do que necessário às carências de toda ordem, mas envolvem uma procura constante e incansável de uma estratégia de trabalho mais abrangente e intersetorial. No mesmo sentido, os demais parceiros, a Equipe de Bethânia, em cujas obras sociais de apoio e oração encontram-se mais do que somente consolo, mas também, e sobretudo, reflexão à luz da fé cristã; o PROAMA (Projeto Amor em Ação) da Igreja Metodista, que trabalha na mesma perspectiva, as Pastorais (da Saúde, da Família e da Criança), a Associação de Moradores, mesmo que muitas vezes conte com membros interessados em promoção política e social, mas que realiza ações importantes dentro da comunidade.

Imprescindível é notar, dentro das entidades, instituições, associações, grupos e comunidades, a coexistência e a atuação das pessoas - elas são as protagonistas desta história. Todas elas preocupadas com o “outro”, com a coletividade, numa visão de mundo mais crítica e consciente, predestinada, por conseguinte, à mudança. Uma mudança que pressupõe, antes de tudo, a reflexão e a ação. 
Destas pessoas recebi lições de vida, de trabalho e de humildade. Pessoas que, apesar de perceberem toda a diferença de sua situação econômica, se movimentam no sentido de alargar os espaços, romper barreiras e conquistar direitos, no sentido de serem reconhecidos e fazer valer seus valores, distanciados dos valores materiais.

E em suas estratégias simples, as conversas eram fluidas, o diálogo sempre permeando as discussões mais importantes. Os conceitos “higienistas” e comportamentais da comunidade a respeito da educação em saúde foram se modificando ao longo das reuniões, as discussões cada vez mais se aproximando das questões que norteiam as políticas públicas de educação, saúde e meio ambiente. Percebeu-se a necessidade de integração entre os setores de educação, saúde e vigilância sanitária na melhoria da saúde da população, integração esta que a comunidade se prepara para alcançar a qualquer custo, utilizando suas principais ferramentas: a da persuasão e a do diálogo.

Outras ferramentas são, ainda, necessárias a esta vivência comunitária: afetividade, respeito, humildade, compreensão, perdão. É preciso também ser flexível, saber ponderar, ouvir o outro. E é preciso participar - efetivamente.

Participar, na perspectiva dialógica, não é fazer o que outros decidem que cabe a mim, e muito menos responder burocraticamente ou apenas formalmente pela participação. É ser sujeito dessa participação. Ir para comunidades nesta perspectiva pode trazer ganhos coletivos e aprendizagens mútuas (OLIVEIRA, 2003, p. 123).

Com estas ferramentas em uso, o grupo cresce, possibilitando novas perspectivas e realizações, descobrindo e trazendo à tona aspectos ignorados (ou escamoteados) pelas estatísticas oficiais (como no caso das bicheiras, dos piolhos e da sarna que afligem as crianças dos bairros, e que simplesmente não aparecem nos registros de saúde do PSF), ou até mesmo contrariando-as - que é o que se intenta conseguir com a aplicação dos questionários, uma batalha ainda em andamento.

As reuniões comunitárias constituem amplo espaço de diálogo entre as pessoas da comunidade, representantes do poder público e instituições diversas, pesquisadores de universidades e lideranças locais, nas quais os membros da comunidade discutem os problemas que atingem a população dos dois bairros, problematizam temas relevantes e propõem estratégias de solução.

É, portanto, através do diálogo que surgem as oportunidades de reflexão coletiva acerca de problemas que são vividos por todos, proporcionando condições para o desenvolvimento de relações sociais mais harmônicas. Este é também o caminho para a constituição de cidadãos e cidadãs mais participativos, mais críticos e, principalmente, mais ativos diante de sua realidade. 
Quando refletem e dialogam sobre um tema, que pode ser "saúde”, ou "ambiente”, na verdade o fio condutor de suas idéias é a reflexão acerca de sua própria realidade, sua condição dentro da sociedade, sendo esta a causa de um determinado fator vir a constituir "problema” para eles, ao mesmo tempo em que se conscientizam que este mesmo fator não constitui problema para outros, pois se encontram em condições sócio-econômicas privilegiadas.

É preciso considerar ainda que, conforme Flecha (1997, apud OLIVEIRA, 2003), um diálogo em condições de igualdade considera as diferentes contribuições em função da força das argumentações, e não das posições de poder de quem as coloca. Os saberes são percebidos de diversas formas, formas que muitas vezes são bem diferentes das formas de comunicação de setores privilegiados. Mas isto não significa que sejam deficientes.

As pessoas da comunidade sabem, elas percebem com clareza sua localização na sociedade e no espaço, e já se movimentam no sentido de transformar esta posição. E esta opção é política.

As atividades investigativas desenvolvidas pelo Laboratório de Geografia da Saúde têm proporcionado a socialização de experiências que conduzem a uma construção compartilhada de conhecimentos contextualizados. Os trabalhos de pesquisa deste laboratório crítico e social têm sido de grande importância para todos que participam deste processo de integração entre pesquisa e comunidade, propiciando que esta última se apoderasse dos conhecimentos científicos gerados e avançasse no sentido de ampliar a sua própria capacidade de problematização e pudesse priorizar os problemas de saúde que mais a afligem e necessitam de intervenção mais urgente: a partir das doenças causadas pelas moscas, chegou-se à escabiose e à pediculose, cujas feridas (causadas pelo ato de coçar) atraem as moscas e provocam as conhecidas “bicheiras”.

Pode-se observar que os participantes da Governança Local, juntamente com os pesquisadores envolvidos, tornaram-se mais conscientes de sua realidade complexa e distinta; e mais conscientes de que toda ação facultativa de êxito desenvolve-se através do trabalho comunitário, interdisciplinar e multiprofissional. Conhecendo, assim, sua própria realidade, participando ativamente da construção deste conhecimento, acabando por constituir-se agente de sua própria história, e não apenas mero espectador. Apoderando-se de saberes científicos sempre negados às pessoas das classes populares, e transformando pesquisadores e pesquisados em aliados de um mesmo trabalho comum, com objetivos comuns, numa aproximação necessária entre Universidade e comunidade.

Há, além e acima de tudo, a necessidade de amar. Tem que haver uma imensa dose de afetividade para que as pessoas se envolvam. Para trabalhar em grupo tem que haver união, e não há união sem respeito, sem amizade, sem aceitação do outro como ele é, mesmo com idéias às 
vezes tão divergentes. E tudo isso não ocorre sem amor: amor entre as pessoas, amor pelo bairro, amor pela comunidade, amor pelo mundo.

Paulatinamente, é nestes espaços de diálogo (e de afetividade) que se constroem as alternativas possíveis de superação da condição de exploração vivenciada pelo grupo, pois concordamos com Freire (2004) quando ele afirma que o exercício da cidadania não é algo mágico. Ao pronunciarmos a palavra cidadania não significa que somos cidadãos. O exercício da cidadania é expressamente um ato político. E este ato político tem que encontrar espaço para se desenvolver. Timidamente, em seu início. Que seja. O essencial é que cresça, atingindo o tamanho dos sonhos das pessoas que nele se engajam, pois, ainda de acordo com Freire (2004), sonhar é uma necessidade humana, tanto que chega a afirmar: “(...) não me é possível simplesmente estar sendo no mundo sem ter amanhã, e não é viável lidar com ele, o amanhã, sem sonhar” (p. 197).

As pessoas do Jardim Morada do Sol e do Residencial Francisco Belo Galindo tem um sonho comum. Um sonho para o seu bairro, para suas vidas naquele lugar. Ele está fixado na parede da sala onde se realizam as reuniões de Desenvolvimento Local, na Casa da Sopa:

Em 2014, o Jardim Morada do Sol e o Residencial Francisco Belo Galindo serão:

“Os bairros mais lindos de Prudente; modelos da cidade; os mais respeitados; com saúde em primeiro lugar e melhor qualidade de vida”.

No cartaz, escrito com letras simples em cartolina branca, está a toda a esperança de uma comunidade. Nele está escrito o que as pessoas desejam: um bairro bonito, agradável para se morar, onde as pessoas sejam unidas, e que constitua um exemplo pra outras comunidades. E, com isto, concordando com Freire (2004, p. 210), quando ele diz: “(...) jamais me permiti não ter esperança, porque a morte da esperança, em muitos sentidos, é a nossa própria morte”.

Consideramos ter atingido nosso objetivo inicial, o de efetuar uma ação educativa em saúde junto à comunidade local, partindo do diagnóstico da situação epidemiológica relativa às espécies de moscas domésticas nos bairros. E, com isto, problematizando as suas condições de saúde e construindo, juntos, uma estratégia de educação em saúde, no sentido da integração dos sistemas de saúde, de educação, sócio-sanitário e de conservação ambiental; possibilitando também, e sobretudo, a sensibilização necessária à compreensão da importância da ação educativa na implementação da política pública de saúde, através da experiência de articulação de atores sociais na resolução dos problemas de saúde da sua própria comunidade. 


\section{Bibliografia}

ALBUQUERQUE, Paulette Cavalcanti. A educação popular em saúde no município do Recife - PE: em busca da integalidade. Tese (Doutorado em Ciências). Escola Nacional de Saúde Pública/Fiocruz, Rio de Janeiro, 2003.

ALBUQUERQUE, P. C.; STOTZ, E. N. A educação popular na atenção básica à saúde no município: em busca da integralidade. Interface - Comunic., Saúde, Educ., v.8, n. 15, p. 259- 74, mar/ago. 2004. Disponível em: http://www.interface.org.br. Acesso em: agosto/2008.

ALMEIDA JÚNIOR, A. R.; WHITACKER, A. M. Segregação socioespacial em cidades médias: diferenças ou semelhanças? Um estudo sobre o Jardim Cinqüentenário e o Jardim Morada do Sol e Presidente Prudente - SP. Geografia em Atos, n. 7, v. 2, Presidente Prudente, 2007.

ASSOGBA, YAO. Introduction à l'analyse de dynamiques organisatinnelles de l'économie social et populaire em Afrique. Cahier de la Chaire de recherche du Canadá en développement des collectivités (CRDC), Université du Québec em Outaouais:, série Recherche no. 33, janvier/2004.

AUGUSTO, L.G.S. et al. Saúde e ambiente: uma reflexão da ABRASCO. Rev. Bras. Epidemiol. Vol. 6, No 2, pp. 87-94, 2003

BARBOSA, R. S.; GIFFIN, K. Gênero, saúde reprodutiva e vida cotidiana em uma experiência de pesquisa-ação com jovens da Maré, Rio de Janeiro. Interface - Comunic., Saúde, Educ., v. 11, n. 23, p. 549- 67, set/dez 2007. Disponível em: http://www.scielo.br. Acesso em: fevereiro/ 2008.

BERTOLLI FILHO, Cláudio. História da Saúde Pública no Brasil. São Paulo: Ática, 1996.

BRANDÃO, Carlos Rodrigues. A educação popular na área da Saúde. Interface - Comunic, Saúde, Educ., n. 8, p 127-131, fev. 2001.

BRANDÃO, C. R. (Org.). Pesquisa Participante. São Paulo: Brasiliense, 2006.

BRASIL. Ministério da Educação e do Desporto. Secretaria da Educação Fundamental. Parâmetros Curriculares Nacionais: pluralidade cultural, orientação sexual. Brasília: MEC/SEF, 1997.

BRASIL. Ministério da Educação e do Desporto. Secretaria da Educação Fundamental. Parâmetros Curriculares Nacionais: Geografia. $5^{a}$ a $8^{a}$ séries do Ensino Fundamental. Brasília: MEC/SEF, 1998

BRASIL. Secretaria de Educação Média e Tecnológica. Parâmetros Curriculares Nacionais: Ensino Médio - Parte IV - Ciências Humanas e suas Tecnologias. Brasília: MEC/SEMTEC, 2000. p. 29-35.

BRASIL. Secretaria de Educação Média e Tecnológica. PCN+Ensino Médio: Orientações Educacionais complementares aos Parâmetros Curriculares Nacionais - Ciências Humanas e suas Tecnologias. Brasília: MEC/SEMTEC, 2002. p. 55-68. 
BRASIL. Ministério da Saúde. Secretaria de Gestão do Trabalho e da Educação na Saúde. Departamento de Gestão da Educação na Saúde. A educação permanente entra na roda. Brasília: Ministério da Saúde, 2005a.

BRASIL. Ministério da Saúde. Secretaria de Gestão do Trabalho e da Educação na Saúde. Departamento de Gestão da Educação na Saúde. Curso de facilitadores de educação permanente em saúde: unidade de aprendizagem - Práticas educativas no cotidiano do trabalho em saúde. Brasília: Ministério da Saúde, 2005b.

BRAVERMAN, Harry. A Revolução técnico-científica e o trabalhador. In: Trabalho e capital monopolista: a degradação do trabalho no século XX. Tradução de Nathaniel C. Caixeiro. Rio de Janeiro: Zahar Editores, 1997.

CANDAU, Vera Maria. Direitos humanos, educação e interculturalidade: as tensões entre igualdade e diferença. Rev. Bras. Educ., Abr 2008, vol.13, no.37, p.45-56. ISSN 1413-2478

CANEN, Ana e OLIVEIRA, Angela M. A. de. Multiculturalismo e currículo em ação: um estudo de caso. Rev. Bras. Educ., Dez 2002, no.21, p.61-74. ISSN 1413-2478

CASIMIRO, Ana Palmira Bittencourt Santos. Pensamentos Fundadores na Educação Religiosa do Brasil Colônia. 2006. Acesso em: 20/01/2010. Disponível em: http://www.histedbr.fae.unicamp.br/navegando/artigos_frames/artigo_006.html

CASTELLAR, Sonia (Org.). Educação geográfica: teorias e práticas docentes. São Paulo: Contexto, 2006.

CARLOS, Ana Fani Alessandri (Org.). Novos caminhos da Geografia. São Paulo: Contexto, 2001.

CALLAI, Helena Copetti. A geografia e a escola: muda a Geografia? Muda o ensino? In: Terra Livre $\mathrm{n}^{\circ} 16$ - Paradigmas da Geografia - Parte I. São Paulo: AGB, 2001. p. 133-152

CARBONE, Maria Herminda. Tísica e rua: os dados da vida e seu jogo. [Mestrado]. Fundação Oswaldo Cruz, Escola Nacional de Saúde Pública, 2000. 106p.

CLAVAL, P. Espaço e Poder. Rio de Janeiro: Zahar, 1979.

CORRÊA, Roberto Lobato. Região e Organização Espacial. São Paulo: Ática, 1986.

COUTINHO, Luciano. A terceira revolução industrial e tecnológica: as grandes tendências de mudança. In: Economia e Sociedade. Revista do Instituto de Economia da UNICAMP. Campinas, n.1, 1992.

DEVELTERE, P. et FONTENEAU, B. Société civile, ONG, tiers secteur, mouvement social et économie sociale: conception du Nord, pertinence au Sud? Cahier de la Chaire de recherche du Canadá en développement des collectivités (CRDC), Université du Québec em Outaouais:, série Recherche no. 29, décembre/2002.

DUPRET, Lúcia Maria (Org.). Possibilidades da educação à distância: o desfio de requalificar os agentes locais de vigilância em saúde da Fundação Nacional de Saúde. Programa de Formação de Agentes Locais em Vigilância em Saúde - PROFORMAR. Escola Politécnica de Saúde Joaquim Venâncio - EPSJV/FIOCRUZ. Disponível em: http://espacio.uned.es/fez/eserv.php?pid=bibliuned:1102\&dsID=n09dupret01.pdf. 
DUVAL, Guy. Saúde e Ambiente no Processo de Desenvolvimento. Ciência e Saúde Coletiva, vol3, $\mathrm{n}^{\circ} 2,1998$.

FALL, Abdou Salam et GUÈYE, Chekh. Derem ak ngerem Le franc, la grace et la reconnaissance. Lês ressorts d'une économie sociale et solidaire em Afrique de l'Ouest. Cahier de la Chaire de recherche du Canadá en développement des collectivités (CRDC),Université du Québec em Outaouais:, série Recherche no. 26, 2002.

FARREL, Jeanetti. A Assustadora História das Pestes e Epidemias. São Paulo: Ediouro, 2003.

FAVREAU, Louis et FRÉCHETTE, Lucie. Économie sociale, coopération Nord/Sud et développement. Cahier de la Chaire de recherche du Canadá en développement des collectivités (CRDC),Université du Québec em Outaouais:, série Recherche no. 14, 1999.

Développement local et économie populaire em Amérique Latine: l'expérience de Villa El Salvador. Cahier de la Chaire de recherche du Canadá en développement des collectivités (CRDC),Université du Québec em Outaouais:, série Recherche no. 1, mai/2002.

FORRESTER, V. O horror econômico. São Paulo: Editora UNESP, 1997.

FOUCAULT, Michel. Microfísica do Poder. Rio de Janeiro: Graal, 1979.

FRANCO, Maria Amélia Santoro. Pedagogia da pesquisa-ação. Educação e Pesquisa, São Paulo, v.31, n.3, p.483-502, set./dez. 2005. Disponível em: http://www.scielo.br Acesso em: agosto/2008.

FREIRE, Paulo. Cartas a Guiné-bissau: registros de uma experiência em processo. Rio de Janeiro: Paz e Terra, 1980.

. Pedagogia da Esperança. São Paulo: Editora Paz e Terra, 1992.

Terra, 1996.

Pedagogia da Autonomia: saberes necessários à prática educativa. São Paulo: Paz e . Educação e Atualidade Brasileira. São Paulo: Cortez, Inst. Paulo Freire, 2001.

. Educação e Mudança. São Paulo: Paz e Terra, 2001b.

. FREIRE, P. Sobre educação popular: Entrevista com Paulo Freire.In: TORRES, R.M. (org). Educação popular: um encontro com Paulo Freire. 2 ed. São Paulo: Edições Loyola, 2002.

. Pedagogia da tolerância. São Paulo: UNESP, 2004.

. Pedagogia do Oprimido. São Paulo, Paz e Terra, 2005.

. Ação Cultural para a Liberdade e outros escritos. São Paulo, Paz e Terra, 2007.

FREITAS, Carlos. Problemas Ambientais, Saúde Coletiva e Ciências Sociais. Ciência e Saúde Coletiva, vol 8, n 1, 2003. 
FURLANETTI, Maria Peregrina de Fátima Rotta. Compartilhando Experiências: Dialogando com a prática da alfabetização. Bauru, SP, Canal6, 2009.

GENTILI, Pablo (org.). Pedagogia da Exclusão. Petrópolis: Vozes, 2001.

GHEDIN, E. e Pimenta, S. G. (orgs.). Professor Reflexivo no Brasil: Gênese e Crítica de um Conceito. São Paulo: Cortez, 2002.

GHON, Maria da Glória. Educação Não-Formal e Cultura Política - impactos sobre o associativismo do terceiro setor. São Paulo: Cortez, 1999.

GOMES, P. C. da C.; CORRÊA, R. L. Geografia: conceitos e temas. Rio de Janeiro: Bertrand Brasil, 2003.

GONÇALVES, Luiz Alberto Oliveira e SILVA, Petronilha Beatriz Gonçalves e. Movimento Negro e Educação. Rev. Bras. Ed., Nov.- Dez. 2000, n. 15, p. 134- 158.

GONÇALVES, Luiz Alberto Oliveira e SILVA, Petronilha Beatriz Gonçalves e. Multiculturalismo e educação: do protesto de rua a propostas e políticas. Educ. Pesqui., Jun 2003, vol.29, no.1, p.109-123. ISSN 1517-9702

GONÇALVES, L. A. O.; SILVA, P. B. G. O jogo das diferenças: o multiculturalismo e seus contextos. Belo Horizonte: Autêntica, 2001.

GONÇALVES, Mauro. A Dimensão Ambiental na Educação. Campinas: Papirus, 2000.

GREENPEACE. A Possível revolução Energética. Disponível em :http://diplo.uol.com.br/200704,a1556. Acessado em : 09/04/2008.

GRYNSZPAN, Danielle. Educação em saúde e educação ambiental: uma experiência integradora. Cad. Saúde Pública, v.15 supl. 2, p.133- 138, 1999. Disponível em: http://www.scielo.br Acesso em: agosto/2008.

GUIMARÃES, R. B. Regiões de Saúde e Escalas Geográficas. Cadernos de Saúde Pública, vol 21, $\mathrm{n}^{\circ}$ 4, 2005.

HAESBAERT, Rogério. Morte e Vida da Região: Antigos Paradigmas e Novas Perspectivas da Geografia Regional. In: Sposito, Eliseu S. (org.). Produção do Espaço e Redefinições Regionais: Construção de uma Temática. Presidente Prudente: UNESP/GASPERR.

Territórios Alternativos. São Paulo: Contexto: 2006.

HARVEY, David. Condição pós-moderna. Uma pesquisa sobre as origens da mudança cultural. São Paulo, Loyola, 1992.

HIRATA, H. e Zarifian, P. Força e Fragilidade do Modelo Japonês. In: Estudos Avançados, 12(5), 1991.

HOBSBAWM, Eric. Do feudalismo para o capitalismo. In: A transição do feudalismo para o capitalismo. Por Paul Sweezy e outros. Tradução de Isabel Didonnet. Rio de Janeiro, Paz e Terra, 1977. 
IKUTA, F. K. A questão da moradia para além de quatro paredes: uma reflexão sobre a fragmentação dos movimentos sociais da produção e da reprodução em Presidente Prudente/SP. Dissertação (Mestrado em Geografia). Presidente Prudente: FCT/UNESP, 2003.

LAFARGUE, P. O direito à preguiça. São Paulo: Hucitec, UNESP, 1999.

LANDIM, F. L. P. et al. Uma reflexão sobre as abordagens em pesquisa com ênfase na integração qualitativo - quantitativa. Rev. Bras. Em Prom. Da Saúde, v. 19, n. 1, p. 53- 58, 2006. Disponível em: http://www.scielo.br Acesso em: agosto/2008.

LEFEBVRE, Henry. O direito à cidade. São Paulo: Centauro, 2001.

LEMOS, J. C.; LIMA, S. do C. A Geografia Médica e as Doenças Infecto-Parasitárias. Caminhos da Geografia, v. 3 n. 6, jun/2002.

LUCKESI, C.C. Filosofia da educação. São Paulo: Cortez, 1994.

MACIÀ ANTÓN, Diego. Drogas: Conhecer e Educar para Prevenir. São Paulo: Scipione, 2000.

MAIA, Doralice Sátyro. A Geografia e o estudo dos costumes e das tradições. In: Terra Livre $\mathrm{n}^{\circ} 16$ Paradigmas da Geografia - Parte I. São Paulo: AGB, 2001. p. 71-98

MARICONI, F. de A. M. et al. A mosca doméstica e algumas outras moscas nocivas. Piracicaba: FEALQ, 1999.

MARQUES, E. C. Os modelos espaciais como instrumento para o estudo de fenômenos urbanos. In: Najar, A. L. e Marques, E. C. (orgs.). Saúde e Espaço: Estudos Metodológicos e Técnicas de Análise. Rio de Janeiro: Ed. Fiocruz, 1998.

MELO, Beatriz Medeiros. Migração. Memória e Território: O trabalhador Rural Nordestino na Ibaté Paulista. Dissertação (Mestrado em Geografia). Presidente Prudente: FCT/UNESP, 2008.

MENDONÇA, Fernanda de Freitas. Formação de facilitadores de educação permanente em saúde: Percepções de tutores e facilitadores. Londrina, Paraná. 2007. 124f. Dissertação (Mestrado em Saúde Coletiva) - Universidade Estadual de Londrina.

MÉSZÁROS, István. A Educação para além do capital. Trad. De Isa Tavares. São Paulo: Boitempo, 2005.

MINAYO, Maria Cecilia de S. e SANCHES, Odécio. Quantitativo-qualitativo: oposição ou complementaridade? Cad. Saúde Pública, vol.9, n.3, p.237-248, Jul/Set. 1993. Disponível em: http://www.scielo.br Acesso em: agosto/2008.

MOREIRA, Antonio Flavio Barbosa e CANDAU, Vera Maria. Educação escolar e cultura(s): construindo caminhos. Rev. Bras. Educ., Ago 2003, no.23, p.156-168. ISSN 1413-2478

MORIN, Edgar. Part. De Marcos Terena. Saberes Globais e Saberes Locais: o olhar transdisciplinar. Rio de Janeiro: Garamond, 2008. 
MOROSINI, Márcia Valéria et al. O Agente Comunitário de Saúde no Âmbito das Políticas Voltadas para a Atenção Básica: Concepções do Trabalho e da Formação Profissional. Trabalho, Educação e Saúde, v. 5 n. 2, p. 261-280, 2007.

MOTA, Suetônio. Urbanização e Meio Ambiente. Rio de Janeiro: ABES, 1999.

NEVES, J. L. Pesquisa Qualitativa - Características, Usos e Possibilidades. Cad. De Pesq. em Adm., São Paulo, v. 1, n. 3, $2^{\circ}$ SEM./ 1996. Disponível em: http://www.scielo.br Acesso em: agosto/2008.

O’DWYER, G.; TAVARES, M.F.L.; DE SETA, M.H. O desafio de operacionalizar as ações de vigilância sanitária no âmbito da promoção da saúde e no locus saúde da família. Interface - Comunic., Saúde, Educ., v.11, n.23, p.467-84, set/dez 2007.

OLIVEIRA, Leandro Dias de . A Construção do "Desenvolvimento Sustentável" sob a Égide do Neoliberalismo: Um Estudo sobre a Economia Política da "Crise Ambiental". In: 5. ${ }^{\circ}$ Colóquio Internacional Marx e Engels, 2007, Campinas. Comunicações. Campinas : UNICAMP, 2007

OLIVEIRA, Maria Waldenez de. Processos Educativos em Trabalhos Desenvolvidos entre Comunidades: Perspectivas de Diálogo entre Saberes e Sujeitos. Pesquisa realizada como parte das atividades de pós-doutorado efetuado junto a Fundação Oswaldo Cruz FIOCRUZ, Rio de Janeiro: 2003.

PELICIONI, M.C.F. Educação Ambiental para uma Escola Saudável. In: Phillipi Jr., A; Pelicioni, M.C.F. (eds.). Educação Ambiental e Sustentabilidade. Barueri, SP: Manole, 2005.

Promoção da Saúde e meio Ambiente: Uma Trajetória Técnico-Política. In: Phillipi Jr., A; Pelicioni, M.C.F. (eds.). Educação Ambiental e Sustentabilidade. Barueri, SP: Manole, 2005.

PEREIRA, M. P. B. Conhecimento geográfico do agente de saúde: competências e práticas sociais de promoção e vigilância à saúde na cidade do Recife - PE. Tese (Doutorado em Geografia). Presidente Prudente: FCT/UNESP, 2008.

PILETTI, Nelson. História da Educação no Brasil. São Paulo: Ática, 1991.

PIMENTA, S. G. Pesquisa-ação crítico-colaborativa: construindo seu significado a partir de experiências com a formação docente. Educação e Pesquisa, São Paulo, v. 31, n. 3, p. 521539, set/dez 2005. Disponível em: http://www.scielo.br Acesso em: agosto/2008.

RIGOTTO, R. M. e Augusto, L. G. da S. Saúde e ambiente no Brasil: desenvolvimento, território e iniqüidade social. Cad. de Saúde Pública, 2007, vol. 23 supl. 4, p. S475 - S485.

SANTOS, A. M. M. dos. Gerenciamento Ambiental para Controle de Musca Domestica L. Diptera: Muscidae) e Chrysomya Megacephala (Fabricius) (Diptera: Calliphoridae) em Assentamentos Urbanos Paulistas. Tese de Doutorado, Campinas: UNICAMP, 2006.

SANTOS, B. S. A construção multicultural da igualdade e da diferença. (Oficina do CES n. 135), Coimbra Centro de Estudos Sociais, 1999. 
SANTOS, L. A. de Castro, FARIA, Lina. O Ensino da Saúde Pública no Brasil: Os Primeiros Tempos no Rio de Janeiro. Trabalho, Educação e Saúde, v. 4, n. 2, p. 291 - 324, 2006.

SANTOS, Milton. Espaço e Método. São Paulo, Nobel, 1985.

A Urbanização Brasileira. São Paulo, Hucitec, 1993.

A natureza do espaço: técnica e tempo, razão e emoção. São Paulo: Hucitec, 1997.

Metamorfoses do espaço habitado. São Paulo: Hucitec, 1998.

Saúde e Ambiente no Processo de Desenvolvimento. Ciência e Saúde Coletiva, 8 (1), $309-314,2003$.

SÃO PAULO. Secretaria de Estado da Educação. Proposta Curricular do Estado de São Paulo: Geografia. São Paulo: SEE, 2008.

SAVIANI, Dermeval. História das idéias pedagógicas no Brasil. Campinas: Autores Associados, 2007. 473p.

SECRETARIA DE POLITICAS DE SAUDE. Departamento de Atenção Básica. Programa Saúde da Família. Rev. Saúde Pública [online]. 2000, vol.34, n.3, pp. 316-319. ISSN 0034-8910.

SEOLIN DIAS, L. Biodiversidade de Mosca Calliphoridae e Muscidae no Depósito de Lixo Urbano de Presidente Prudente, São Paulo, Brasil. Dissertação (Mestrado em Ciência Animal), Universidade do Oeste Paulista - UNOESTE: Presidente Prudente, SP, 2008.

SEOLIN DIAS, L. e GUIMARÃES, R. B. Freqüência de moscas no Jardim Morada do Sol, no município de Presidente Prudente, SÃO PAULO, BRASIL. Encontro de Ensino, Pesquisa e Extensão da UNOESTE - ENEPE, 2008.

SEMPRINI, A. Multiculturalismo. Trad. Laureano Pelegrin. Bauru, SP: EDUSC, 1999.

SILVA, J. P. V. da; Tavares,, C. M. de M. Integralidade: Dispositivo para a Formação Crítica de Profissionais de Saúde. Trabalho, Educação e Saúde, v.2 n.2, p.271-285, 2004.

SILVA, Valéria Cristina Pereira da. Girassóis de Pedra: imagens e metáforas de uma cidade em busca do tempo. Tese (Doutorado em Geografia). Universidade Estadual Paulista/Faculdade de Ciências e Tecnologia, Presidente Prudente, SP, 2008.

SILVERIO, Maria Regina e PATRICIO, Zuleica Maria. O processo qualitativo de pesquisa mediando a transformação da realidade: uma contribuição para o trabalho de equipe em educação em saúde. Ciênc. saúde coletiva, v.12, n.1, p.239-246, jan./mar. 2007. Disponível em: http://www.scielo.br Acesso em: agosto/2008.

STOTZ, Eduardo Navarro. A cultura e o saber: linhas cruzadas, pontos de fuga. Interface Comunic., Saúde, Ed., n. 8, p. 132-134, 2001. Disponível em: http://www.interface.org.br Acesso em: agosto/2008.

A Educação Popular nos Movimentos Sociais da Saúde: Uma Análise de Experiências nas Décadas de 1970 e 1980. Trabalho, Educação e Saúde, v. 3 n. 1, p. 9-30, 2005. 
SUERTEGARAY, D. M. A. Espaço geográfico uno e múltiplo. In: SUERTEGARAY, D. M. A.; BASSO, L. A.; VERDUM, R. Ambiente e lugar no urbano: a grande Porto Alegre. Porto Alegre: Ed. da UFRGS, 2000. 239 p.

SUERTEGARAY, D. M. A.; NUNES, J. O. R. A natureza da Geografia Física na Geografia. In: Revista Terra Livre - Paradigmas da Geografia - Parte II. São Paulo: AGB, 2001. N 17. p. 11-24.

TAMBELini, A. A temática Saúde e Ambiente no Processo de Desenvolvimento do Campo da Saúde Coletiva. Ciência e Saúde Coletiva, vol. 3, nº 2, 1998.

TELAROLI JR., Rodolpho. Epidemias no Brasil: Uma Abordagem Biológica e Social. São Paulo: Moderna, 1995.

THIOLLENT, Michel. Metodologia da Pesquisa-Ação. São Paulo: Cortez, 1988.

THRIFT, N. Visando o Âmago da Região. In: Gregory, D. et all. Geografia humana. Rio de Janeiro: Zahar, 1982.

VAILLANCOURT, Yves et FAVREAU, Louis. Le modèle québecois d'économie sociale et solidaire. Cahier de la Chaire de recherche du Canadá en développement des collectivités (CRDC),Université du Québec à Hull:, série Recherche no. 18, mai/2000.

VALLA, V.V. Educação popular, saúde comunitária e apoio social numa conjuntura de globalização. Cad. Saúde Pública, n.15, supl.2, p.7-14, 1999. Disponível em: http://www.scielo.br Acesso em: agosto/2008.

VASCONCELOS, E. M. Redefinindo as práticas de saúde a partir de experiências de educação popular nos serviços de saúde. Interface - Comunic., Saúde, Educ., v.5, n.8, p.121-6, 2001. Disponível em: http://www.interface.org.br Acesso em: agosto/2008.

VASCONCELOS, E. M. Educação popular, um jeito especial de conduzir o processo educativo no setor saúde. Disponível em: <www.redepopsaude.com.br>. Acesso em: 2 jan. 2005.

VASCONCELOS, E. M. Educação popular e pesquisa-ação como instrumentos de reorientação da prática médica. In: Brennand Edna GG (Org.). O Labirinto da Educação Popular. 1 ed. João Pessoa, p 189-208, 2003. 
ANEXOS 
ANEXO 1 
Questionário para diagnóstico da qualidade de saúde ambiental dos moradores dos bairros Jardim Morada do Sol e Residencial Francisco Belo Galindo.

Governança Local - Casa da Sopa, Senac, Associação de Moradores, PSF, CRAS, Pastoral da Criança, Equipe de Bethânia, EMEIF, PROAMA,Unesp.

\section{1-APRESENTAÇÃO.}

1. INFORMAÇÕES GERAIS

\begin{tabular}{|l|l|l|l|}
\hline entrevistador & $\begin{array}{l}\text { data da } \\
\text { entrevista }\end{array}$ & $\begin{array}{l}\text { horário } \\
\text { da entrevista }\end{array}$ & $\mathbf{n}^{\circ}$. do quest.: \\
\hline
\end{tabular}

2. DADOS GERAIS DO DOMICÍLIO

\begin{tabular}{|l|l|l}
\hline a) município & b) bairro & nº do lote / localização na planta \\
Presidente Prudente/SP & & \\
\hline endereço
\end{tabular}

3. DADOS GERAIS DO ENTREVISTADO

\begin{tabular}{|l|l|l|l|}
\hline \multicolumn{2}{|l|}{} & a) sexo do entrevistado & b) idade do entrevistado \\
\hline c) grau de parentesco com o chefe de família & contato &
\end{tabular}

4-Informar na tabela abaixo, o número de pessoas residentes no domicílio, a idade e a escolaridade de cada um dos residentes:

\begin{tabular}{|c|c|c|c|c|c|c|c|c|c|c|}
\hline \multicolumn{2}{|l|}{ Pessoas } & \multicolumn{7}{|c|}{ Nível de escolaridade } & \multicolumn{2}{|c|}{$\begin{array}{l}\text { Freqüenta a } \\
\text { Escola? }\end{array}$} \\
\hline Nome/ Grau de parentesco & Idade & AN & FI & FC & MI & MC & SI & sc sit & Sim & Não \\
\hline $1-$ & & & & & & & & & & \\
\hline 2- & & & & & & & & & & \\
\hline $3-$ & & & & & & & & & & \\
\hline $4-$ & & & & & & & & & & \\
\hline $5-$ & & & & & & & & & & \\
\hline 6- & & & & & & & & & & \\
\hline $7-$ & & & & & & & & & & \\
\hline 8- & & & & & & & & & & \\
\hline $9-$ & & & & & & & & & & \\
\hline $10-$ & & & & & & & & & & \\
\hline $11-$ & & & & & & & & & & \\
\hline $12-$ & & & & & & & & & & \\
\hline 13- & & & & & & & & & & \\
\hline $14-$ & & & & & & & & & & \\
\hline $15-$ & & & & & & & & & & \\
\hline
\end{tabular}
AN- Analfabeto
FC- Fundamental completo
MC- Médio Completo
SC- Superior Completo

FI- Fundamental Incompleto

MI- Médio Incompleto

SI- Superior Incompleto

SIE- Sem Idade Escolar

\section{2-INTRODUÇÃO.}

2.1- Qual a sua opinião sobre o que afeta negativamente a sua saúde e a dos residentes neste domicílio? 
2.2- Qual a sua opinião sobre o que pode ser feito para melhorar a sua saúde e a dos residentes neste domicílio?

3-RELAÇÃO AMBIENTE/SAÚDE.

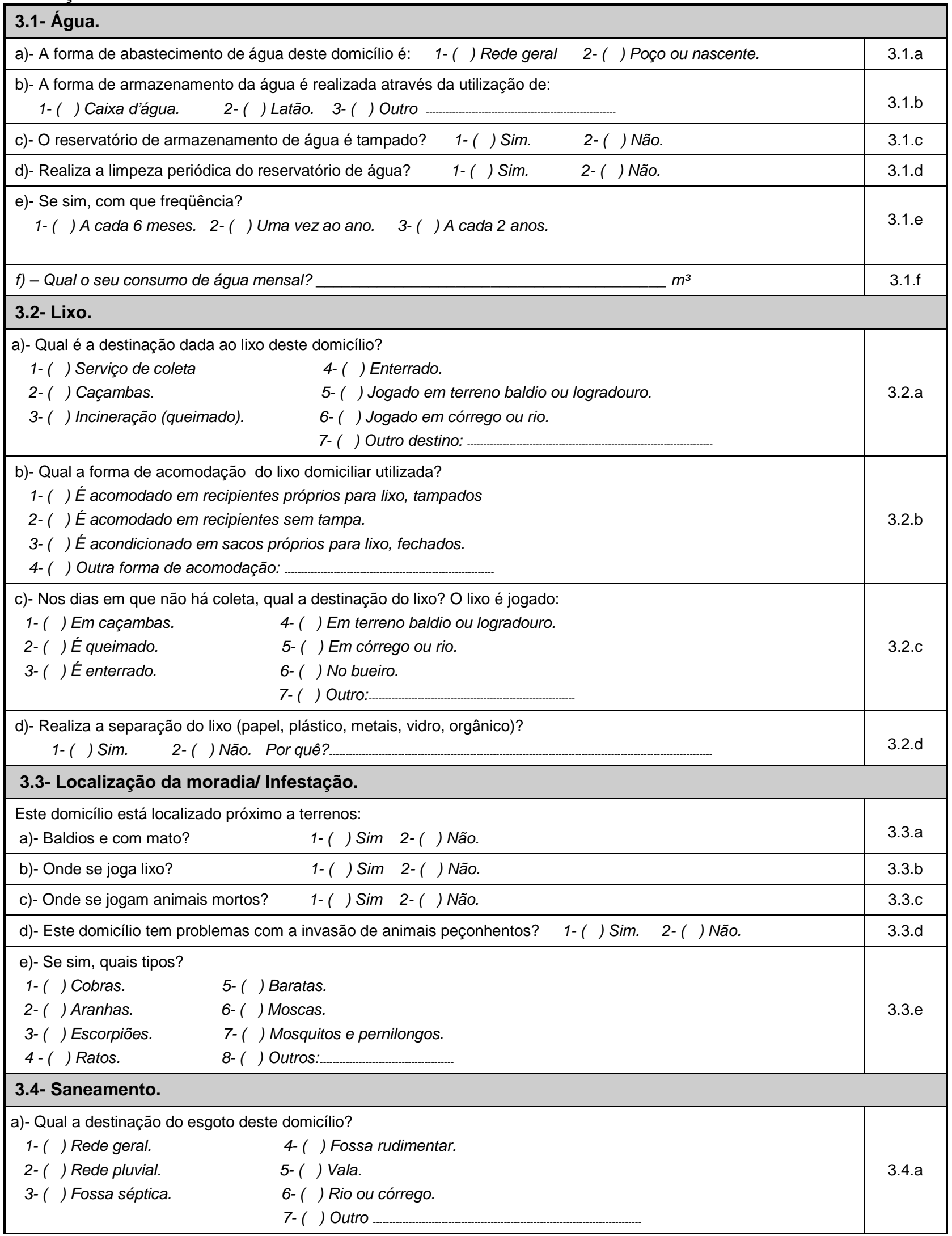




\section{5- Drenagem.}

a)- O domicílio foi inundado por água de chuva ou enchente nos últimos cinco anos?

1- ( ) Sim 2-( ) Não. 3- ( ) Não sabe. 4- Se sim, com que freqüência?

b)- A rua deste domicílio possui sistema de drenagem (bueiros)?

1-( ) Sim

2- ( ) Não.

3- ( ) Não

c)- A rua deste domicílio sofre alagamento? 1- ( ) Sim ( ) Não. 3- ( ) Não sabe.

\section{4-RELAÇÃO HIGIENE/SAÚDE.}

\section{1-Animais.}

a)- Possui animais de estimação e /ou criação?

$$
\text { 1-( ) } \operatorname{Sim} \text { 2-( ) Não. }
$$

b)- Qual a quantidade existente neste domicílio de:

\begin{tabular}{|c|c|c|}
\hline 1- Cachorro & ) & 5- Porco \\
\hline 2- Gato & ) & 6- Cabra \\
\hline 3- Passarinho & ) & 7- Coelho \\
\hline 4- Galinha & ) & 8- Vaca \\
\hline & & 9- Outro \\
\hline
\end{tabular}

c)- De que forma é realizada a limpeza dos locais onde vivem os animais?

1- ( ) Os locais são varridos e lavados.

4- ( ) Os locais são apenas lavados.

2-( ) Os locais são varridos, lavados e desinfetados.

5- ( ) Não é feita a limpeza.

3- ( ) Os locais são apenas varridos.

6- ( ) Outro

d)- Com que freqüência é feita a limpeza dos locais onde vivem os animais?
1-( ) Diariamente.
4- ( ) Uma vez por semana.
2-( ) Dia sim, dia não.
5- ( ) Uma vez por mês.

3- ( ) Uma vez a cada três dias.

\begin{tabular}{l}
\hline e)- É feita a vacinação anual destes animais? $1-($ ) $\operatorname{Sim} . \quad$ 2- ( ) Não. \\
\hline f)- É feita a vermifugação periódica destes animais? $1-($ ) $\operatorname{Sim}$.
\end{tabular}

g)- De que forma é realizada a limpeza dos dejetos (fezes e urina) dos animais?

h) Algum animal apresentou problemas de saúde (sarna, pulgas, etc) no último mês?
1-( ) Sim.
2-( ) Não.
3- Se sim, qual?

\section{2- Alimentos.}

a)- Tem o hábito de cobrir os alimentos que ficam fora da geladeira?

$$
\text { 1-（ ) Sim. 2-( ) Não. }
$$

b)- Da última vez que sobrou comida do almoço, o que você fez?

1- ( ) Guardei imediatamente na geladeira.

2- ( ) Deixei esfriando para depois guardar na geladeira.

3- ( ) Deixei fora da geladeira.

c)- Quando mexe com carne crua, que cuidado toma com as mãos antes e depois do preparo?
1-( ) Nenhum
2-( ) Limpa com um pano.
3- ( ) Passa na água.
4- ( ) Lava bem com água e sabão.

\section{3- Higiene pessoal e da casa.}

a)- Realiza o controle de piolhos nas crianças?

$$
\text { 1-（） Sim. 2-( ) Não. }
$$

b)- Faz a manutenção da limpeza e corte das unhas das crianças?

$$
\text { 1-( ) Sim. 2-( ) Não. }
$$

c)- Costuma lavar semanalmente as roupas de cama e banho? 
d)- O quintal é mantido limpo, retirando-se as folhas e entulhos?

1-( ) Sim. 2-( ) Não.

5- DOENÇAS.

5.1- Doenças de pele e olhos.

a)- Houve casos de doenças de pele (no corpo e na cabeça) neste domicílio nos últimos três meses?

1-( ) Sim. 2-( ) Não.

b)- Se sim, especificar a quantidade e a idade das pessoas afetadas:

c)- Houve casos de sarna neste domicílio nos últimos três meses?

1-( ) Sim. 2-( ) Não.

d)- Se sim, especificar a quantidade e a idade das pessoas afetadas:

$--$

e)- Houve casos de "bicho geográfico" neste domicílio nos últimos três meses?

1-( ) Sim. 2-（）Não.

f)- Se sim, especificar a quantidade e a idade das pessoas afetadas:

$---$

g) Houve casos de piolhos neste domicílio nos últimos três meses?

1-( ) Sim. 2-( ) Não.

h)- Se sim, especificar a quantidade e a idade das pessoas afetadas:

i)- Houve casos de conjuntivite neste domicílio nos últimos três meses?

1-（） Sim. 2-（）Não.

j)- Se sim, especificar a quantidade e a idade das pessoas afetadas:

\subsection{Diarréias.}

a)- Houve casos de diarréia neste domicílio nos últimos três meses?

1-（ ) Sim. 2-（）Não.

b)- Se sim, especificar a quantidade e a idade das pessoas afetadas:

c) Houve casos de virose neste domicílio nos últimos três meses?

1-（） Sim. 2-（） Não.

d)- Se sim, especificar a quantidade e a idade das pessoas afetadas:

5.3- Verminoses.

a)- Houve casos de vermes neste domicílio nos últimos três meses?

1-( ) Sim. 2-( ) Não.

b)- Se sim, especificar a quantidade e a idade das pessoas afetadas: 
6-ORGANIZAÇÃO POPULAR.

\section{1- Utilidade.}

a) Você utiliza qual serviço em seu bairro?

( ) PSF ( ) Casa da Sopa

( ) CRAS

( ) Escola

( ) PROAMA

( ) Outro

b)- Quais tipos de serviços busca nestas entidades?

\section{ANOTAÇÕES/OBSERVAÇÕES FINAIS}

Comentários adicionais do entrevistado

-

-

Termo de consentimento - Assinatura do entrevistado e data: 
ANEXO 2 


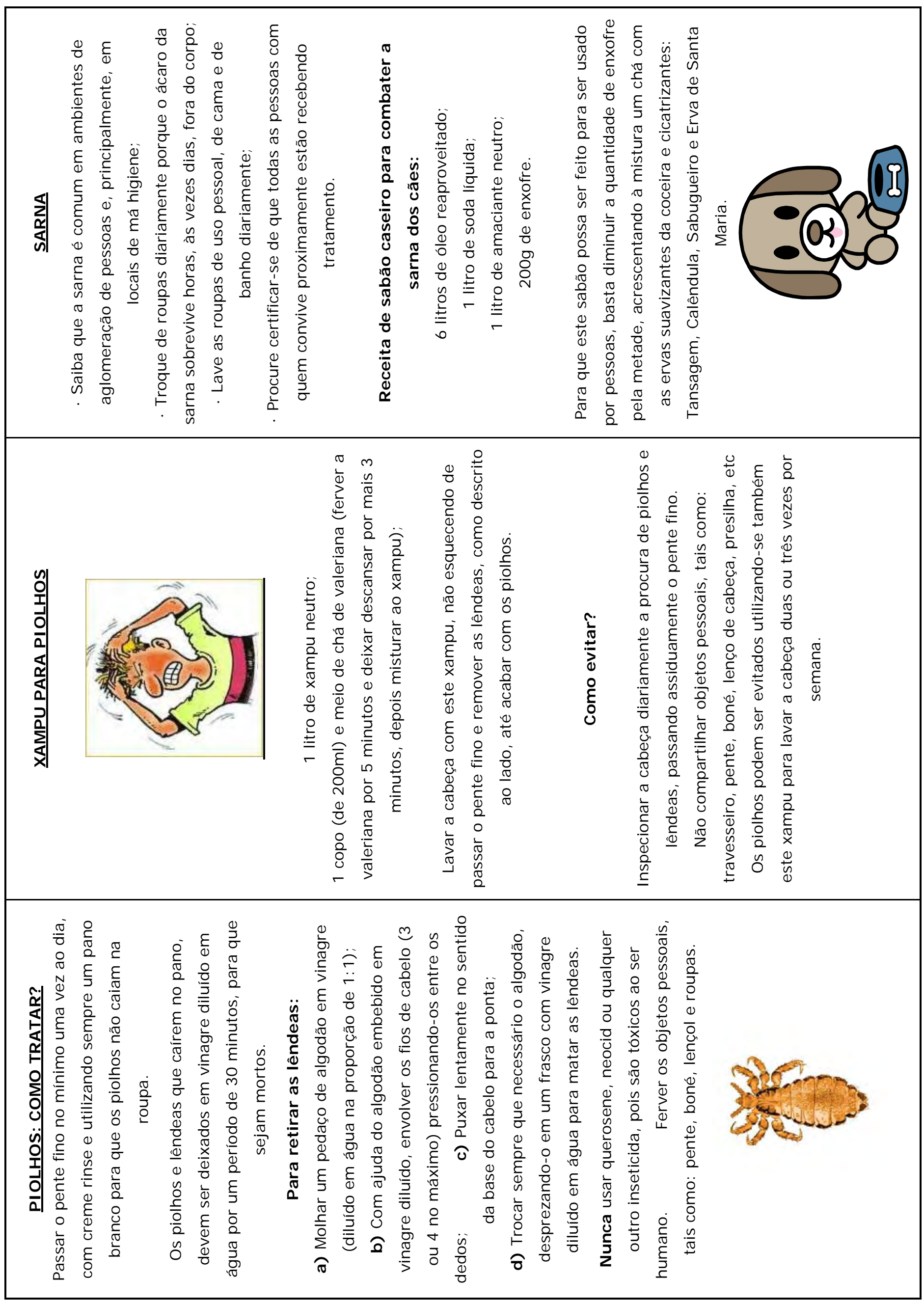




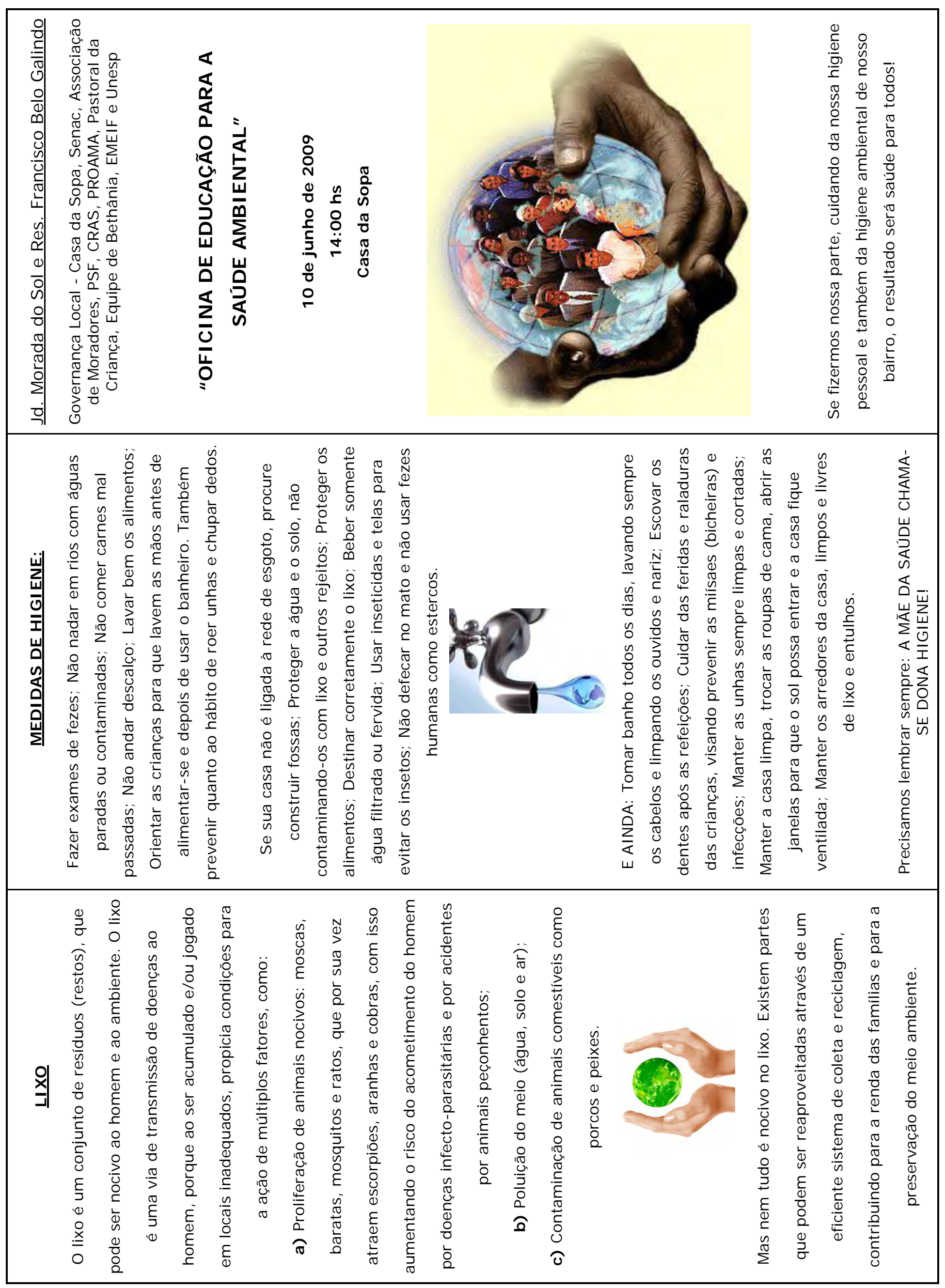


ANEXO 3 


\section{Valeriana (Valeriana officinalis)}

Amantila, bardo selvagem, erva gata, valaricana ou badarina

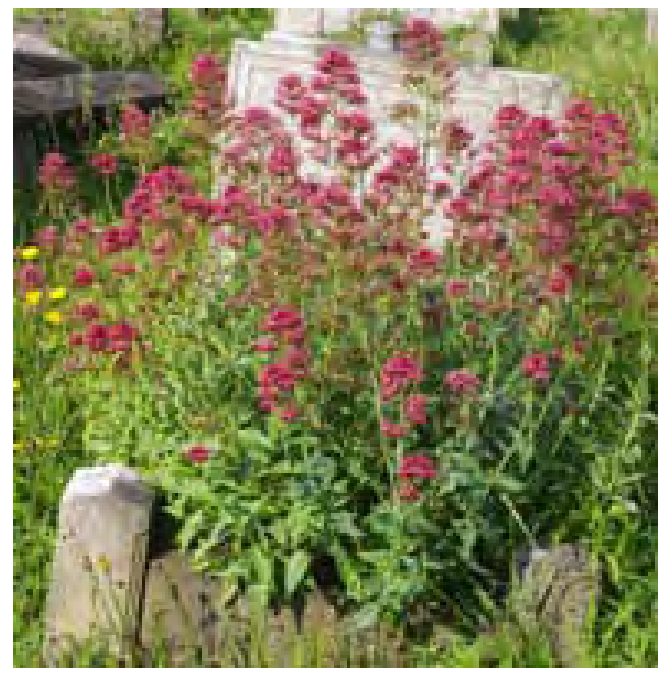

\section{Descrição}

Valeriana é uma planta perene, sendo bastante resistente a condições climáticas adversas, podendo atingir entre 1 e 1,5 metros de altura. Encontrada nativamente na Europa e região norte da Ásia, e regiões de clima temperado. Suas flores são pequenas e numerosas, de coloração branca ou rosada e roxa, que exalam forte aroma adocicado e peculiar. As partes utilizadas para fins terapêuticos são sua raíz e rizoma. Curiosamente, os gatos e os ratos se sentem muito atraídos pela raíz de Valeriana, tanto é que era utilizada como isca em armadilhas para ratos.

\section{I ndicações}

A Valeriana é principalmente indicada para problemas de insônia, para melhoria da qualidade do sono. Possui efeito tranquilizante, sedativo, relaxante, reduz a pressão sangüínea, combate problemas de ansiedade, estresse e palpitações cardíacas de origem nervosa. Estudos científicos comprovam a eficácia da Valeriana no tratamento da insônia e diminuição da ansiedade. 
ANEXO 4 


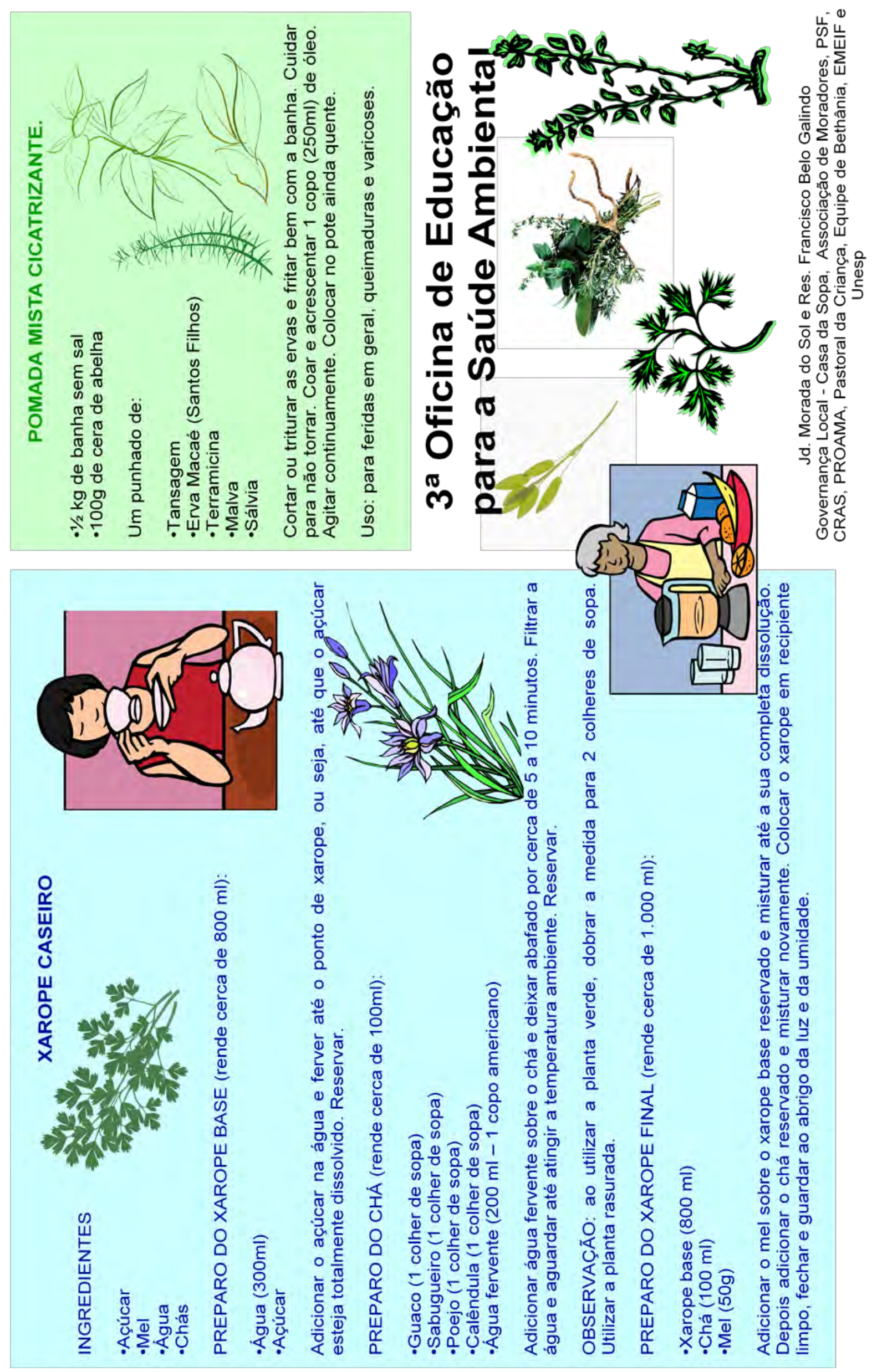

